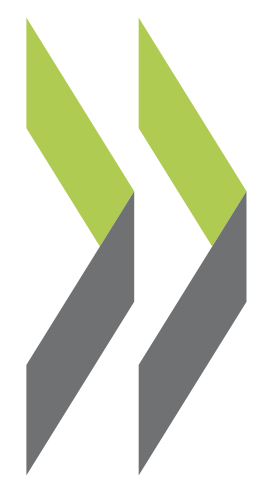

OECD Economics Department Working Papers No. 427

The Impact of Structural Policies on Trade-Related Adjustment and the Shift

to Services

\section{Per Mathis Kongsrud,}


ECONOMICS DEPARTMENT

THE IMPACT OF STRUCTURAL POLICIES ON TRADE-RELATED ADJUSTMENT AND THE SHIFT TO SERVICES

ECONOMICS DEPARTMENT WORKING PAPERS No. 427

By Per Mathis Kongsrud and Isabelle Wanner

All Economics Department Working Papers are now available through the OECD Internet Web site at www.oecd.org/eco 


\section{ABSTRACT/RÉSUMÉ}

\section{The impact of structural policies on trade-related adjustment and the shift to services}

What policy reforms are most urgently needed to remove obstacles to output and employment growth in service sectors and to enhance economies' ability to adjust to structural change as a result of changing trade patterns? This paper reviews the impact of the structural policy framework conditions on the development of the service sector and economies' adjustment capacities. The paper builds on and summarises a vast body of previous work and briefly reviews policy recommendations given to countries in various surveillance processes in the OECD.

JEL codes: F16, F4, J6

Keywords: structural policies, regulation, international trade, service sector developments, labour mobility

******

Les effets des politiques structurelles sur l'ajustement relatif aux échanges et au changement dans le secteur de services

Quelles sont les réformes les plus urgentes pour remédier aux obstacles à la croissance de la production et de l'emploi dans les services et pour faire en sorte que les économies soient mieux à même de s'ajuster au changement structurel résultant de l'évolution des profils d'échanges? Ce document fait le point sur l'impact de la politique structurelle dans le développement du secteur des services et de la capacité d'ajustement des économies. Il s'appuie sur un grand nombre de travaux antérieurs dont il fait la synthèse et résume brièvement les recommandations formulées à l'intention des pays dans le cadre des divers mécanismes de surveillance à l'OCDE.

Classification JEL: F16, F4, J6

Mots clés: politiques structurelles, réglementation, commerce international, développements du secteur des services, mobilité du travail

\section{Copyright OECD 2005}

Applications for permission to reproduce or translate all, or part of, this material should be made to: Head of Publications Service, OECD, 2 rue André-Pascal, 75775 Paris Cedex 16, France. 


\section{TABLE OF CONTENTS}

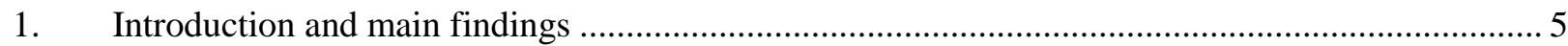

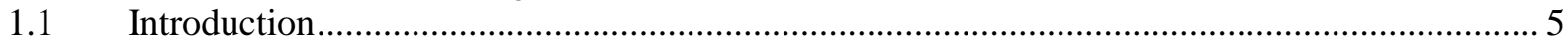

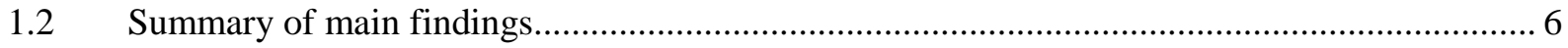

2. Sectoral re-allocation, economic performance and cross-country adjustment capacities ............... 7

2.1 Sectoral re-allocation and the shift to services..................................................................... 7

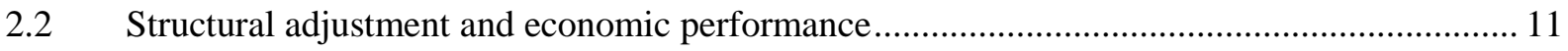

2.3 Cross-country indicators on adjustment capacities ............................................................. 14

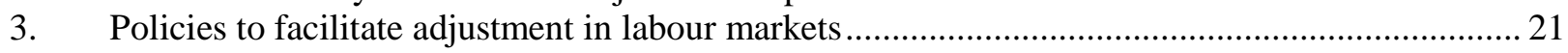

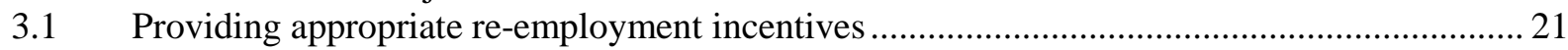

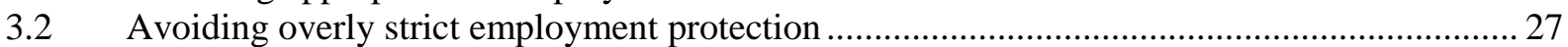

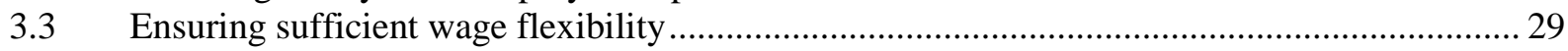

3.4 Raising skill levels to create a more flexible workforce ........................................................... 33

3.5 Reducing obstacles to mobility in the housing market ......................................................... 38

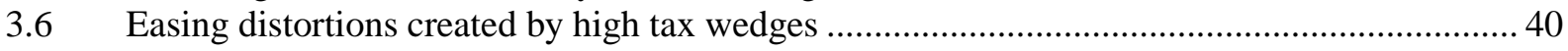

4. Removing barriers to competition and growth in service markets ............................................... 46

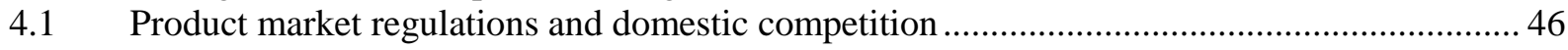

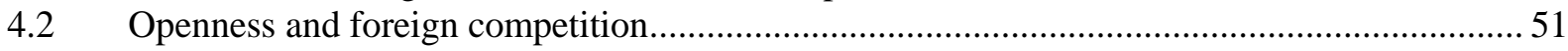

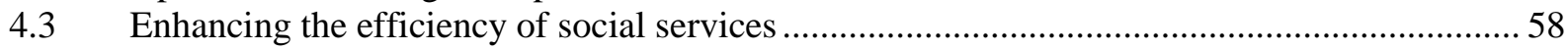

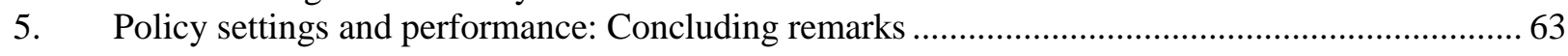

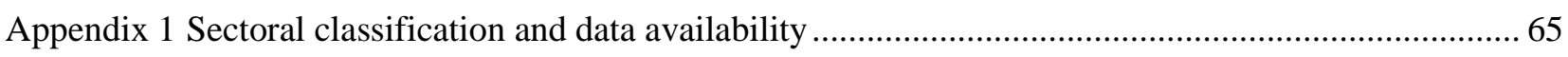

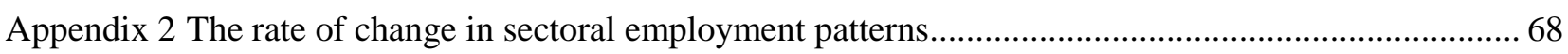

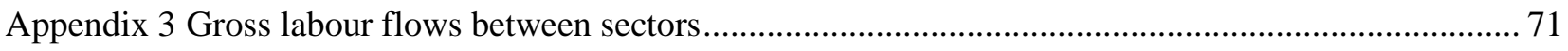

Appendix 4 Summary of country recommendations ................................................................................ 76

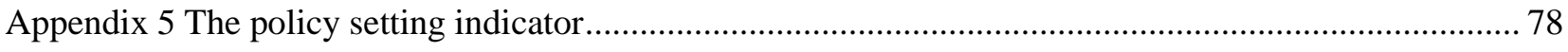

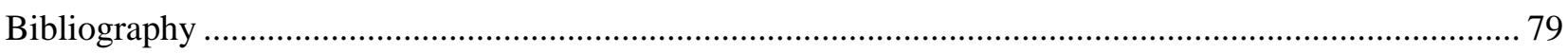

\section{Boxes}

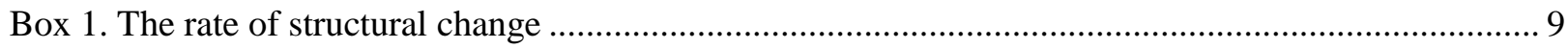

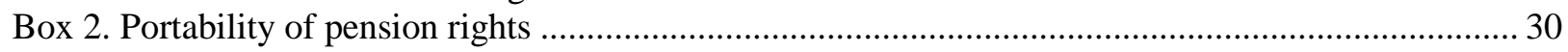

Box 3. Labour taxes and the number of hours required paying for personal services ............................. 40

Box 4. Female labour supply and service sector employment ............................................................... 45

Box 5. The wholesale and retail trade sector and overall economic performance ................................... 49

Box 6. Globalisation of services and job losses in the service sector ................................................... 53 


\section{Tables and Figures}

\section{Tables}

2.1. Gross labour flows between broad sectors

2.2. Correlations between countries ranking on performance indicators

3.1 Net replacement rates for workers moving from declining to expanding industries

3.2 Job displacement and wage losses

3.3 Tenure of housing

\section{Figures}

2.1 Employment and value-added in services

2.2 The size of the service sector and GDP per capita

2.3 Structural change and economic performance

2.4 Job characteristics by sector

2.5 Indicators of labour mobility

2.6 Indicators of service sector developments

2.7 Summary of country scores

3.1 Net replacement rates in unemployment benefit schemes (relative to previous earnings)

3.2 Net replacement rate in unemployment benefit schemes (relative to potential earnings)

3.3 Sanctions for behaviour during benefit period

3.4 Employment protection and employment in producer services

3.5 Employment protection legislation

3.6 Indicators of wage setting and industrial relations

3.7 Ratio of the minimum wage to full-time median earnings

3.8 Targeted employment subsidies for disadvantaged groups

3.9 Job loss rates and re-employment probabilities: United States

3.10 The impact of training on voluntary job mobility, involuntary separation and probabilities of re-employment

3.11 Indicators of education and in-work training

3.12 Spending on active labour market policies and training

3.13 Labour taxes and employment in services

3.14 Direct tax wedge on labour

4.1 Product market regulations and employment in market services

4.2 Regulations in selected service sectors

4.3 Domestic sectors exposure to trade

4.4 Barriers to foreign trade and investment

4.5 FDI regulations in selected services industries

4.6 The extent of free choice of government financed services

4.7 Private providers: market shares in selected services

5.1 Policy settings and countries' capacities to adjust 
ECO/WKP(2005)14

\title{
THE IMPACT OF STRUCTURAL POLICIES ON TRADE-RELATED ADJUSTMENTS AND THE SHIFT TO SERVICES
}

\author{
BY PER MATHIS KONGSRUD AND ISABELLE WANNER ${ }^{1}$
}

\section{Introduction and main findings}

\subsection{Introduction}

1. Long-term economic performance is closely linked to the capacity of countries to change their economic structure. This paper examines the policy stances that facilitate labour mobility and remove impediments to service sector development. The two issues are closely related. Barriers to service-sector expansion are harmful in themselves, but also because they may hamper the absorption of resources released by trade liberalisation and technological advances. At the same time, policies that impede the mobility of labour may hold back development of the service sector by slowing-down the transfer of resources from declining to expanding activities.

2. After a short scene-setting section on the link between structural changes and economic performance, the paper focuses on general structural policies that influence labour and product markets. Targeted policies, e.g. to limit the cost of adjustment for selected worker groups, firms or communities may be required when the general policy framework is insufficiently developed to cope with structural change, but in practice such special arrangements have often not succeeded in attaining their stated goals. ${ }^{2}$ Drawing predominantly on previous work carried out within the OECD, the policy areas examined for labour-market adjustment relate to benefit systems, employment protection legislation, wage-setting arrangements, education and training, housing policies and taxation, whereas the policy areas reviewed as impinging on product-market adjustment are domestic regulation, foreign trade and foreign direct investment, and the mode of provision of public services. For each area, the paper attempts to document the stance of policies in member countries, outline their impact on adjustment capacities, review recent reforms and report country-specific policy recommendations that have already been given in other recent OECD work, including individual OECD Country Surveys and the structural stocktaking exercise.

1. OECD Economics Department, 2 rue André-Pascal, 75775 Paris Cedex 16, France. Corresponding authors are Per Mathis Kongsrud (Email: permathis.kongsrud@oecd.org) and Isabelle Wanner (Email: isabelle.wanner@oecd.org). The authors would like to thank their OCDE colleagues, in particular JeanPhilippe Cotis, Jorgen Elmeskov, Mike Feiner, Sven Blöndal, Ken Heydon, Paul Swaim and Dirk Pilat, for their comments and inputs during the preparation of this study. They are also grateful to Sarah Kennedy and Caroline Abettan for valuable secretarial assistance. The views expressed here are those of the authors and not necessarily represent those of the OECD or its member countries.

2. For example, see the case studies discussed in OECD (2005a). 


\section{ECO/WKP(2005)14}

\subsection{Summary of main findings}

Setting the stage

3. All OECD countries have experienced a strong shift to services over the past decade. Manufacturing employment has declined in most countries, in absolute as well as relative terms, but this has been more than compensated by a strong growth in service employment. Sustained high levels of unemployment and weak employment creation in several OECD countries illustrate, however, that adjustment has been insufficient. At the same time, the development of service activities varies considerably across countries, largely reflecting differences in overall employment rates.

\section{Policies to facilitate adjustments in labour markets}

4. Countries' adjustment capacities depend to an important extent on policies affecting the labour market. These policies have typically been put in place in order to attain specific policy aims (notably social objectives) but may inadvertently contribute to slowing down adjustment in labour markets. A summary of conclusions emerging from Section 3 are as follows:

- Unemployment and related benefits have a role to play in easing adjustment costs for affected individuals, and may to some extent reduce public resistance to structural change. However, benefits that are made available to displaced workers at a high rate and for a long duration may also slow down adjustments to structural change by reducing the pressure on affected individuals to find gainful employment - particularly when counteracting measures in the form of e.g. activation policies, job-search requirements and work-availability conditions are too weak.

- Overly strict employment protection may have adverse effects on firms' capacity to reorganise and implement new technologies. This may potentially hamper developments in sectors characterised by rapid technological change and large variations in demand, such as many producer services. Strict employment protection could also reduce the flow of new vacancies, thus hampering the re-integration of displaced workers, impeding job-to-job mobility and lowering the efficiency of active labour market policies.

- Rigidities in aggregate and relative wages can hold back structural adjustments, resulting in prolonged slack in the labour market and providing few incentives for workers to change industry, to move to another region and to invest in human capital. Relatively high statutory or bargained minimum wages may hamper wage flexibility for the low-skilled, and may depress low productivity service activities that provide the only viable job opportunities for some people.

- A well-educated work force is better placed to adopt new technology and production methods, and is more mobile across occupations, regions and industries. Service sector jobs are also increasingly highly-skilled, raising the risk that labour shortages could hamper developments in certain service segments. For displaced and unemployed workers, effective re-training systems could be of particular importance as new skills might be a precondition for successful reintegration.

- Regional labour mobility could be seriously hampered by rigidities in the rented housing sector and high taxes on property transactions. Rigid housing supply, because of planning and zoning restrictions, may further prevent net inflows of workers to expanding areas. Such inefficiencies can be especially detrimental when displacements are concentrated in certain geographical areas. 
- Development in some expanding service sectors could also be obstructed by high labour and consumption taxes. The personal service sector is likely to be most affected, as it relies disproportionately on workers with elastic labour supply (e.g. low-skilled and second-income earners) and delivers services where do-it-yourself or informal production is a viable alternative.

\section{Policies to facilitate competition and growth in product markets}

5. Policies to strengthen competition in domestic markets have an important role to play in promoting an efficient and dynamic economy, and thus facilitating structural adjustments. The main findings in this area are reviewed in Section 4:

- Competition can act as a spur to innovation and strengthens firms' incentives to adopt best practices and to respond to clients' needs. It could further stimulate activity and increase labour demand by reducing rents and, thus, the potential for rent sharing. Moreover, lower rents could help reduce resistance to change and allow benefit systems to function more efficiently.

- Trade and foreign direct investment (FDI) can help create a more efficient service sector by providing more competition, bringing new services to the market and creating new market possibilities through exports. Electronic commerce and global delivery of business services may provide significant opportunities in this respect.

- Important services like education and health care are usually delivered in a non-market environment and provided free of charge, or at heavily subsidised prices, at the point of delivery. This setting could diminish the development of services that nonetheless have high private return and positive externalities, by making producers less responsive to user needs. While opening-up to private providers and relying more on market instruments is not the answer across the board (e.g. in cases where they conflict with fundamental equity objectives or where significant market failures exist), a greater role for market mechanisms could improve efficiency in social services.

\section{Sectoral re-allocation, economic performance and cross-country adjustment capacities}

\subsection{Sectoral re-allocation and the shift to services}

6. The sectoral composition of OECD economies has changed significantly over time, with services playing an increasingly important role. The service sector now accounts for roughly $70 \%$ of all jobs and value-added in the OECD area, which is up by more than 5 percentage points since 1990 (Figure 2.1). The expansion of services has changed the on-going process of sectoral re-allocation, with adjustments within services becoming a quantitatively more important component of overall re-allocation (Box 1).

7. This shift of employment to services has been driven by strong economic forces that have acted on all countries:

- High income elasticity. Some services are characterised by relatively high income elasticities of demand, implying a tendency for the share of services in total real expenditure to rise as income grows (Schettkat and Yocarini, 2003). High income elasticity may also help explain the strong increase in collective consumption, i.e. the expansion of the welfare state.

- Low productivity growth in conjunction with low price elasticity. Many service activities (but not all) have, at least historically, had less potential for productivity improvements than goodsproducing sectors. Since wages in services have tended to develop in line with those of other sectors of the economy, the relative price of services has increased, but without dampening demand markedly because the price elasticity is often relatively low. As a result, and in the 
Figure 2.1. Employment and value-added in services

Per cent

A. Employment in services as a share of total employment ${ }^{1}$

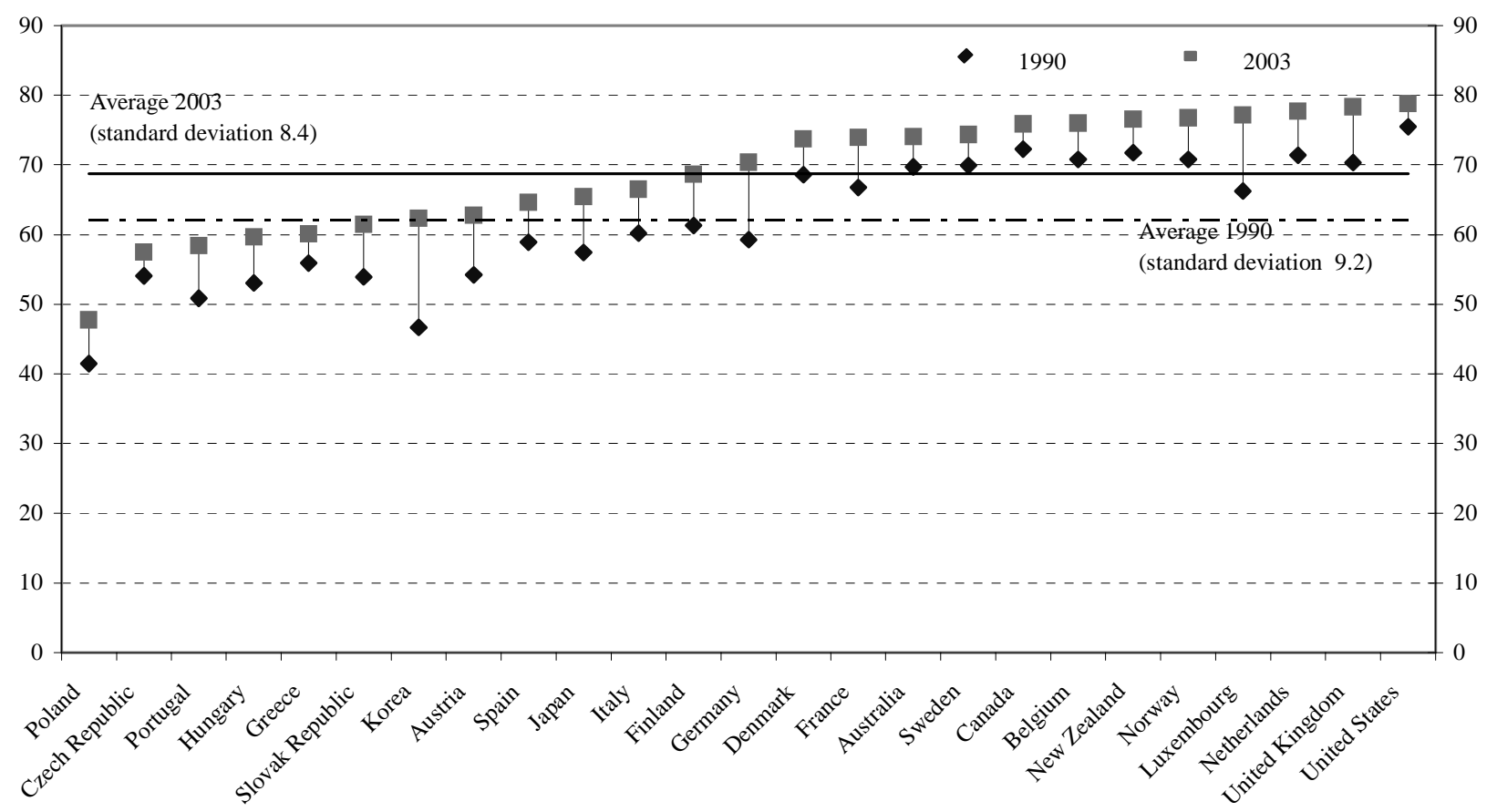

B. Value added in services as a share of total value $\operatorname{added}^{1}$

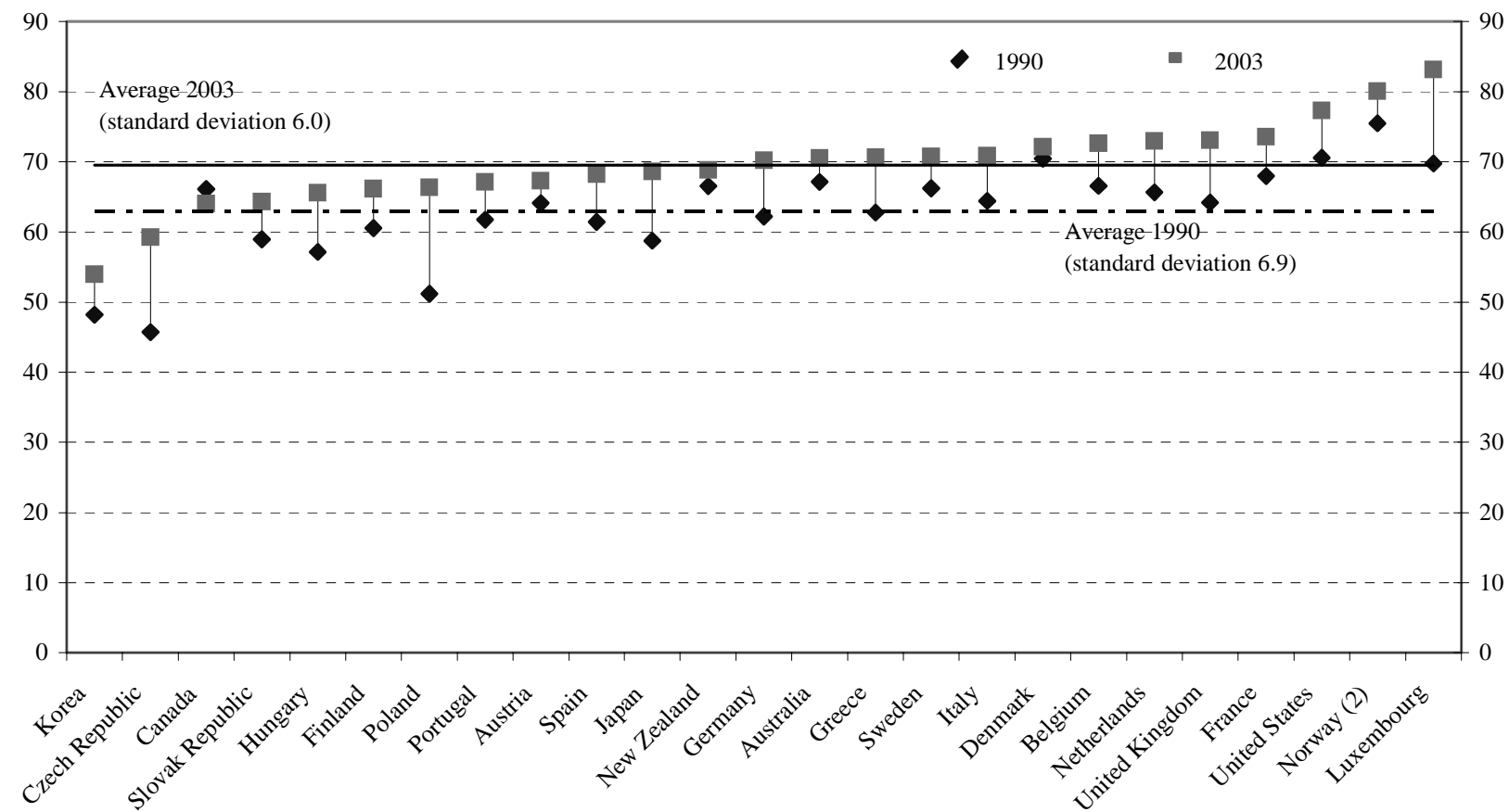

1. See Appendix 1 for industry classification and data availability.

2. Mainland Norway.

Source: The OECD STAN Database for Industrial Analysis. 


\section{Box 1. The rate of structural change}

Developments in sectoral employment shares provide one, albeit simple, measure of structural change. ${ }^{1}$ The evolution of the adjustment process over time is sketched in the figure below, pointing to the conclusions that:

- At an aggregate level - where the economy is divided into only three sectors - a clear trend decline in the rate of structural change can be identified over the past three decades. This should not be surprising, as it largely mirrors the diminishing role of goods-producing sectors - and thereby of shifts out of these - in overall employment.

- More disaggregated indicators show less of a decline over time. This suggests that structural changes in employment patterns take place to an increasing extent between broad industries within the service sector, as shifts of employment from goods-producing sectors to services have tapered off. This pattern is likely to persist, not least because new service industries and categories of employees are becoming exposed to international competition.

- The structural-change indicators, and in particular the aggregated ones, may suggest a cyclical pattern, with peaks in net sectoral labour flows during recessions (as in the early 1990s). This suggests that the structure of the economy is not evolving smoothly, underlining that involuntary job displacements are an integral part of the process.

\section{The rate of change in sectoral employment patterns}

OECD average, three-year moving averages, index $1981=1^{1,2}$

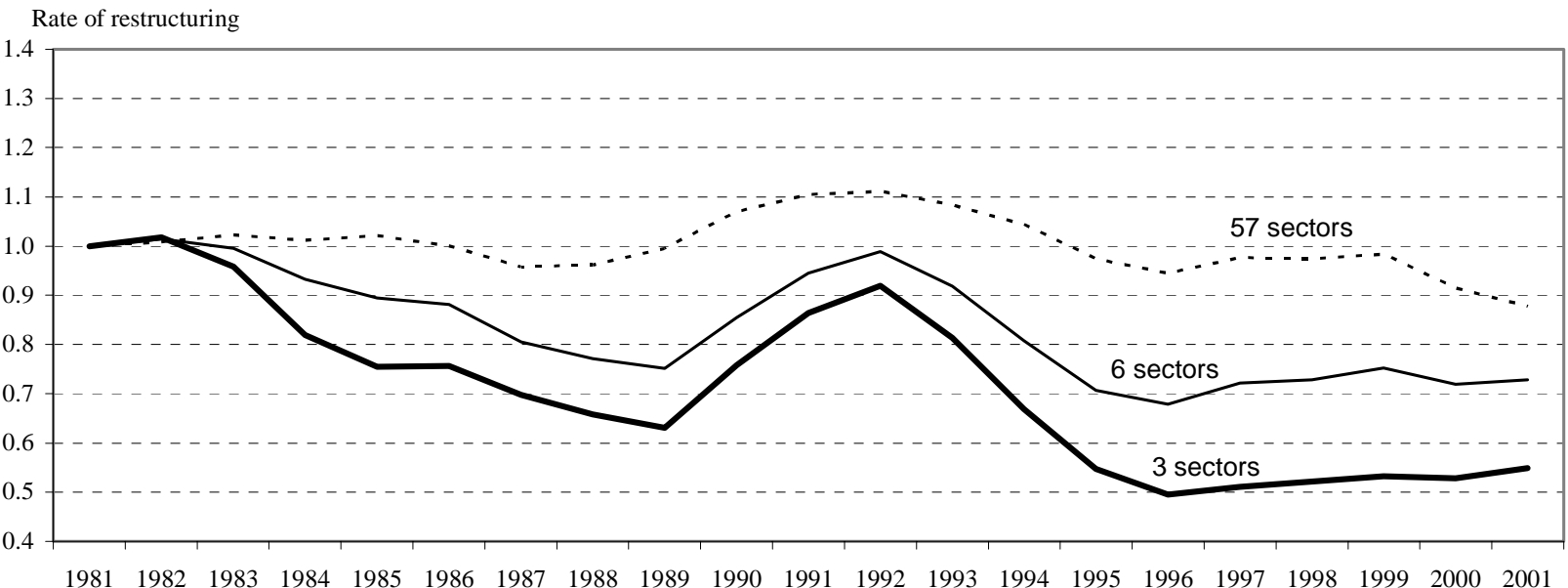

1. The rate of restructuring is calculated as: $\quad 0.5 \cdot \sum_{i}\left|N_{i, t}-N_{i, t-1}\right|$, where $\mathrm{N}_{\mathrm{i}, \mathrm{t}}$ denotes the share of sector $\mathrm{i}$ in total employment at time t. An unchanged employment pattern returns an indicator value of zero. The indicator is calculated for three sectors (primary, secondary and tertiary industries), six sectors (dividing services into producer, distributive, social and personal services) and 57 sectors. See Appendix 1 for sectoral classification.

2. Simple average of 20 OECD countries. See Appendix 2 for individual country results.

Source: The OECD STAN Database for Industrial Analysis and Groningen Growth and Development Centre Database.

1. The rate of structural change cannot easily be measured as it involves changes within firms, as well as between firms, industries and regions. The indicators presented in this box are also subject to certain limitations. They are, for instance, sensitive to the chosen aggregation level, and pick up relative expansion and contraction of sectors over the business cycle. See European Commission (2000) and Greenaway et al. (2000) for recent examples on the use of this type of indicators. 
context of high income elasticity, the share of services in nominal value-added has tended to increase (a phenomenon first elaborated on in Baumol, 1967 and Fuchs, 1968). ${ }^{3}$

- International trade. The structure of the economy may also change in response to trade and international competition, as countries make use of their comparative advantages and specialise in services, goods production or resource-based industries (Rowthorn and Wells, 1987). This is illustrated by the emergence of developing non-OECD countries specialising in goods production (e.g. China). In addition, trade fosters the shift towards service in an indirect way to the extent that it contributes to increased incomes.

- Outsourcing of service work. A pure re-labelling effect has also been at play, as goods-producing firms have increasingly relied on deliveries of intermediate inputs from specialised domestic service firms as an alternative to in-house production. However, outsourcing seems to account for a relatively minor share of the observed strong growth in producer services over the past few decades (Russo and Schettkat, 2001).

Figure 2.2. The size of the service sector and GDP per capita $2003^{1}$

A. Value added shares in services and GDP per capita

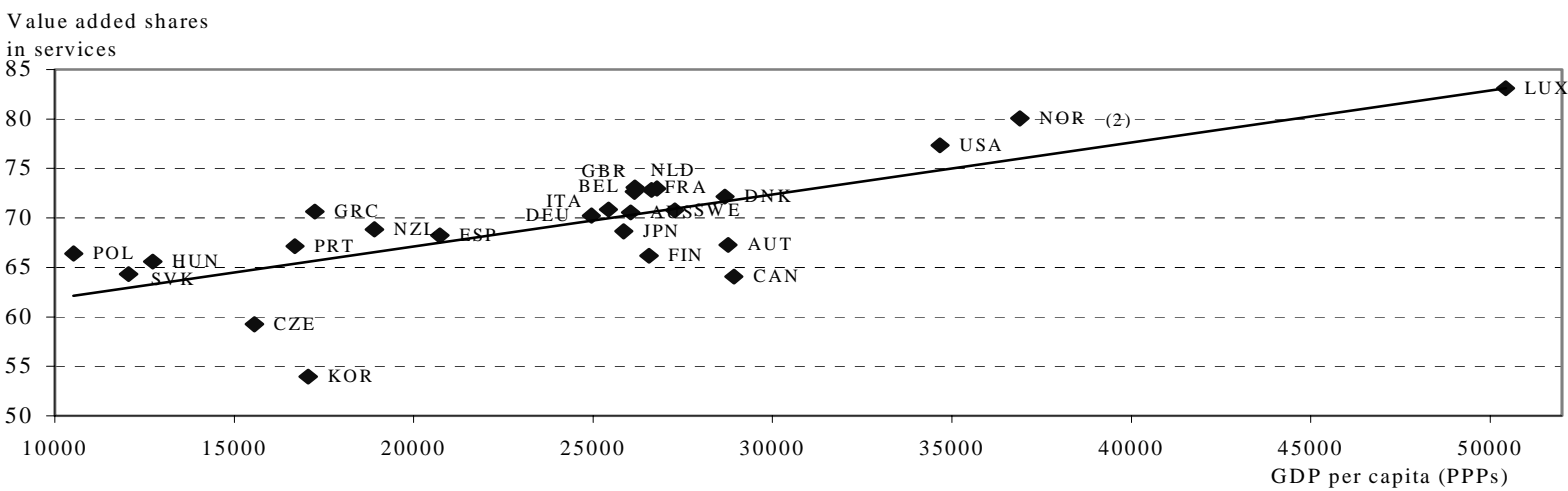

B. Employment shares in services and GDP per capita

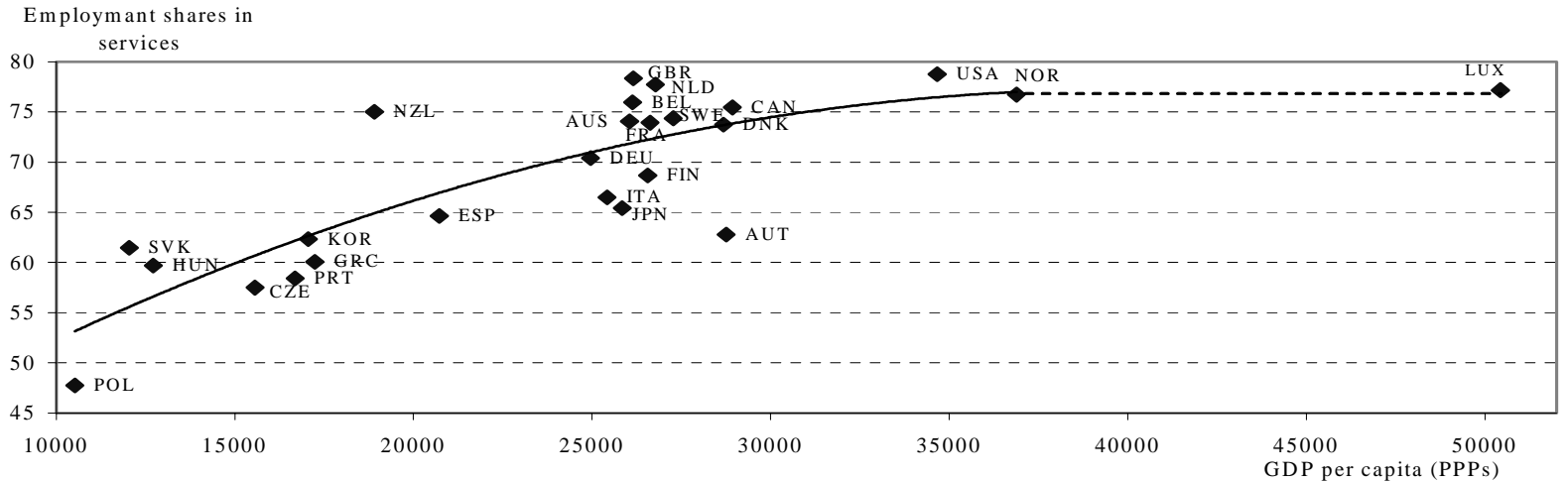

1. See Appendix 1 for industry classification and data availability.

2. The value added share for Norway refers to the mainland economy.

Source: The OECD STAN Database for Industrial Analysis and OECD Analytical Database.

3. The measurement of service sector productivity is subject to some serious problems (Wölfl, 2003). This makes it difficult to assess precisely the separate impact of productivity growth, price elasticity and income elasticity on service sector developments. 


\subsection{Structural adjustment and economic performance}

8. The shift to services has taken place mainly through a relatively smooth process in most countries. Labour resources have gradually shifted to services as new groups - cohorts of young people and women - have entered the labour market (see below). This has been accompanied by adjustments of the capital stock as fixed investments have shifted towards expanding firms and industries. However, firm closures involving involuntary job displacements and premature scrapping of capital have been inevitable. Although the available evidence is limited, it suggests that 3 to $5 \%$ of the OECD workforce has experienced an involuntary layoff in any given year (Kuhn, 2002). The associated adjustment can be painful for the individuals and communities involved, while costs for society as a whole can be large in terms of lost production, particularly if the adjustment mechanisms are weak (i.e. insufficient labour mobility and wage flexibility).

Figure 2.3. Structural change and economic performance

\section{A. Manufacturing employment and unemployment, 1990-2003 ${ }^{1}$}

Average annual employment contribution from manufacturing, per cent (2)

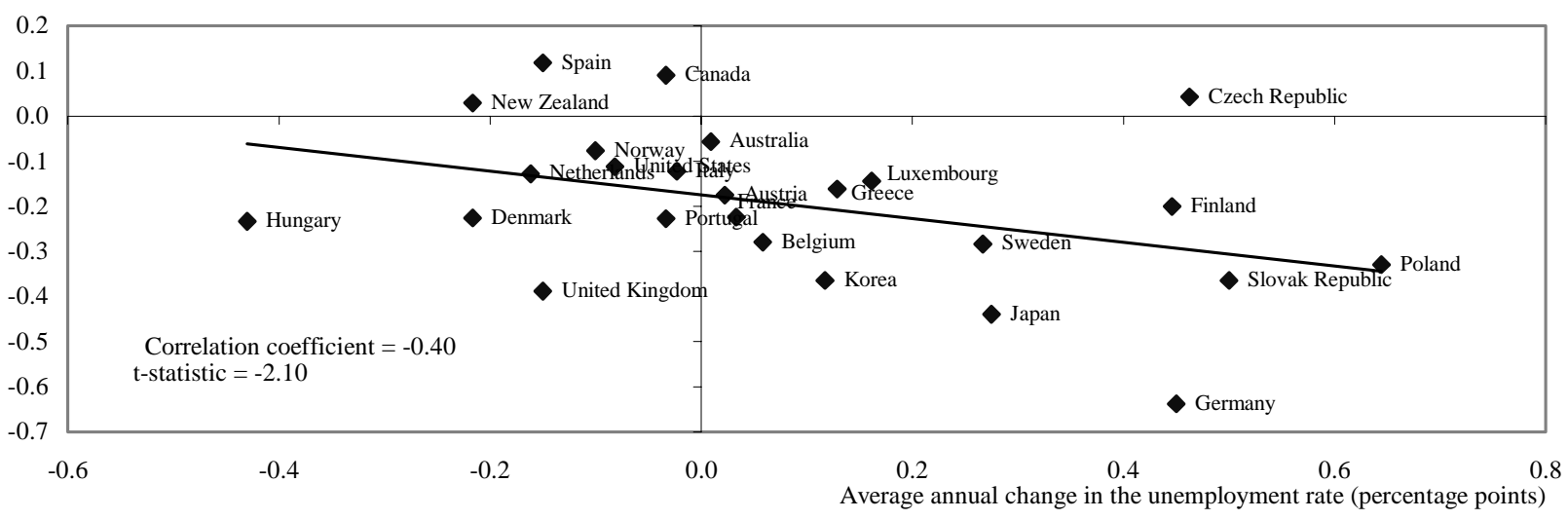

B. Service employment and total employment, per cent of working age population, $2003^{1}$

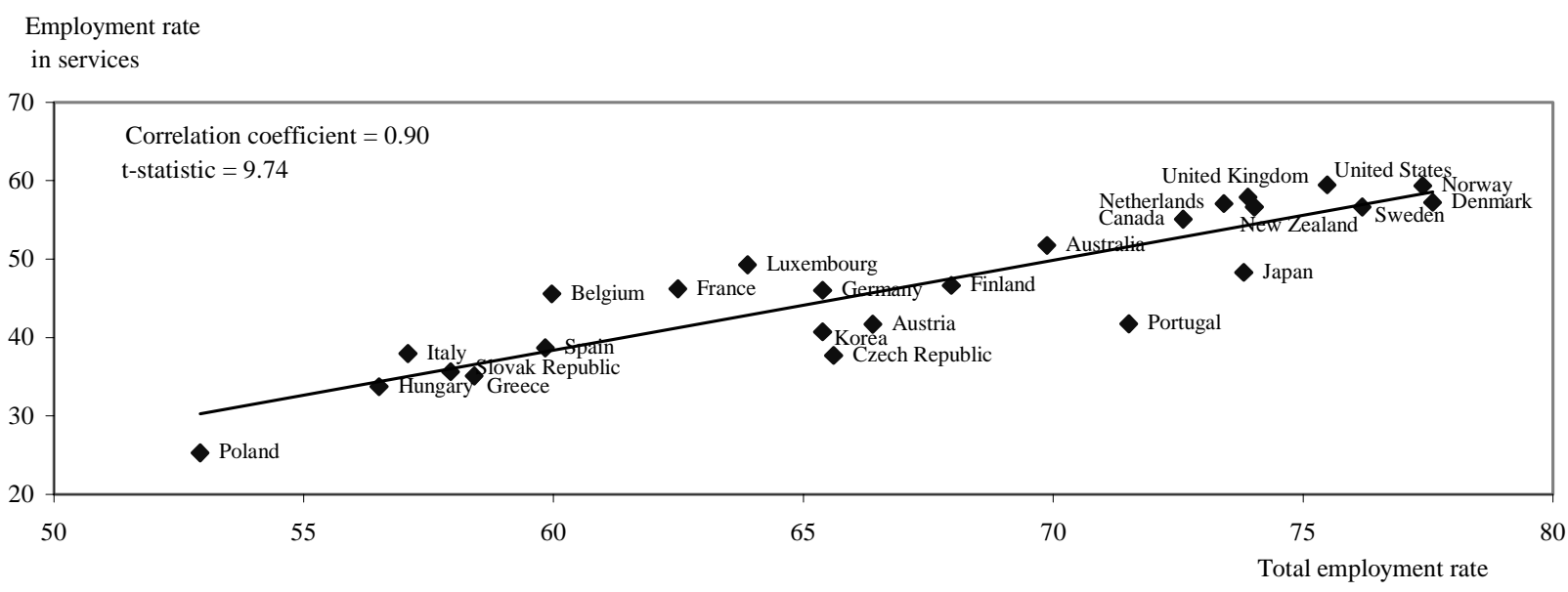

1. Or first and latest year available. See Appendix 1 for industry classification and data availability.

2. Change in manufacturing employment from 1990 to 2003 in per cent of total employment in 1990.

Source: The OECD STAN Database for Industrial Analysis and OECD Labour Force Statistics. 
9. Most OECD countries have had problems in adjusting to structural change. Declining employment in manufacturing has, for example, often been associated with increasing aggregate unemployment levels (Figure 2.3, Panel A). Thus, countries with a sharp drop in manufacturing employment, such as Germany and Japan, have tended to experience a relatively large rise in unemployment, while a few countries recording a rise in manufacturing employment have all seen a drop in unemployment. There are some exceptions to this general pattern, suggesting that the adjustment capacities have been sufficiently strong to cope with the decline in manufacturing employment in some countries. For example, the United Kingdom, and, to a lesser extent, Denmark and Hungary, achieved a significant reduction in their unemployment rates despite recording strong declines in manufacturing employment since the early 1990 s. $^{4}$

10. On the other hand, there seems to be a clear positive relationship between the size of the service sector and overall employment rates (Figure 2.3, Panel B). It underlines that for most OECD countries, the expansion of services is largely about mobilising new worker groups and raising overall employment, and not only moving labour resources from goods-producing activities. The observed country differences may, therefore, signal that countries differ in their ability to take advantage of the service sector as a vehicle for job creation and high labour force participation. Indeed, service sectors may provide the kind of jobs needed to attract new worker groups (including part-time, evening, night and low-skilled work). Alternatively, the cross-country variations could indicate that higher labour force participation provides an impetus to service sector development, for instance through its effects on incomes.

11. On average, for the 12 European countries for which comparable data are available, direct job-tojob flows between broad sectors of the economy have played a minor role in the reallocation process (Table 2.1). Direct gross labour flows between primary and secondary industries on the one hand, and tertiary industries on the other, have been of approximately the same magnitude, thus resulting in very small net labour flows. This has been the case in all countries, despite significant differences in gross labour flows, as documented below. Net transfers of labour resources from declining to expanding activities have thus been accounted for mainly by new entrants in the labour market and, possibly, workers experiencing temporary unemployment spells. However, with relatively weak underlying growth in the labour force in most OECD countries in the coming years, sectoral adjustments must increasingly involve changes of careers for existing workers.

Table 2.1. Gross labour flows between broad sectors

Per cent of total employment, average $2000-03^{1,2}$

\begin{tabular}{lcc}
\hline From sector/labour market status & Gross & Net $^{3}$ \\
\hline & To tertiary industries \\
\cline { 2 - 3 } Primary industries & 0.2 & 0.0 \\
Secondary industries & 0.7 & 0.0 \\
Unemployed & 2.9 & 1.2 \\
Inactive & 6.6 & 4.6 \\
& \multicolumn{2}{c}{ To secondary industries } \\
Primary industries & 0.1 & 0.0 \\
\hline 1. Defined as workers employed at the survey date and reported to have worked \\
in a different sector one year earlier. & & \\
2. Unweighted average of 12 European countries. See Appendix 3 for details. \\
3. Gross inflow minus gross outflow. \\
Source: European Labour Force Survey.
\end{tabular}

4. See OECD (1997) for a discussion of employment adjustment and unemployment. 
12. A key challenge with reallocation of labour resources is that the characteristics of jobs and workers differ markedly across sectors (Figure 2.4). This makes it harder for low-skilled workers displaced from the declining manufacturing sector to find new jobs. Re-employment in social and producer services can be particularly hard, as they typically rely on workers with a much higher level of formal education. By contrast, personal and distributive services provide a large number of jobs for low-skilled workers, and both these sectors are also expanding in terms of employment in most OECD countries. This makes it easier for displaced manufacturing workers to enter these sectors. However, other job characteristics differ substantially from manufacturing, including the incidence of part-time jobs. Moreover, some personal and distributive services (including hotels and restaurants and retail trade) offer lower pay than manufacturing, even for workers with comparable skills and other characteristics.

Figure 2.4. Job characteristics by sector OECD average
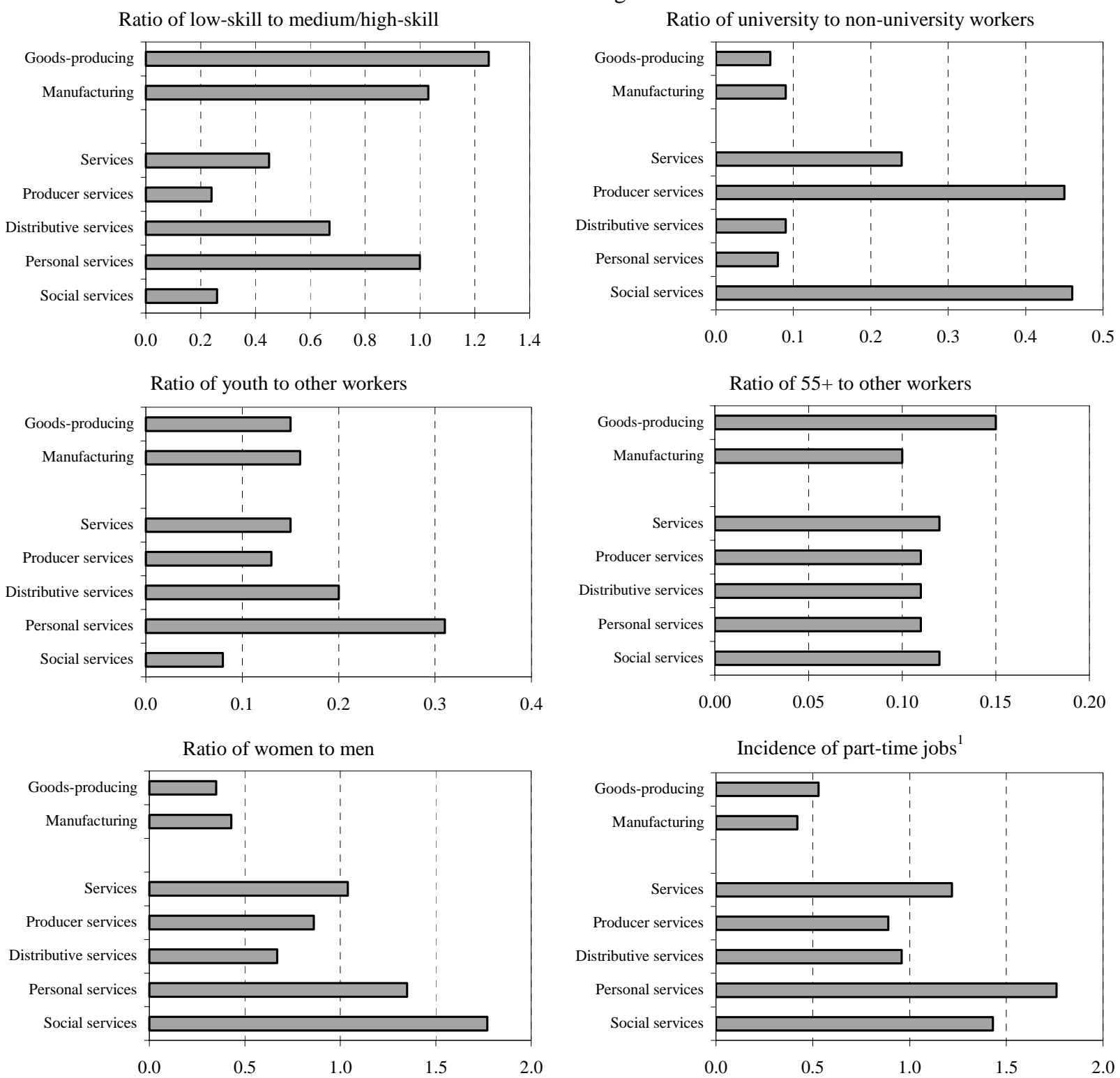

1. Ratio of incidence of part-time employment in each sector to average incidence for all sectors.

Source: OECD Employment Outlook 2000, Chapter 3; OECD Employment Outlook 2001, Chapter 3; and Jean and Nicoletti (2002). 
Figure 2.4. Job characteristics by sector (cont.)

OECD average
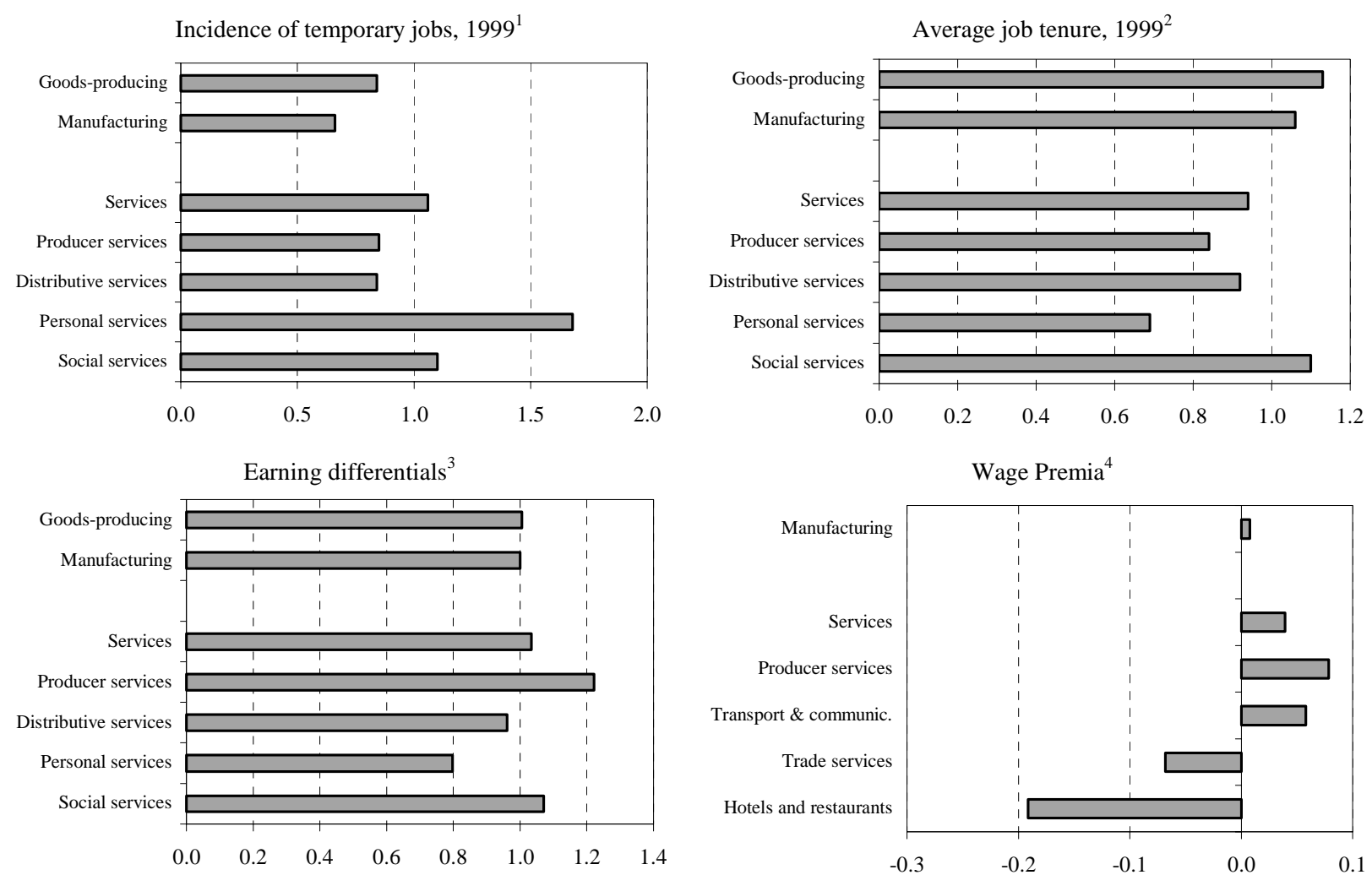

1. Ratio of incidence of temporary employment in each sector to average incidence for all sectors.

2. Ratio of average tenure for each sector to average tenure for all sectors.

3. Ratio of average earnings in each sector to average earnings in manufacturing.

4. In logarithm, compared to the economy-wide, employment weighted, average wage. Simple average of industry estimates.

Source: OECD Employment Outlook 2000, Chapter 3; OECD Employment Outlook 2001, Chapter 3; and Jean and Nicoletti (2002).

\subsection{Cross-country indicators on adjustment capacities}

13. The capacity of countries to manage structural adjustments, including trade-related ones, is reflected in broad indicators of performance, such as GDP, productivity, employment and unemployment. More detailed indicators are, however, needed to highlight countries' performance along particular dimensions of adjustment. Labour mobility involves, for example, mobility between firms, industries and regions, as well as from unemployment and inactivity to employment. ${ }^{5}$ Similarly, the extent to which countries have fostered the service sector, with its means to provide more jobs and raise overall employment, can be measured in different ways. The next two sub-sections present alternative indicators for labour mobility and developments in services, respectively. Admittedly, the indicators presented are simple and should be interpreted with caution.

5. In addition, important adjustments take place within firms through internal job mobility and skill upgrading, although little cross-country evidence is available. 


\section{Adjustment capacities for sectoral reallocation}

14. Measuring countries' capacities to adjust in labour markets is fraught with difficulties. In particular, country disparities in re-allocative turnover could reflect differences in the magnitude of structural shocks, i.e. differences in countries' adjustment needs, rather than differences in adaptive capacity. Some labour turnover may also be unproductive. Despite these shortcomings, available indicators may help shed some light on countries' capacities to re-allocate labour resources, capturing different aspects of the adjustment process:

- Indicators of unemployment persistence can be used as measures of countries' capacity to re-employ displaced labour resources. Both long-term unemployment and outflow rates from unemployment show large country differences (Figure 2.5, Panels A and B). ${ }^{6}$ The incidence of long-term unemployment is particularly high in Greece, Italy and the Slovak Republic, while outflow rates from unemployment are relatively low in France, Germany, Greece, Italy and Spain.

- $\quad$ Average job tenure provides a relatively broad indicator of overall turnover in the labour market. ${ }^{7}$ The average job tenure is relatively high in several continental European countries and Japan, compared with Australia, Iceland, the United Kingdom and the United States (Figure 2.5, Panel C). However, tenure can be high for both "good" and "bad" reasons, making interpretation difficult.

- Job-to-job mobility between industries is of particular importance when the structure of the economy is changing. In the 14 European Union countries where data are available, labour movements between similarly defined industries seem to be particularly low in Belgium, Greece, Germany and Portugal (Figure 2.5, Panel D). The extent to which this reflects cross-country differences in mobility is not clear, however.

- Regional labour mobility is important to handle structural change that has uneven geographical impact. The incidence of internal migration seems to be especially low in several continental European countries, including the Czech Republic, Italy, Portugal and Spain (Figure 2.5, Panel E) ${ }^{8}$ This may indicate insufficient regional labour mobility given that the dispersion in regional unemployment rates is relatively high in several of these countries (Figure 2.5, Panel F). ${ }^{9}$

6. It should be noted, however, that both these indicators could be distorted by, for instance, countries' use of ALMPs and EPL allowances for temporary contracts.

7. This indicator could also be distorted by, for instance, countries' use of ALMPs and EPL allowances for temporary contracts.

8. The cross-country comparability of indicators on regional mobility could be questioned as they may depend on how the regions are defined in each country.

9. The relative unemployment level of individual regions is also fairly persistent over time. OECD (2000a) reports, for example, rank correlation coefficients for regional unemployment rates of above 0.80 for most countries between the early and late 1990s. The main exceptions are Australia and the United States, with a somewhat lower correlation. 
Figure 2.5. Indicators of labour mobility

A. Incidence of long-term unemployment, $2003^{1}$

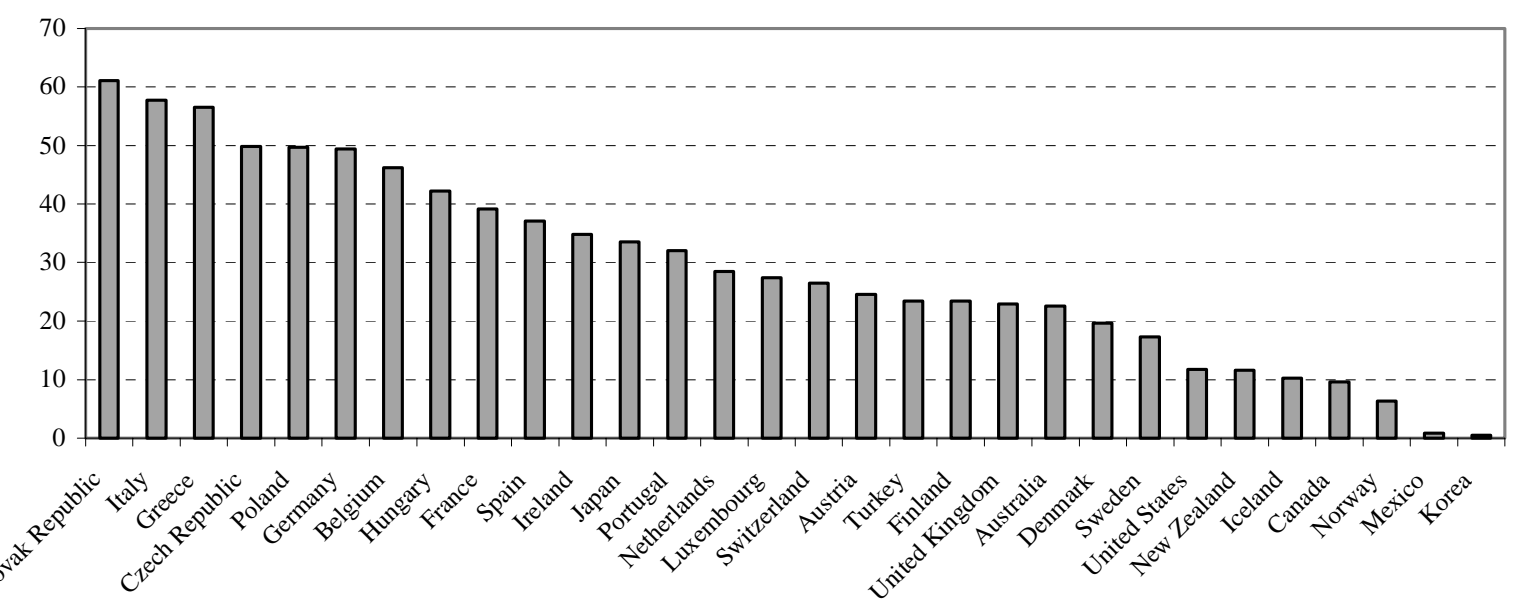

B. Outflows out of unemployment in an average month (\% of total unemployment), 2002

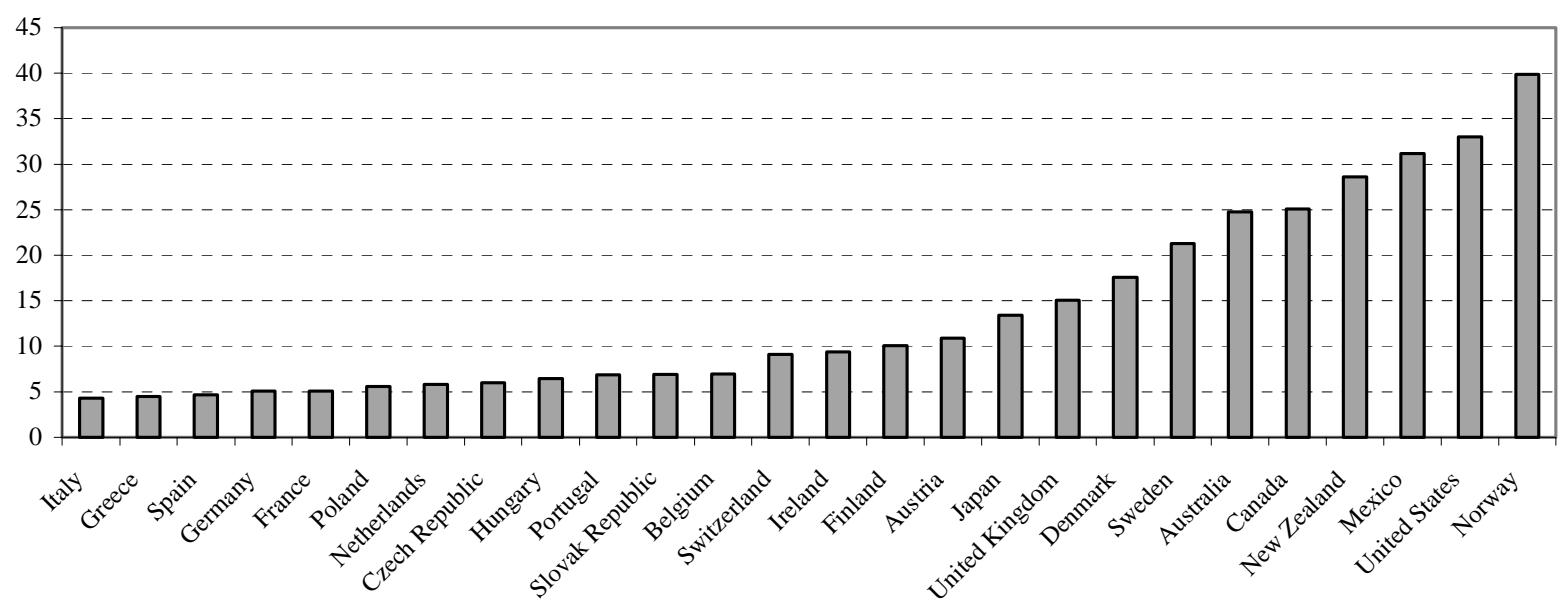

C. Average job tenure (years), $2003^{2}$

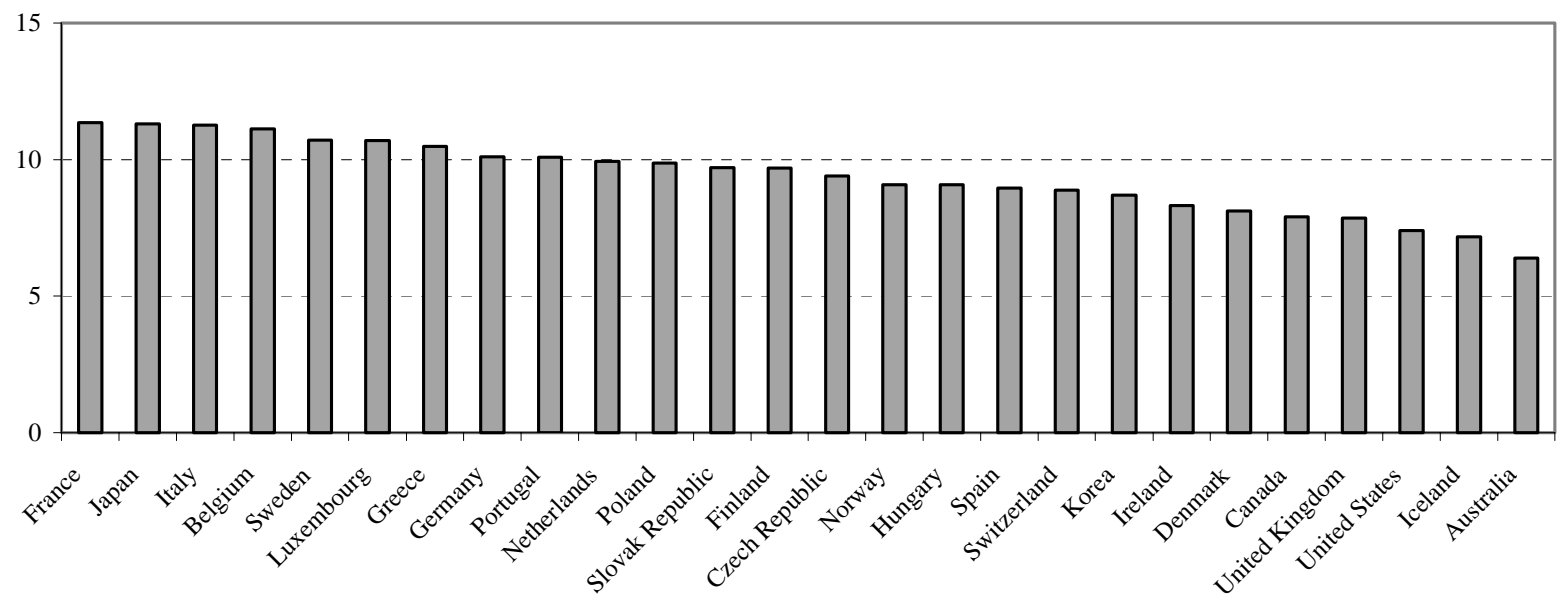

1. Defined as those unemployed continously for 12 months or more as percentage of total employment. 2. Or latest year available.

Source: OECD Labour Force Statistics and OECD Employment Outlook 2004. 
Figure 2.5. Indicators of labour mobility (cont.)

D. Gross labour flows between industries ( $\%$ of total employment), $2003^{1}$

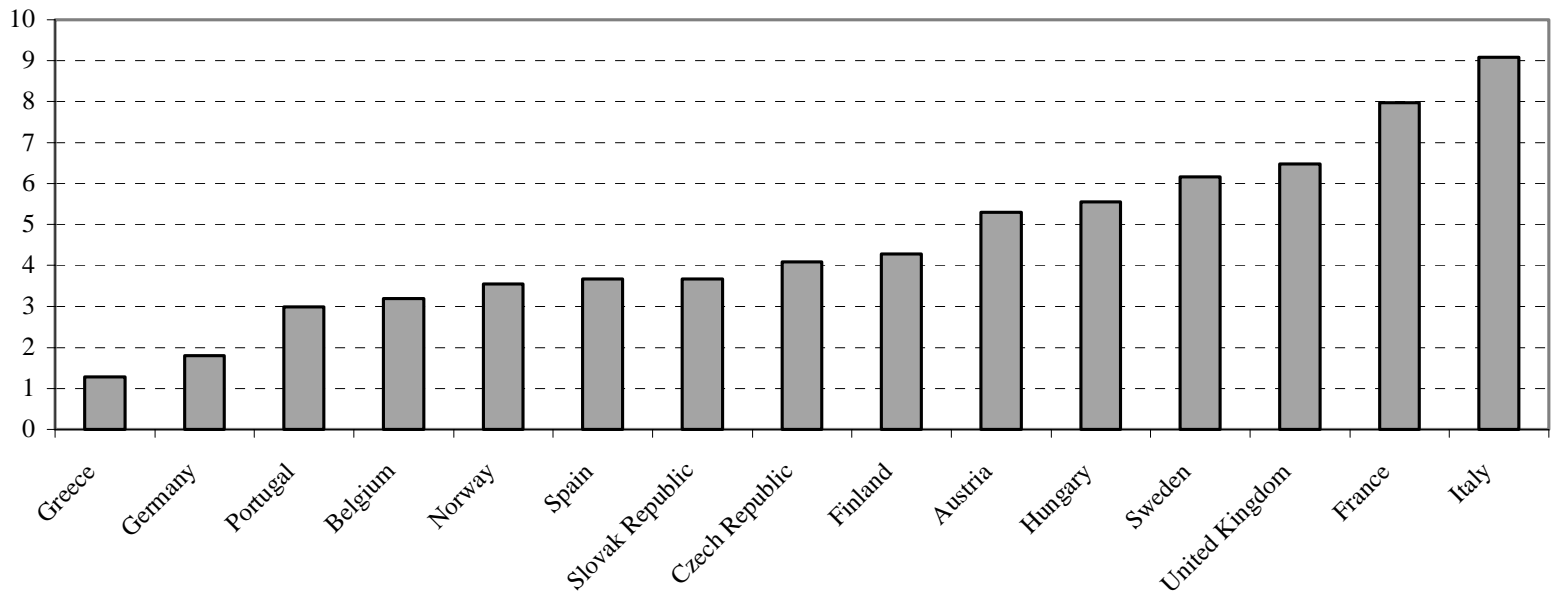

\section{E. Internal migration (ratio of gross flows to population), mid-1990s}

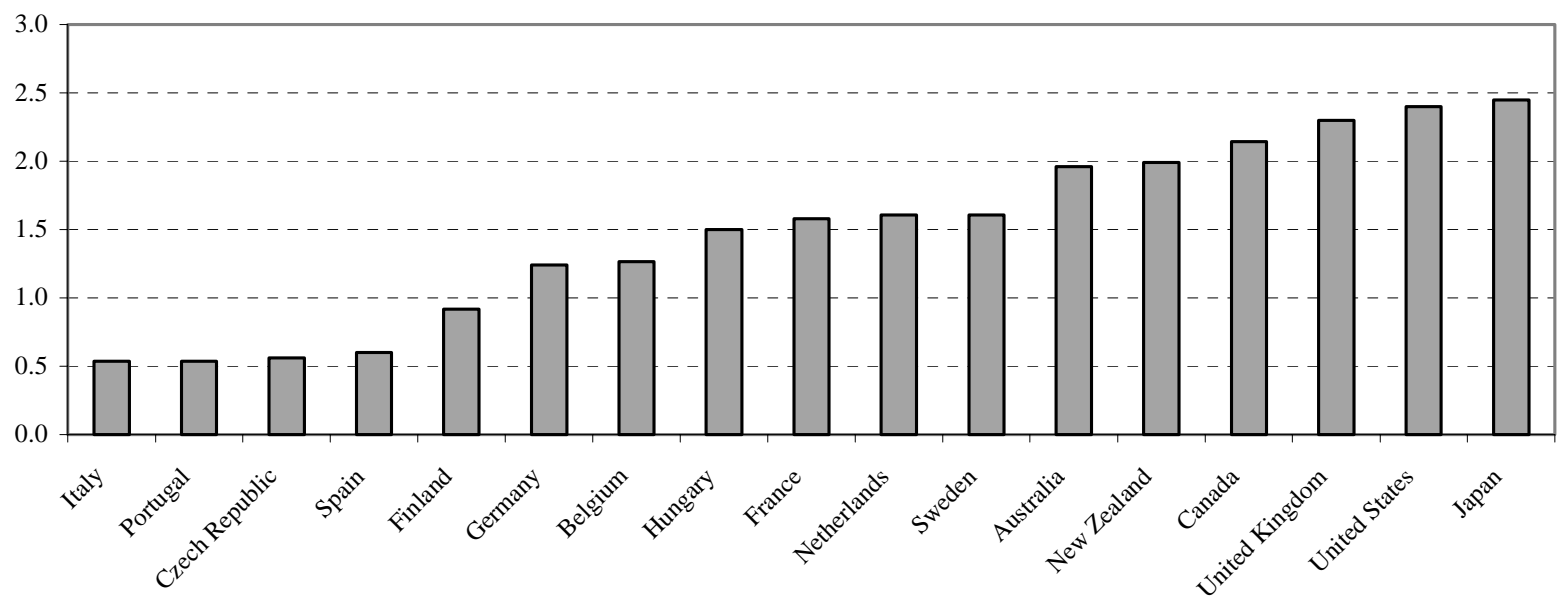

\section{F. Regional unemployment dispersion, 2002}

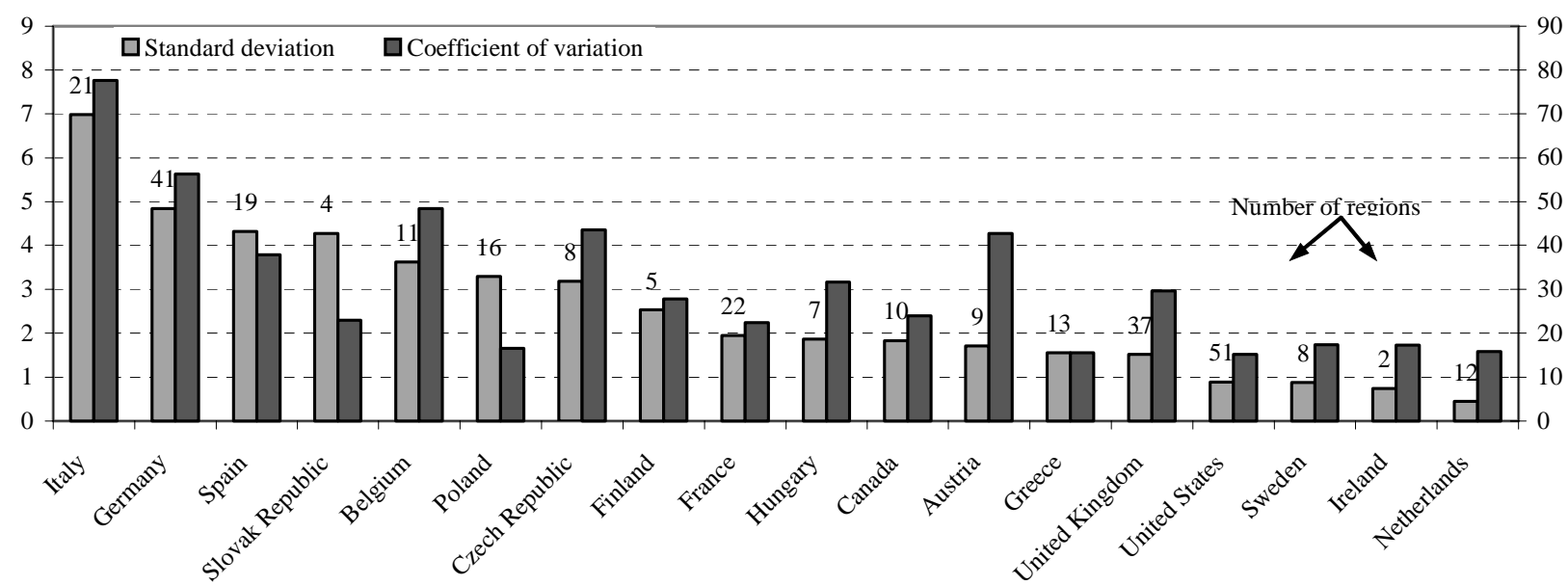

1. At the 2-digit NACE level. Defined as workers employed at the survey date and reported to have worked in a different sector one year earlier. The data for France refer to 2002.

Source: European Labour Force Survey, OECD Employment Outlook 2000, Eurostat. 


\section{ECO/WKP(2005)14}

\section{Indicators for service sector development}

15. Measuring the extent to which countries are able to foster growth of the service sector is even more difficult than measuring adjustment capacities in labour markets. In particular, cross-country comparisons need to take account of differences in GDP per capita, as the role of services tends to increase with income. But, even a comparison between countries at roughly similar income levels is difficult because no uniform optimal service sector size exists. Some countries may, for instance, specialise in financial service or tourism, resulting in relatively high service shares, while others may have comparative advantages in goods-production or extraction of natural resources. However, as noted above, expanding the service sector is largely about mobilising more labour resources, at least for countries with relatively low overall employment levels.

16. Two of the three indicators suggested below (the value-added share and the employment share) adjust for different income-per-capita levels, although in an admittedly simple way by comparing outcomes with values predicted on the basis of country income (as indicated in Figure 2.2). No attempt is made to estimate the gap between the actual and optimal relative size of the service sector for each country. The last indicator (the employment rate in services) is included as a measure of the ability of countries to take the opportunities offered by the service sector to create more jobs and raise overall labour utilisation (see Figure 2.3, Panel B). The indicators used to measure the capacity of countries to develop the service sector, and the broad picture they give, are as follows: ${ }^{10}$

- The deviation between the actual value-added share in services and the predicted share based on income suggest that the size of the service sector is relatively small in Austria, Canada, the Czech Republic and Korea (Figure 2.6, Panel A).

- Similarly, the difference between the actual employment share in services and the predicted share based on income suggests that service employment is relatively low in Austria, Italy, Japan and Poland (Figure 2.6, Panel B).

- Finally, the employment rate in services (i.e. employment in services relative to the working age population) differs widely between countries, and is relatively low in Greece, Hungary, Poland and the Slovak Republic (Figure 2.6, Panel C).

\section{Summing-up: Adjustment capacities and service sector developments}

17. The sub-indicators presented above can be summarised in two broad indicators: $i$ ) the capacity of labour markets to adjust and $i$ ) the capacity of countries to foster service-sector expansion and thereby to create more jobs and raise overall employment. Both summary indicators are calculated as the simple average of countries' rankings on the respective sub-indicators. The labour market indicator is, however, based on only three of the six sub-indicators (including incidence of long-term unemployment, outflow from unemployment and average job tenure). This is to ensure wide country coverage as some of the indicators were only available for a sub-group of countries. The loss of information because of this may be mitigated to some extent as two of the omitted series (internal migration and regional unemployment dispersion) are strongly correlated with the first two of the series included (Table 2.2).

10. These indicators are all aimed at measuring the size of the service sector, including public services. Alternative indicators of service sector developments, e.g. growth in employment and productivity, have also been considered. It is, however, difficult to adjust such indicators for catching-up effects and other differences in starting conditions, and they have not been incorporated into the performance indicator. 
Figure 2.6. Indicators of service sector developments $2003^{1}$

A. Value added shares in services, percentage point deviation from income-adjusted average ${ }^{2}$

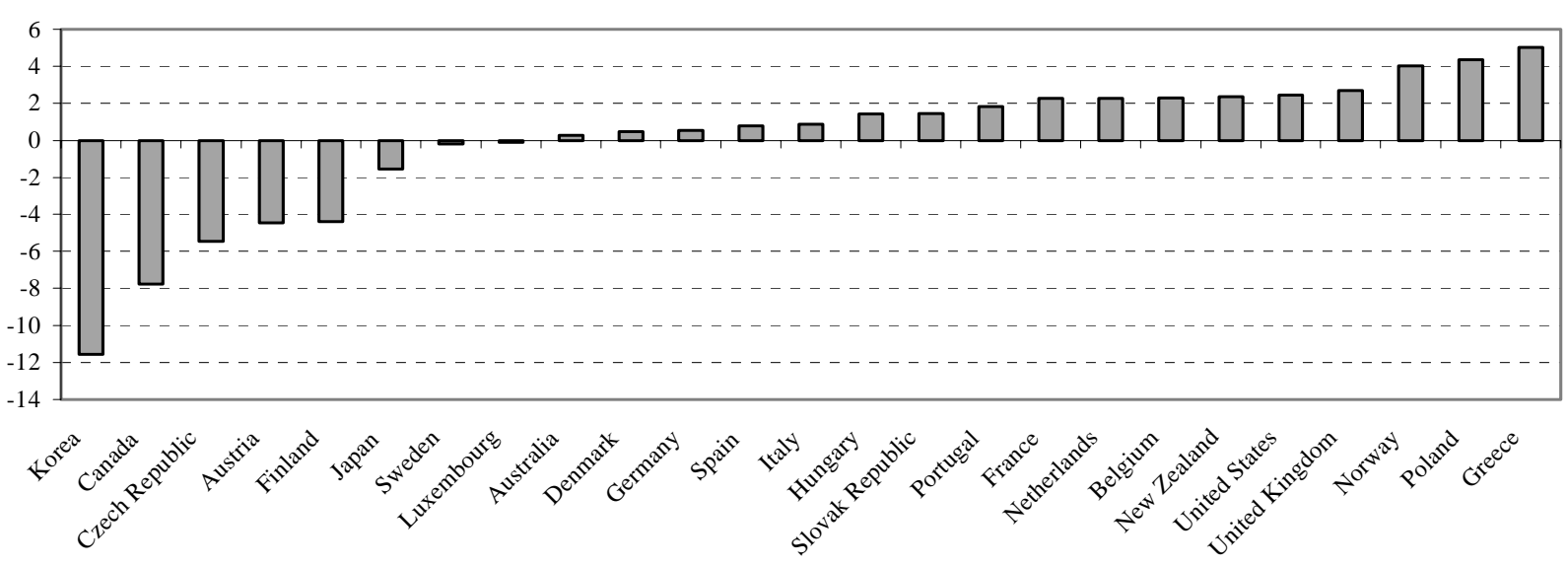

B. Employment shares in services, percentage point deviation from income-adjusted average ${ }^{2}$

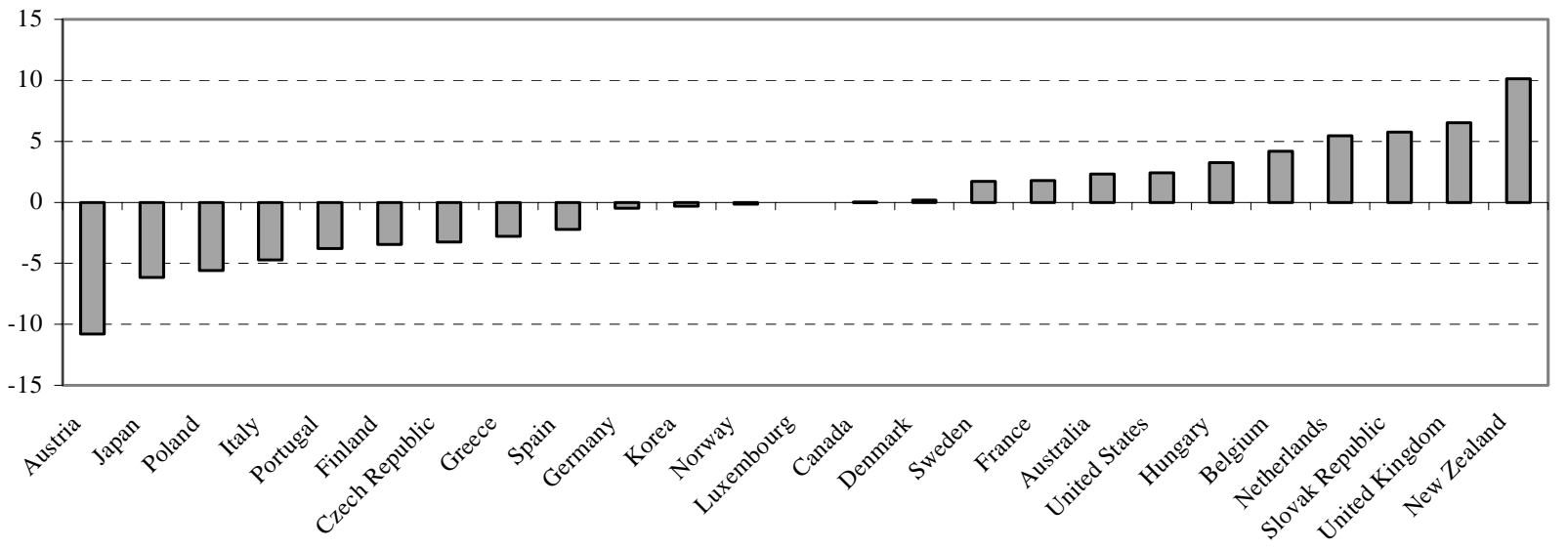

\section{Employment rate in services, per cent ${ }^{3}$}

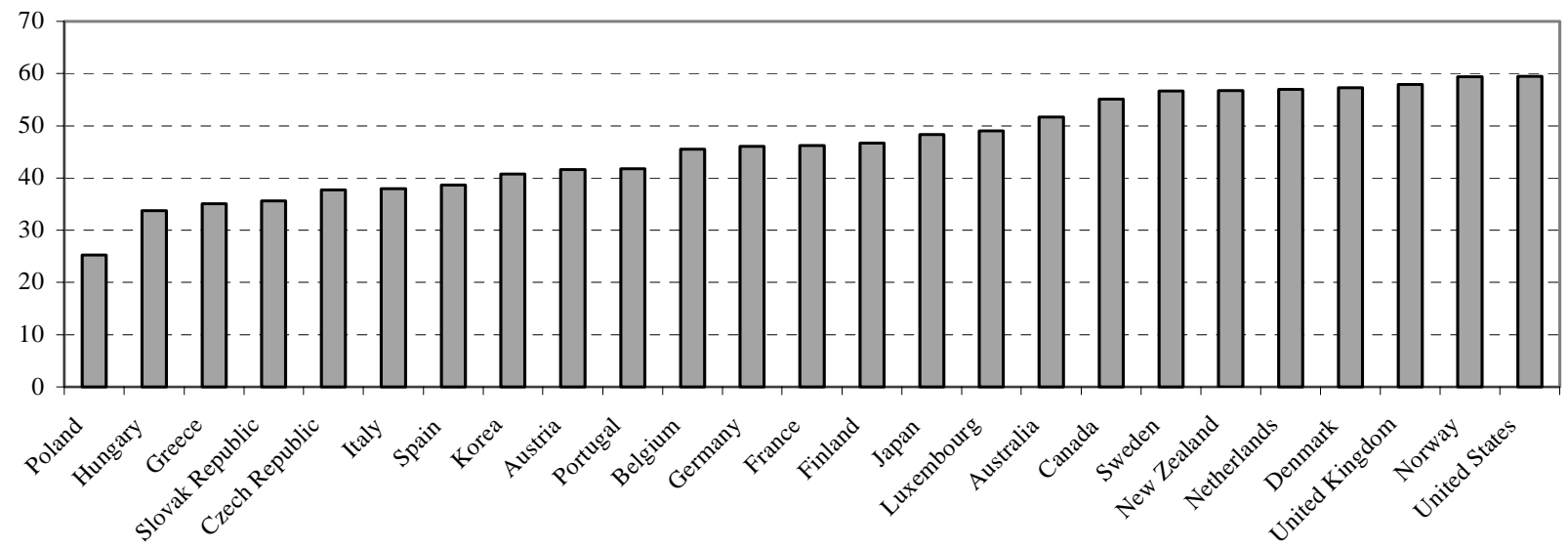

1. Or latest year available. See Appendix 1 for industry classification and data availability.

2. These deviations are based on figure 2.2, panel A and B.

3. The employment rate is calculated as the employment level in services relative to the working-age population.

Source: The OECD STAN Database for Industrial Analysis and OECD Labour Force Statistics. 
18. Taking into account the limitations of the simple indicators presented above, some patterns emerge (Figure 2.7):

- A group of countries seem to combine an above-average capacity to adjust in labour markets with a relatively large income-adjusted service sector. This group includes New Zealand, Norway, the United Kingdom and the United States.

- At the other end of the spectrum, countries that have a below-average performance according to both indicators include Austria, Czech Republic, Germany, Italy, Japan and Poland. In addition, France stands out with a relatively poor ranking on the capacity to adjust in labour markets, but with a relatively large service sector, while Canada combines a high rank on the labouradjustment indicator with a below-average rank on the capacity to develop the service sector.

Table 2.2. Correlations between countries ranking on performance indicators ${ }^{1}$

A. Adjustment capacities for sectoral reallocation

\begin{tabular}{|c|c|c|c|c|c|c|c|}
\hline & $\begin{array}{c}\text { Incidence of } \\
\text { long-term } \\
\text { unemploy- } \\
\text { ment }\end{array}$ & $\begin{array}{l}\text { Outflows } \\
\text { from } \\
\text { unemploy- } \\
\text { ment }\end{array}$ & $\begin{array}{c}\text { Average } \\
\text { job } \\
\text { tenure }\end{array}$ & $\begin{array}{c}\text { Gross } \\
\text { labour flows }\end{array}$ & $\begin{array}{c}\text { Internal } \\
\text { migration }\end{array}$ & $\begin{array}{c}\text { Regional } \\
\text { unemployment } \\
\text { dispersion } \\
\text { (st.dev.) }\end{array}$ & $\begin{array}{c}\text { Regional } \\
\text { unemployment } \\
\text { dispersion } \\
\text { (coef. of var.) }\end{array}$ \\
\hline Incidence of long-term unemployment & 1.00 & 0.86 & 0.46 & 0.14 & 0.70 & 0.66 & 0.32 \\
\hline Outflows from unemployment & & 1.00 & 0.46 & 0.09 & 0.76 & 0.56 & 0.28 \\
\hline Average job tenure & & & 1.00 & -0.07 & 0.30 & 0.17 & 0.22 \\
\hline Gross labour flows & & & & 1.00 & 0.36 & 0.23 & -0.03 \\
\hline Internal migration & & & & & 1.00 & 0.80 & 0.73 \\
\hline Regional unemployment disp. (st.dev) & & & & & & 1.00 & 0.67 \\
\hline Regional unemployment disp. (coef.) & & & & & & & 1.00 \\
\hline
\end{tabular}

\begin{tabular}{lccc}
\hline \multicolumn{3}{l}{ B. Indicator or service sector development } & \\
\hline \multicolumn{2}{c}{ Value-added share } & Employment share & Employment rate \\
\hline Value-added share & 1.00 & 0.36 & 0.05 \\
Employment share & & 1.00 & 0.41 \\
Employment rate & & 1.00 \\
\hline
\end{tabular}

1. The correlations are calculated from the rankings assigned to countries based on the indicators shown in Figure 2.5 and Figure 2.6.

Figure 2.7. Summary of country scores

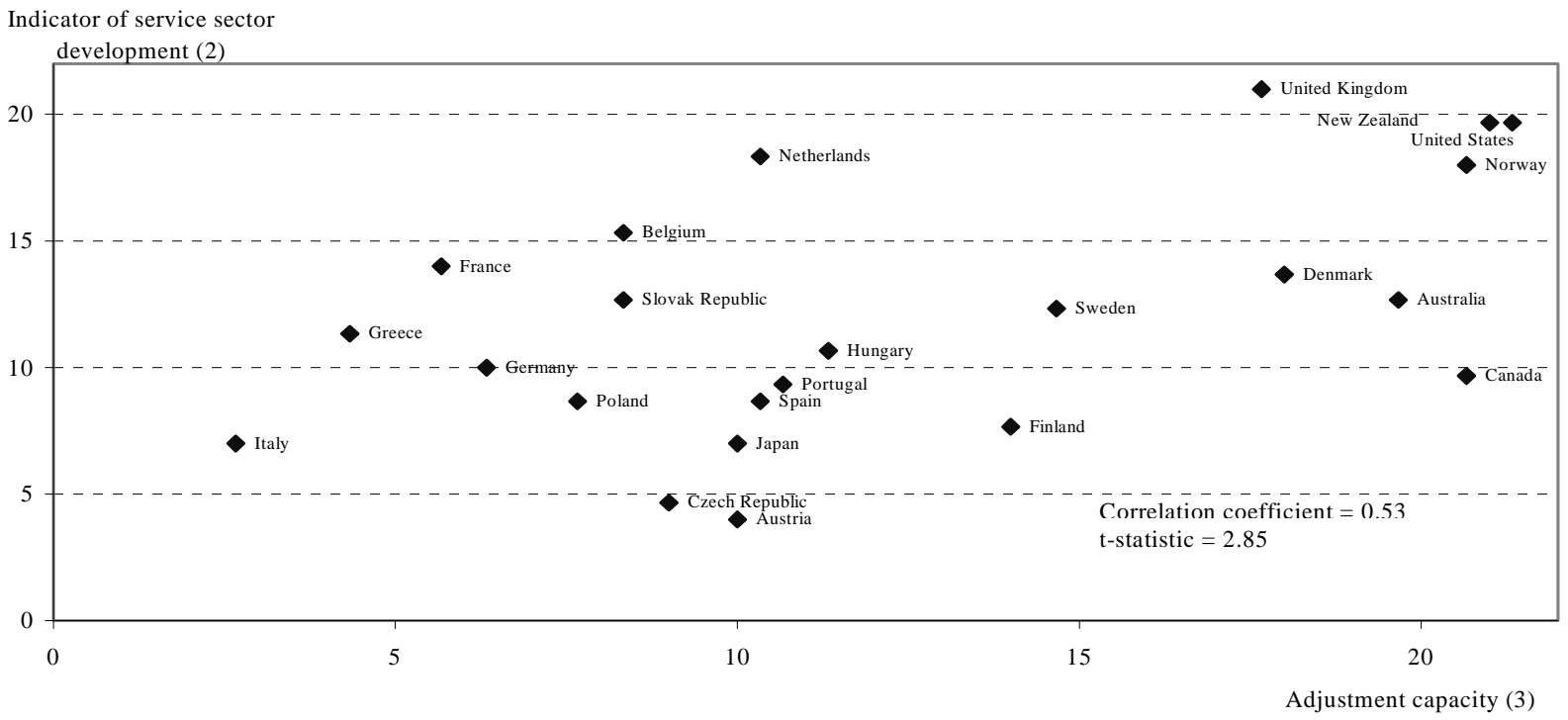

1. The indicators are calculated as follows: Countries are assigned a score from 1 ("the worst") to 23 ("the best") on the indicators shown in Figure 2.5 (only Panels A-C) and Figure 2.6. The two summary indicators are then calculated as an unweighted average of the respective country scores. 


\section{Policies to facilitate adjustment in labour markets}

19. Countries' adjustment capacities are closely linked to the stance of policies that influence the functioning of the labour market. This section reviews the impact of policies in the following areas: reemployment incentives in public benefit schemes, employment protection regulations, wage setting arrangements, education and training policies, housing market policies and taxation. Policy recommendations in the key areas that have already been given to individual countries in the context of peer reviews in the OECD are also briefly referred to in the text and summarised in Appendix 4.

\subsection{Providing appropriate re-employment incentives}

\section{Policies affecting re-employment incentives}

20. Public benefit systems can help facilitate structural change by allowing more time for job matching and by easing public pressures for protectionist policy measures. On the other hand, they may also slow down adjustments to structural change by reducing the incentives of displaced individuals to find gainful employment. Available econometric evidence shows that economic incentives have important effects on transition rates from unemployment to employment, although the overall outcome also depends on the interaction with other policies. One recent micro study found, for example, that a $10 \%$ increase in the unemployment benefit replacement ratio reduces the transition rate from unemployment to employment by around 5\% (Røed and Zhang, 2000).

21. Eligibility criteria in unemployment benefit schemes - including work availability and job search requirements, definition of suitable work and obligations to enter labour market programmes - can, in principle, have a larger impact on behaviour than variations in replacement rates. This is because the economic impact on individuals is much larger. Indeed, the impact of tighter eligibility has generally been found to be significant, with some studies finding more than a doubling of the transition rate to employment (OECD, 2000b). Similarly, transition rates from unemployment to employment have sometimes been found to increase prior to compulsory activation programmes.

22. Employment-conditional benefits and other "make-work-pay" policies (e.g. re-employment bonuses, minimum wages) can speed up adjustment by reducing the marginal effective tax rates associated with moving from benefit to low-paid employment. Experience in Canada, the United Kingdom and the United States shows that employment-conditional benefits have encouraged a return to employment by single parents and members of jobless households (OECD, 2003). Some adverse effects have, however, also been identified. The employment rate of married women with working spouses has been lowered by some programmes, while the working time of other employees may have been reduced because of higher marginal tax rates in the phase-out income range of the benefit.

\section{The level and duration of unemployment benefits}

23. The level and duration of benefits relative to previous earnings differs widely between OECD countries, as summarised by the OECD unemployment benefit indicator (Figure 3.1). In the short run, the net replacement rate for workers earning $100 \%$ of the average production worker is above $80 \%$ of previous earnings in Luxembourg and Sweden, and more than $70 \%$ in Finland, Portugal, France, the Netherlands, Norway, Spain and Switzerland. For long-term unemployed, replacement rates are particularly high in Ireland, at around 100\%, and close to 70\% in Denmark, Finland, Germany and the Slovak Republic. 
Figure 3.1. Net replacement rates in unemployment benefit schemes

Relative to previous earnings, per cent, $2002^{1}$

A. Initial replacement rate for workers earning $100 \%$ of the average production worker

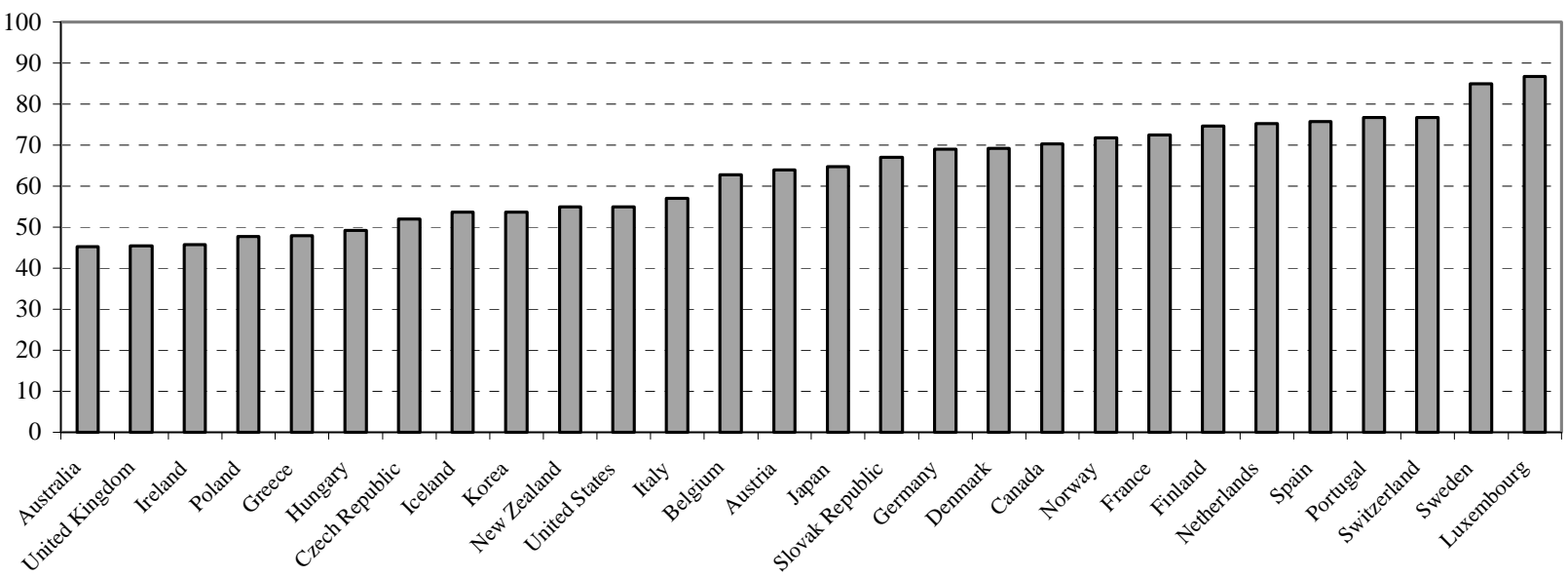

B. Long-term replacement rate for workers earning $100 \%$ of the average production worker

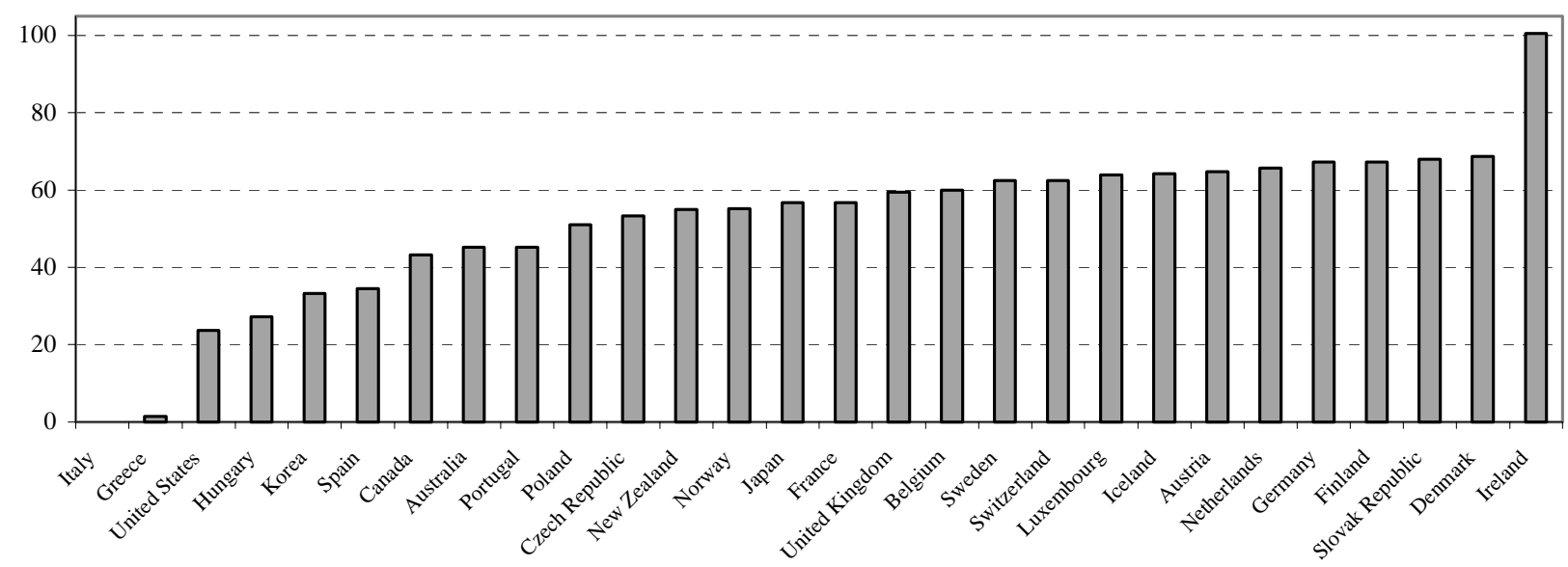

1. Simple average of four family types: single, married couple, couple with two children and lone parent with two children. The initial replacement rate refers to the first month of benefit recipients, while the long-term replacement rate refers to the 60th month of benefit recipients.

Source: Benefits and Wages, OECD Indicators.

24. Displaced workers may, however, not be able to find new employment at the same pay as they received in the previous job. Net replacement benefits relative to potential earnings in a new job - which provides a better measure of displaced workers' re-employment incentives - can therefore be even higher than illustrated above. There are two main reasons for this. First, workers that have to change industry to find new employment may no longer capitalise on accumulated sector-specific skills, reducing their productivity and potential earning in a future job. Second, different industries tend to pay very different wages to workers with roughly similar skills and other characteristics (Jean and Nicoletti, 2002), possibly reflecting rents originating in weak product market competition and workers' bargaining power in different industries. In general, net replacement rates can be quite high for workers moving from declining manufacturing industries to expanding service activities when differences in the sectoral wage premiums are taken into account (Figure 3.2). Using Austria, Denmark and France as examples, displaced workers from declining industries could easily face replacement rates close to or above $90 \%$ relative to their potential earning in expanding destination sectors (Table 3.1). 
Figure 3.2. Net replacement rate in unemployment benefit schemes

For a worker moving from manufacturing to services, per cent ${ }^{1}$

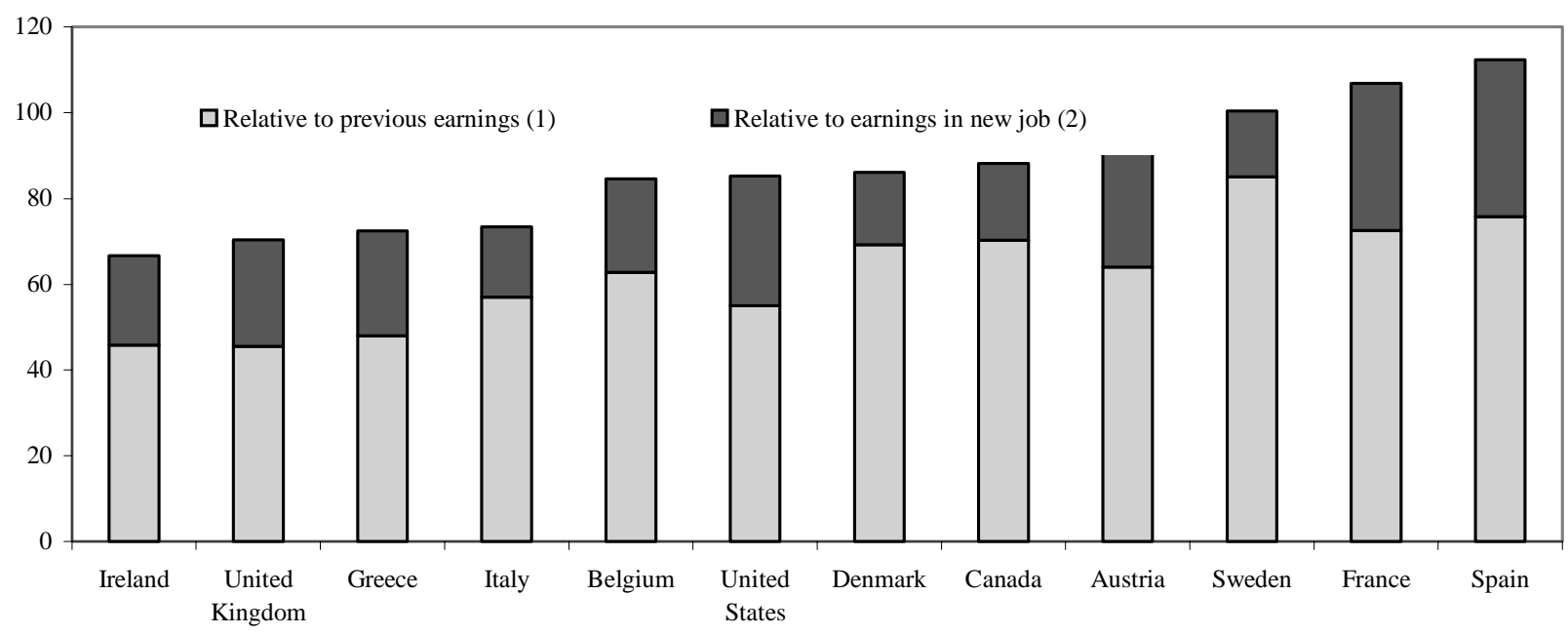

1. Initial net replacement rate for workers earning $100 \%$ of the average production worker.

2. These calculations are illustrative only. The net replacement rate relative to earnings in a new job is calculated as the sum of two components: i) the initial net replacement rate relative to previous earning in 2002 for workers earning $100 \%$ of the average production worker, and ii) the estimated loss in wage premia associated with a move from manufacturing to services (based on the average wage premia in the three manufacturing/service industries with highest/lowest wage premia).

Source: OECD Indicators on Benefits and Wages and Jean and Nicoletti (2002).

25. Replacement rates relative to potential earnings in new employment can be especially high for older job losers. One reason for this is that high-tenured workers often experience larger wage losses than other workers upon re-employment (Jacobson et al., 1993). The wage loss seems to be particularly pronounced for high-tenured blue-collar workers, further adding to the problems of re-integrating displaced manufacturing workers (Kletzer, 1989). However, available studies suggest important differences between countries (Table 3.2), although these could reflect, in part, differences in data sources and methods. While relatively large wage losses are found in the United States, Belgium, Canada and the United Kingdom, no wage losses are identified in mass lay-offs in France and Germany. These findings may indicate important variations in re-employment incentives between countries (smaller wage losses implying better employment incentives), but could also stem from a selection bias as countries' capacities to re-integrate displaced workers differ (i.e. if not re-employed, no wage loss is registered).

26. In addition, re-employment incentives of older workers are adversely affected by various explicit or de facto early retirement programmes offering high replacement rates. Unemployment benefits are, for instance, often of longer duration and subject to less stringent job-search requirements for older workers (OECD, 2000b). Furthermore, early-retirement and disability pension schemes provide possible routes out of the labour force, and replacement rates in these schemes are often high. ${ }^{11}$

11. High replacement rates in old-age and early retirement schemes have been shown to have sizeable effects on the departure of workers from the labour force (see e.g. Duval, 2003). 
Table 3.1. Net replacement rates for workers moving from declining to expanding industries In per cent of earnings in the new job, $2002^{1}$

\begin{tabular}{|c|c|c|c|c|c|c|c|}
\hline & $\begin{array}{l}\text { Employed } \\
\text { persons (in } \\
\text { thousands) } \\
\end{array}$ & $\begin{array}{c}\text { Employment } \\
\% \text { change, } \\
1990-02 \\
\end{array}$ & $\begin{array}{c}\text { Hotels \& } \\
\text { Restaurants } \\
\end{array}$ & $\begin{array}{c}\text { Land } \\
\text { transport }\end{array}$ & $\begin{array}{c}\text { Retail } \\
\text { trade }\end{array}$ & $\begin{array}{c}\text { Other } \\
\text { business } \\
\text { services }\end{array}$ & $\begin{array}{c}\text { Wholesale } \\
\text { trade }\end{array}$ \\
\hline \multicolumn{8}{|l|}{ A. France } \\
\hline Wood & 91 & -20.2 & 123.5 & 111.2 & 108.8 & 92.6 & 91.8 \\
\hline Coke, Petroleum & 32 & -46.7 & 111.9 & 100.7 & 98.5 & 83.9 & 83.1 \\
\hline Chemicals & 222 & -15.6 & 101.1 & 91.0 & 89.0 & 75.9 & 75.2 \\
\hline Other transport equipment & 121 & -14.8 & 95.8 & 86.2 & 84.3 & 71.8 & 71.2 \\
\hline Printing \& Publishing & 234 & -10.7 & 93.1 & 83.8 & 82.0 & 69.8 & 69.2 \\
\hline Medical and optical instruments & 131 & -9.7 & 92.2 & 83.0 & 81.2 & 69.1 & 68.5 \\
\hline Machinery \& equipment & 309 & -13.4 & 89.5 & 80.6 & 78.8 & 67.1 & 66.5 \\
\hline Fabricated metal & 434 & -8.8 & 85.9 & 77.3 & 75.7 & 64.4 & 63.9 \\
\hline Motor vehicles & 264 & -11.4 & 77.0 & 69.3 & 67.8 & 57.7 & 57.2 \\
\hline Employed persons (in thousands) & & & 862 & 652 & 1773 & 2338 & 1130 \\
\hline Employment, \% change, 1990-02 & & & 16.0 & 4.7 & 6.6 & 57.9 & 8.9 \\
\hline \multicolumn{8}{|l|}{ B. Austria } \\
\hline Coke, Petroleum & 2 & -45.7 & 132.6 & 98.7 & 97.7 & 94.7 & 90.1 \\
\hline Electrical machinery & 29 & -17.0 & 105.1 & 78.3 & 77.5 & 75.1 & 71.5 \\
\hline Printing \& Publishing & 28 & -16.3 & 103.3 & 76.9 & 76.1 & 73.8 & 70.2 \\
\hline Radio, television & 31 & -19.7 & 103.3 & 76.9 & 76.1 & 73.8 & 70.2 \\
\hline Chemicals & 30 & -10.5 & 101.5 & 75.6 & 74.8 & 72.5 & 69.0 \\
\hline Instruments, Watches & 15 & -15.9 & 97.8 & 72.9 & 72.1 & 69.9 & 66.5 \\
\hline Non-metallic mineral & 36 & -14.5 & 97.8 & 72.9 & 72.1 & 69.9 & 66.5 \\
\hline Basic metals & 33 & -25.8 & 97.8 & 72.9 & 72.1 & 69.9 & 66.5 \\
\hline Machinery \& equipment & 81 & -2.9 & 96.9 & 72.2 & 71.4 & 69.2 & 65.9 \\
\hline Employed persons (in thousands) & & & 257 & 151 & 306 & 239 & 213 \\
\hline Employment \% change, $1990-02$ & & & 17.2 & 3.2 & 11.9 & 75.8 & 11.1 \\
\hline \multicolumn{8}{|l|}{ C. Denmark } \\
\hline Coke, Petroleum & 1 & -12.5 & 86.6 & 92.6 & 88.5 & 78.8 & 77.3 \\
\hline Printing \& Publishing & 39 & -16.1 & 84.3 & 90.2 & 86.2 & 76.8 & 75.3 \\
\hline Instruments, Watches & 15 & -5.6 & 75.3 & 80.5 & 76.9 & 68.6 & 67.2 \\
\hline Pulp \& Paper & 8 & -31.9 & 73.8 & 78.9 & 75.4 & 67.2 & 65.9 \\
\hline Non-metallic mineral & 18 & -12.9 & 72.3 & 77.3 & 73.9 & 65.8 & 64.5 \\
\hline Food \& Beverages & 76 & -16.0 & 70.8 & 75.7 & 72.3 & 64.5 & 63.2 \\
\hline Other transport equip. & 9 & -37.2 & 70.0 & 74.9 & 71.6 & 63.8 & 62.5 \\
\hline Machinery \& equipment & 66 & -15.4 & 69.3 & 74.1 & 70.8 & 63.1 & 61.9 \\
\hline Fabricated metal & 45 & -14.5 & 68.5 & 73.3 & 70.0 & 62.4 & 61.2 \\
\hline Employed persons (in thousands) & & & 83 & 70 & 201 & 191 & 176 \\
\hline Employment \% change, $1990-02$ & & & 26.0 & -4.3 & 12.9 & 53.7 & 8.8 \\
\hline
\end{tabular}

1. These calculations are illustrative only. The net replacement rate relative to earnings in a new job is calculated as the sum of two components: i) the initial net replacement rate relative to previous earnings in 2002 for workers earning $100 \%$ of the average production worker (72.5\% in France, $64.0 \%$ in Austria and 69.3\% in Denmark), and ii) the estimated loss in wage premia associated with a change of sector. The shaded areas indicate transitions involving losses in wage premia. Source: OECD indicators on Benefits and Wages and Jean and Nicoletti (2002). 
ECO/WKP(2005)14

Table 3.2. Job displacement and wage losses ${ }^{1}$

\begin{tabular}{|c|c|c|}
\hline Author & Data & Findings \\
\hline $\begin{array}{l}\text { Farber } \\
(2003)\end{array}$ & $\begin{array}{l}\text { The US Displaced } \\
\text { Workers Surveys (1981- } \\
\text { 2001) }\end{array}$ & $\begin{array}{l}\text { - Re-employed workers in full-time jobs experienced an average wage loss of } 8 \% \text {, } \\
\text { although with a strong cyclical pattern. } \\
\text { - Significantly higher wage losses for workers with long job tenure. } \\
\text { - No statistically significant difference in wage losses between educational groups. }\end{array}$ \\
\hline $\begin{array}{l}\text { Lefranc } \\
(2003)\end{array}$ & $\begin{array}{l}\text { The French Employment } \\
\text { Surveys (1990-97) and the } \\
\text { US Panel Study of Income } \\
\text { Dynamics (1983-1992) }\end{array}$ & $\begin{array}{l}\text { - Wage losses in the order of } 10-15 \% \text { in both France and the US. } \\
\text { - While a loss of firm-specific earnings potential was the main factor in France, } \\
\text { lower quality job matches were of most importance in the United States. }\end{array}$ \\
\hline $\begin{array}{l}\text { Kuhn }(e d s .) \\
(2002)\end{array}$ & $\begin{array}{l}\text { Belgium, Canada, } \\
\text { Denmark, France, } \\
\text { Germany, Japan, UK, US }\end{array}$ & $\begin{array}{l}\text { - Long-tenured workers: } \\
\text { - An average wage loss of } 19 \% \text { in the US, } 11 \% \text { in Canada, } 6 \% \text { in the UK and } \\
\text { Belgium and } 1 \% \text { in Denmark (only mass layoffs for Denmark). } \\
\text { - An average wage increase for workers displaced in mass layoffs of } 10 \% \text { in } \\
\text { France and } 2 \% \text { in Germany. However, workers remaining unemployed for } \\
\text { more than a year before re-employment experienced wage losses. } \\
\text { - Older workers experienced greater wage losses; no significant effect of } \\
\text { education. }\end{array}$ \\
\hline $\begin{array}{l}\text { Kletzer } \\
(2001)\end{array}$ & US (1980s and 1990s) & $\begin{array}{l}\text { - Two-thirds of workers who lost jobs in manufacturing industries hit by overseas } \\
\text { competition earned less on their next job, and a quarter experienced income } \\
\text { losses of } 30 \% \text { or more. } \\
\text { - Larger wage losses in manufacturing (12\%) than in non-manufacturing }(4 \%) \text {. }\end{array}$ \\
\hline $\begin{array}{l}\text { Jacobson et } \\
\text { al. (1993) }\end{array}$ & $\begin{array}{l}\text { Data from Pennsylvania, } \\
\text { US (1974-96) }\end{array}$ & $\begin{array}{l}\text { - Average long-term earning losses of } 23 \% \text { for long-tenured workers. } \\
\text { - Displacements from unionized sectors (construction, metals, transport) } \\
\text { associated with larger wage losses than displacements from non-unionized } \\
\text { industries (business and professional services). }\end{array}$ \\
\hline
\end{tabular}

1. These estimates do not take into account lower income during unemployment, income losses due to re-employment in part-time work or foregone earnings in terms of wage growth.

Source: As indicated in table.

\section{Countries' strategies to improve re-employment incentives}

27. There are several different strategies that could be adopted to improve re-employment incentives for displaced workers - in particular: cutting benefit levels and duration; tightening eligibility criteria in the relevant schemes; and using "make-work-pay" policies more extensively. OECD countries have in general been reluctant to lower benefit levels and reduce duration in unemployment benefit schemes, although some adjustments have taken place in recent years in Denmark, Hungary, Ireland, Poland, Slovak Republic and Spain (Brandt et al., 2005). In some countries, benefits have recently been made less dependent on previous income, thus lowering replacement rates for individuals with relatively high pay in their previous job (e.g. Germany). However, unemployment benefits sometimes depend positively on regional unemployment rates (e.g. Poland), reducing incentives for unemployed workers to move to another region.

28. Eligibility conditions have been tightened in most OECD countries during the past decade, including requirements regarding job search, work availability and participation in training programmes (Brandt et al., 2005). This has often taken place in the context of increased emphasis on the activities of unemployed workers (e.g. Denmark and the United Kingdom). In most countries, non-compliance by refusing work offers or failing to attend interviews may result in benefit sanctions, usually in the form of a benefit stop of defined duration. However, in many countries sanctions do not apply if the work involves a change of occupation, lower earnings, lengthy commuting times or geographic mobility. Eligibility conditions are also sometimes easier in regions with high unemployment levels (e.g. Canada). In the late 
1990s, the incidence of unemployment benefit refusals and sanctions during the benefit period varied from close to zero in Japan, New Zealand and Germany to $40 \%$ of the average stock of beneficiaries in Switzerland and close to $60 \%$ in the United States (Figure 3.3). However, the sanctions applied differ considerably across countries (e.g. the size and length of the benefit sanction), and seems to be relatively light in the United States.

29. Most OECD countries have introduced or extended "make-work-pay" policies in recent years to increase the financial incentives to become re-employed. Employment-conditional benefits have been used for a long time in the United Kingdom and the United States, and have more recently been adopted in a number of OECD countries (including Belgium, Finland, the Netherlands and France). These programmes are usually targeted at low income families (OECD, 2003), particularly those with children, and may not reach all displaced workers. However, adjustment programmes aimed at encouraging displaced workers to quickly search for and accept new jobs are also used in some countries. The Trade Promotional Authority Act of 2002 in the United States introduced, for instance, a form of wage insurance for older workers who have been displaced because of trade. This programme strengthens re-employment incentives as payments start as soon as the worker takes a new job and stop two years from the date the worker was laid off. ${ }^{12}$

Figure 3.3. Sanctions for behaviour during benefit period

Total sanctions in a year in per cent of the average stock of beneficiaries, late 1990s

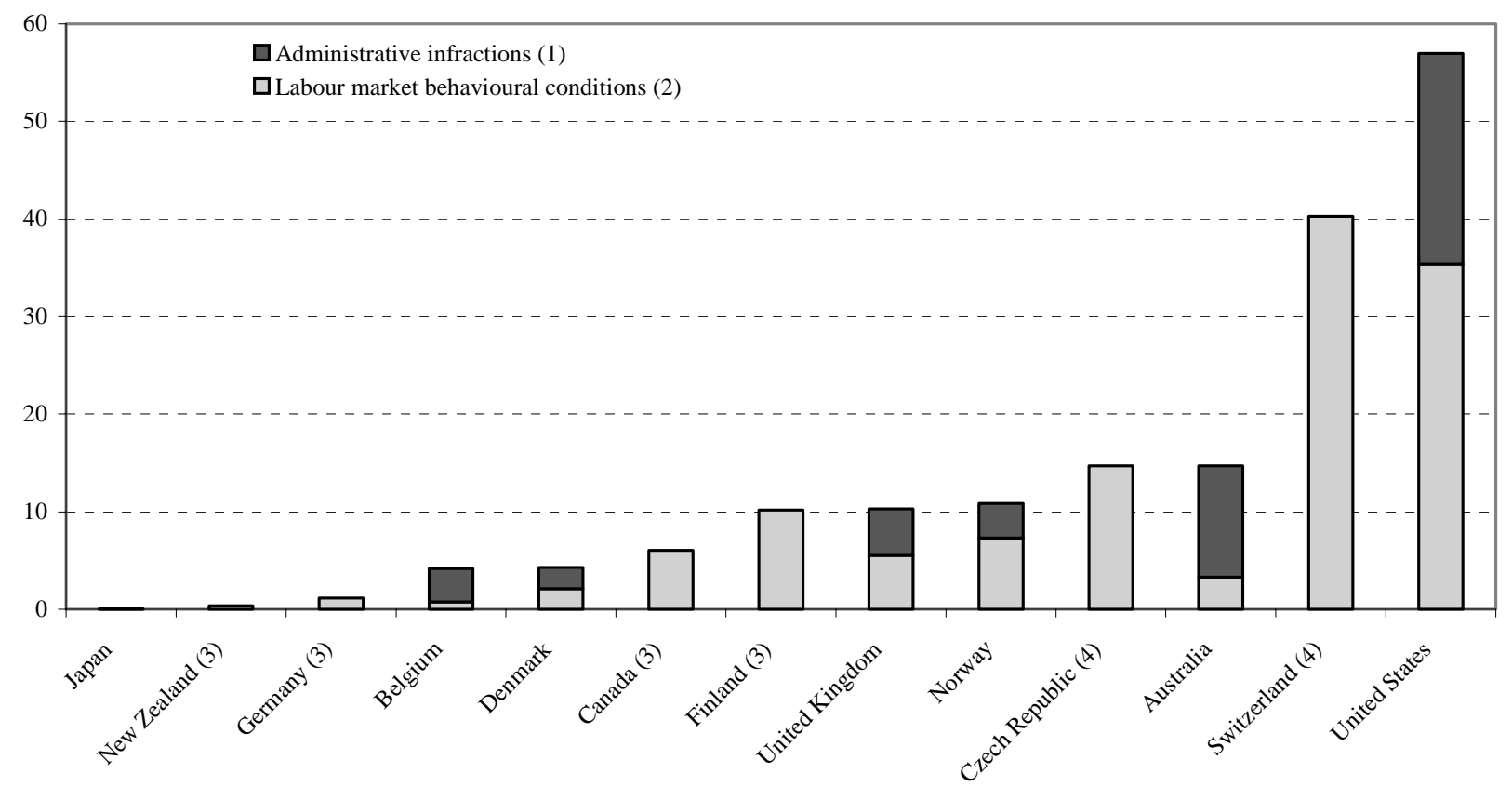

1. Includes for instance refusal of work and failures to provide evidence of active job search.

2. Refer to non-attendance at interviews with the PES and failure to send necessary forms or notify changes in circumstances.

3. No data available on sanctions and refusals due to administrative infractions.

4. Data refers to total sanctions and refusals.

Source: OECD Employment Outlook 2000, Chapter 4.

12. Under this scheme, workers re-employed in jobs paying less than they earned on their prior job receive a benefit equalling one-half of the reduction in earnings, up to an annual ceiling of $\$ 10000$. 


\section{An unfinished agenda}

30. Peer reviews of OECD countries have recommended a number of specific actions that, while typically presented in the context of wider labour-market concerns, would facilitate labour re-allocation. These include measures to improve labour-supply incentives in unemployment benefit schemes by reducing replacement rates (Belgium, Czech Republic, Denmark, Iceland, Luxembourg, the Netherlands, Norway, Poland and Sweden) or tightening eligibility criteria (Australia, Austria, Canada, Finland, France, Germany, Spain and Switzerland). Several countries have also received a recommendation to curtail early retirement through special schemes or through the disability benefit system (including Australia, Japan, Norway, Switzerland and most EU member countries). Acting on such recommendations should limit the risk that job losses, including those as a result of falling manufacturing employment, would result in long unemployment spells or withdrawals from the labour market.

\subsection{Avoiding overly strict employment protection}

\section{The impact of employment protection on countries' capacity to adjust}

31. A certain degree of employment protection may facilitate structural adjustments by providing transparent procedures and time for all interested parties to plan and implement necessary adjustments. However, available econometric evidence suggests that strict employment protection legislation (EPL) significantly reduces the speed of adjustment to structural changes. For firms, strict EPL and uncertainties about adjustment costs may constrain their ability to cope with a rapidly changing environment, resulting in both lower job destruction and job creation rates. This may increase adjustment costs for displaced workers, as lower flows out of unemployment reduce re-employment probabilities and lengthen unemployment spells. ${ }^{13}$

32. Moreover, workers' incentives to change employer are likely to be negatively affected by strict employment protection, resulting in lower voluntary job mobility (Gómez-Salvador et al., 2004). This is because workers usually have to stay with the same employer for a certain length of time (e.g. three or five years) before being eligible to full employment protection, including the rights to severance pay in the event of dismissal. Widespread use of temporary contracts in several countries may also divide the labour market into segments providing different levels of protection. This may further reduce the incentives for workers on permanent contracts to change employer, although it may also ease adverse effects of EPL on employers' hiring incentives. For the inactive population, recent evidence also suggests that strict employment protection can impede work possibilities of youth and prime-age women (OECD, 2004a), with possible detrimental effects on industries relying disproportionately on such labour groups.

33. The impact of overly strict employment protection is likely to differ across industries. It could hold back expanding activities, thus obstructing the shift to services (Nickell et al., 2004). The impact could be especially detrimental for service industries with particular needs for flexibility, for instance due to large variations in demand or because developing new services involves a lot of experimentation and uncertainty. Recent econometric work suggests that the producer services sector is particularly vulnerable to strict employment protection (Figure 3.4) ${ }^{14}$ However, very small service firms are usually exempt from EPL legislation as such regulations typically is only applicable above certain size threshold levels. This reduces the impact of employment protection regulations on small service firms, but may also discourage them from growing above the threshold level.

13. See e.g. Blanchard and Portugal (2001) and Caballero et al. (2004). However, more displaced workers seem to be moved directly into new jobs in countries with strict EPL (Kuhn, 2002).

14. See e.g. OECD (2000c) for recent econometric evidence on the impact of employment protection regulation on employment in producer services. 
Figure 3.4. Employment protection and employment in producer services $2003^{1}$

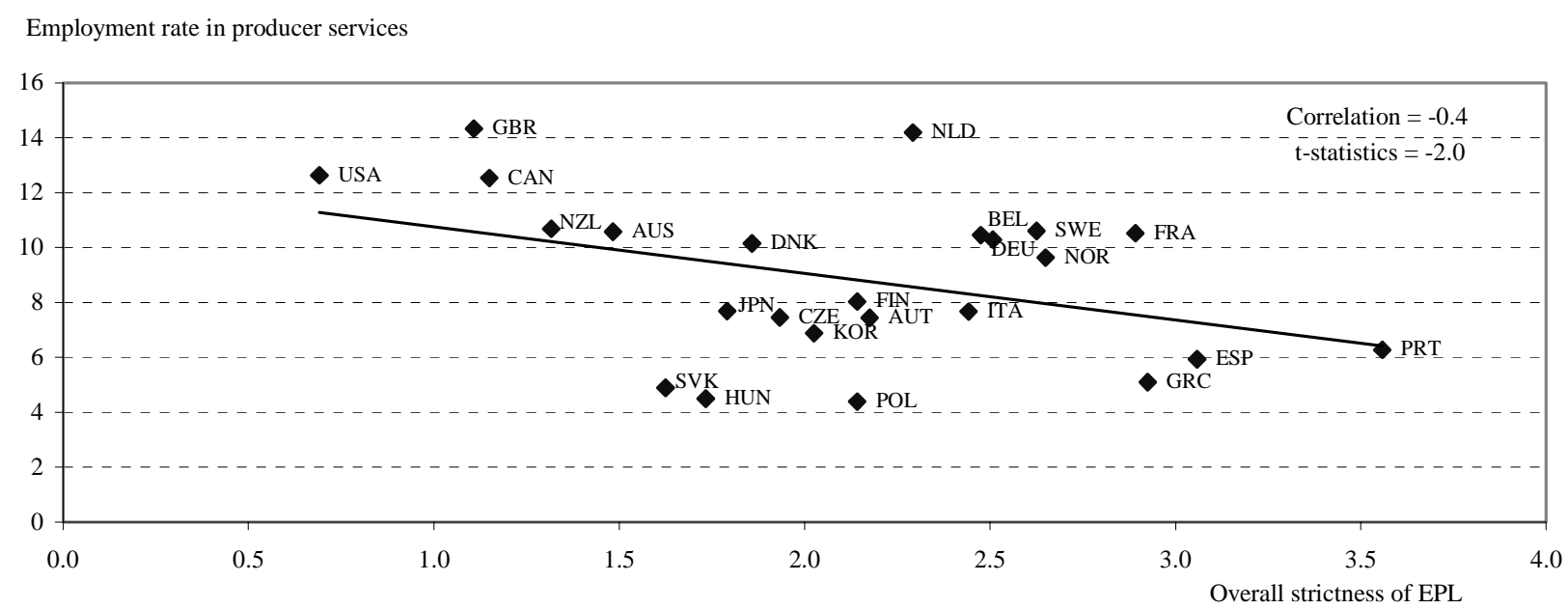

1. Or latest year available. See Appendix 1 for industry classification and data availability.

Source: OECD Employment Outlook, Chapter 2, and the OECD STAN Database for Industrial Analysis and Groningen Growth and Development Centre Database.

\section{The extent of employment protection legislation in OECD countries}

34. The stance of employment protection legislation varies considerably across countries. Job protection is particularly strict in France, Greece, Mexico, Portugal, Spain and Turkey (Figure 3.5). In these countries, employment protection is relatively high for both regular and temporary workers. In some other countries, strong regulation for regular workers coincides with relatively weak controls on the use of temporary contracts (the Czech Republic, Japan, the Netherlands and the Slovak Republic), while others combine easier job protection of workers with permanent contracts with strict regulations of temporary contracts (e.g. Belgium). Other available evidence confirms that firing costs are high in several OECD countries, and that they are sometimes difficult for firms to estimate ex ante. ${ }^{15}$

\section{Countries' strategies to ease the adverse effects associated with strict EPL}

35. Countries have taken different approaches to ease the adverse effects associated with strict EPL. While protection for permanent workers has remained virtually unchanged, the use of temporary contracts has been liberalised in several OECD countries in recent years, including Belgium, Italy, Greece, Germany and the Netherlands (Brandt et al., 2005). A few OECD countries have also tried to reduce the uncertainties for firms associated with restructuring, without necessarily reducing job protection for workers. In Japan, for example, rules governing dismissal for economic and other reasons have been recently clarified, thereby curtailing the discretion of labour courts (OECD, 2004b). Furthermore, one OECD country (Austria) has recently transformed the severance pay system into a system of individual savings accounts, thus moving a large part of firms' adjustment costs into ongoing monthly labour costs

15. In France, for example, the average cost of dismissal of a worker has been estimated at around six months of the annual labour cost (Abowd and Kramarz, 1997), while estimates for Italy range from two weeks to 20 months in case of conflict (Del Boca and Rota, 1998). In Germany and France, around one-quarter of all layoffs are brought before the court, with an average length of procedure of three to four months in Germany and about one year in France (OECD, 2004a). In comparison, only 1\% of all layoffs end up in court in Australia and even fewer in the United States. 
(OECD, 2004a). This reduces firms' adjustment costs at the margin, while removing an important impediment to labour mobility as the individual saving accounts are transferable across employers.

Figure 3.5. Employment protection legislation (EPL)

Indicator of overall stance and contribution from different aspects, 2003

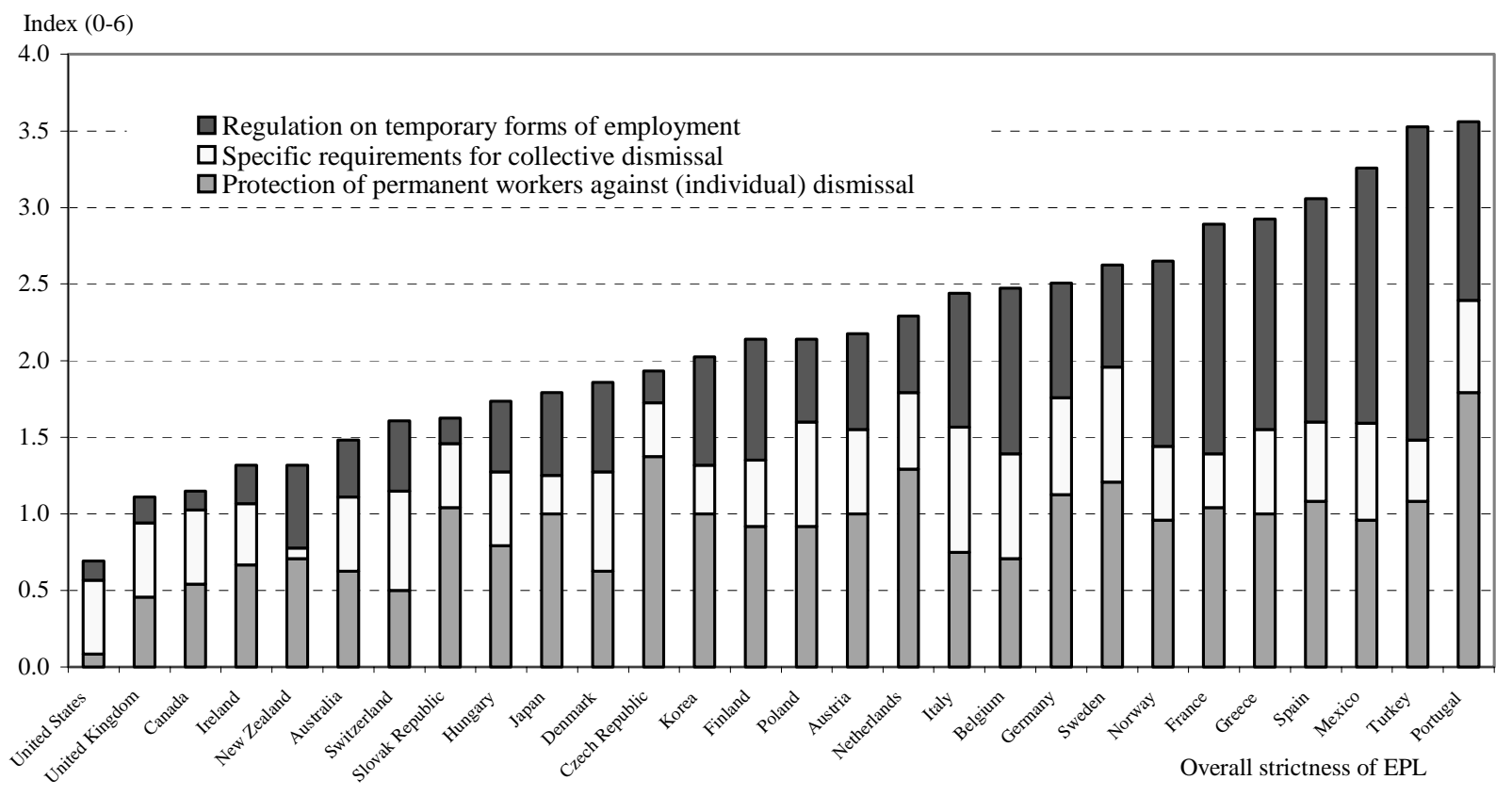

1. Index 0-6 scale from least to most restrictive.

Source: OECD Employment Outlook 2004, Chapter 2.

\section{Recommendations given in recent OECD peer reviews}

36. An easing of employment protection regulations has recently been recommended to strengthen adjustment capacities for several countries in peer-reviews in the OECD, including Australia, Japan, Korea, Mexico and the majority of European member countries (Austria, Belgium, the Czech Republic, France, Germany, Greece, Italy, Luxembourg, the Netherlands, Norway, Poland, Portugal, the Slovak Republic, Spain, Sweden and Turkey).

\subsection{Ensuring sufficient wage flexibility}

The capacity of different wage-setting systems to facilitate structural adjustments

37. Flexible wage-setting systems can facilitate structural adjustment by helping to keep labour resources fully utilised and providing signals to workers in respect of moving to the employment where their productivity is highest and improving their human capital. Evidence shows that the flexibility of wages differs across the main bargaining systems:

- Nationwide centralised bargaining systems may deliver low unemployment in a shock-free environment and can deal effectively with macroeconomic shocks, but they are sometimes associated with rigid relative wage structures (OECD, 2004c). This can hamper adjustment when structural change involves changes in the geographical pattern of production or in the relative demand of different skills. 
- Industry-based bargaining systems could more easily result in wage differentiation across sectors, but may have the same disadvantage as centralised systems in responding to structural change with different regional impacts. They may also risk responding poorly to macroeconomic shocks (Calmfors and Driffill, 1988).

- Decentralised wage-setting systems tend to be more responsive to market forces and hence permit swifter changes in relative wages during periods of structural change. They may also retain some of the strengths of centralised bargaining if combined with sufficient co-ordination. Decentralised bargaining is, however, no guarantee for an efficient allocation of resources. For instance, if barriers to labour mobility exist, decentralised bargaining may result in persistent differences in real earnings for similar work across firms and regions, thus enabling less efficient firms to remain in operation. Non-portability of pension rights can, in this context, discourage long-tenured workers from changing employer and thus result in an inefficient utilisation of available labour resources (Box 2).

38. Displaced low-skilled workers could be particularly affected by insufficient wage flexibility as too high wage floors, either established in bargaining or by statute, may prevent them from finding new employment. At the same time, a compressed wage structure could obstruct developments in expanding service activities relying on low-skilled labour. Recent econometric research has, for instance, identified a significant negative effect of centralised bargaining, with its typically high wage floors, on service sector employment, especially in the retail trade sector (Messina, 2004; OECD, 2000c).

\subsubsection{Wage-setting and industrial relations}

39. The characteristics of collective wage-setting systems and industrial relations differ widely among OECD countries, as measured by a number of indicators (Figure 3.6). The Nordic countries and Belgium stand out with relatively high union density rates, as well as a high degree of centralisation and/or co-ordination in wage bargaining. In a few countries with predominantly industry-based wage bargaining, the coverage rate of collective agreements substantially exceeds the union density rate (e.g. Austria, France, Luxembourg, Portugal and Spain), reflecting extensions of collective wage agreements to nonunionised areas of the relevant sectors. Decentralised wage-setting systems, combining the absence of legal extensions of collective contracts, low degree of centralisation and little co-ordination of collective wage bargaining are mainly found in English-speaking countries.

\section{Box 2. Portability of pension rights}

In several OECD countries, pension schemes are not always fully portable from one employer to another. There are three main reasons for this. First, workers often have to stay with the same employer for a certain time period to avoid losing all their pension rights when changing job (e.g. three, five or seven years). Second, defined benefit schemes are frequently back-loaded, i.e. with disproportionately large employer contributions in later years of employment. This implies that workers who leave prior to retirement may give up a large share of their potential pension benefit. Finally, although firms usually offer a lump sum payment to individuals who leave, these lump sums are often insufficient to cover the full losses in pension value.

As a consequence, the value of pension benefit can be substantially lower for workers who have changed employer, interrupted their working life or moved country. In Japan, for example, the loss of pension rights can reach 10-20 million yen for an average pension of 35 million yen depending on the age at separation (OECD, 2004b). Also, in the United Kingdom, a worker who changes employer five times could end up with a pension $30 \%$ lower than someone who remains with the same employer throughout their working life (Blake and Orszag, 1997). 
Figure 3.6. Indicators of wage setting and industrial relations

A. Trade union density, per cent, $2001^{1}$

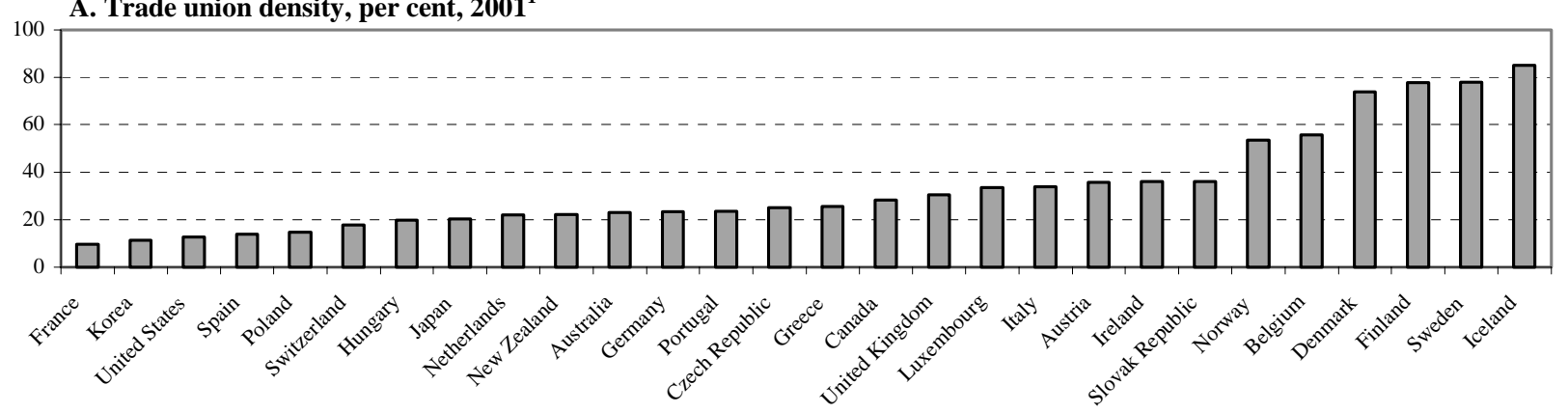

B. Collective bargaining coverage, per cent, $2001^{1}$

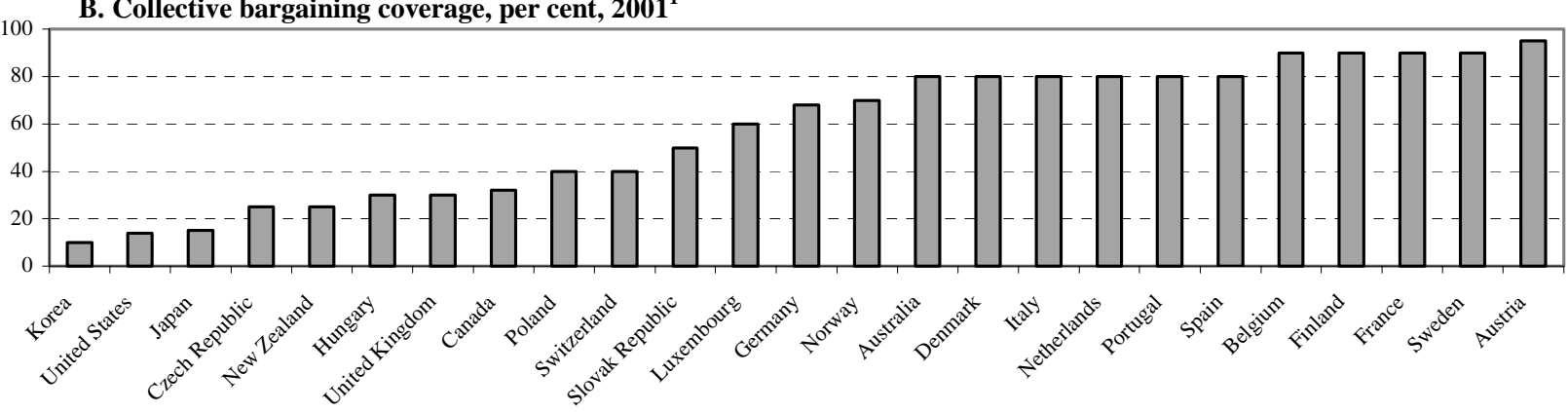

C. Degree of centralisation, $1995-2000^{2}$

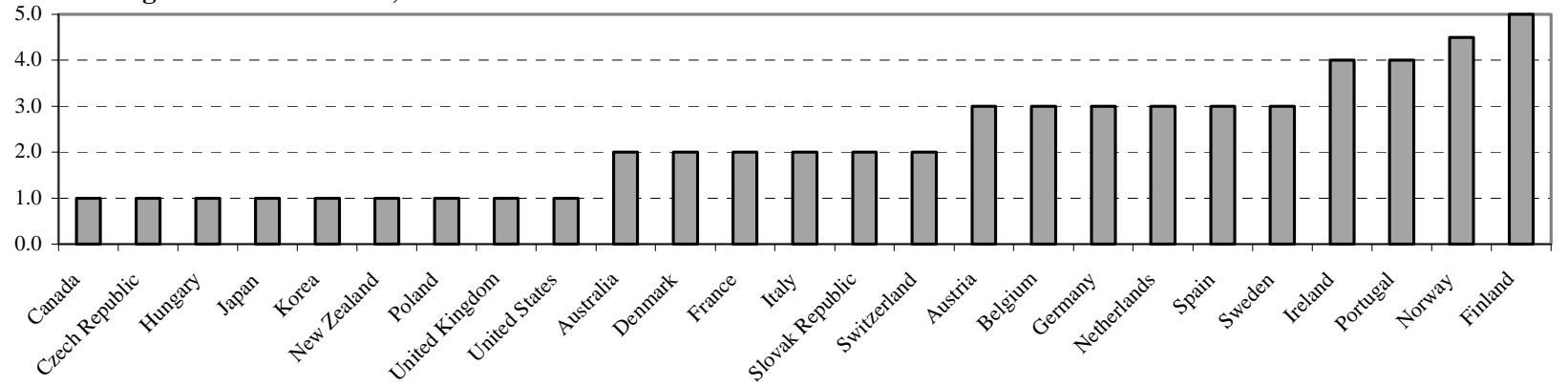

D. Coordination of wage bargaining, $1995-2000^{3}$

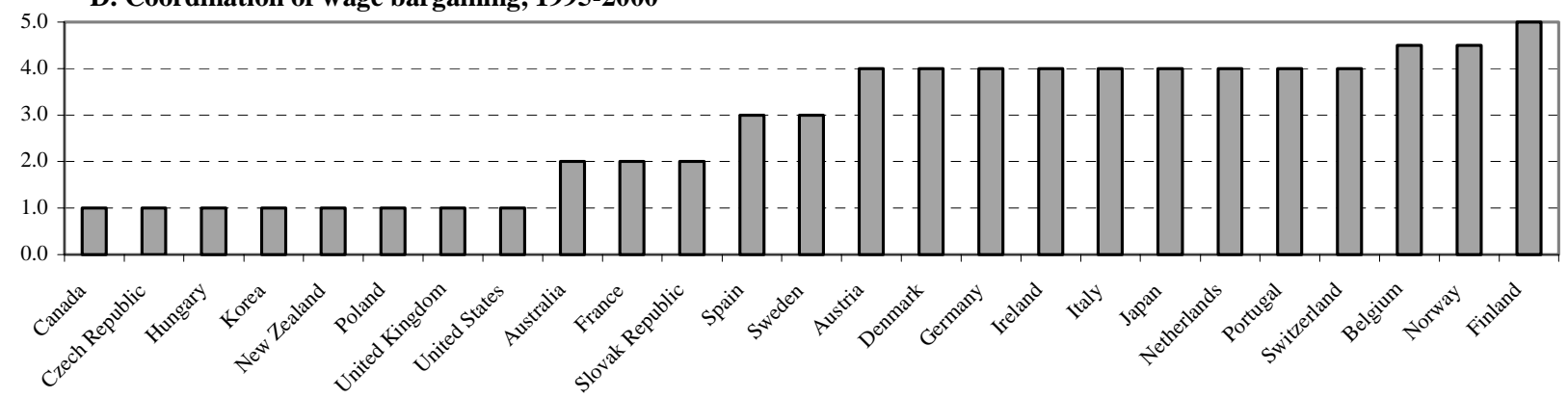

1. Or latest year available.

2. A higher index value indicates more centralised wage setting, index 1-5.

3. A higher index value indicates more co-ordinated wage setting, index 1-5.

Source: OECD Employment Outlook 2004, Chapter 3. 
40. Countries' bargaining structures have been relatively stable over the past decade (Brandt et al., 2005). Australia and New Zealand moved towards more decentralisation and less wage-setting coordination in the early 1990s, while Belgium and Denmark introduced more wage-setting co-ordination in the second half of the 1990s (Denmark introduced more decentralised bargaining at the same time). Both the union density rate and the coverage rate of collective agreements continued to decline in the 1990s in most OECD countries, but the former more than the latter (OECD, 2004c). The discrepancy between the union density rate and the coverage rate has thus increased. Some European countries have also adopted opt-out clauses or other provisions allowing elements of firm bargaining within a more centralised framework. However, despite the increased flexibility that opt-out clauses provide at the firm level, country experiences suggest that, in practice, they are rarely used.

41. The level of statutory minimum wages relative to the median wage level varies significantly across the countries that have legal wage floors (Figure 3.7). In general, there has been no movement in reducing minimum wages. The United Kingdom and Ireland introduced statutory minimum wages in 19992000 as part of other labour market reforms of these countries, notably the increased use of "make-workpay" policies. However, a few countries have sought to lower labour costs by cutting payroll taxes on low earnings or by introducing employment subsidies. Broad programmes providing subsidies to all those in low-paid work are used in relatively few countries (mainly Belgium, France and the Netherlands). More targeted programmes aimed at disadvantaged groups are found throughout the OECD area (OECD, 2003), and they account for a significant share of overall spending on active labour market policies in several countries (Figure 3.8).

Figure 3.7. Ratio of minimum wage to full-time median earnings $2003^{1}$

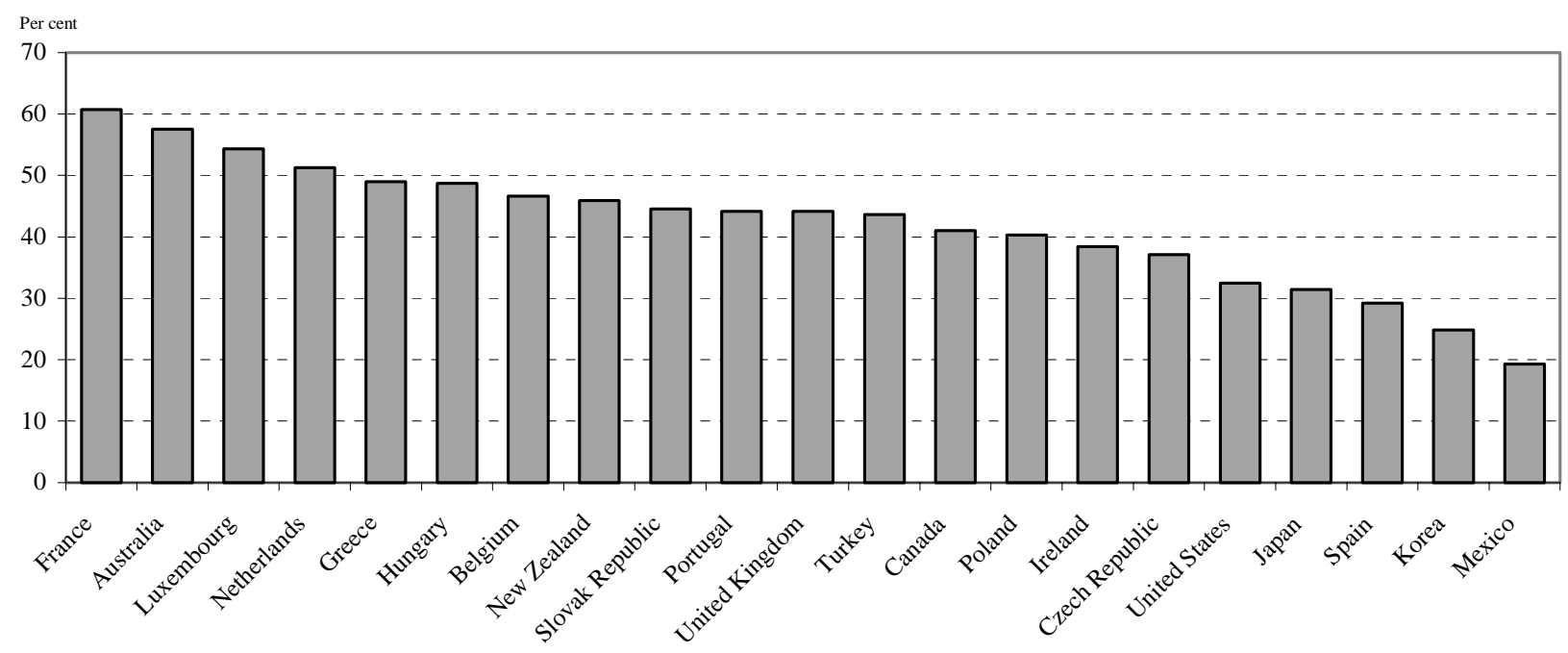

1. 2002 for France, Greece, Hungary and Portugal. Source: OECD Labour Market Statistic Indicators. 
Figure 3.8. Targeted employment subsidies for disadvantaged groups

As a per cent of GDP, 2001

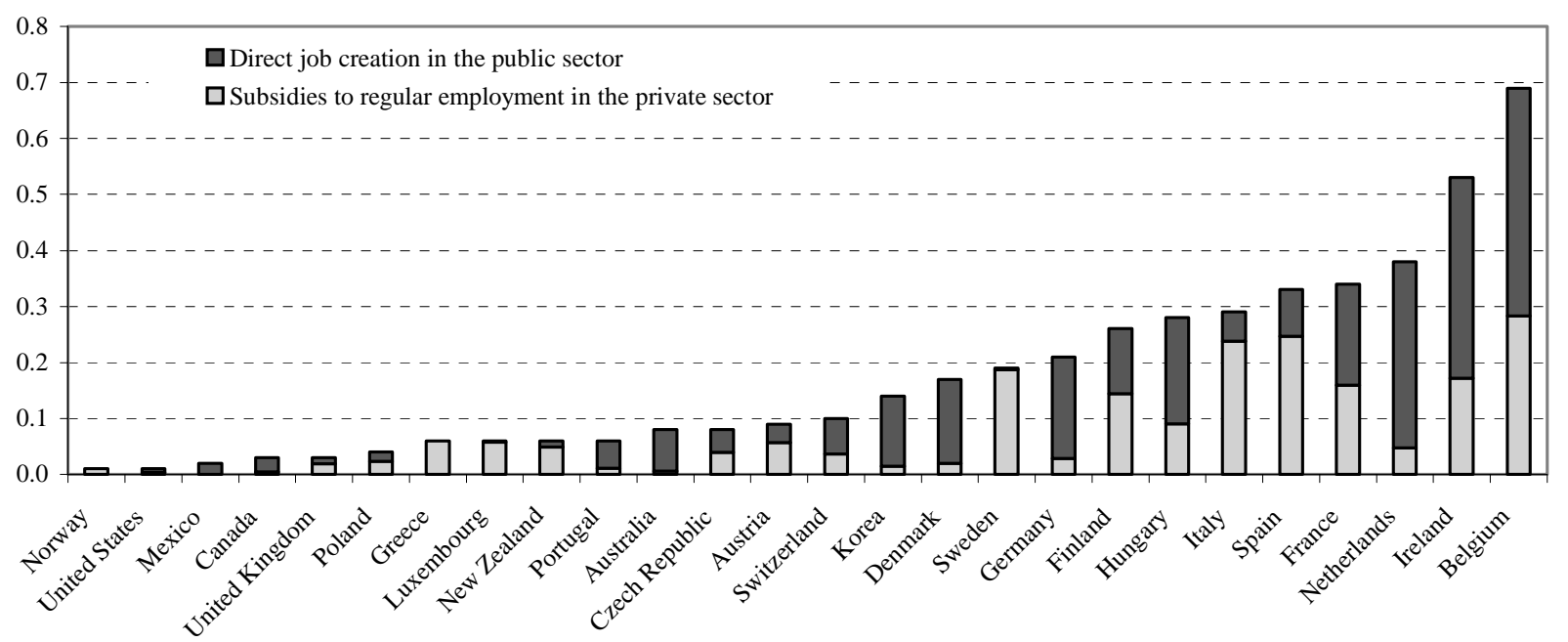

Source: OECD Employment Outlook 2003, Chapter 3.

\section{Recommendations for further action}

42. Several OECD countries have recently been advised to enhance wage setting flexibility so as to better align wages with evolving labour market conditions (including Austria, Belgium, Germany, Italy, Japan, Korea and Spain). In particular, countries have been advised to relax existing practices of administrative extensions of collective wage agreements (including the Czech Republic, Finland, Germany, Italy, the Slovak Republic and Spain) and to reassess the level of minimum wages (including Australia, France and New Zealand).

\subsection{Raising skill levels to create a more flexible workforce}

\section{The impact of education and training on structural adjustments}

43. Education and training systems that provide workers with adequate and adaptable skills could facilitate structural adjustments in several ways. New and expanding activities often demand specialised skills, and skill shortages are frequently reported as an important obstacle to growth. Also, in the global arena, availability of labour with the requisite skills is a key factor affecting the localisation of international affiliates. The extent that countries manage to take full advantage of new possibilities to increase employment and welfare may thus depend on the responsiveness of education and training systems to evolving labour demand, as well as overall attainment rates.

44. Education and training are also positively associated with several aspects of labour mobility. Available micro evidence shows, for instance, that high-skilled workers have much higher job-to-job transition rates than low-skilled ones, and are more mobile across occupations, industries and regions (OECD, 2004d). Data for the United States suggest that there at least, highly-skilled workers are less frequently displaced, and even when they lose their job, they have a relatively high probability of reemployment (Figure 3.9). 
Figure 3.9. Job loss rates and re-employment probabilities: United States

A. Job loss rates ${ }^{1}$

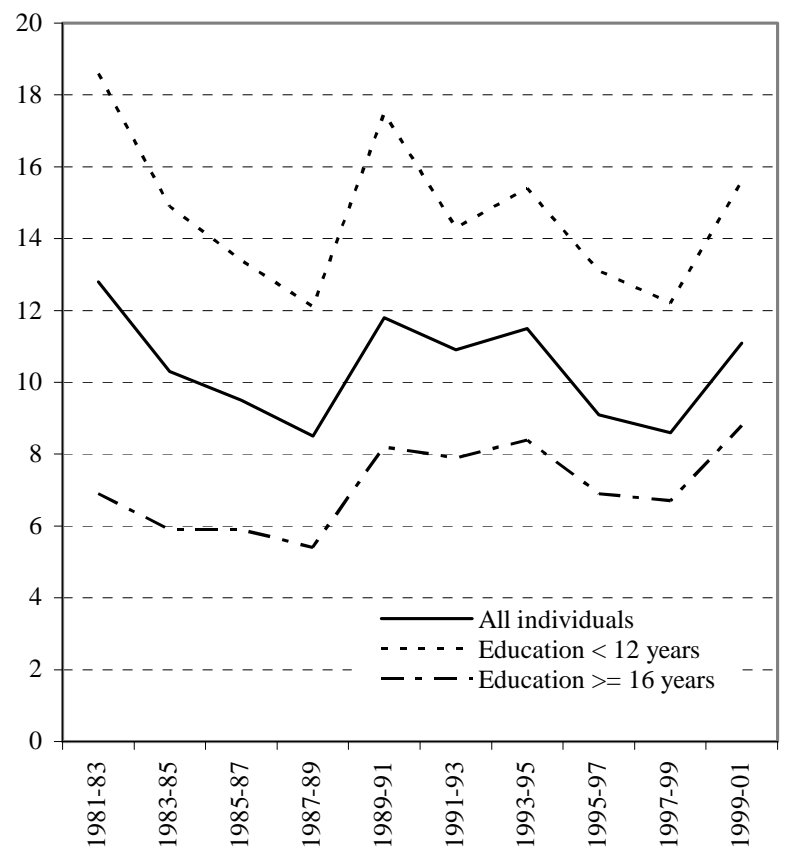

B. Post-displacement employment rates $^{2}$

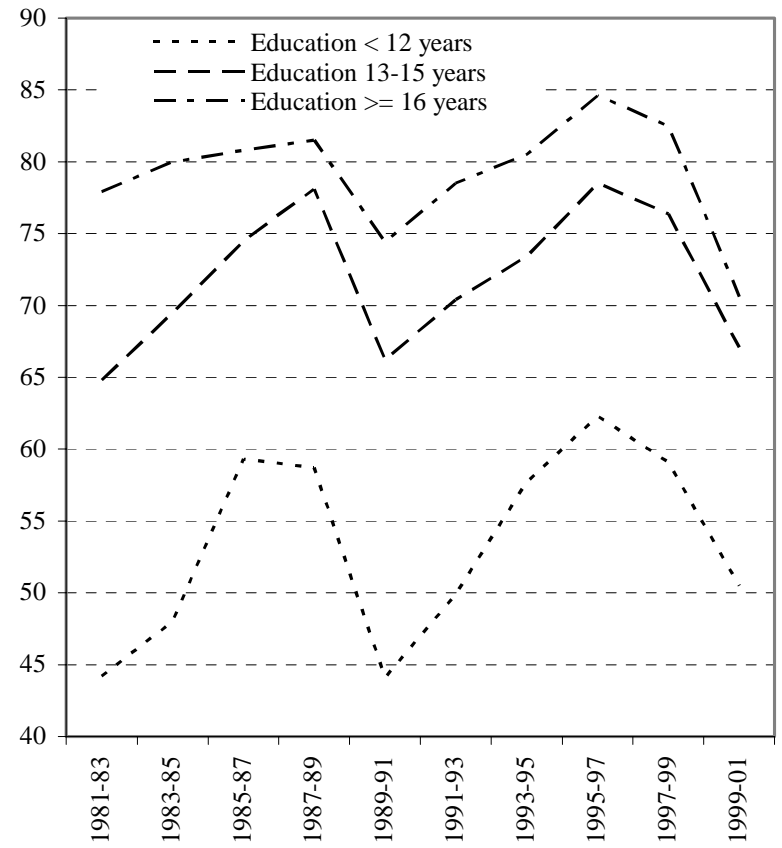

1. Three-year rates of job loss, which are computed as the number of workers reporting having lost a job in the three calendar years prior to the survey date divided by employment plus not-employed job losers at the survey date.

2. Fraction of job losers employed at survey date.

Source: The US Displaced Worker Surveys. See Farber (2003).

45. Like initial education, in-work vocational training seems to be positively associated with several aspects of labour mobility. Trained workers tend to have higher voluntary job mobility, lower involuntary separation rates and higher re-employment probabilities following job losses than non-trained employees (Figure 3.10). There are, however, some exceptions to this pattern. Low-skilled workers that have recently received training have actually lower voluntary separation rates than other workers, possibly reflecting that they to a larger extent accumulate job-specific competences. Similarly, high-skilled workers are reported to have higher involuntary separation rates after receiving in-work training, possibly reflecting adverse selection. In addition to positive effects on labour mobility, in-work training has been found to lower the risk of substantial wage losses for displaced workers (OECD, 2004d).

46. The large positive effects of education and training on different aspects of labour mobility documented in various micro studies may, however, significantly overstate the overall effect of expanding education and training levels (e.g. Vignoles et al., 2004). This is because highly-skilled and trained workers to some extent compete with other workers in the labour market. Better employment possibilities for highly-skilled and trained workers, thus, may come at the expense of less educated and un-trained ones. A selection effect may also be at play, where the workers most likely to benefit from education and training already receive it. Furthermore, high-skilled workers are disproportionately employed in services, which traditionally have had lower displacement rates than the goods-producing sector (Farber, 2003). As more service jobs are becoming exposed to competition, this difference is likely to shrink. In fact, the impact of education on displacement and re-employment probabilities seems to have been somewhat reduced over the past two decades in the United States (see Figure 3.9). 
Figure 3.10. The impact of training on voluntary job mobility, involuntary separation and probabilities of re-employment

\section{Percentage points}

\section{Difference in voluntary job mobility rates $^{1}$}

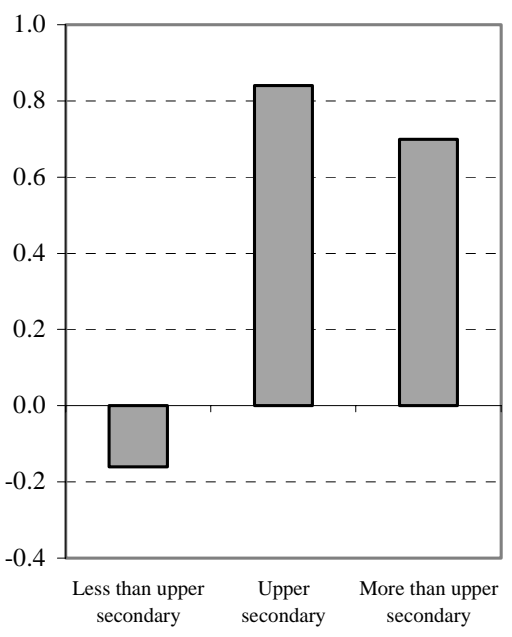

Difference in involuntary separation rates $^{2}$

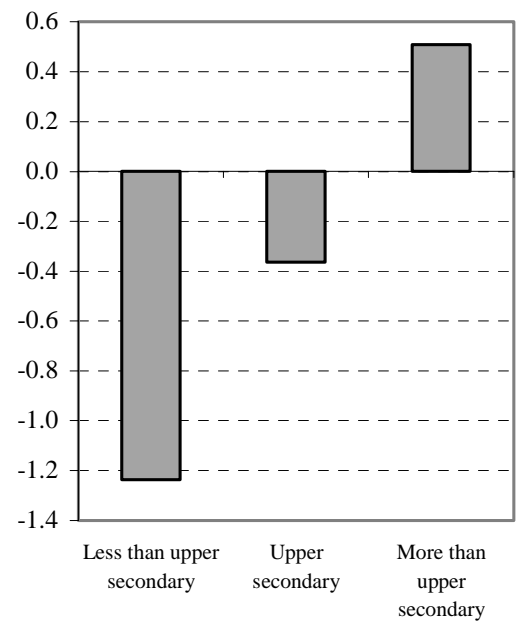

Difference in the probability of reemployment ${ }^{3}$

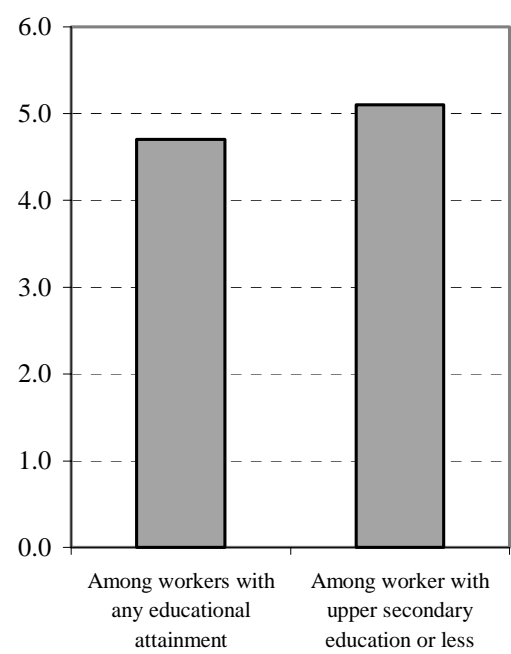

\footnotetext{
1. Percentage-point difference in annualised rates of voluntary job changes between trained and non-trained employees. Weighted average of the following countries: Austria, Belgium, Denmark, Finland, France, Greece, Ireland, Italy, the Netherlands, Portugal, Spain and the United Kingdom.

2. Percentage-point difference in annualised rates of involuntary separations between trained and non-trained employees. Weighted average of the following countries: Austria, Belgium, Denmark, Finland, France, Germany, Greece, Ireland, Italy, the Netherlands, Portugal, Spain and the United Kingdom.

3. Changes in the probability of reemployment as a result of training, percentage points. Source : Employment Outlook 2004, Chapter 4.
}

47. For displaced and unemployed workers, effective training systems could be of particular importance in dealing with structural change, by strengthening productivity and thus improving employability and employment incentives. ${ }^{16}$ However, available evidence on the impact of governmentfunded training programmes on re-employment probabilities for the unemployed is mixed (Martin and Grubb, 2001). In general, large-scale programmes relying on classroom training do not improve reemployment probabilities of participants, while targeted on-the-job training programmes in the private sector do. Again, the overall impact could be overstated, as gains enjoyed by those receiving governmentfunded training might be offset by losses experienced by others not receiving such training.

\section{Education and training levels in OECD countries}

48. The level of initial education differs widely among OECD countries (Figure 3.11, Panels A and B). The percentage of young people with at least upper-secondary education varies, for example, from around 30\% in Mexico and Turkey to well above 90\% in Korea, Norway and the Slovak Republic. Country differences are even more pronounced for workers between 45 and 54 years of age. For instance, in this age group, Greece, Italy and Spain have less than half the share of workers with at least upper-secondary education than the United States.

16. Countries' use of, and experiences with, ALMPs in dealing with displaced workers and structural change is discussed in more detail in Swaim and Tejada (2005). 
Figure 3.11. Indicators of education and in-work training

A. Percentage of 25 to 34 years old that have attained a certain level of education, $2003^{1}$

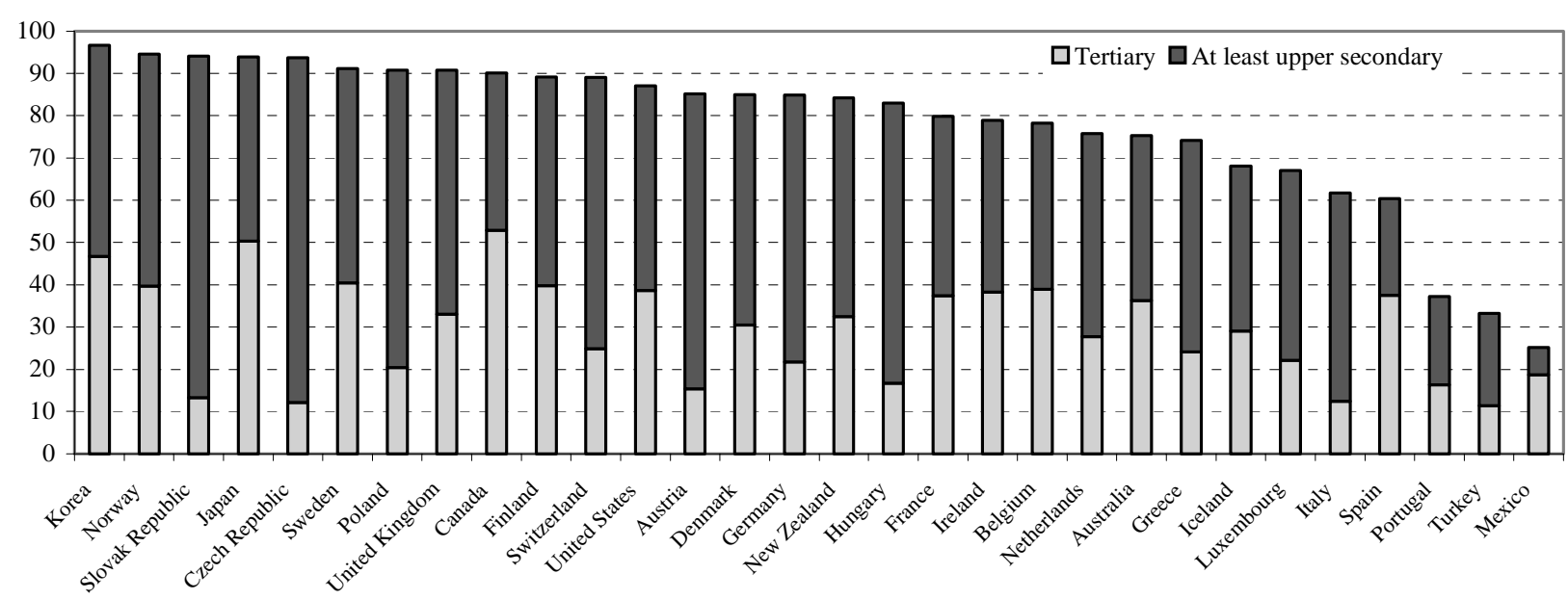

B. Percentage of 45 to 54 years old that have attained a certain level of education, $2003^{1}$
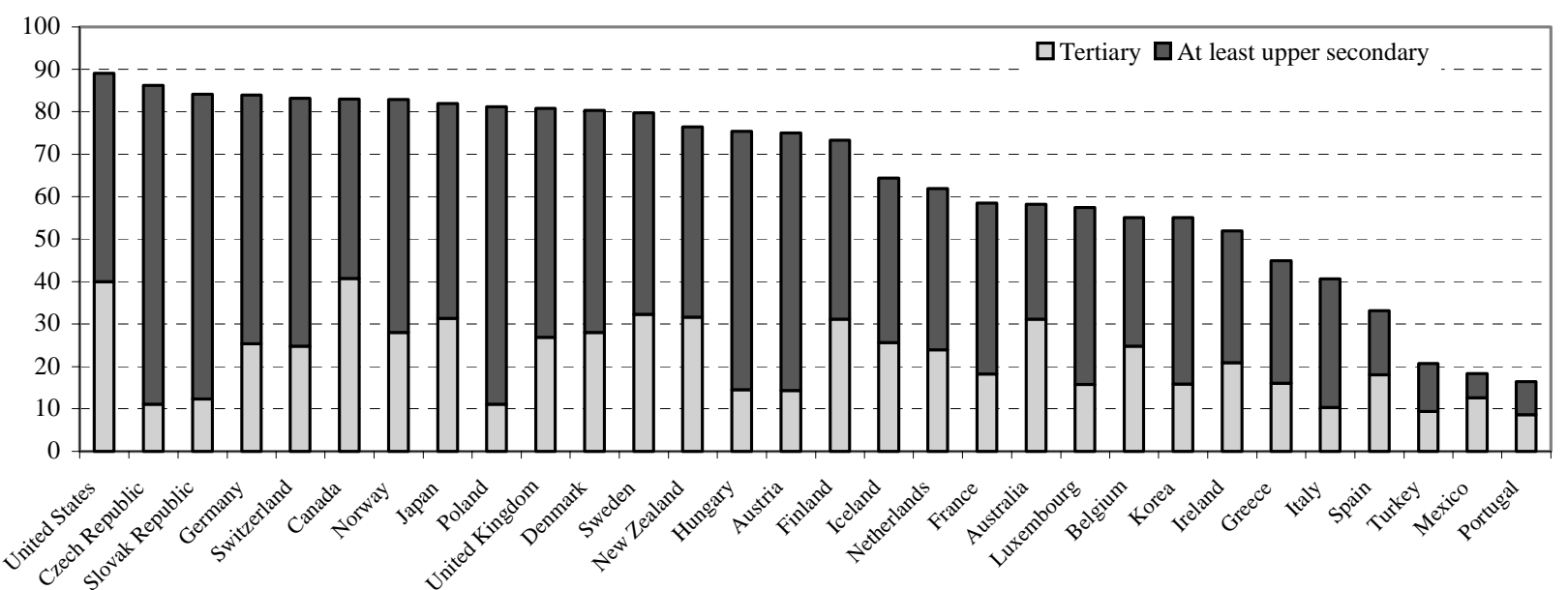

\section{Employer-sponsored education and training, mid 1990s ${ }^{2}$}

Per cent of total employment

Hours per employed person

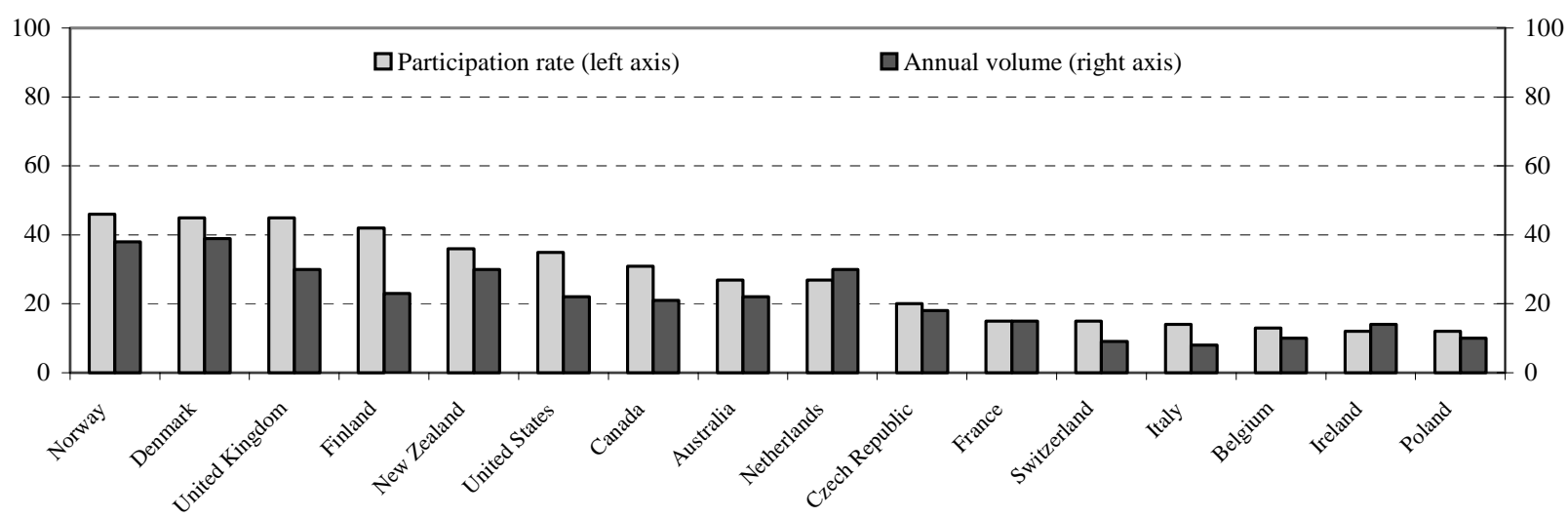

1. 2002 for Denmark, Greece, Iceland, Italy, Japan, Luxembourg, Netherlands, Norway and Switzerland.

2. Data refer to job-related education and training that employers provided (or partially paid) to their workers (26-65 years).

Source: OECD Education Database and OECD Employment Outlook 2003, Chapter 5. 
49. The extent of employer-sponsored education and training shows a similarly wide variation across countries (Figure 3.11, Panel C). It is positively associated with the level of initial formal education, with some countries performing relatively poorly on both counts (including Belgium, Italy and Ireland). The access to in-work training differs significantly across worker groups, even in countries with relatively high overall levels (OECD, 2004d). Highly-skilled workers typically receive much more training than lesser educated workers. Older workers, immigrants, part-timers and temporary workers also tend to receive relatively little in-work training, probably to some extent reflecting a lower rate of return on investments in human capital.

50. For displaced and unemployed workers, the access to training and other active labour market policies (ALMPs) varies widely across OECD countries. Public spending on ALMPs, including training for the unemployed, is particularly high in Denmark, the Netherlands and Sweden, also when compared with the level of unemployment (Figure 3.12).

Figure 3.12. Spending on active labour market policies and training

As a percentage of GDP, $2002^{1}$

\section{A. Total public spending on active labour market measures (ALMPs)}

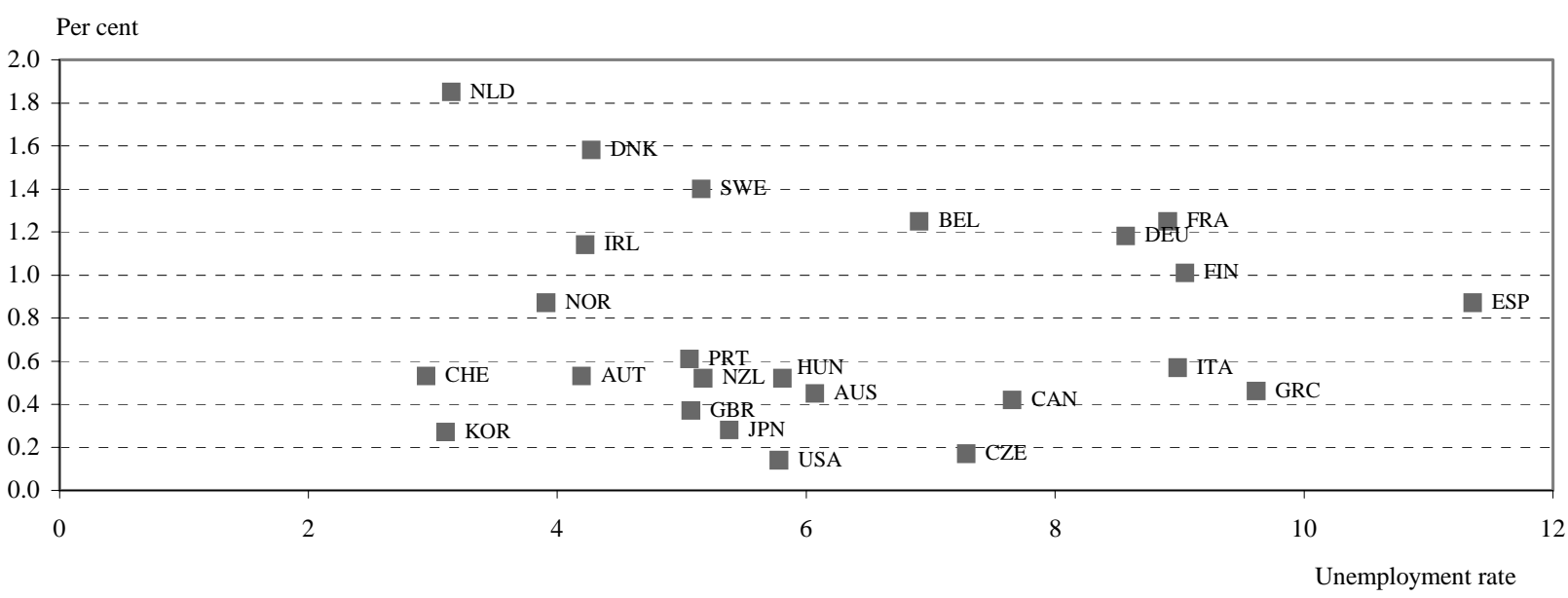

B. Public spending on training for unemployed adults and those at risk

Per cent

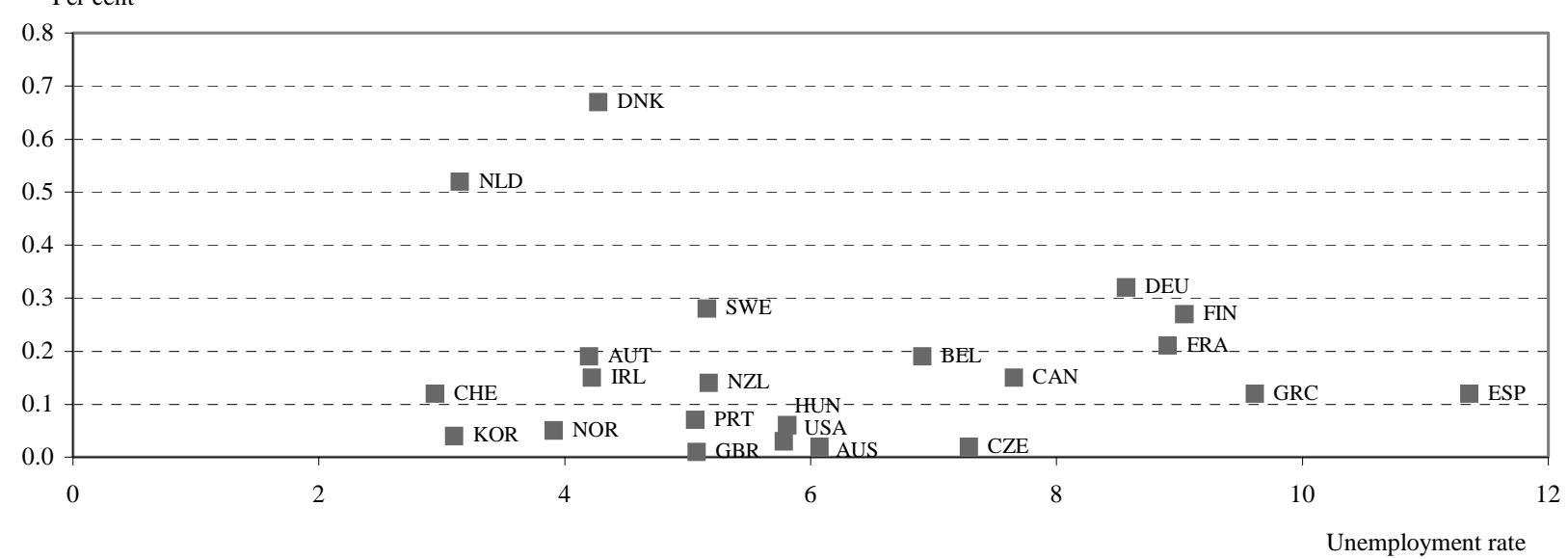

1. Or latest year available.

Source: OECD Employment Outlook 2004 and OECD Labour Force Statistics. 


\section{Recommendations given in recent OECD peer reviews}

51. OECD peer reviews have advised countries to improve education and training systems by:

- Introducing policies that help to ensure that skills meet evolving needs of the labour market (including Australia, Belgium, Canada, Denmark, Germany, Greece, Italy, Japan, Luxembourg, New Zealand, Norway, Portugal, the Slovak Republic, Spain and the United States). More specifically, several countries have been advised to increase enrolment rates in upper-secondary education (including Australia, Canada, Iceland, Italy, Mexico, Portugal and the United Kingdom), or tertiary education (Austria, Germany, Italy, Korea, Poland and the Slovak Republic).

- Providing more in-work training to broad worker groups by cautiously widening public support for adult learning (including Australia, Finland, Greece, Italy, Japan, Korea, Luxembourg, Mexico, Portugal, the Slovak Republic and Switzerland).

- Enhancing the effectiveness and, in some cases, stepping-up the use of ALMPs so as to facilitate the re-integration of displaced workers (including Austria, Belgium, Canada, the Czech Republic, Denmark, Finland, France, Germany, Greece, Japan, New Zealand, Norway, Poland and Portugal).

\subsection{Reducing obstacles to mobility in the housing market}

\section{Housing market policies and regional labour mobility}

52. High costs on property transactions and rigidities in the rented housing sector can seriously impede labour mobility and, thus, the capacity of countries to adjust to structural changes that require regional adjustments. For owner-occupiers, the incentive for regional mobility could be seriously distorted by high transaction costs and tax privileges that are only available after lengthy residence periods. Based on micro data from the Netherlands, van Ommeren and Leuvensteijn (2003) found, for instance, that a one percentage point increase in transaction costs decreased ownership-to-ownership residential mobility rates by as much as $8 \%$.Transaction costs on property are reported to be quite high in several OECD countries, in particular in some European countries. The tax on property transactions is, for example, reported at 11 to $13 \%$ of house prices in Greece and 10 to $12.5 \%$ in Belgium (ECB, 2003). Both these countries are characterised by relatively low regional labour mobility (see Section 2). In comparison, the tax on property transactions is 1 to $4 \%$ in the United Kingdom and in the range of 1 to $3 \%$ in the Scandinavian countries. ${ }^{17}$

53. For tenants, changing accommodation is usually associated with much lower transaction costs than for owner-occupiers. The mobility of tenants may, however, be hampered by other market inefficiencies. For instance, long waiting lists for locally-provided social housing or rent controls for certain accommodations create a segmented market in some countries. Tenants on such contracts may have

17. The expansion of home ownership has been seen as a key impediment to regional mobility in several econometric studies, mainly based on European data (e.g. Oswald, 1999; Barceló, 2003; Huber, 2004). The finding that home owners are less mobile across regions than tenants may, however, reflect unobserved heterogeneity as people tend to buy a house when they think they have settled down. It may also reflect significantly higher adjustment costs, and not home ownership per se. This is, for instance, suggested by empirical evidence from Australia and the United States, where adjustment costs are smaller than in parts of Europe, showing much smaller (if any) effects of home ownership on regional labour mobility (e.g. Flatau et al., 2003). It should also be noted that several studies find relatively high job mobility for owner-occupiers as long as it does not require a change of housing, probably reflecting strong work incentives because of the need to repay mortgage loans (Barceló, 2003). 
few incentives to move even if work possibilities are considerably better in other regions, especially if they have housing costs far below market price. Social housing represents roughly half or more of the rental sector in countries like Austria, Ireland, France, the Netherlands, Sweden and the United Kingdom (Table 3.3)

Table 3.3 Tenure of housing

2002

\begin{tabular}{lcc|c|c}
\hline \multicolumn{4}{c}{ Per cent of the stock of main residence } \\
\hline & Rented & $\begin{array}{c}\text { of which: } \\
\text { Social }\end{array}$ & $\begin{array}{c}\text { Owner } \\
\text { occupied }\end{array}$ & Other \\
\hline Australia & 30 &.. & 70 &.. \\
Austria & 40 &.. & 57 & 3 \\
Belgium & 31 & 7 & 68 & 2 \\
Canada & 37 &.. & 63 &.. \\
Denmark & 45 & 19 & 51 & 4 \\
Finland & 32 & 17 & 64 & 4 \\
France & 38 & 17 & 56 & 6 \\
Germany & 55 &.. & 45 &.. \\
Greece & 26 &.. & 74 &.. \\
Ireland & 16 & 9 & 78 &.. \\
Italy & 22 & 6 & 78 &.. \\
Japan & 40 &.. & 60 & 0 \\
Netherlands & 46 & 35 & 54 &.. \\
New Zealand & 32 &.. & 68 &.. \\
Norway & 23 &.. & 77 & 4 \\
Portugal & 21 &.. & 75 & 8 \\
Spain & 11 &.. & 81 & 15 \\
Sweden & 39 & 21 & 46 &.. \\
United Kingdom & 31 &.. & 69 &.. \\
United States & 32 & .7 & 65 &.. \\
Average of above countries & 32 & & 66 &.. \\
Euro area average & 31 & & & \\
\hline
\end{tabular}

.. Data not available.

1. 1998 for Japan; 1999 for Australia and Italy; 2000 for Canada and Ireland; 2001 for Greece,

Portugal, New Zealand, Norway, and the United States.

Source: Housing Statistics in the European Union (2003); Australian Bureau of Statistics;

Statistics Canada; Statistics Greece; Statistics Bureau of Japan; Statistics New Zealand;

Statistics Norway; U.S. Census Bureau.

54. Inefficiencies in the rental market may also impede the mobility of owner-occupiers by making it more cumbersome, and possibly more costly, to accept temporary work in another region. The incentives for home owners to use the rental market for temporary moves can be further hampered by the tax system, sometimes requiring the owner to live in the house to be eligible for certain tax preferences (including Finland, France, Greece and Italy). Even temporary job moves for home owners may thus require a process of house selling and purchasing, making such moves more cumbersome and costly.

\section{Recommendations given in recent OECD peer reviews}

55. A number of member countries have recently been recommended in OECD peer reviews to improve the functioning of the housing market in order to stimulate regional labour mobility. The functioning of the rental market could be improved by reducing remaining regulations, and this has been seen as being particularly important in Denmark, the Czech Republic, the Slovak Republic and Sweden. 
Measures to reduce the implicit subsidy to home owners could further help to create a more efficient rental market, and has been recommended for several countries (Denmark, Hungary, Iceland, Ireland, the Netherlands, Norway and Spain). Moreover, to ensure a more responsive housing supply, and thus allow a net inflow of labour resources to expanding areas, some countries have been advised to ease residential zoning and planning restrictions (Luxembourg, the Netherlands, Spain, Sweden, Switzerland and the United Kingdom), or to take other measures to improve housing infrastructure (Poland).

\subsection{Easing distortions created by high tax wedges}

\section{The impact of high labour taxes on service markets}

56. Some service activities have characteristics that make them particularly vulnerable to high labour taxes. For example, distributive and personal services rely disproportionately on workers with elastic labour supply, including students, the low-skilled, single parents and second income-earners in families (see Section 2 above). ${ }^{18}$ As a consequence, high labour taxes cannot be shifted completely on to workers in the form of lower after-tax earnings, thus pushing up labour costs. In the case of high payroll taxes, this is sometimes reinforced by other policies effectively creating a wage floor for low-paid workers (see above). Demand for many personal services is also relatively price elastic, reflecting the possibility of do-ityourself work and recourse to non-declared work (e.g. child-care, cleaning and gardening). Together, elastic labour supply and elastic demand create a negative relationship between labour taxes and formal employment in affected services activities (Box 3).

\section{Box 3. Labour taxes and the number of hours required to pay for personal services}

A high tax wedge may discourage demand for market-delivered personal services by increasing the number of hours of work required to pay for them (see table below). In Japan, Korea, Luxembourg and Mexico, the principal earner in a two-income household, earning 100 and $67 \%$ of the average production worker (APW) wage, respectively, with two children has to work slightly less than one hour to pay for one hour of work carried out by a low-paid casual worker. In Belgium, Germany and Italy, the principal earner must work roughly twice as long to be able to pay for the same work. For a skilled tradesman, i.e. for services that are subject to consumption taxes, the household in these countries would have to pay the equivalent of three hours or more of pay for one hour of bought-in services.

The reliance on in-house production of services varies significantly between countries, and this may explain some of the observed differences in market-based service deliveries. Freeman and Schettkat (2002) found, for example, that women in Germany and the United States worked a similar number of hours each day, but that a larger share of this work was in market production in the United States. Cross-country information on the extent of do-ityourself work is sparse, but available studies suggest that such activities are substantial in some countries with high labour taxes (including Denmark and Sweden).

The level of undeclared work is significant in most OECD countries. According to recent estimates, the share of hours worked in the informal economy ranges between 1 and $5 \%$ in Denmark, Germany, the Netherlands, Norway, Sweden and the United Kingdom to more than 15\% in Spain and Italy and more than 30\% in Turkey (OECD, 2004e). Somewhat surprisingly, high tax rates per se do not appear to have a major influence on the extent of undeclared work. In fact, other factors have been found to be of greater importance, in particular the absence of effective taxation of business income, cumbersome regulations in product markets and strict employment protection (Friedman et al., 2000).

1. In Denmark in 2000, for example, the estimated amount of do-it-yourself activities on household repairs and maintenance corresponded to 50000 full-time jobs or around 1.5\% of the working-age population (Brodersen, 2002). A similar figure has been estimated for Sweden (OECD, 2002a).

18. In contrast, labour supply of prime-age males is generally found to be relatively inelastic (Blundell and MaCurdy, 1999). 
Box 3. Labour taxes and the number of hours required to pay for personal services (continued)

Hours of work required to pay for household services, $2003^{1}$

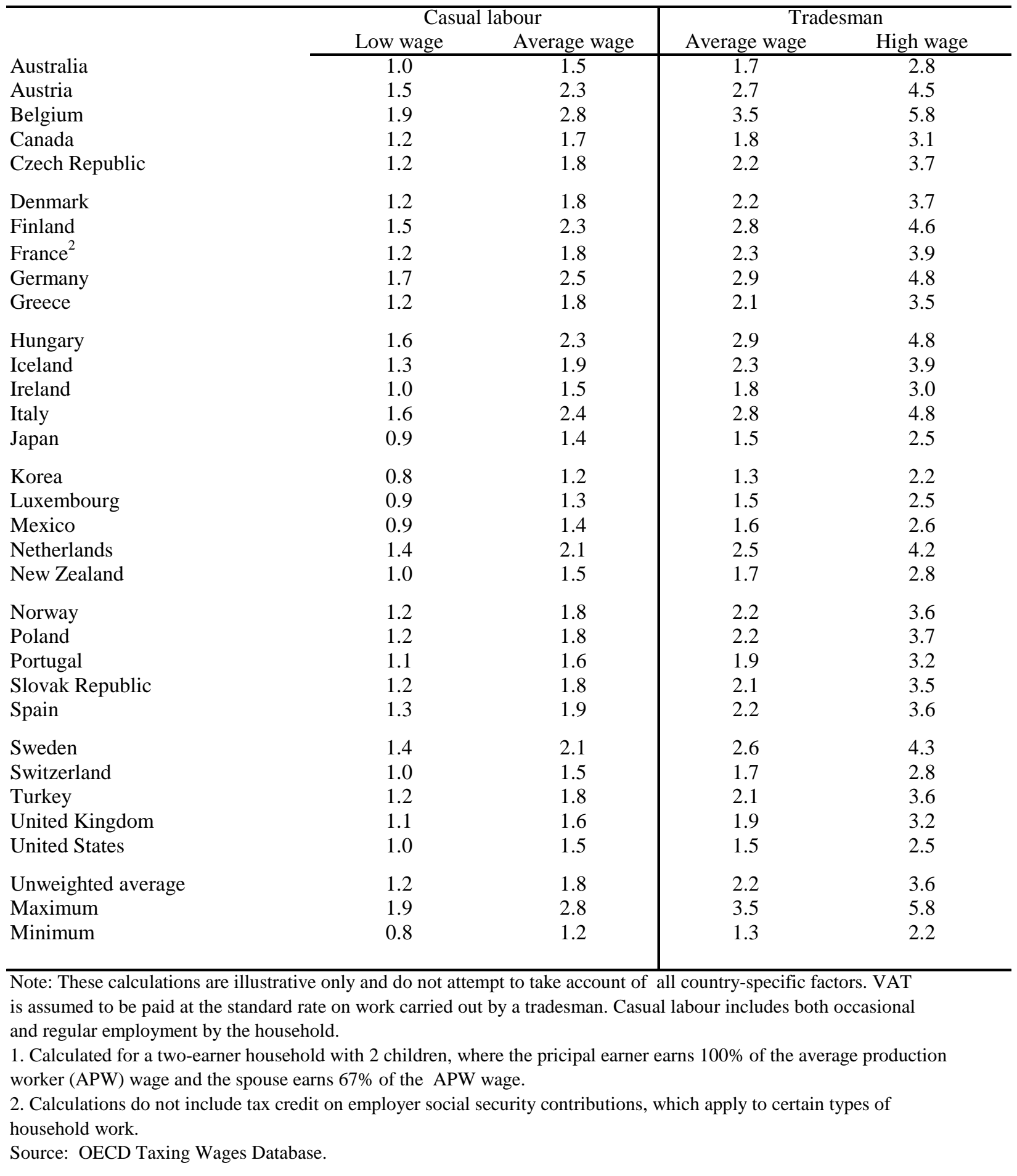


57. Available empirical evidence is mixed on the effect of high labour taxes on service activities (Figure 3.13). In line with the considerations above, a recent OECD study identified a negative effect of labour taxes on employment in personal services (OECD, 2000c). No significant effect was found on overall service employment, however, while the effect on social services was found to be positive. This may reflect that higher taxes are mirrored in higher public spending or subsidies linked to service activities (e.g. education allowances and child-care subsidies). Other studies have, however, identified a significant negative effect of high non-wage labour cost on overall employment levels, especially among low-skilled workers. High relative tax on second-income earners has also been found to significantly reduce the fulltime participation rate of women (Jaumotte, 2003). Both single and married females seem to be relatively willing to substitute between market and in-house produced services (Rupert, 1994). Given the size of services in the overall economy and the reliance on low-skilled workers and women in certain service markets, these findings indicate a negative impact of labour taxes on service activities.

Figure 3.13. Labour taxes and employment in services

$2003^{1}$

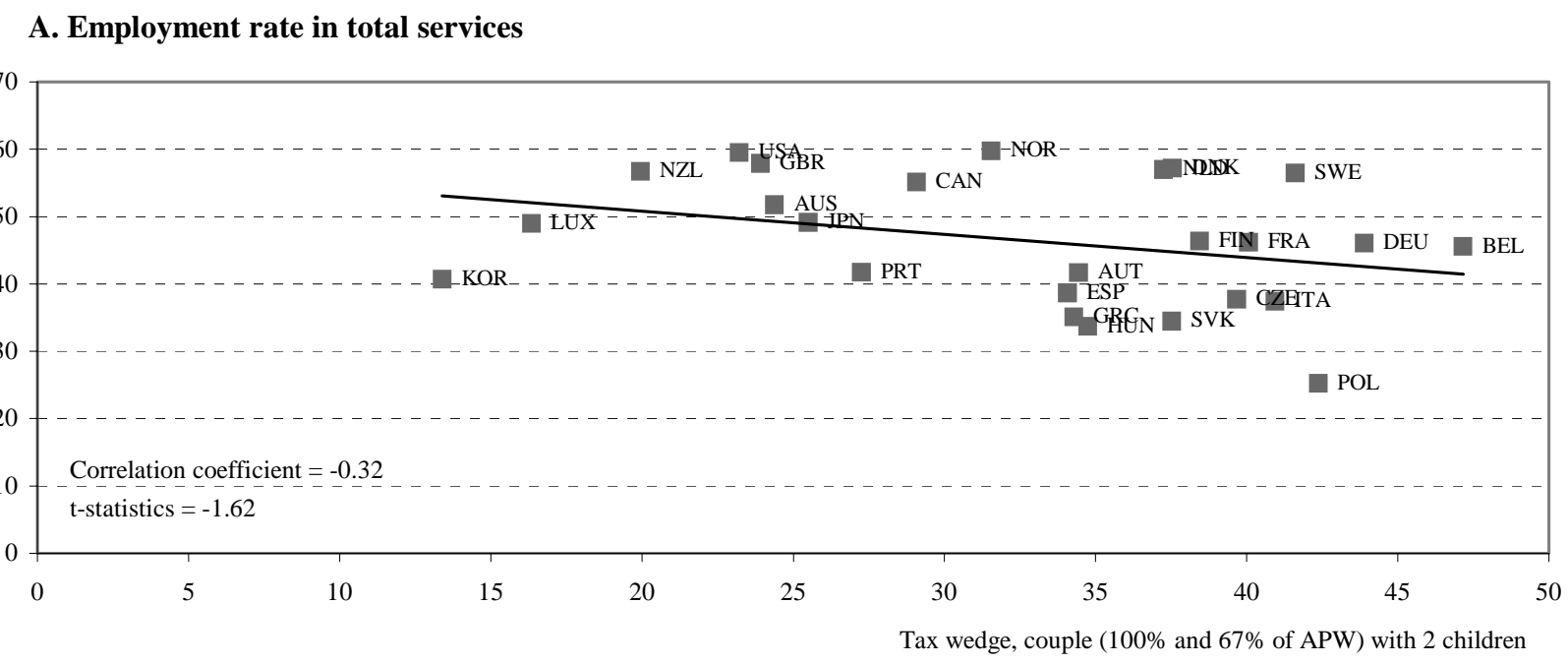

B. Employment rate in personal services

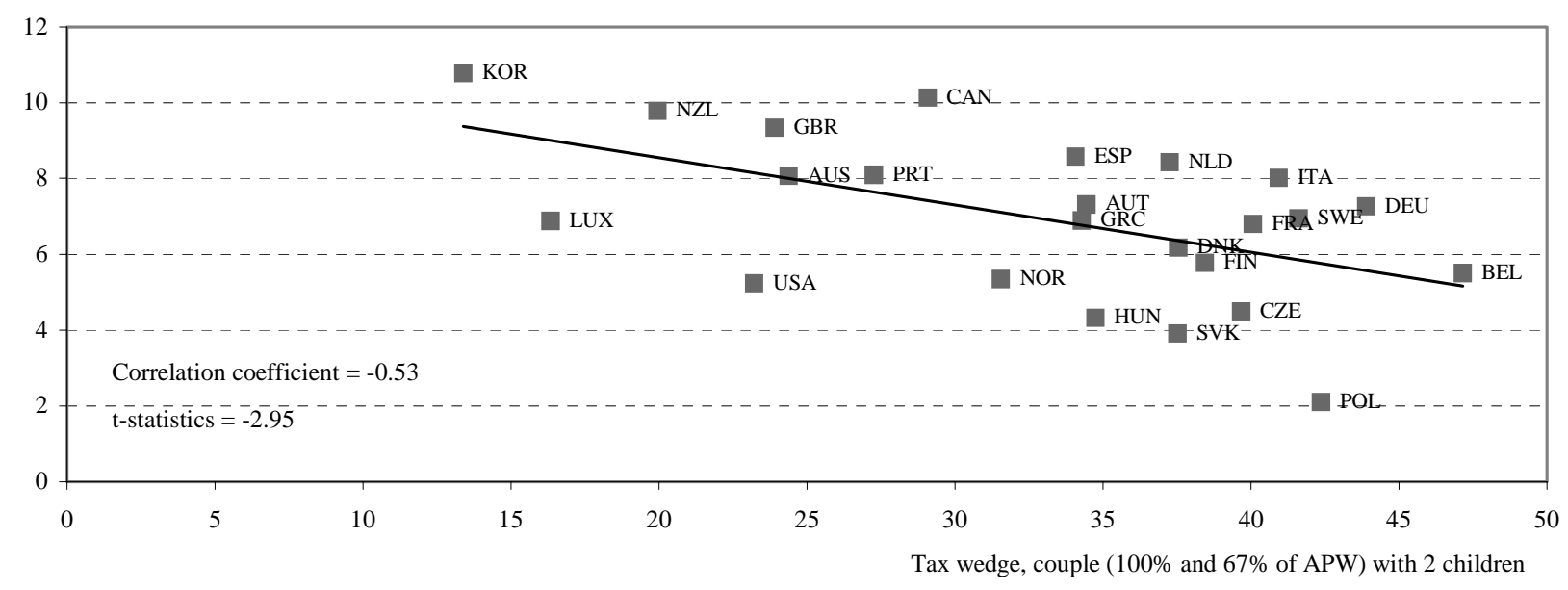

1. Or latest year available. See Appendix 1 for industry classification.

Source: OECD Taxing Wages Database and the OECD STAN Database for Industrial Analysis and Groningen Growth and Development Centre Database. 


\section{The level of labour taxes in OECD countries}

58. The direct tax wedge on labour income varies considerably between countries and the ranking of countries depends to some extent on the measure used (Figure 3.14). For couples earning respectively 100 and $67 \%$ of the earnings of the average production worker (APW), the average tax wedge, including social security contributions, is particularly high in Belgium, France, Germany, Italy, Poland, Sweden and Turkey. Low-income earners are generally taxed at a more favourable rate than those with a higher income, although the total tax wedge is still above 30\% in Greece, Poland, Sweden and Turkey. Moreover, second-income earners in families often face a relatively high tax wedge (Belgium, Iceland, Denmark and Germany), creating an extra disincentive to engage in market-based work. None of the indicators considered here include indirect taxes, which are particularly high in Hungary, Poland and the Nordic countries (up to $25 \%$ ).

\section{Countries' strategies to lessen the impact of high labour taxes}

59. The direct tax wedge on labour has been lowered in several OECD countries since the mid1990s, in particular on low-income earners (OECD, 2004f). For single parents with two children earning $67 \%$ of the average production worker wage, for instance, the total direct tax wedge has been cut in more than two-thirds of OECD countries. In some cases, the cut from 1996 to 2003 amounted to more than ten percentage points (Ireland, Italy and the United Kingdom).

60. By contrast, consumption taxes have been relatively stable in most countries over the past decade, and have, on average, increased slightly in the OECD area (OECD, 2005b). General reductions in the consumption tax rate are costly in terms of foregone revenues, and alleviating adverse effects on certain services could arguably justify differentiated consumption taxes. Several countries already have VAT rate differentiation and exceptions, but lower rates are mainly targeted at basic goods and services (i.e. not necessarily services with elastic labour supply and elastic demand). However, significant weight should be attached to the principle of having a neutral and simple tax system, and this argues against introducing lower rates on selected services.

61. A number of countries have relied on more targeted policies to counteract perceived negative effects of high labour taxes on the employment of low-skilled workers in personal services. Tax credits or subsidies for households employing domestic staff have been introduced in several countries (including Denmark, France, the Netherlands and Germany), while administrative procedures have also been simplified. In France, for example, private households employing labour are entitled, up to a ceiling, to a tax refund equal to $50 \%$ of the total amount of wages and social security contributions, ${ }^{19}$ while routines for tax and social security payment arrangements are simplified. Furthermore, several countries have introduced policies aimed more directly at stimulating female labour supply (Box 4).

\section{Recommendations given in recent OECD peer reviews}

62. A number of countries, mostly European, have recently been advised to strengthen employment incentives by lowering labour taxes in general (including Belgium, Denmark, Finland, France, Germany, Greece, Italy, the Netherlands, Norway, the Slovak Republic, Sweden and Turkey). More specifically, Australia and several European countries have been advised to reduce taxes on low incomes, while the Czech Republic, Germany, Ireland and Luxembourg have been advised to cut taxes on second-income earners. Several European countries have also recently been advised to implement family-friendly policies in a manner more conducive to female labour supply.

19. A similar programme is found in Denmark, although it has recently been substantially tightened to cover only house cleaning and is only eligible for pensioners. 
Figure 3.14. Direct tax wedge on labour

2003

A. Average direct tax wedge on couples earning $100 \%$ and $67 \%$ of average production worker with 2 children ${ }^{1}$

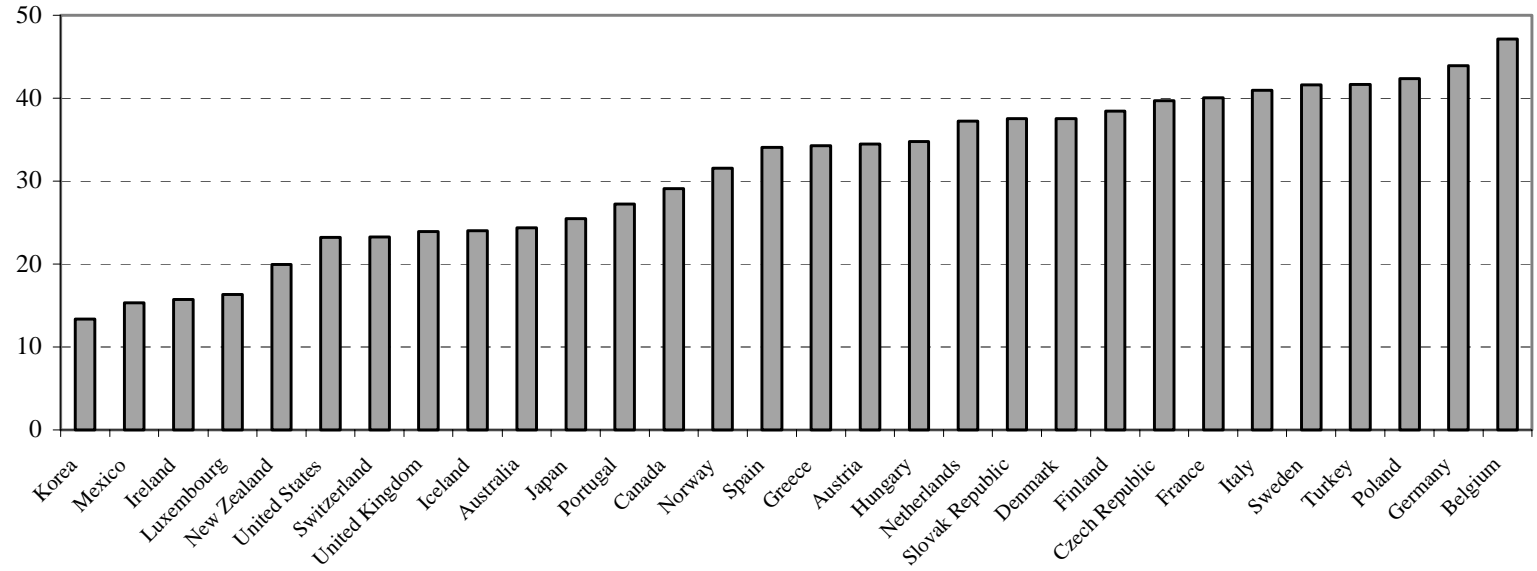

B. Average direct tax wedge on couples earning $40 \%$ of average production worker each with 2 children ${ }^{1}$

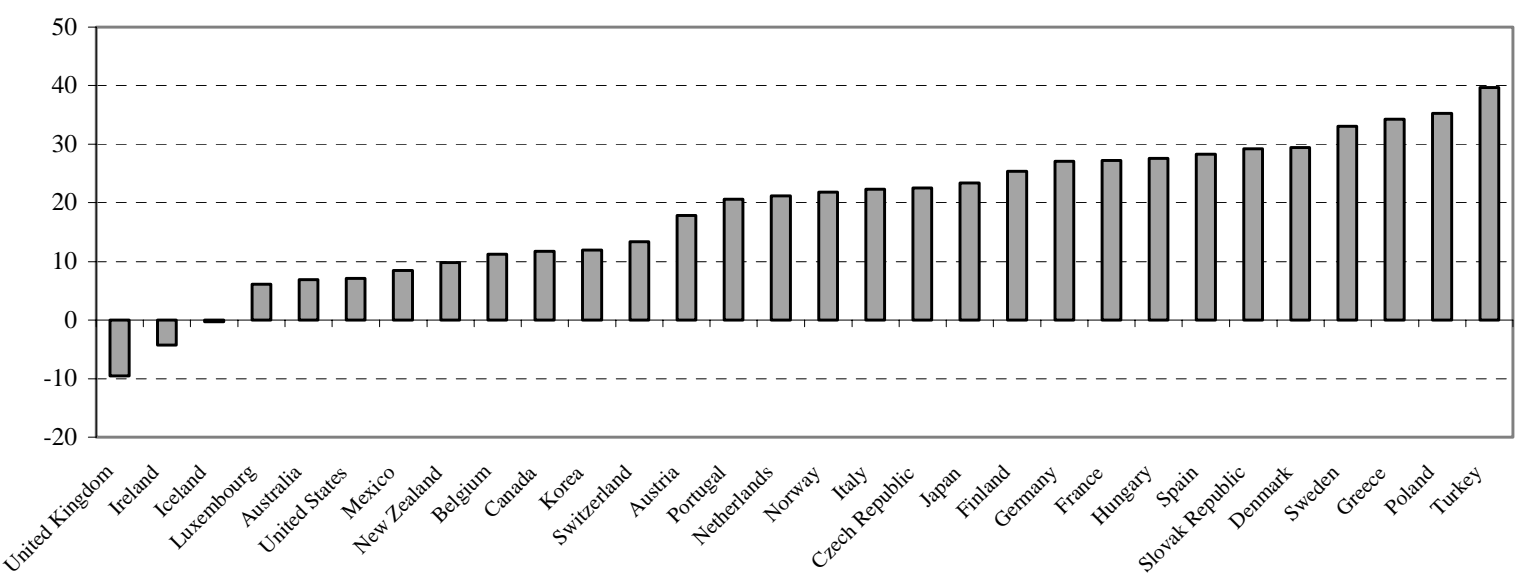

C. Average direct tax wedge on second income earners ${ }^{2}$

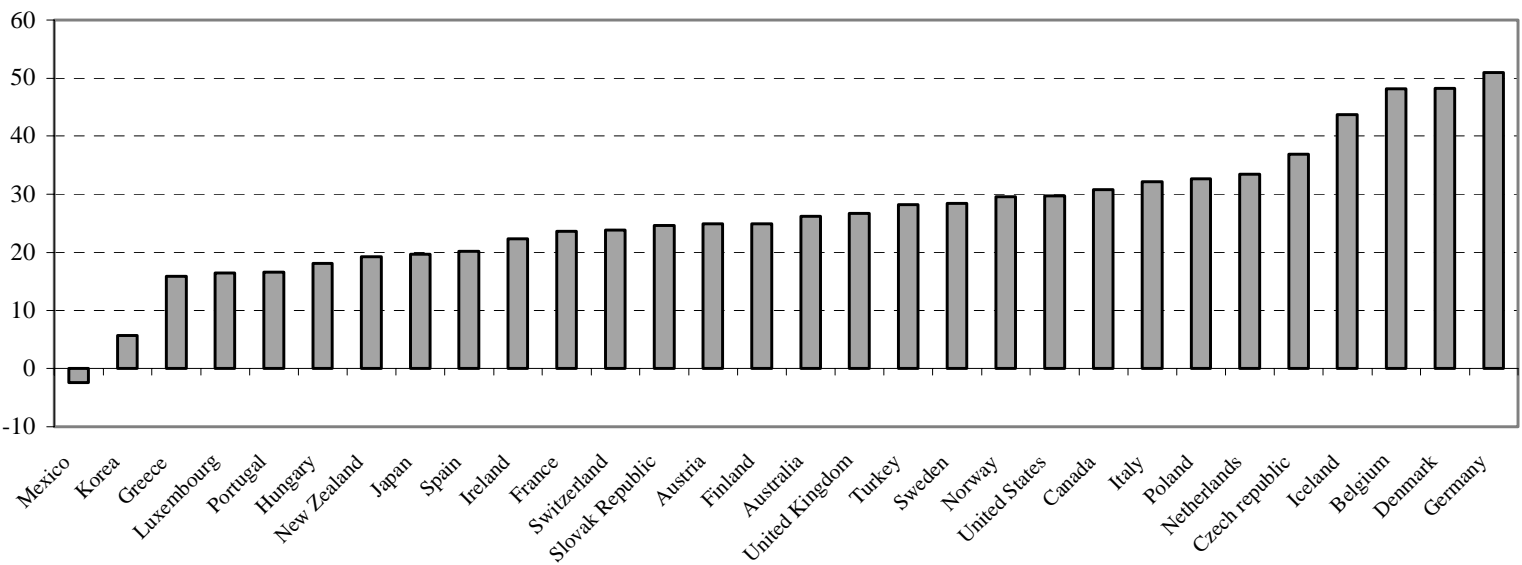

1. The direct tax wedge on labour includes social security contributions, but not indirect taxes, and is less cash benefits. 2. Average tax rate on a second-earner earning $67 \%$ of APW with two children (excluding employer's social security contribution and indirect taxes. The principal income earner is assumed to earn $100 \%$ of APW.

Source: OECD Taxing Wages Database. 


\section{Box 4. Female labour supply and service sector employment}

Policies aimed at stimulating female employment can have important positive effects on developments in services by raising overall labour supply and by shifting some service activities into the formal market (see figure below). Female labour force participation is relatively low in several countries (in particular Greece, Hungary, Italy, Poland and Spain). Low employment levels may, to some extent, reflect cultural factors and different preferences. But, according to available surveys, the percentage of inactive women who would like to work is substantial in many OECD countries, particularly amongst those who do not seek employment because of family responsibilities (Jaumotte, 2003). This indicates a significant potential for further employment growth among women in these countries.

A wide range of policies may help stimulate female labour force participation. Several countries have, for instance, introduced public subsidies for child care, effectively reducing the implicit tax on paid work. Empirical evidence suggests that this policy has succeeded by increasing the labour supply from single parents and second income-earners in couples with children, although the elasticity is not always found to be very high. Other policies, including more flexible working-time arrangements and liberal regulations on opening-hours, may further help stimulate female employment, by providing employment possibilities at times that can be more convenient for some workers.

\section{Female employment rate and employment in services}

Per cent, $2003^{1}$

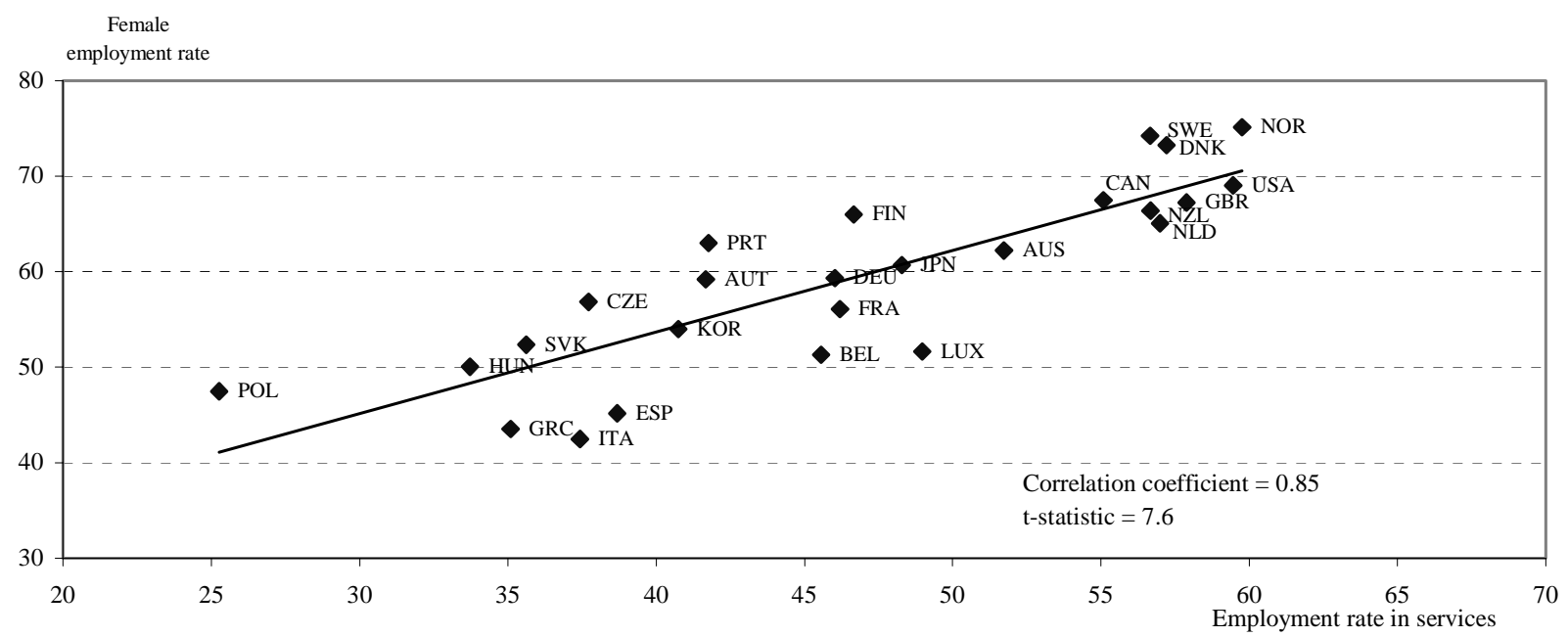

1. Or latest year available.

Source: OECD Labour Force Statistics and OECD STAN Structural Analysis Database. 


\section{Removing barriers to competition and growth in service markets}

63. The capacity of countries to adjust to changing circumstances and to improve the performance of the service sector is influenced by the strength of competition in product markets. This section reviews product market regulations and border barriers that weaken competitive pressures. It also reviews the extent and scope of the use of market mechanisms in the provision of social services, which account for up to half of all service sector employment in some countries.

\subsection{Product market regulations and domestic competition}

\section{The impact of regulations on service-sector performance}

64. A competitive domestic environment plays an important role in promoting an efficient and dynamic service economy. High administrative burdens to business start-ups have, for instance, been found to deter employment expansion in market services by acting as a barrier to the creation of new firms (e.g. Messina, 2004). Industries that usually have relatively high entry rates, including communications and some producer services, seem to be particularly affected by stringent entry regulations (Klapper et al., 2004). Adverse effects of anti-competitive regulations have also been identified in other large service industries. In the retail trade sector, for example, regulatory barriers to the establishment of large-scale retail outlets have been seen to significantly reduce productivity and employment. Similarly, in the transport sector, regulatory hurdles have been seen as holding back investments (Alesina et al., 2003), with potential negative effects on both productivity and employment. ${ }^{20}$

65. The evidence for the adverse effect on services is supported by other research that looks at the impact of stringent product market regulations on overall economic performance. This work suggests that more competition can strengthen firms' incentives to innovate, respond to clients' needs and adopt best practices, while reduced potential for rent creation lowers prices, stimulates activity and increases labour demand. ${ }^{21}$ Although these findings do not directly relate to the service sector, the results are likely to be relevant. Indeed, simple cross-country comparisons indicate that countries with strict overall product market regulations tend to have lower employment in market services than countries with less restrictive regulations (Figure 4.1).

\section{The extent of regulation in key service sectors}

66. Despite most OECD countries having pursued substantial regulatory reforms over the past decade, anti-competitive regulations are still prevalent in many countries and, in particular, in many service industries. This section provides a brief overview of existing regulations that may deter competition and performance in selected domestic service markets: professional services, transport and retail trade. These sectors have been selected on the basis of their size in terms of economic activity (retail trade) or because anti-competitive practices seem to be particularly pronounced (professional services and transport). More comprehensive overviews of regulatory regimes in member countries are provided in individual OECD Country Surveys and in Conway et al. (2005).

20. See Gönenç et al. (2001) for a survey of recent experiences with regulatory reforms.

21. See, for instance, Nicoletti and Scarpetta (2003), Bassanini and Ernst (2002), Bartelsman et al. (2003) and OECD (2002b). A few authors have, however, also pointed out possible adverse effects from stronger product market competition on employment. Amable and Gatti (2004) argue, for example, that higher job turnover may create wage pressures due to the impact on efficiency wages premiums and the wage premium for potentially firing firms. 
Figure 4.1. Product market regulations and employment in market services

$2003^{1,2}$

\section{A. Product market regulations and employment rate in market services}

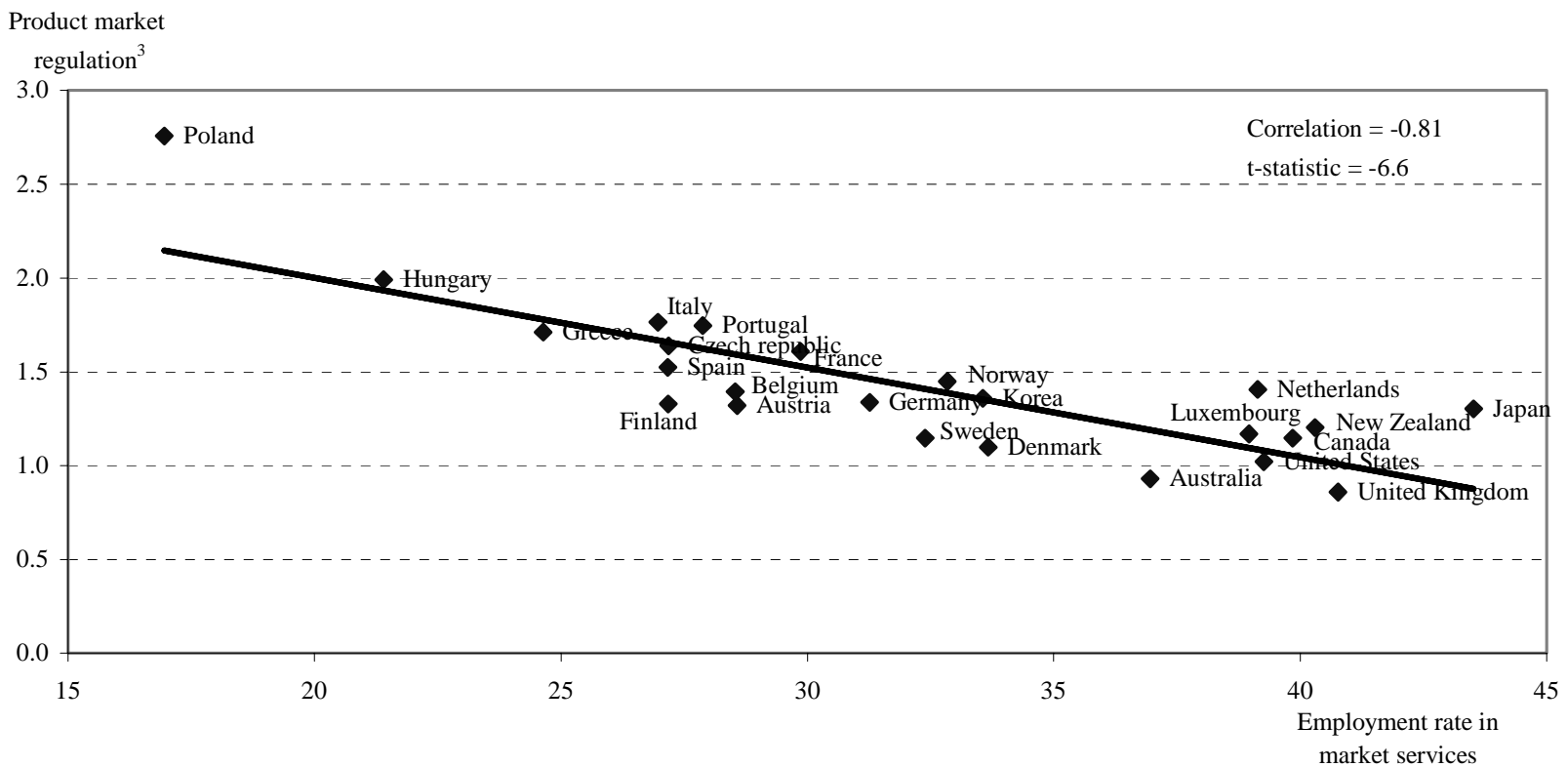

B. Product market regulations and employment share in market services

Product market

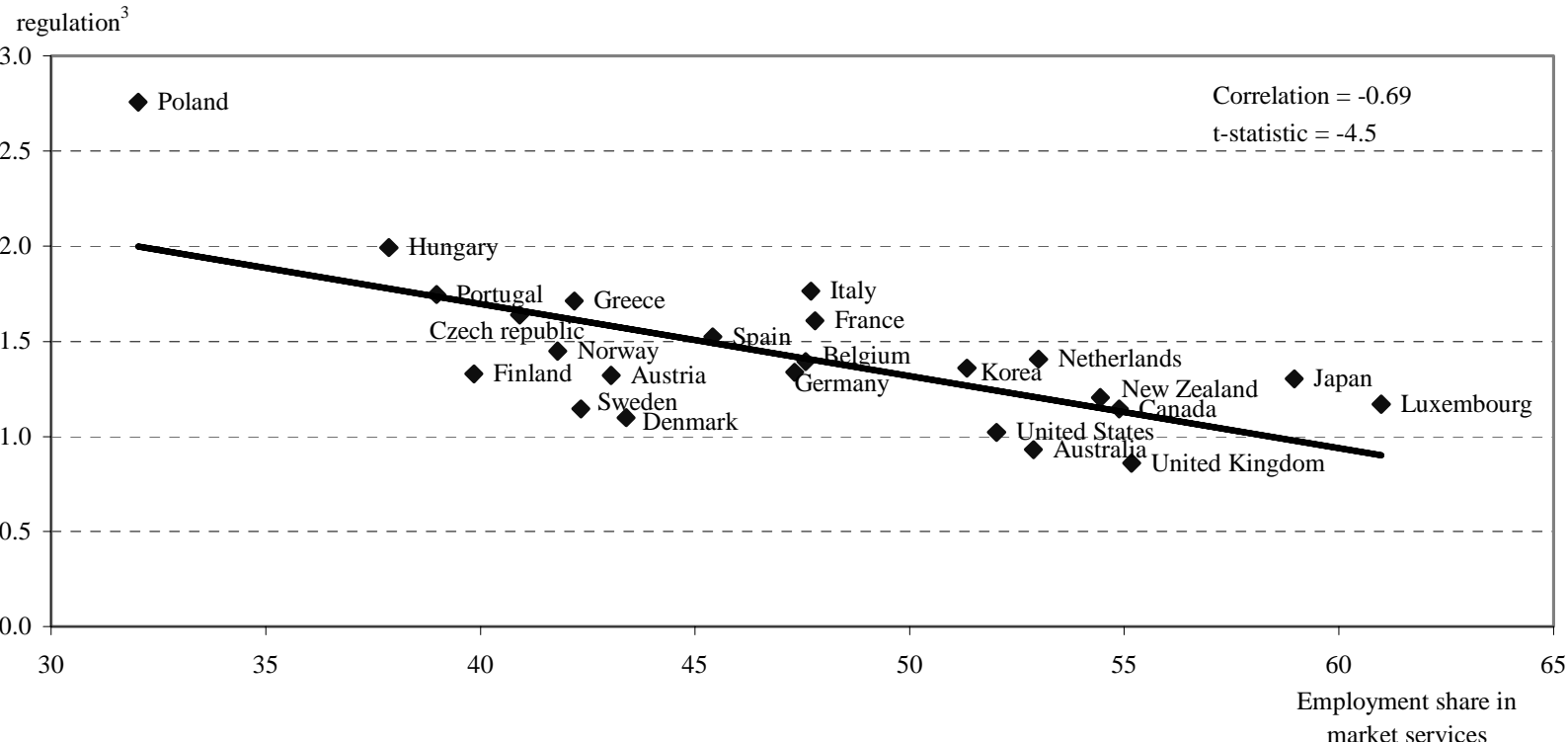

1. Employment in services excluding government employment, health and education.

2. 2003 or latest year available.

3. Index 0-6 scale from least to most restrictive.

Source: OECD Product Market Regulation Database and OECD STAN Structural Analysis Database. 
67. Professional services, including legal work, architectural work and engineering, provide one example of a service sector which is subject to heavy anti-competitive regulations in many OECD countries. Professions are often given exclusive rights to provide certain services, while professional associations are given wide powers to decide on entry requirements, rules of conduct and even recommended or fixed prices. Membership in professional associations is also compulsory in some OECD countries, including Austria, Germany, Japan and Korea. Overall, entry and operational restrictions in professional services are particularly stringent in Germany, Italy, Luxembourg and Turkey (Figure 4.2, Panel A).

68. The transport sector provides another example of a heavily regulated activity. Domestic air and road transport markets are, for instance, sometimes subject to strict entry and licensing requirements and characterised by significant government involvement, while price controls apply in some segments (e.g. road freight in Italy). Taxi services and local and long-distance bus operations are often subject to strict approval requirements, usually involving local government. This may result in inefficient zoning restrictions in local transport markets and seriously complicate the provision of long-distance bus routes. The number of taxis is limited in several cities, implying that people wishing to obtain a taxi license often must purchase it from an existing license holder. ${ }^{22}$ Railway transportation is also generally characterised by strong government involvement and only one or a few service providers, while public subsidies for rail transport and cross-ownership of bus companies sometimes weakens effective competition on inter-city transport. According to OECD indicators (from 1998), regulations of transport services are particularly pronounced in Greece and Italy (Figure 4.2, Panel B). However, significant deregulation has taken place in these industries in recent years.

69. The retail sector is generally characterised by a large number of competitors and few barriers to firm entry. But the development of so-called hypermarkets has been obstructed in many countries by tight regulations on the establishment and expansion of large retail outlets, often with the objective of protecting small shops in town centres. Some countries have introduced a ban on new large shopping centres (e.g. Denmark), or introduced appeal processes that can delay the establishment of hypermarkets for years (e.g. France and Switzerland) ${ }^{23}$ In some countries, the entry of supermarket chains is resisted by local authorities, sometimes influenced by local business interests (e.g. Belgium, Italy and Japan). Barriers to the establishment of large retail outlets have been identified as a main obstacle to productivity growth and employment in retail trade (e.g. Bertrand and Kramarz, 2002; Boylaud and Nicoletti, 2001a). Given the importance of the retail trade sector, both in terms of employment and value-added, the adverse impact on overall economic performance can be significant (Box 5).

70. Regulations on business operations, including shop opening hours and the freedom to set prices, as well as the use of labour resources, pose additional restrictions on retail trade in several OECD countries. In France, for instance, restrictions on price competition have recently been recognised as significantly pushing up prices on some brand-name products compared with neighbouring countries. All in all, anti-competitive product market regulations in retail trade seem to be particularly stringent in Belgium and Greece (Figure 4.2, Panel C). In addition, strict regulations on the use of labour resources may further hamper labour productivity in retail trade. For example, restrictions on the splitting up of the working time for employees into two or more shifts per day might be particularly harmful, as it implies

22. In the United States, for example, the number of taxi licences was unchanged in New York from 1937 to 1996, resulting in high costs and poor availability of taxis and substantial rents to license holders (The Economist, 24 April, 2004). In France, the number of taxi licences in Paris is smaller than in 1926 (Cahuc and Kramarz, 2004). The taxi market has recently been deregulated in many OECD countries, notably in Ireland.

23. In Switzerland, for example, the appeal process can delay the building of a hypermarket by between 10 and 15 years (Giorno et al., 2004). 
significant slack outside peak hours. Such arrangements should be subject to bargaining between employers and employees, so that inconvenient working time arrangements could be compensated by higher wages and not blocked altogether.

\section{Box 5 . The wholesale and retail trade sector and overall economic performance}

The wholesale and retail trade sector has delivered solid productivity growth over the past decade in several OECD countries (see figure below), often surpassing that of the manufacturing sector (Wölfl, 2005). Given the importance of this sector, it significantly affects productivity developments at the national level. In an analysis of productivity growth differentials between the United States and Europe, Van Ark et al. (2003) showed, for example, that more than half of the aggregate growth gap in the late 1990s could be explained by different developments in retail trade and another one-quarter could be explained by different developments in wholesale trade. ${ }^{1}$

\section{Regulation and productivity growth in the wholesale and retail trade sector}

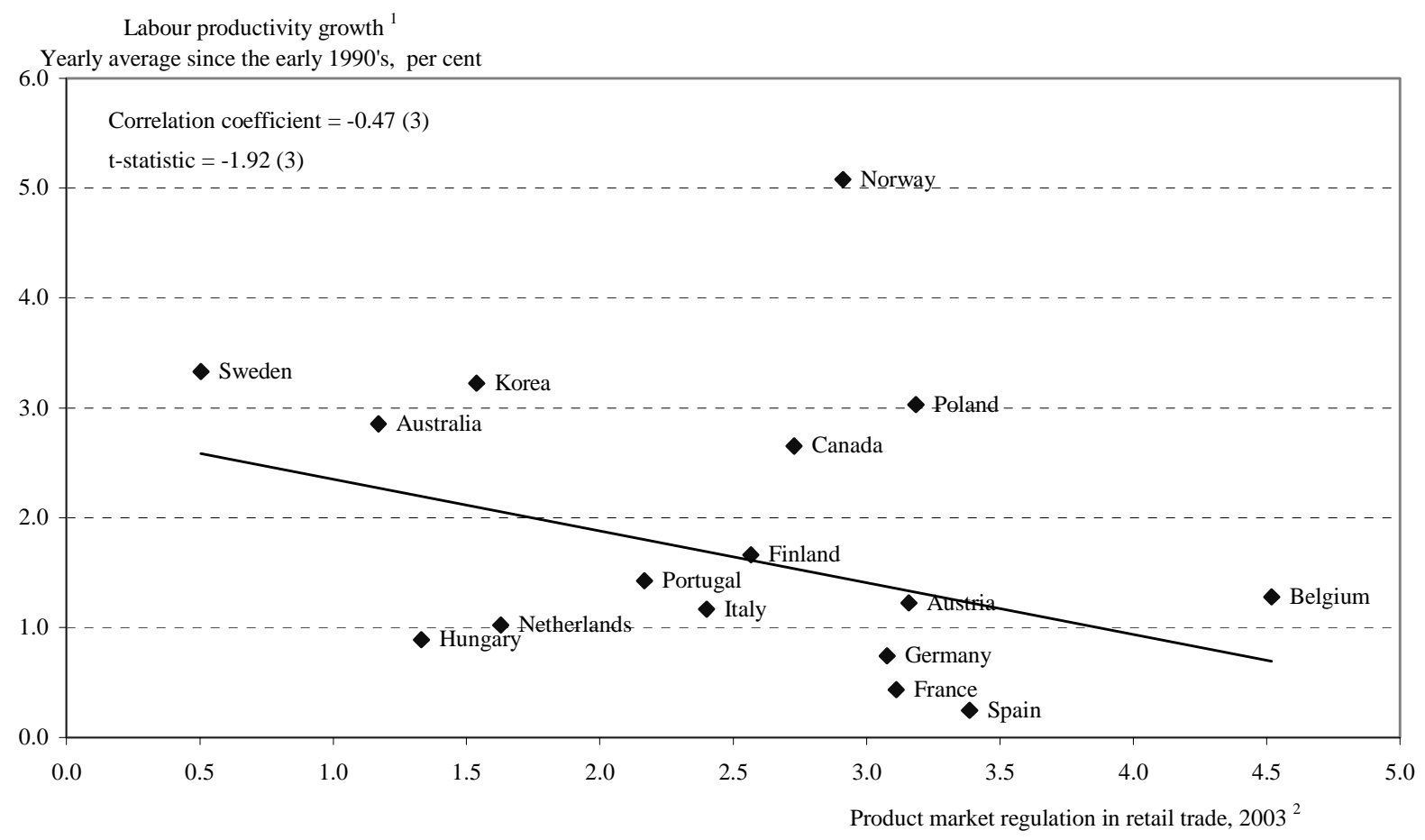

1. The growth rates are not adjusted for the cycle.

2. Preliminary data. Index 0-6 scale from least to most restrictive.

3. Excluding Norway.

Source: The OECD STAN Database for Industrial Analysis and OECD Product Market Regulation Database.

1. See also Gordon (2004) for a recent discussion of factors behind the observed growth differential between Europe and the United States over the past decade. The use of hedonic price indices may artificially inflate productivity in retail trade as the volume of goods sold increases more than the number of items handled. This is, however, not likely to significantly alter the findings above (van Ark et al., 2004). 
Figure 4.2. Regulation in selected service sectors ${ }^{1}$

A. Professional services, $\mathbf{2 0 0 3}^{2}$

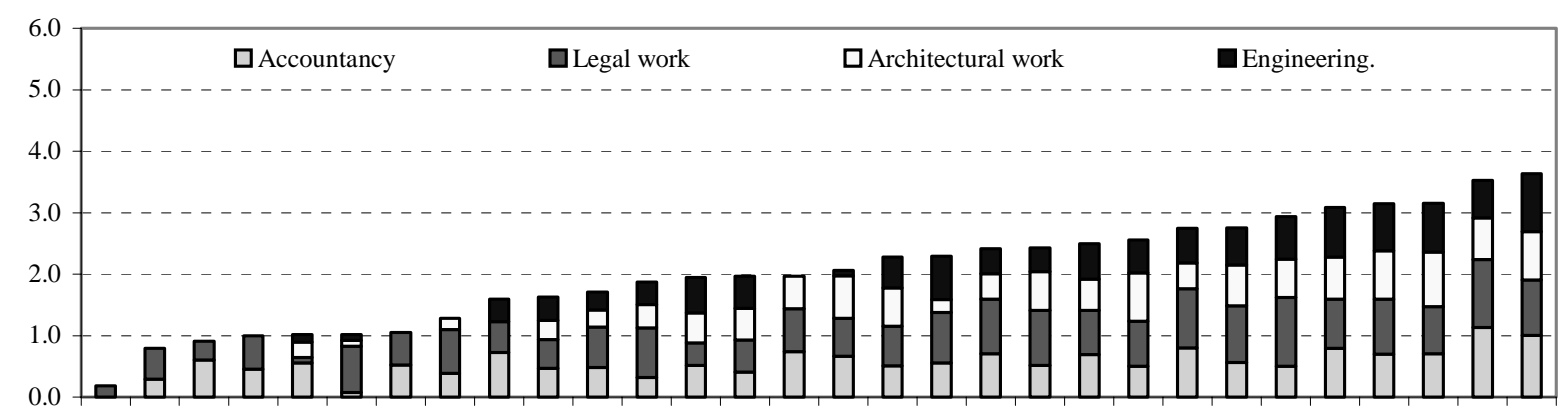

(3) $v^{0}$

\section{B. Transport, 1998}

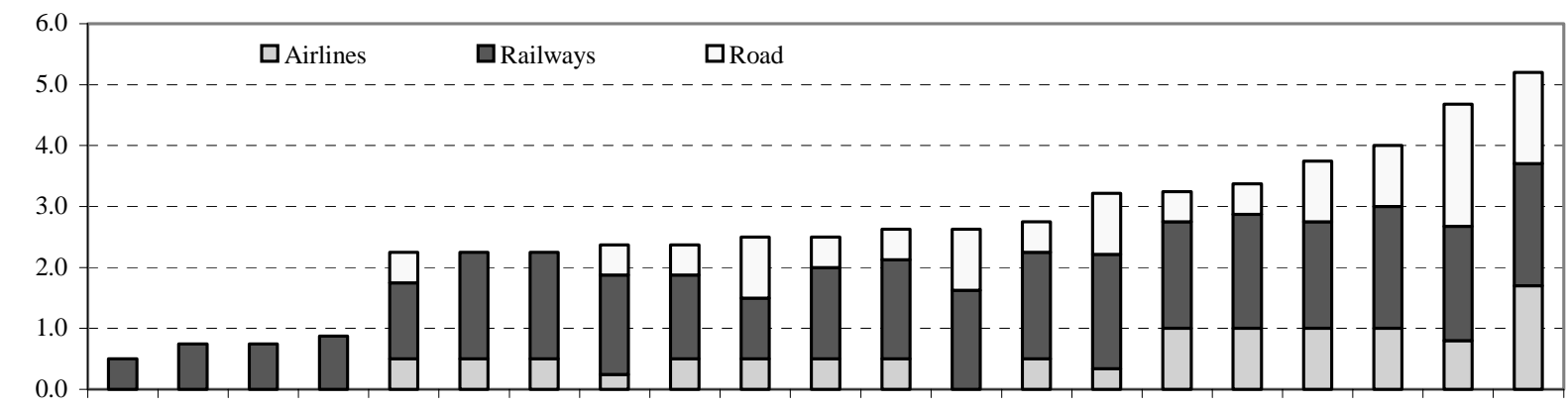

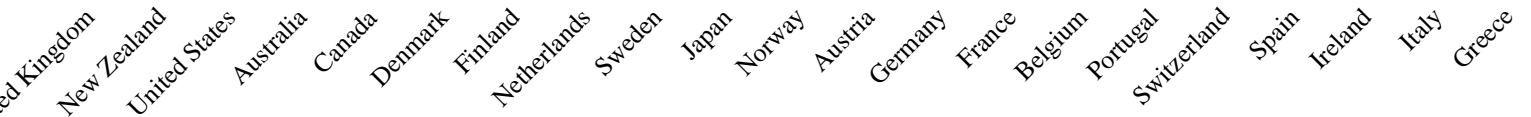

\section{Retail trade, $\mathbf{2 0 0 3}^{2}$}

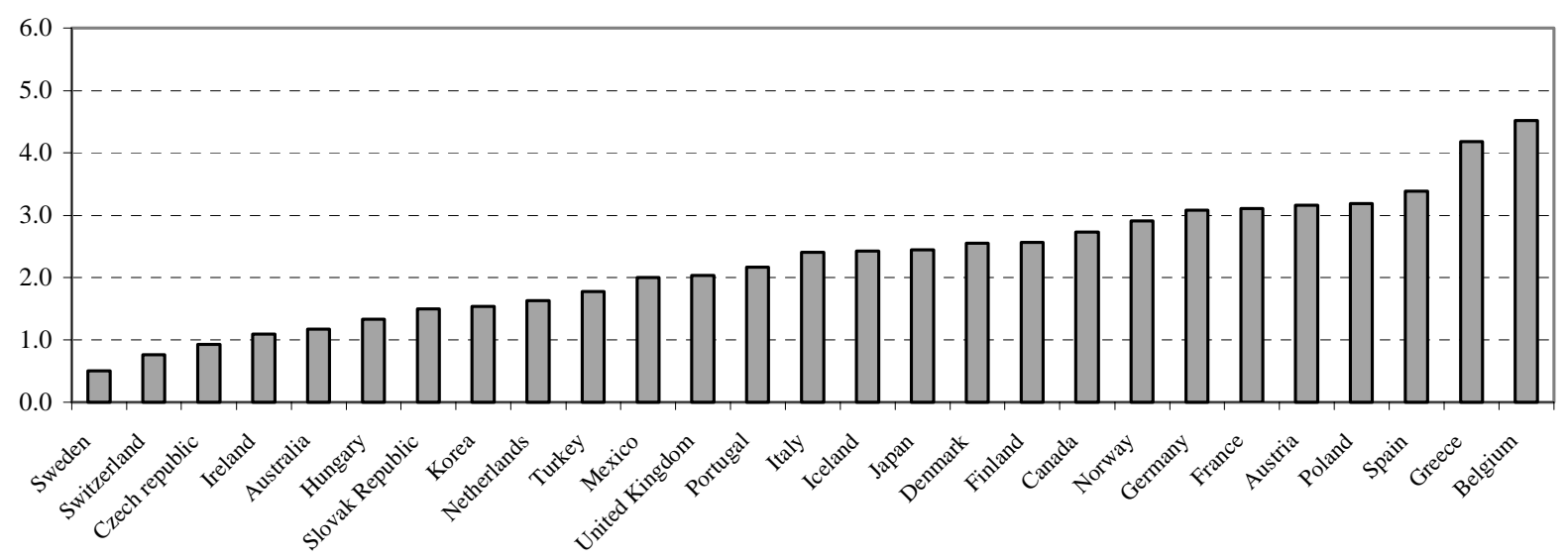

1. Index 0-6 scale from least to most restrictive.

2. Preliminary data.

3. Legal work only.

Source: OECD Product Market Regulation Database. 


\section{Regulatory reforms and their effects}

71. Countries' experiences with regulatory reforms in service markets are, on the whole, very positive. In retail trade, regulatory reforms have delivered significant economic gains. The liberalisation of the Large-Scale Retail Store Law in Japan in the early 1990s, for example, resulted in higher labour productivity, lower prices and higher retail employment, arguably boosting economy-wide GDP by around 1\% (Høj and Wise, 2004). In the Netherlands and the United Kingdom, liberalisation of opening-hours in the early-1990s led to a significant increase in employment (Centraal Planbureau, 1995) and a sharp acceleration in cyclically-adjusted value-added (Department of Trade and Industry, 2004). Similarly, deregulation of air passenger transportation and road freight has been associated with substantial gains in the form of lower prices, new services and higher labour and capital productivity (Gönenç and Nicoletti, 2001; Boylaud and Nicoletti, 2001b). In the rail sector, significant reforms have been introduced, with over half of the OECD countries now allowing independent train operators to provide services over large sections of the existing track infrastructure (OECD, 2005c). However, the experiences with regulatory reforms in this area are mixed and important issues regarding incentives and responsibilities remain to be resolved.

72. Although current regulations have often been introduced to alleviate the existence of externalities and information asymmetries in many service markets, countries' experiences suggest that feared adverse outcomes of regulatory reforms generally do not materialise. Deregulations of air and road transport have not been associated with declines in safety levels or, in the case of air transport, deprivation of small communities of air services. In road freight, in the United States and Australia after liberalisation safety seems to have improved (Boylaud and Nicoletti, 2001b). Similarly, no major increase in bankruptcy among small shops could be identified after the liberalisation of shop opening hours in the Netherlands (OECD, 2004g). Developments in telecommunications also suggest that the fulfilment of universal service obligations has not been threatened by the introduction of competition and cost-reflective tariff structures (Gönenç et al., 2001). At the same time, anti-competitive regulations in professional services have been seen to deliver higher prices and less innovation, without necessarily improving quality (Paterson et al., 2003).

\section{Recommendations given in recent $O E C D$ peer reviews}

73. Peer reviews in the OECD have recommended countries to ease anti-competitive regulations in heavily regulated service sectors. Public ownership in inherently competitive industries like air and bus transport and financial services should be reduced in several countries (including Korea, Mexico and many European countries). In retail trade, restrictions on large-scale retail outlets should be re-assessed (Austria, Denmark, France, Italy, Japan, the Netherlands and the United Kingdom), while regulations on price setting should be eased (France, Germany, Hungary and Luxembourg). Moreover, regulations instituting anti-competitive practices in professional services need to be carefully re-examined (Austria, Canada, Denmark, Germany, Hungary, Italy, the Netherlands, the Slovak Republic and Switzerland). More generally, several OECD countries, and in particular European ones, have been recommended to reduce regulatory barriers to business start-ups and firm entry, while reducing compliance costs, especially for small businesses.

\subsection{Openness and foreign competition}

\section{The impact of regulations on trade and FDI in services}

74. Opening-up domestic service markets to trade and FDI could provide more competition, bring new services to the market and create new possibilities for domestic providers through export. Recent studies have documented that foreign affiliates have a positive impact on the performance of the domestic 
economy, mainly by providing more investment and driving R\&D and productivity (e.g. Strandell, 2004). Trade in services will also allow countries to better exploit their comparative advantage, thus further lowering costs and increasing real incomes, without necessarily having significant adverse effects on domestic labour markets (Box 6). Globalisation of information and communication technology (ICT) services have, in a similar way, been seen as important in lowering ICT costs and thus spurring the adoption of ICT throughout the economy. This could boost productivity growth in ICT-using industries in all OECD countries (Mann, 2003), giving rise to similar welfare gains as did lower prices on ICT hardware in the 1990s. In the context of establishing an internal market for services in the EU, a recent study identified significant economic gains to all member states in terms of higher employment, enhanced productivity, increased wages and lower prices (Copenhagen Economics, 2005).

75. Trade and FDI in services are potentially obstructed by a number of policies, including:

- Product market regulations and licensing requirements can effectively prevent foreign firms from entering domestic service markets. Nationality or residency requirements are, for instance, relatively common in professional services, while foreign firms sometimes are prevented from carrying freight and passengers in domestic air and road transport markets (so-called cabotage). Available econometric evidence suggests that stringent regulations on FDI and barriers to trade reduce bilateral FDI stocks and service trade (e.g. Nicoletti et al., 2003).

- Cross-country heterogeneity in product market regulation has also been identified as an impediment to service FDI, by making it more costly for service firms to establish a commercial presence in another country (Kox, 2004). This could significantly reduce competition in domestic service markets and prevent or delay the introduction of new services and production methods since traditional cross-border trade in services is relatively modest (Figure 4.3).

- Uncertainties about countries' application of consumption taxes have been seen as a potential impediment to developments in international service markets, in particular for producer services (OECD, 2004h). ${ }^{24}$ While the principle that goods should be effectively zero-rated at export and taxed in the country of import is well established internationally, no accepted standard exists for taxation of service deliveries across borders. Some countries use the origin principle as the main rule, while others use the destination principle. In both cases, many exceptions typically exist. International service deliveries may thus risk double taxation or unintentional non-taxation, creating uncertainties and unnecessarily high compliance costs.

- Barriers to international e-commerce - including time delays and high handling charges because of cumbersome tax declaration - may obstruct the entry of foreign providers in domestic retail markets. Handling charges are relatively high in some OECD countries, including the Nordic ones (OECD, 2004i), significantly reducing the incentives for cross-border deliveries.

24. This includes the development of international markets for financial lease and so-called global contracts, where one firm provides services for another firm in many countries, sometimes via subcontracting. 


\section{Box 6. Globalisation of services and job losses in the service sector}

Even though there are no official statistics measuring the extent of offshoring, anecdotal evidence suggests that international sourcing of intermediate services has increased in recent years. This development has been triggered by technological advances and supported by deregulation and trade liberalisation, as well as increased supply of highlyskilled workers in several developing countries. In principle, the range of services that can potentially be offshored is significant. It includes services jobs using information technology, both low-skilled activities such as data entry, word processing and call centres, and highly-skilled activities, such as software development and professional business supports. OECD estimates place the total number of jobs that could potentially be affected by domestic or global outsourcing at close to $20 \%$ of employment in several member countries (van Welsum and Vickery, 2005).

Current estimates, which are subject to significant uncertainty, indicate that offshoring in coming years will accelerate in most OECD countries (see table below). The impact on domestic labour markets in terms of gross and net job losses is, however, likely to be modest, compared to aggregate economic activity:

- In the United States, for example, the frequently cited estimate of 3.3 million white-collar jobs moving overseas by 2015 translates into an average quarterly job-loss rate of 55000 jobs (McCarthy, 2004), which is small in comparison to the more than 7 million jobs destroyed on average every quarter over the past decade as a result of the normal functioning of the economy. ${ }^{1}$ Other OECD countries such as Germany, France and Italy are expected to see even more moderate movements of service jobs abroad than the United States.

- $\quad$ The creation of jobs abroad does not necessarily imply job losses at home. Evidence from large financial firms in the United States, for example, shows that a majority of workers affected by outsourcing are repositioned within the firm. Moreover, by raising productivity and profitability, offshoring of certain tasks can secure other domestic jobs, and thus further dampen the net impact on domestic employment possibilities.

- Jobs are also moving in both directions, as firms in developing countries import business services from the OECD area. Significant international sourcing of services also takes place within the OECD area. As a consequence, several OECD countries have actually experienced a net inflow of service jobs from offshoring in recent years (Amiti and Wei, 2004).

Many exposed service sectors, including the call centre industry, have continued to grow in terms of employment in most OECD countries, despite increased offshoring. In any case, offshoring should not permanently lower employment and production as resources are redeployed in other activities, while the short-run impact depends on countries' adjustment capacities.

Job losses in services due to offshoring. Selected estimates

\begin{tabular}{|c|c|c|}
\hline Institution & Country/region & Estimate \\
\hline \multicolumn{3}{|l|}{ Projections: } \\
\hline McCarthy (2004) & United States & A total of 3.3 million white-collar jobs expected to move offshore by 2015 . \\
\hline Parker (2004) & $\begin{array}{l}16 \text { European } \\
\text { countries }\end{array}$ & $\begin{array}{l}1.2 \text { million IT and service jobs to move to offshore locations by } 2015 \text {. UK likely } \\
\text { to be most affected, with an overall impact relatively similar to the United States, } \\
\text { while Germany, France and Italy are expected to see moderate job movements } \\
\text { offshore. }\end{array}$ \\
\hline Deloitte Research ${ }^{1}$ & $\begin{array}{l}\text { United States, } \\
\text { Western Europe }\end{array}$ & $\begin{array}{l}\text { More than } 800000 \text { financial-service jobs estimated to be lost in Western Europe } \\
\text { by } 2008 \text {, while roughly } 2 \text { million jobs could be lost by } 2009 \text { in the United States. }\end{array}$ \\
\hline \multicolumn{3}{|r|}{ 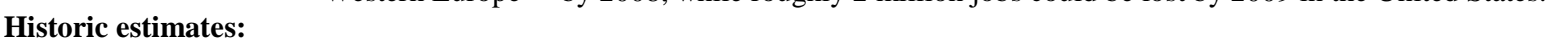 } \\
\hline McCarthy (2002) & United States & About 103000 service jobs moved offshore in 2000 \\
\hline Goldman Sachs ${ }^{1}$ & United States & Up to half a million layoffs can be attributed to offshoring in the period 2001-03 \\
\hline Global Insight (2004) & United States & A total of 104000 IT software and service jobs lost due to offshoring as of 2003 \\
\hline
\end{tabular}

1. Estimates as referred to in media reviews.

Source: As indicated in table.

1.The average loss of more than 7 million jobs refer to declines in employment in existing establishments and those which are closing down. 


\section{ECO/WKP(2005)14}

Figure 4.3. Domestic sectors' exposure to trade ${ }^{1}$

Trade relative to domestic production, average mid 1990s, per cent

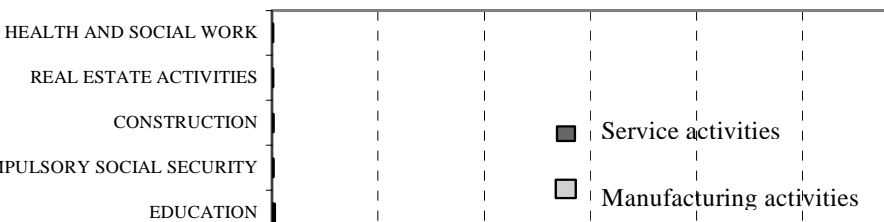

PRIVATE HOUSEHOLDS WITH EMPLOY bodies)

ELECTRICITY, GAS AND WATER SUPPLY

FINANCE, INSURANCE

RENTING OF MACHINERY AND EQUIPMENT

POST AND TELECOMMUNICATIONS

OTHER COMMUNITY, SOCIAL AND PERSONAL SERVICES

WHOLESALE AND RETAIL TRADE; REPAIRS

HOTELS AND RESTAURANTS

COMPUTER AND RELATED ACTIVITIES

OTHER BUSINESS ACTIVITIES

RESEARCH AND DEVELOPMENT

TRANSPORT AND STORAGE

AGRICULTURE, HUNTING, FORESTRY AND FISHING

FOOD PRODUCTS, BEVERAGES AND TOBACCO

PULP, PAPER, PAPER PRODUCTS, PRINTING AND PUBLISHING

OTHER NON-METALLIC MINERAL PRODUCTS

FABRICATED METAL PRODUCTS, except machinery and equipment

WOOD AND PRODUCTS OF WOOD AND CORK

COKE, REFINED PETROLEUM PRODUCTS AND NUCLEAR FUEL

MANUFACTURING NEC; RECYCLING

BUILDING AND REPAIRING OF SHIPS AND BOATS

RUBBER AND PLASTICS PRODUCTS

PHARMACEUTICALS

NON-FERROUS METALS

RAILROAD EQUIPMENT AND TRANSPORT EQUIPMENT N.E.C.

IRON \& STEEL

CHEMICALS EXCLUDING PHARMACEUTICALS

ELECTRICAL MACHINERY AND APPARATUS, NEC

MACHINERY AND EQUIPMENT, N.E.C.

TEXTILES, TEXTILE PRODUCTS, LEATHER AND FOOTWEAR

AIRCRAFT AND SPACECRAFT

RADIO, TELEVISION AND COMMUNICATION EQUIPMENT

MINING AND QUARRYING

MEDICAL, PRECISION AND OPTICAL INSTRUMENTS

MOTOR VEHICLES, TRAILERS AND SEMI-TRAILERS

OFFICE, ACCOUNTING AND COMPUTING MACHINERY

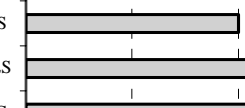

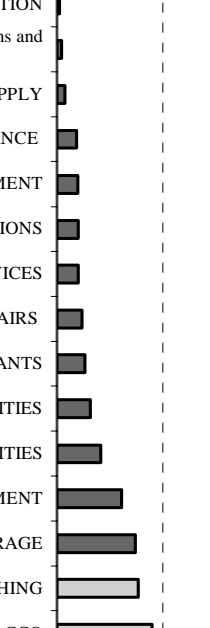
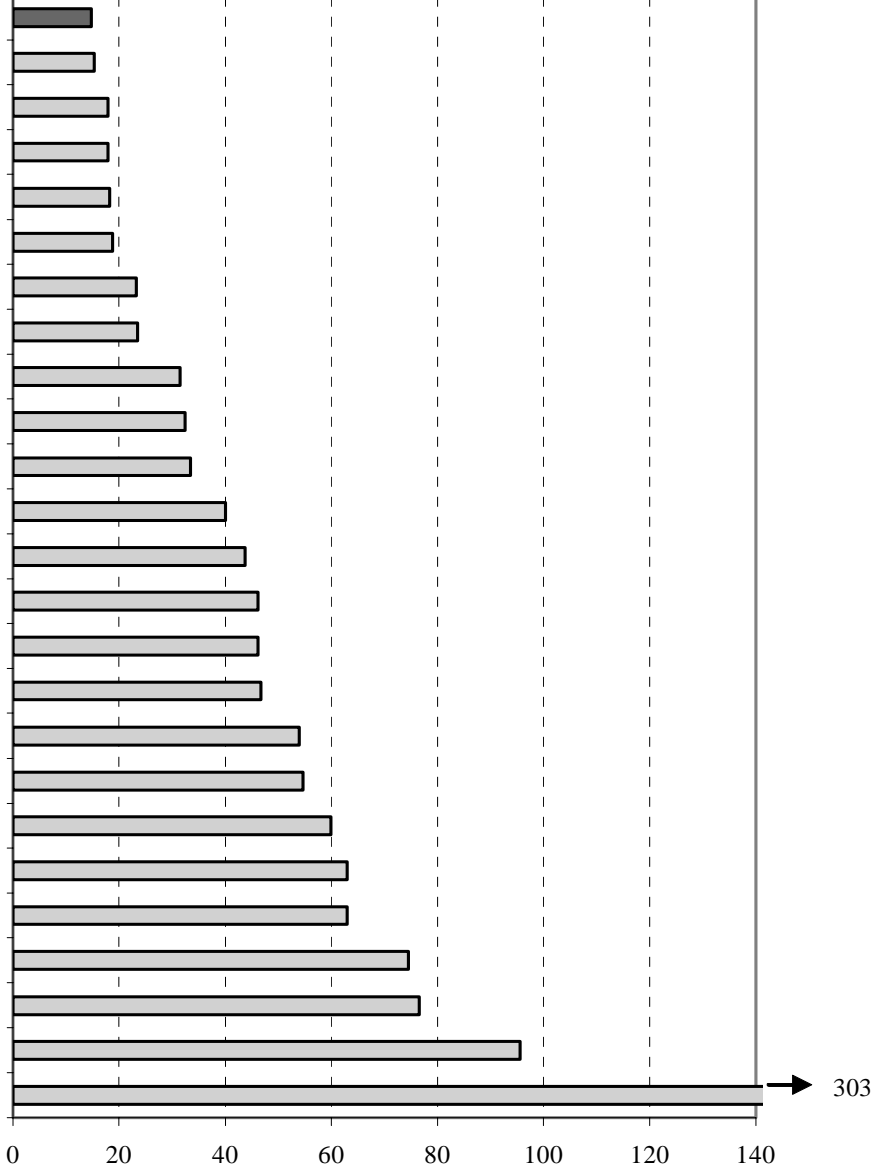

Per cent

1. Calculations are based on input-output tables using the following formula: ((Imports + exports)/2) / industrial output *100. Average of available data for Australia, Canada, Denmark, Finland, France, Germany, Greece, Italy, Japan, The Netherlands, Norway, Spain, United Kingdom, United States.

Source: OECD Input-Output Database. 


\section{The extent of regulatory barriers to trade and FDI in services}

76. Regulatory barriers to trade and investment are pronounced in several OECD countries, particularly in Mexico and Poland (Figure 4.4). ${ }^{25}$ In both these countries, relatively strict ownership barriers coincide with substantial tariffs and, in Poland, with regulatory barriers. In several other countries, significant barriers to foreign ownership go hand-in-hand with less restrictive policies in other areas (including New Zealand, Canada and Italy). Barriers to FDI are also substantial in several service markets (Figure 4.5), mainly reflecting foreign ownership restrictions and public ownership. ${ }^{26}$ In the late $1990 \mathrm{~s}$, FDI barriers were particularly stringent in telecommunications (Iceland and Turkey), transport (Canada and the United States) and finance (Canada, Iceland and Korea).

Figure 4.4. Barriers to foreign trade and investment ${ }^{1}$

Regulation in 2003

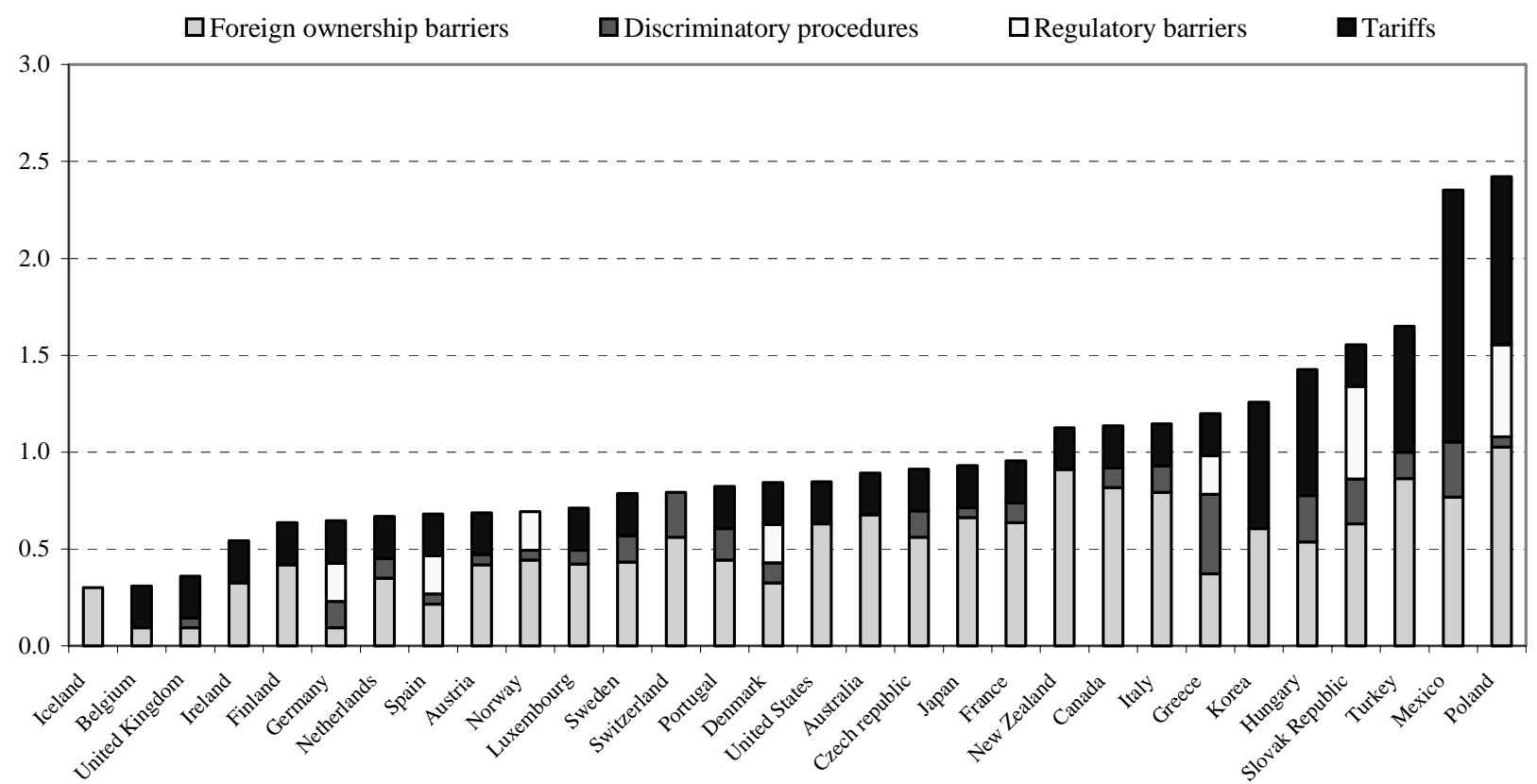

1. Index 0-6 scale from least to most restrictive. The indicators refer to economy-wide regulations.

Source: OECD Product Market Regulation Database.

25. See Conway et al. (2005) for more details about this indicator. Note that the data refer to 2003 and thus do not incorporate changes since then. This is likely to influence the stance of policy in some countries, notably the new EU member states.

26. These indicators ignore most of the other direct or indirect obstacles impeding on FDI, such as those related to corporate governance mechanisms and hidden institutional or behavioural obstacles that discriminates against foreign firms (Golub, 2003). 
Figure 4.5. FDI regulations in selected services industries ${ }^{1}$ 1998-2000

\section{A. Business services}
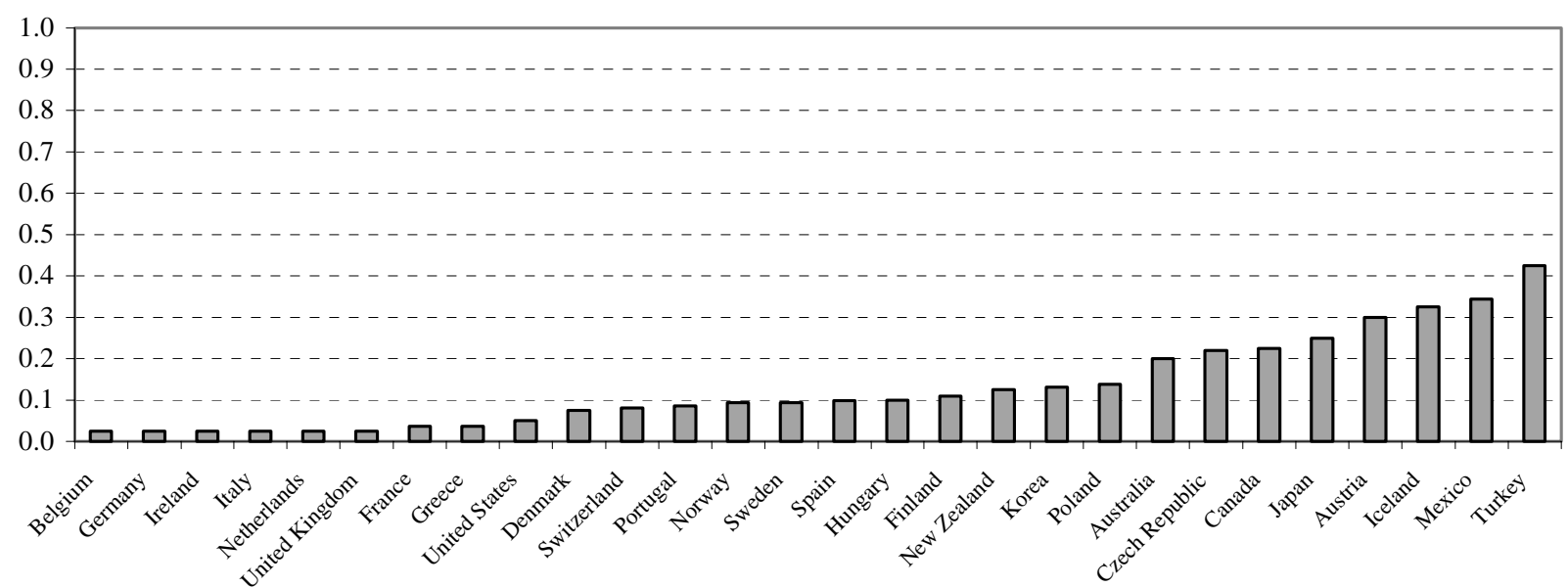

\section{B. Telecommunications}
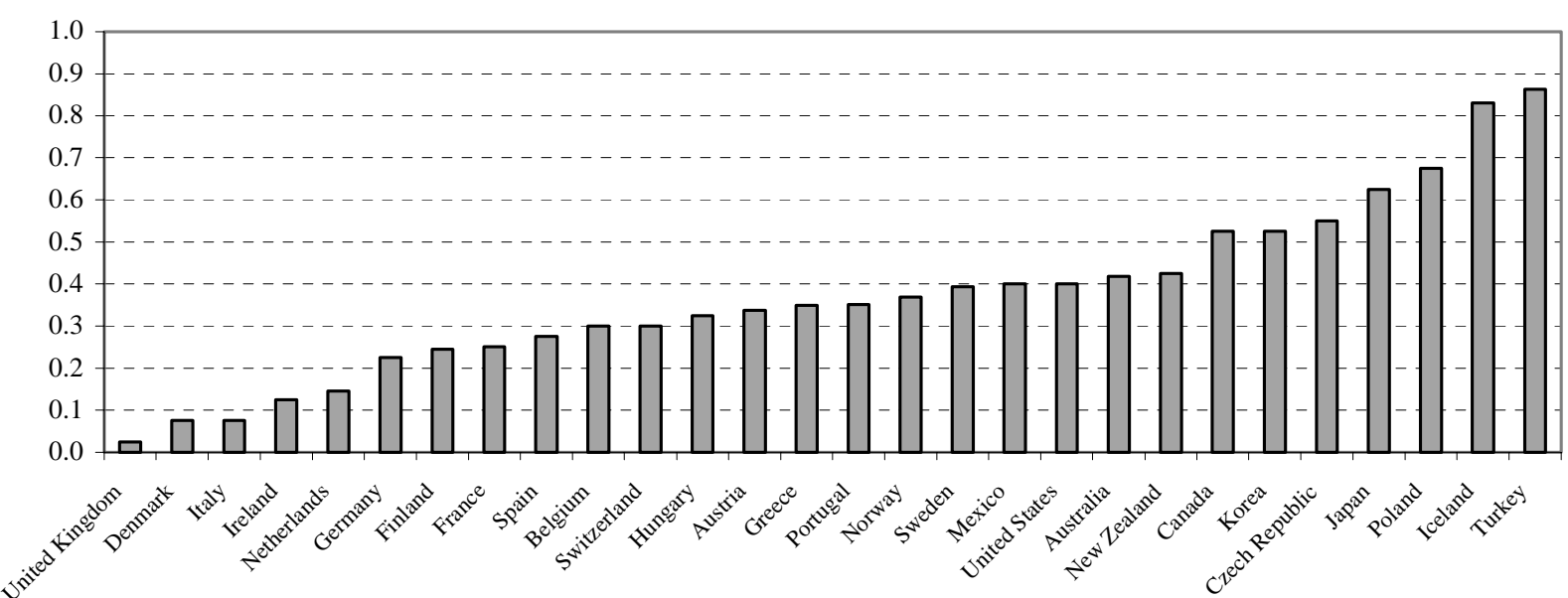

\section{Distribution}

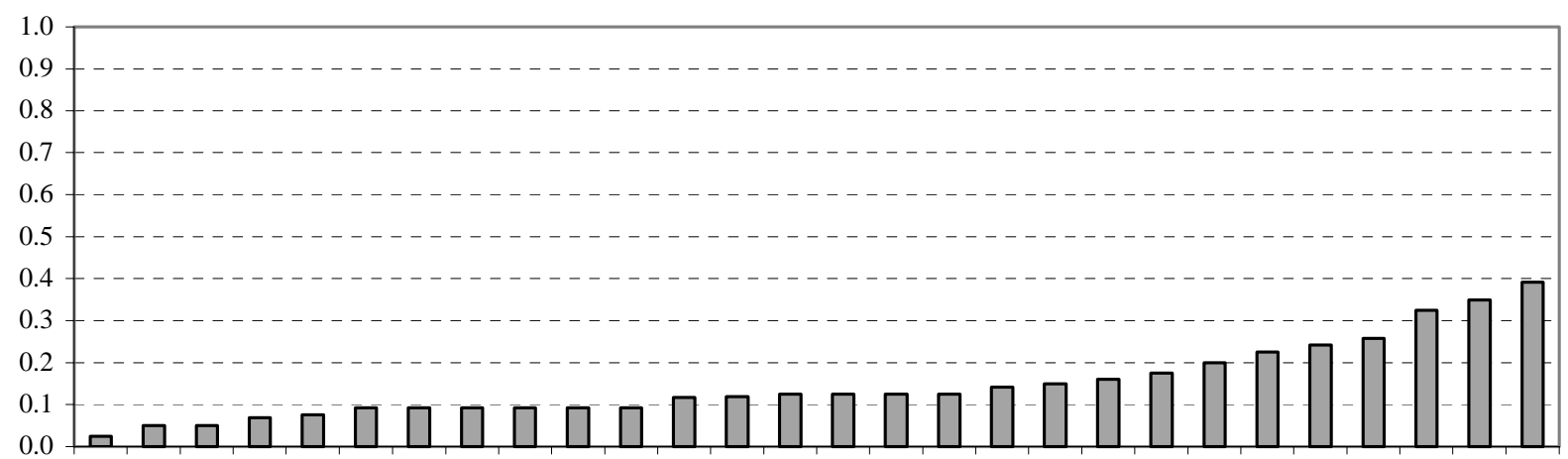

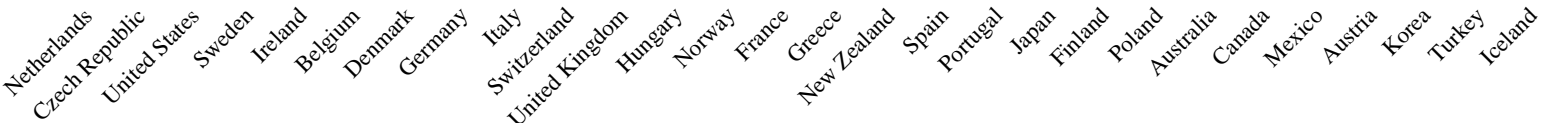

1. The indicator ranges from 0 (least restrictive) to 1 (most restrictive). Source: Golub (2003). 
Figure 4.5. FDI regulations in selected services industries ${ }^{1}$ (cont.) 1998-2000

\section{Finance}

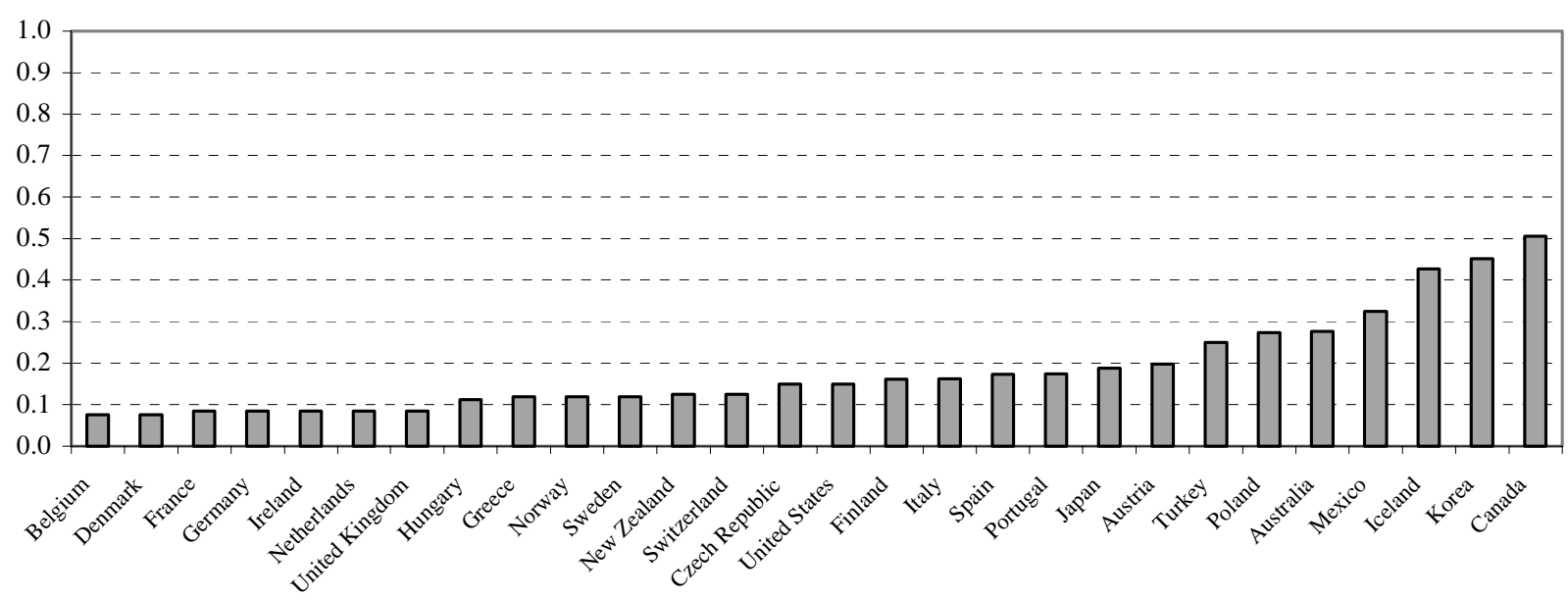

\section{E. Hotels and restaurants}
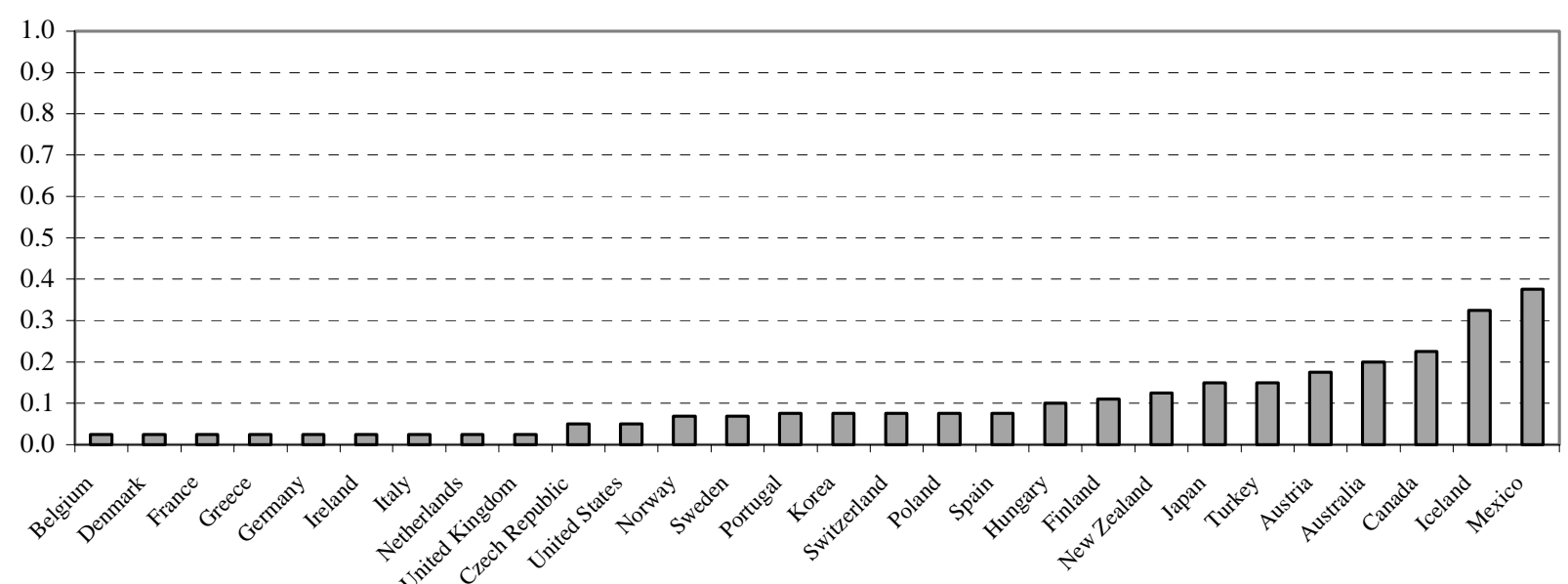

\section{F. Transports}

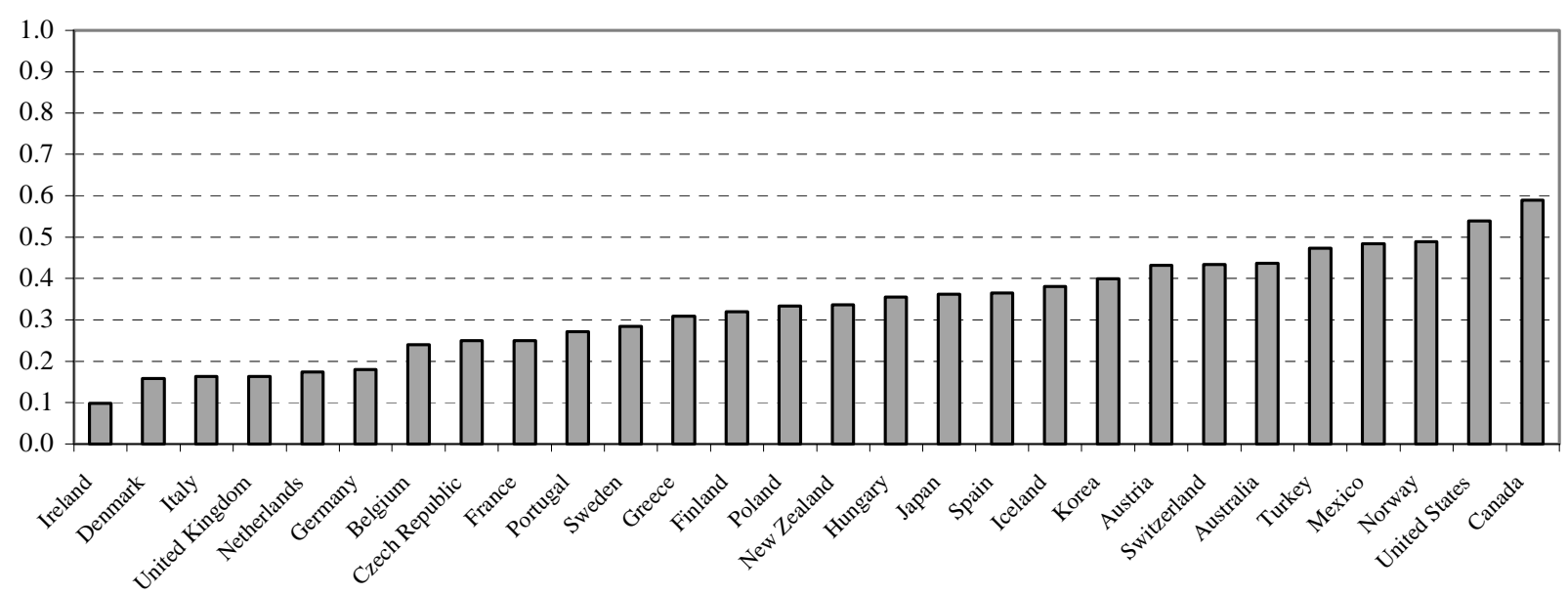

1. The indicator ranges from 0 (least restrictive) to 1 (most restrictive). Source: Golub (2003). 


\section{ECO/WKP(2005)14}

\section{An unfinished agenda}

77. Peer-reviews in the OECD have recommended several countries to reduce restrictions to foreign ownership in important service markets (Canada, Iceland, Japan, Korea, Mexico, New Zealand and Poland). A few countries have also been explicitly advised to ease restrictions on cross-border provision of services, for example by lifting restrictions on cabotage in road and air transport. Furthermore, all OECD countries need to ensure a transparent framework for cross-border deliveries of services. As set out in the Ottawa Taxation Framework Conditions for e-commerce, this includes certainty about tax obligations for producers and customers, neutrality between different providers and vis-à-vis traditional commerce, and as few administrative costs as possible. In this respect, all OECD countries have recently been advised to establish international guidelines for the application of consumption taxes. ${ }^{27}$

\subsection{Enhancing the efficiency of social services}

\section{Encouraging competition in social services}

78. Social service activities - including core government administration, education and health - are characterised by heavy regulation and substantial direct public involvement in all OECD countries. Many social services are thus provided in a non-competitive environment and are often free of charge for the user at the point of delivery. The absence of a price mechanism implies that it is difficult to gauge demand, and thus to assess if the optimal level of social services are provided in each country. However, more can be said regarding the efficiency in the provision of social services. In particular, policies to encourage competition and strengthen the role of market mechanisms have been seen as instrumental in enhancing efficiency in social services, although there are limits to their use.

79. Allowing users a choice among alternative providers of publicly-funded services can strengthen competitive pressures, stimulate innovation and result in services which respond better to citizens' needs (Joumard et al., 2003). Introducing free choice can be particularly useful where there are difficulties in assessing the actual quality of publicly-funded services, as it then imposes a market test on providers. One important condition for competitive pressures to be effective is the implementation of the money-followsthe-user principle, allowing successful providers to expand their activity. User choice may, however, also have some unwanted effects by, for instance, opening up for more social segmentation in schools. ${ }^{28}$

80. Providing information to consumers and providers on quality and cost is an alternative means to impose competitive pressures on social services providers. By allowing comparisons to be made across providers of similar services, benchmarking can put consumers, providers and the government in a better position to make informed decisions. It can also create incentives for providers to improve their performance, in particular if combined with free user choice and supportive funding arrangements (i.e. money-follows-the-user principle or performance-based funding). But publication of results may have some drawbacks. In the case of school results, for example, it may lead privileged families to shun schools with a "worse" intake by making parents more aware of the variations in the social and academic profiles of students. Moreover, as valid performance measures are not easy to design, providing performance

27. The OECD Working Party on Consumption Taxes recommended in 2004 countries to create and adopt a set of framework principles for the application of consumption taxes to internationally-traded services and intangibles (OECD, 2004h).

28. In countries with a private and competitive market in employment services (including Australia and the Netherlands), the degree of free choice is often limited for the unemployed. This is to alleviate the risk that the unemployed choose providers that impose few requirements on e.g. job search. Service providers may also have stronger incentives to provide adequate training to clients if they stay long-term with the same provider (Grubb, 2003). 
information may risk guiding providers to focus efforts for improvements only on those aspects that can be easily measured.

81. While a clear case may exist for the government to ensure equal access to key social services, this does not require the government to be the only provider of these services. Relaxing entry restrictions for private providers may help strengthen competition, in particular when combined with free user choice and non-discriminatory funding arrangements. Several studies have documented positive effects of user choice and competition on performance in primary and secondary education, child care and long-term care (Lundsgaard, 2002). The performance of public schools has, for instance, been found to improve when exposed to competition, while a positive impact in terms of greater flexibility and lower costs have been identified in long-term care. However, to be effective, funding arrangements need to provide for variations in delivery costs across user groups. This could also reduce the scope for "cream-skimming", i.e. that some providers are able to make a profit or provide higher service standards by attracting individuals that are less costly.

82. Sub-contracting and competitive tendering may further enhance efficiency in the provision of social services, and in particular the production of intermediate inputs, by exploiting economies of scale and specialisation. Indeed, empirical studies generally find that competitive tendering results in lower costs than under uncontested public provision. Contracting out, however, also implies costs, especially when the output being purchased is complex and may entail the risk of cost overruns, which may be borne by the public sector, if the contractor fails to deliver or threatens to go into bankruptcy.

\section{The use of market mechanisms in the provision of social services}

83. Measuring the extent of competition and efficiency in social service industries are fraught with problems. Available information suggests, however, significant cross-country variations. The extent of free user choice seems, for instance, to vary considerably among countries (Figure 4.6), despite being an important policy objective in a number of countries over the past decade. ${ }^{29}$

Figure 4.6. The extent of free choice of government financed services ${ }^{1}$

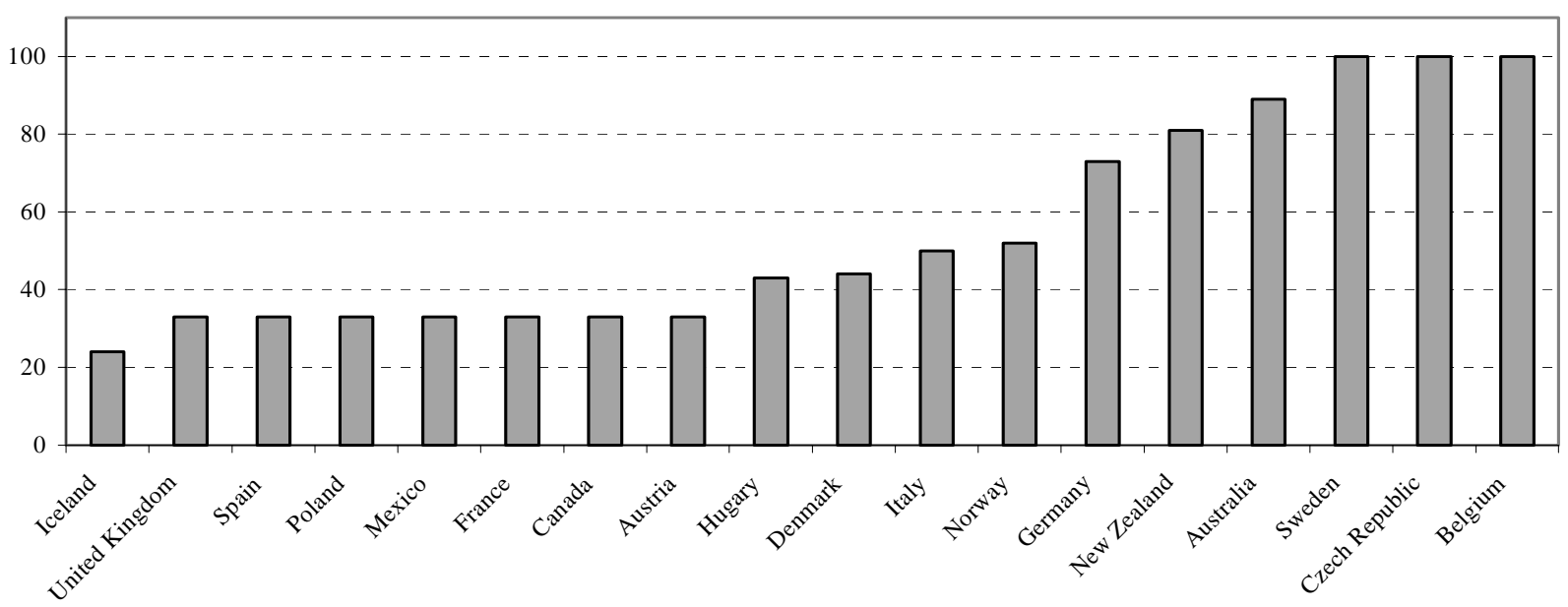

1. The index shows a relative scale where the countries with most freedom of choice have index $=100$; that does not mean they have free choice for all services. The index reflects the extent of free choice in hospitals, dentists, general practitioners, nursing homes, kindergartens and home help, as reported in questionnaires by consumer authorities in the various countries.

Source: OECD Economic Surveys for Denmark 2005.

29. Benchmarking has been increasingly used in all OECD countries to identify best practices and inefficiencies in a wide range of social services, including hospitals, education institutions, employment services and prisons. However, no cross-country information about their overall application is easily available. 


\section{ECO/WKP(2005)14}

84. Similarly, the market share of private providers varies considerably in important social service markets:

- In hospital care, the share of private in-patient beds varies from close to zero in Norway and Poland to 60\% in Australia and Japan and more than 90\% in Korea (Figure 4.7, Panel A).

- In elderly care, OECD countries are found all along the spectrum from predominantly private providers in countries like Australia, Germany, Japan and the United States to predominantly public providers in the Nordic countries (Figure 4.7, Panel B).

- In child care, the share of private institutions range from less than 5\% in Denmark and 10\% in Finland to more than $60 \%$ in Australia, Japan and the Netherlands (Figure 4.7, Panel C). Independent private institutions - i.e. private institutions that are financed mainly by household payments - are, however, rare except in Japan and Spain.

- In upper secondary education, the share of students enrolled in private institutions varies from a few per cent in Ireland, Sweden and Turkey to close to $75 \%$ in the United Kingdom and more than $90 \%$ in the Netherlands (Figure 4.7, Panel D). Independent private institutions are mainly found in Japan, Mexico, Portugal and Spain.

- In tertiary education, the share of students enrolled in private institutions ranges from close to zero in Denmark and the Slovak Republic to close to $80 \%$ in Korea and $100 \%$ in the United Kingdom (Figure 4.7, Panel E). Independent private institutions are, in general, more common in tertiary education than in child care and upper-secondary education, and represent a particularly large share of the market in Japan and Korea.

- In core employment services, Australia and the Netherlands established a fully private market in the late 1990s (Grubb, 2003). In many other countries, core employment services are delivered by a sole public provider.

- The extent of sub-contracting and competitive tendering in public procurement differs also widely across countries. Within the European Union, the share of public procurement openly advertised for tender varied from around 3\% in Germany to 12\% in Greece in 2002 (Figure 4.7, Panel F).

85. The significant cross-country variations documented above, even among countries that share similar social norms and preferences, suggest that these differences do not reflect equity or other legitimate concerns but to a larger extent is rooted in history. In this respect, the findings above suggest a significant scope for more experimentation and increased use of market mechanisms and competition in social services in several OECD countries. 
Figure 4.7. Private providers: market shares in selected services ${ }^{1}$

\section{A. Private in-patient beds, $2000^{2}$}

$\%$ of total beds

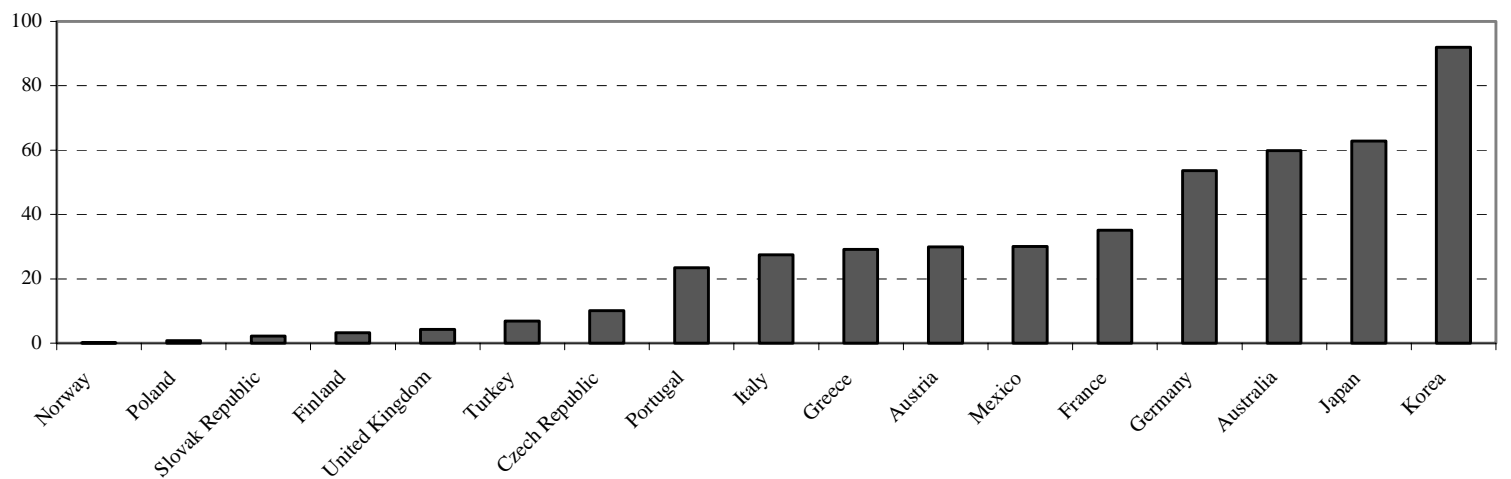

B. Nursing homes for older persons, late 1990s

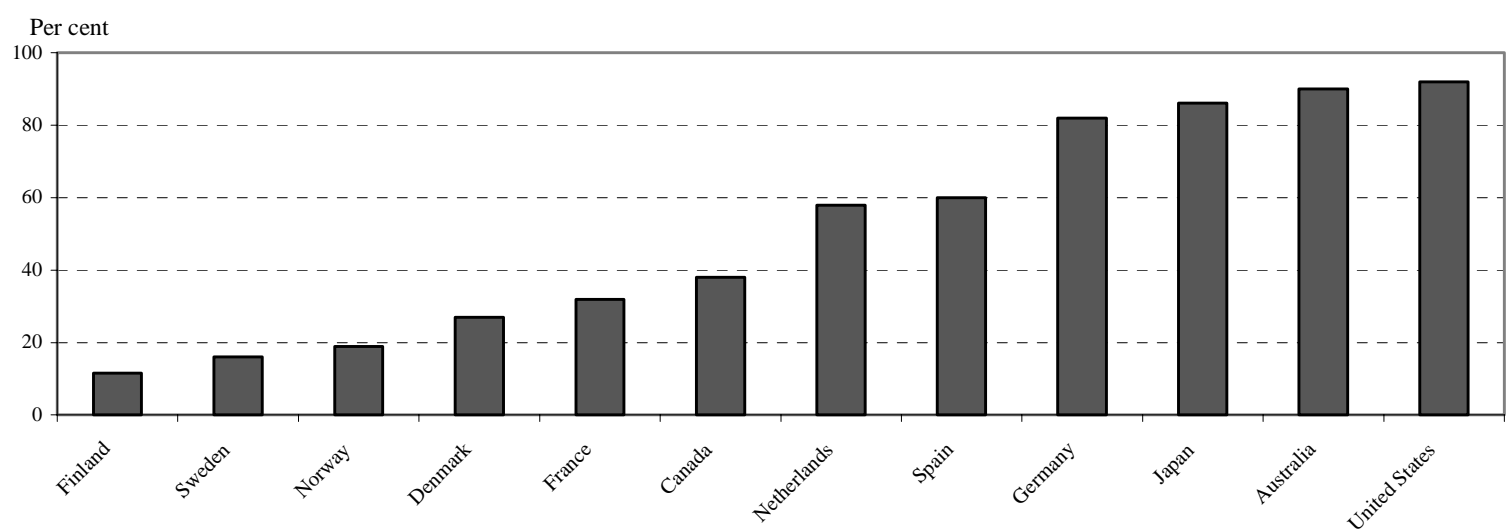

C. Child care institutions, $2001^{3}$

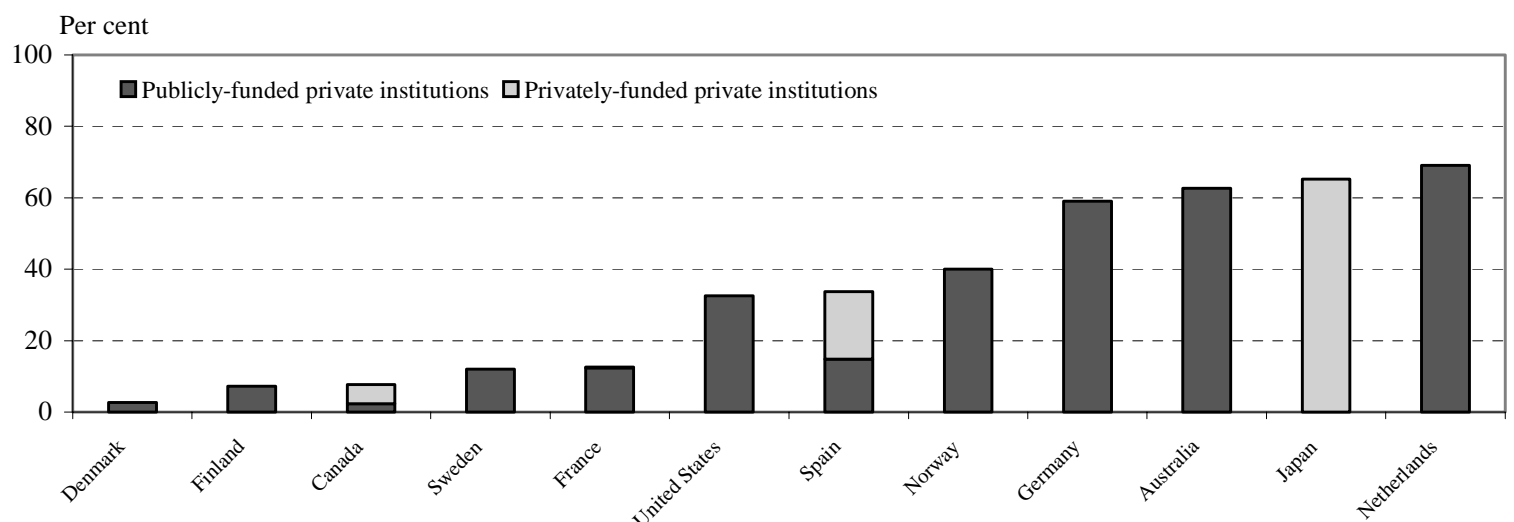

1. Private institutions include both non-profit institutions and private firms.

2. 1999 in the case of Australia, Greece, Italy, Portugal and the United Kingdom.

3. Includes pre-primary education and organised centre-based programmes designed to foster learning and emotional and social development in children from 3 years to compulsory school age. For Australia, Germany and Norway some of the private institutions may be predominantly privately funded, but the available data cannot determine the exact share of private and public funding for private institutions.

Source: OECD Health Database (2002), OECD Education database (2004) and OECD Economic Survey for Finland 2004. 
Figure 4.7. Private providers: market shares in selected services ${ }^{1}$ (cont.)

\section{Students enrolled in private institutions: Upper secondary education, 2002}

$\%$ of total students

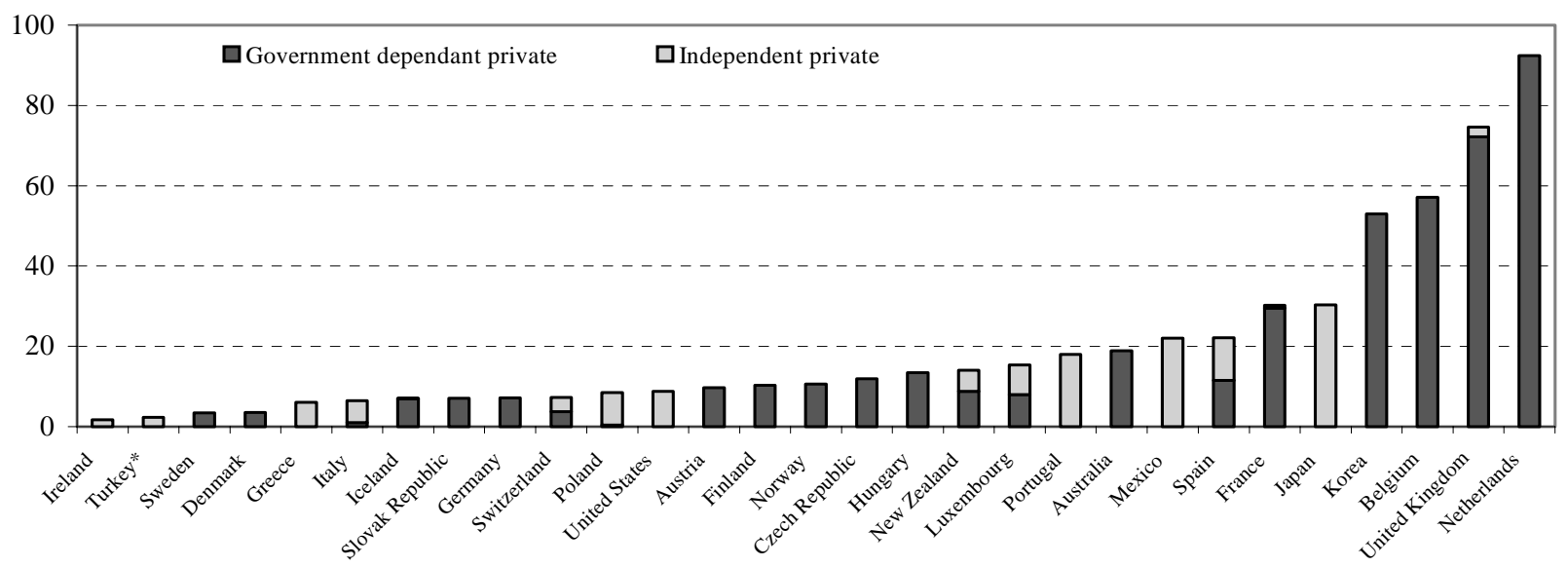

E. Students enrolled in private institutions: Tertiary education, $\mathbf{2 0 0 2}^{2}$

$\%$ of total students

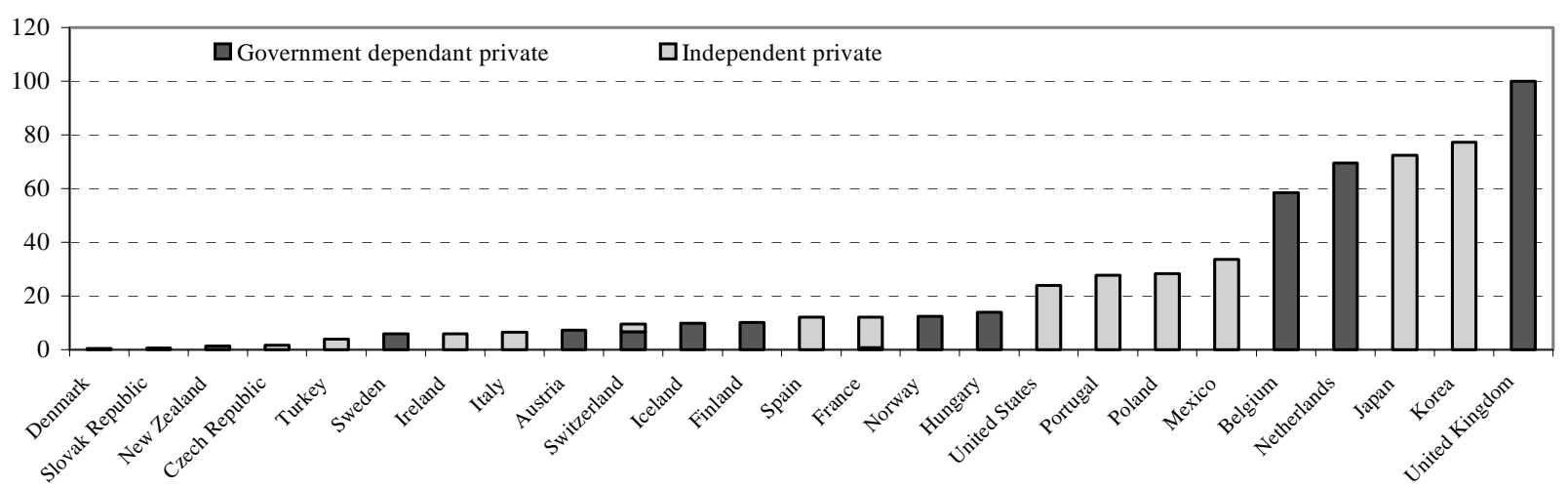

\section{F. Openly advertised public procurement, 2002}

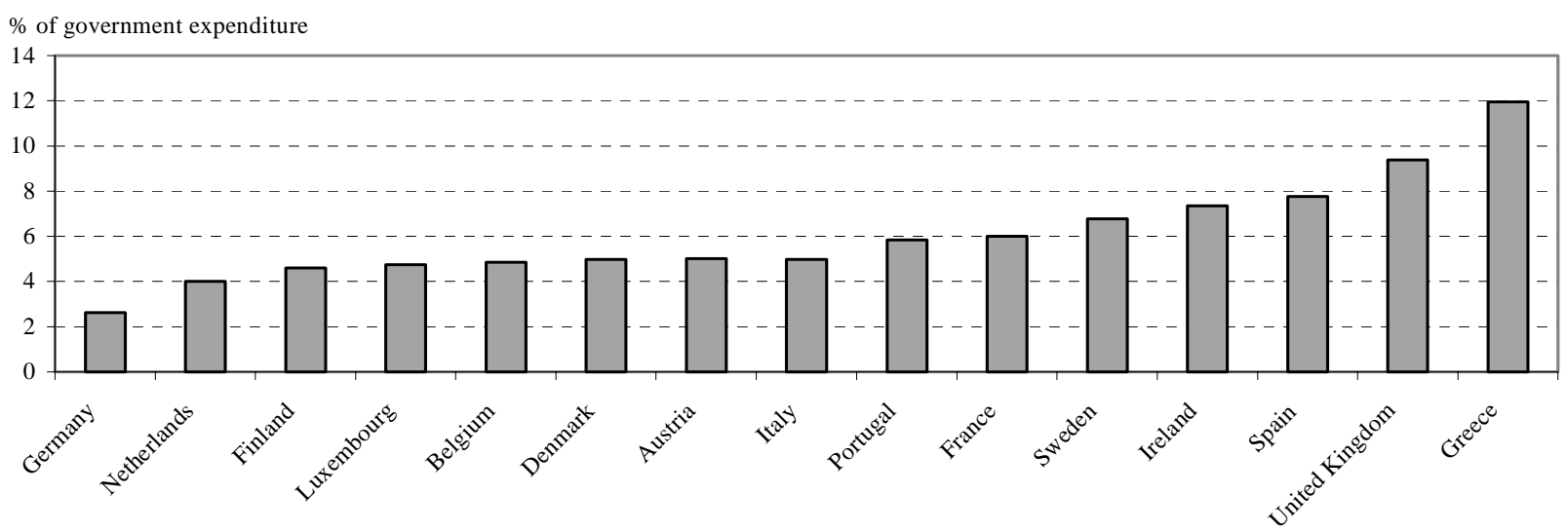

1. Based on the number of users in each type of institution. Private institutions include both non-profit institutions and private firms. 2. Includes largely theory-based programmes that are designed to provide sufficient qualifications for entry to advanced research programmes and professions with high skill requirements, such as medicine, dentistry or architecture. Usually includes both Bachelor and Masters degrees and their equivalent.

Source: OECD Health Database (2002), OECD Education database (2004), OECD Economic Survey for Finland 2004 and OECD Economic Surveys for Denmark 2005. 


\section{Recommendations for further action}

86. To enhance efficiency in the social service sector, several OECD countries have recently been advised to further strengthen the role of market signals. This includes an opening-up for private providers (Greece, Luxembourg, New Zealand, Norway and Poland), strengthening of user choice (Denmark, Finland, Korea, Norway and Portugal) and applying more consistently the "money-follows-the-user" principle (Finland, New Zealand, Norway, Poland, Sweden and Switzerland). Greater use of outsourcing has been recommended for Denmark, Finland, Hungary, Iceland, Ireland, Italy, Luxembourg, Korea, Mexico, New Zealand, Norway and Portugal.

\section{Policy settings and performance: Concluding remarks}

87. Section 2 in this report developed two simple indicators of performance that summed-up: i) the capacity of countries to adjust their labour markets and ii) the capacity to foster the service sector. Countries' policy settings can likewise be summarised as the average country rank on the policy indicators presented in Sections 3 and 4. The following policy areas are included: replacement rates in unemployment benefit systems, employment protection legislation, wage setting systems, education and training indicators, labour taxes, anti-competitive regulations and barriers to trade and investment. ${ }^{30}$ However, as noted in section 2, such summary indicators are imperfect and need to be interpreted with caution. They are all based on an element of judgement and are constrained by data availability, implying that important aspects might be missing. Moreover, they are all calculated as a simple average of countries' rankings based on a number of sub-indicators, i.e. with no attempt to weight their relative importance.

88. The relationship between the policy indicator and the two performance indicators is to a large extent as expected:

- Countries with an overall policy setting that should be favourable to structural change tend to adjust relatively smoothly in labour markets (Figure 5.1, Panel A). This country group includes Australia, New Zealand, the United Kingdom and the United States. Similarly, countries with a relatively poor ranking on the policy indicator seem to have less capacity to adjust in labour markets (including France, Greece and Italy). The main exception to this broad-brush picture is Norway, with a relatively strong adjustment capacity in the labour market but only a medium rank on the policy indicator.

- A positive association can also be identified between the policy indicator and the indicator for service sector developments (Figure 5.1, Panel B), although it is less clear than the relationship above. A few countries with a policy setting supposed to be favourable to structural change stand-out with comparatively large income-adjusted service sectors (including New Zealand, the United Kingdom and the United States). At the other end of the spectrum, some countries with a relatively poor ranking on the policy indicator tend to have a less-developed service sector (Italy, Spain and Portugal). However, significant differences exist between countries with roughly similar overall policy settings.

30. If more than one indicator is presented, the average score is first calculated in each area. See Appendix 5 for details. 
Figure 5.1. Policy settings and countries' capacities to adjust

Average country score ${ }^{1}$

A. Policy settings and countries'capacities to adjust in labour markets

Capacity to adjust in labour

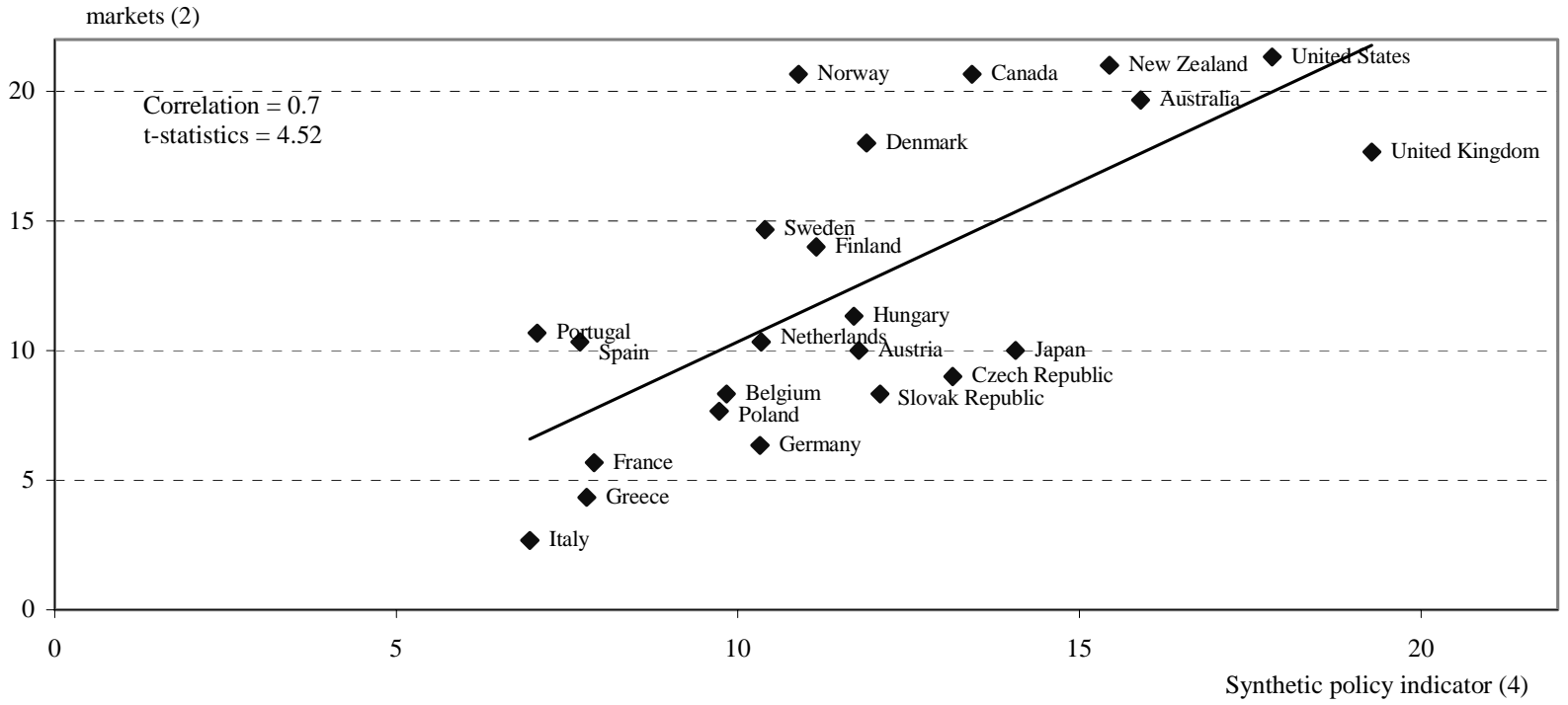

B. Policy settings and countries'capacities to expand in services

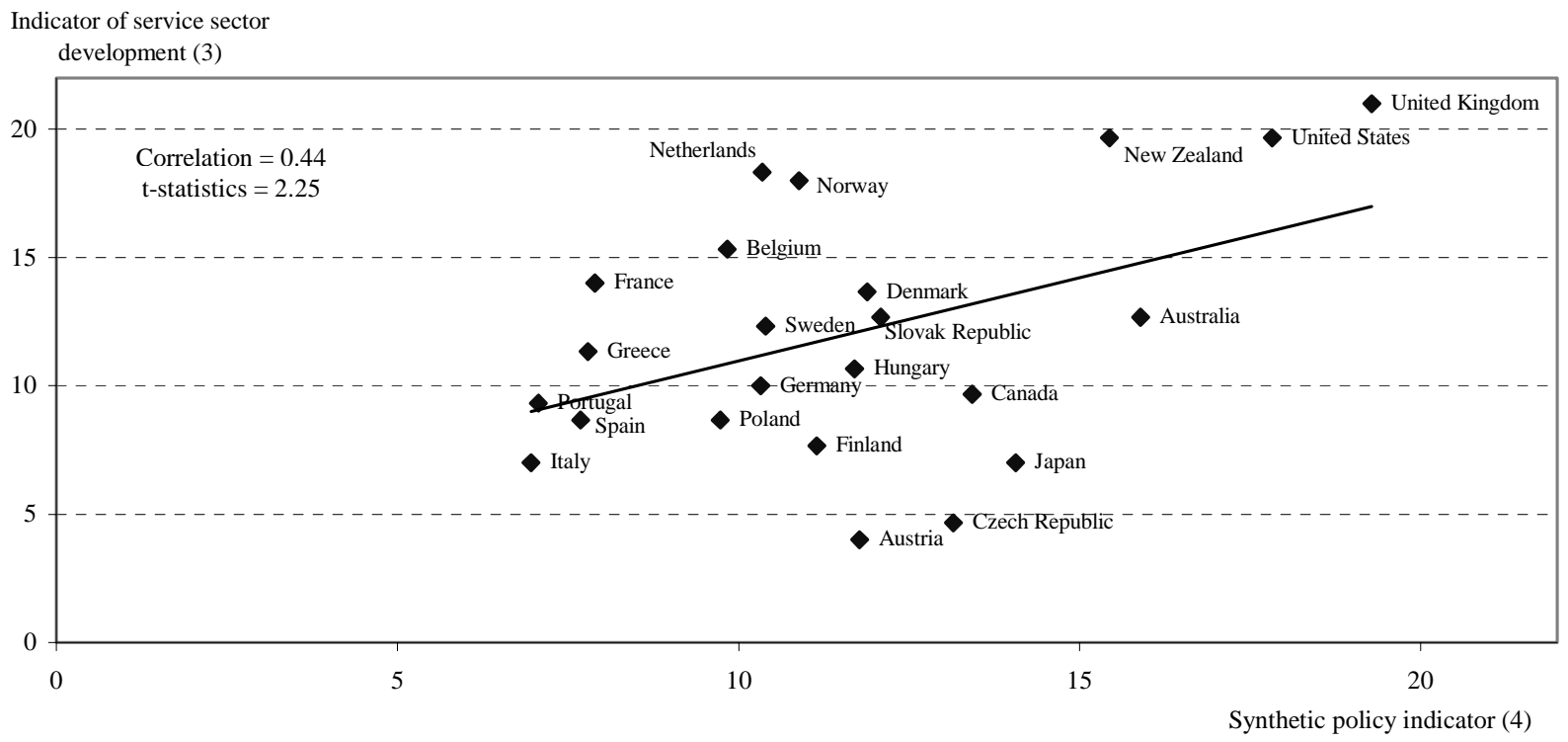

1. Note that most policy indicators refer to 2003 (or 2002) and do not incorporate changes since then. This is likely to influence the stance of policy in some countries, notably the new EU member countries.

2. A high score indicates relatively high adjustment capacity.

3. A high value indicates a relatively large service sector.

4. A high value indicates relatively favourable policy settings.

Source: OECD calculations. 
ECO/WKP(2005)14

APPENDIX 1

SECTORAL CLASSIFICATION AND DATA AVAILABILITY

Table A1.1. Sectoral classification

\begin{tabular}{|c|c|}
\hline Sector & ISIC rev. 3.0 (2-digit level) \\
\hline Total & 01-99 \\
\hline $\begin{array}{l}\text { Primary industries } \\
\text { Agriculture, hunting, forestry and fishing } \\
\text { Mining and quarrying } \\
\text { Electricity, gas and water supply }{ }^{1} \\
\text { Construction }\end{array}$ & $\begin{array}{r}01-05 \\
10-14 \\
40-41 \\
45\end{array}$ \\
\hline $\begin{array}{l}\text { Secondary industries } \\
\text { Total manufacturing }\end{array}$ & $15-37$ \\
\hline $\begin{array}{r}\text { Tertiary industries } \\
\text { Total services }\end{array}$ & $50-99$ \\
\hline $\begin{array}{l}\text { Producer services } \\
\text { Business and professional services } \\
\text { Financial services } \\
\text { Insurance } \\
\text { Real estate }\end{array}$ & $\begin{array}{r}71-74 \\
65,67 \\
66 \\
70\end{array}$ \\
\hline $\begin{array}{l}\text { Distributive services } \\
\text { Retail trade } \\
\text { Wholesale trade } \\
\text { Transportation } \\
\text { Communication }\end{array}$ & $\begin{array}{r}50,52 \\
51 \\
60-63 \\
64\end{array}$ \\
\hline $\begin{array}{l}\text { Personal services } \\
\text { Hotels and restaurants } \\
\text { Recreational and cultural services } \\
\text { Domestic services } \\
\text { Other personal services }\end{array}$ & $\begin{array}{l}55 \\
92 \\
95 \\
93\end{array}$ \\
\hline $\begin{array}{l}\text { Social services } \\
\text { Government proper } \\
\text { Health services } \\
\text { Educational services } \\
\text { Miscellaneous social services }\end{array}$ & $\begin{array}{r}75,99 \\
85 \\
80 \\
90-91\end{array}$ \\
\hline
\end{tabular}

1. Construction and electricity, gas and water supply have been classified together with primary industries so as to use standard classifications of manufacturing and services industries.

Source: The OECD STAN database for Industrial Analysis. 
Table A1.2. data availability in the OECD STAN Database for Industrial Analysis

\begin{tabular}{|c|c|c|c|c|c|c|c|}
\hline & \multirow[t]{2}{*}{ Total } & \multirow{2}{*}{ Manufacturing } & \multirow[t]{2}{*}{ Services } & \multicolumn{4}{|c|}{ Service sub-sectors } \\
\hline & & & & $\begin{array}{c}\text { Distributive } \\
\text { services }\end{array}$ & $\begin{array}{c}\text { Producer } \\
\text { services }\end{array}$ & Social services & $\begin{array}{c}\text { Personal } \\
\text { services }\end{array}$ \\
\hline Australia & $1970-2001$ & $1970-2001$ & 1971-2001 & $1970-2001$ & 1980-2001 & 1980-2001 & 1980-2001 \\
\hline Austria & 1976-2002 & $1970-2002$ & 1976-2002 & 1976-2002 & 1976-2002 & 1976-2002 & 1976-2002 \\
\hline Belgium & 1970-2002 & $1970-2002$ & $1970-2002$ & $1980-2002$ & 1995-2002 & $1995-2002$ & $1995-2002$ \\
\hline Canada & 1970-2002 & $1970-2002$ & $1970-2002$ & $1980-2002$ & $1980-2002$ & 1981-2002 & $1981-2002$ \\
\hline Czech Republic & 1995-2003 & $1995-2003$ & $1995-2003$ & $1995-2003$ & $1995-2003$ & $1995-2003$ & $1995-2003$ \\
\hline Denmark & 1970-2002 & $1970-2002$ & 1970-2002 & 1970-2002 & 1970-2002 & 1970-2002 & $1970-2002$ \\
\hline Finland & $1970-2003$ & $1970-2003$ & $1970-2003$ & $1975-2003$ & $1975-2003$ & $1975-2003$ & $1975-2003$ \\
\hline France & $1970-2003$ & $1970-2002$ & $1970-2002$ & 1978-2002 & 1978-2002 & 1978-2002 & $1978-2002$ \\
\hline Germany & 1991-2003 & $1991-2003$ & $1991-2003$ & $1991-2003$ & 1991-2003 & $1991-2003$ & $1991-2003$ \\
\hline Greece & $1995-2002$ & $1995-2002$ & $1995-2002$ & $1995-2002$ & 1995-2002 & $1995-2002$ & $1995-2002$ \\
\hline Hungary & 1992-2002 & $1992-2002$ & $1992-2002$ & 1992-2002 & 1992-2002 & 1992-2002 & nd-nd \\
\hline Italy & $1970-2003$ & $1970-2003$ & $1970-2003$ & $1970-2003$ & $1970-2003$ & $1970-2003$ & $1970-2003$ \\
\hline Japan & 1970-2002 & $1970-2002$ & $1981-2002$ & nd-nd & 1981-2001 & 1981-1998 & nd-nd \\
\hline Korea & 1970-2001 & 1970-2001 & $1970-2001$ & $1992-2001$ & 1992-2001 & 1992-2001 & $1992-2001$ \\
\hline Luxembourg & $1985-2003$ & $1985-2003$ & $1985-2003$ & $1985-2003$ & $1985-2003$ & $1985-2003$ & $1985-2003$ \\
\hline Mexico & nd-nd & nd-nd & nd-nd & nd-nd & nd-nd & nd-nd & nd-nd \\
\hline Netherlands & $1970-2003$ & $1970-2003$ & $1970-2003$ & $1987-2003$ & $1987-2003$ & $1987-2003$ & $1987-2003$ \\
\hline New Zealand & 1989-2002 & 1989-2002 & 1989-2002 & 1989-2002 & 1989-2002 & 1989-2002 & nd-nd \\
\hline Norway & $1970-2003$ & $1970-2003$ & $1970-2003$ & 1970-2003 & $1970-2003$ & $1970-2003$ & 1970-2002 \\
\hline Poland & 1992-2002 & $1992-2002$ & $1992-2002$ & $1992-2002$ & 1992-2002 & 1992-2002 & $1992-2002$ \\
\hline Portugal & 1977-1999 & 1972-1999 & 1977-1999 & 1980-1999 & 1980-1999 & 1980-1999 & 1980-1999 \\
\hline Slovak Republic & $1995-2003$ & $1995-2003$ & $1995-2003$ & $1995-2003$ & $1995-2003$ & $1995-2003$ & $1995-2003$ \\
\hline Spain & 1971-2002 & 1978-2002 & 1980-2002 & 1980-2002 & 1980-2002 & $1985-2002$ & $1985-2002$ \\
\hline Sweden & 1970-2002 & $1970-2002$ & $1970-2002$ & 1980-2002 & 1980-2002 & 1993-2001 & 1993-2001 \\
\hline Switzerland & nd-nd & nd-nd & nd-nd & nd-nd & nd-nd & nd-nd & nd-nd \\
\hline United Kingdom & 1970-2002 & 1971-2002 & $1971-2002$ & nd-nd & nd-nd & nd-nd & nd-nd \\
\hline United States & 1970-2001 & $1970-2001$ & $1970-2001$ & $1970-2001$ & $1970-2001$ & $1975-2001$ & $1975-2001$ \\
\hline
\end{tabular}

\section{B. Value added, current prices}

\begin{tabular}{|c|c|c|c|c|c|c|c|}
\hline & \multirow[t]{2}{*}{ Total } & \multirow[t]{2}{*}{ Manufacturing } & \multirow[t]{2}{*}{ Services } & \multicolumn{4}{|c|}{ Service sub-sectors } \\
\hline & & & & $\begin{array}{l}\text { Distributive } \\
\text { services }\end{array}$ & $\begin{array}{l}\text { Producer } \\
\text { services }\end{array}$ & Social services & $\begin{array}{l}\text { Personal } \\
\text { services }\end{array}$ \\
\hline Australia & $1970-2001$ & $1970-2001$ & $1970-2001$ & 1982-2001 & $1982-2001$ & $1982-2001$ & $1982-2001$ \\
\hline Austria & 1976-2002 & $1970-2002$ & 1976-2002 & 1976-2002 & 1976-2002 & 1976-2002 & 1976-2002 \\
\hline Belgium & 1970-2002 & 1970-2002 & $1970-2002$ & 1970-2002 & $1970-2002$ & $1970-2002$ & $1970-2002$ \\
\hline Canada & $1970-2000$ & $1970-2000$ & $1970-2000$ & $1970-2000$ & $1980-2000$ & $1970-2000$ & $1970-2000$ \\
\hline Czech Republic & $1990-2003$ & $1990-2003$ & $1990-2003$ & $1990-2003$ & $1990-2003$ & $1990-2003$ & $1995-2003$ \\
\hline Denmark & $1970-2002$ & $1970-2002$ & $1970-2002$ & 1970-2002 & 1970-2002 & 1970-2002 & $1970-2002$ \\
\hline Finland & $1970-2003$ & $1970-2003$ & $1970-2003$ & $1975-2003$ & $1975-2003$ & $1975-2003$ & $1975-2003$ \\
\hline France & $1970-2003$ & $1970-2003$ & $1970-2003$ & $1978-2003$ & $1978-2003$ & $1978-2003$ & $1978-2003$ \\
\hline Germany & $1991-2003$ & 1991-2003 & $1991-2003$ & 1991-2003 & 1991-2003 & $1991-2003$ & 1991-2003 \\
\hline Greece & 1970-2002 & 1970-2002 & 1970-2002 & 1995-2002 & 1995-2002 & 1995-2002 & 1995-2002 \\
\hline Hungary & 1991-2002 & 1991-2002 & 1991-2002 & 1991-2002 & 1991-2002 & 1991-2002 & nd-nd \\
\hline Italy & $1970-2003$ & $1970-2003$ & $1970-2003$ & $1970-2003$ & 1970-2003 & $1970-2003$ & $1970-2003$ \\
\hline Japan & 1970-2002 & 1970-2002 & 1970-2002 & nd-nd & 1980-2002 & 1980-1995 & nd-nd \\
\hline Korea & 1970-2001 & $1970-2001$ & $1970-2001$ & 1970-2001 & 1970-2001 & $1970-2001$ & 1970-2001 \\
\hline Luxembourg & $1985-2003$ & $1985-2003$ & $1985-2003$ & $1985-2003$ & $1985-2003$ & $1985-2003$ & $1985-2003$ \\
\hline Mexico & $1980-2002$ & $1970-2002$ & $1980-2002$ & 1988-2002 & 1988-2002 & $1988-2002$ & nd-nd \\
\hline Netherlands & $1970-2003$ & $1970-2003$ & $1970-2003$ & $1970-2003$ & $1970-2003$ & $1970-2003$ & $1970-2003$ \\
\hline New Zealand & 1971-1998 & 1971-1998 & 1971-1998 & 1986-1998 & 1986-1998 & 1986-1998 & 1986-1998 \\
\hline Norway & $1970-2003$ & $1970-2003$ & $1970-2003$ & $1970-2003$ & $1970-2003$ & $1970-2003$ & 1970-2002 \\
\hline Poland & 1991-2002 & 1992-2002 & $1992-2002$ & 1992-2002 & 1992-2002 & 1992-2002 & 1994-2002 \\
\hline Portugal & 1977-1999 & 1970-1999 & 1977-1999 & 1980-1999 & 1980-1999 & 1980-1999 & nd-nd \\
\hline Slovak Republic & $1993-2003$ & $1993-2003$ & $1993-2003$ & 1993-2003 & 1993-2003 & $1993-2003$ & 1993-2003 \\
\hline Spain & 1980-2002 & 1978-2002 & $1980-2002$ & 1980-2002 & 1980-2002 & $1980-2002$ & $1980-2002$ \\
\hline Sweden & $1970-2002$ & 1970-2002 & $1970-2002$ & 1980-2002 & 1980-2002 & 1993-2001 & 1993-2001 \\
\hline Switzerland & 1990-2002 & 1990-2002 & 1990-2002 & 1990-2002 & 1990-2002 & 1990-2002 & 1990-2002 \\
\hline United Kingdom & 1970-2002 & $1970-2002$ & $1970-2002$ & $1985-2002$ & $1985-2002$ & $1985-2002$ & 1989-2002 \\
\hline United States & 1970-2001 & 1970-2001 & $1970-2001$ & 1970-2001 & 1970-2001 & 1970-2001 & 1970-2001 \\
\hline
\end{tabular}


Table A1.2. data availability in the OECD STAN Database for Industrial Analysis (cont.)

C. Value added, constant prices

\begin{tabular}{|c|c|c|c|c|c|c|c|}
\hline \multirow[b]{3}{*}{ Australia } & \multirow[t]{2}{*}{ Total } & \multirow[t]{2}{*}{ Manufacturing } & \multirow[t]{2}{*}{ Services } & \multicolumn{4}{|c|}{ Service sub-sectors } \\
\hline & & & & $\begin{array}{c}\text { Distributive } \\
\text { services }\end{array}$ & $\begin{array}{c}\text { Producer } \\
\text { services }\end{array}$ & Social services & $\begin{array}{l}\text { Personal } \\
\text { services }\end{array}$ \\
\hline & $1974-2002$ & $1974-2002$ & $1974-2002$ & $1980-2002$ & $1980-2002$ & $1974-2002$ & $1980-2002$ \\
\hline Austria & 1976-2002 & 1976-2002 & 1976-2002 & 1976-2002 & 1976-2002 & 1976-2002 & 1976-2002 \\
\hline Belgium & 1970-2002 & 1970-2002 & $1970-2002$ & 1980-2002 & 1980-2002 & 1980-2002 & 1980-2002 \\
\hline Canada & 1970-2002 & 1970-2002 & $1970-2002$ & 1980-2002 & 1981-2002 & 1980-2002 & 1980-2002 \\
\hline Czech Republic & $1990-2003$ & $1990-2003$ & $1990-2003$ & $1995-2003$ & $1990-2003$ & $1995-2003$ & $1995-2003$ \\
\hline Denmark & 1970-2002 & $1970-2002$ & $1970-2002$ & 1970-2002 & 1970-2002 & $1970-2002$ & 1970-2002 \\
\hline Finland & $1970-2003$ & $1970-2003$ & $1970-2003$ & $1975-2003$ & $1975-2003$ & $1975-2003$ & $1975-2003$ \\
\hline France & $1978-2003$ & $1978-2003$ & $1978-2003$ & 1978-2003 & $1978-2003$ & $1978-2003$ & $1978-2003$ \\
\hline Germany & $1991-2003$ & $1991-2003$ & $1991-2003$ & 1991-2003 & $1991-2003$ & $1991-2003$ & $1991-2003$ \\
\hline Greece & 1970-2002 & 1970-2002 & $1970-2002$ & 1995-2002 & 1995-2002 & $1995-2002$ & $1995-2002$ \\
\hline Hungary & 1991-2002 & 1991-2002 & 1991-2002 & 1991-2002 & 1991-2002 & 1991-2002 & 1991-2002 \\
\hline Italy & $1970-2003$ & $1970-2003$ & $1970-2003$ & 1970-2003 & $1970-2003$ & $1970-2003$ & $1970-2003$ \\
\hline Japan & 1970-2002 & 1970-2002 & $1970-2002$ & nd-nd & 1980-2002 & $1980-1995$ & nd-nd \\
\hline Korea & $1970-2001$ & $1970-2001$ & $1970-2001$ & 1970-2001 & 1970-2001 & $1970-2001$ & 1970-2001 \\
\hline Luxembourg & $1985-2003$ & $1985-2003$ & $1985-2003$ & 1985-2003 & $1985-2003$ & $1985-2003$ & $1985-2003$ \\
\hline Mexico & 1980-2002 & 1980-2002 & $1988-2002$ & 1988-2002 & 1988-2002 & $1988-2002$ & nd-nd \\
\hline Netherlands & $1970-2003$ & $1970-2003$ & $1977-2003$ & 1977-2003 & 1986-2003 & $1980-2003$ & $1987-2003$ \\
\hline New Zealand & $1977-2001$ & $1977-2001$ & $1977-2001$ & 1987-2001 & $1987-2001$ & $1987-2001$ & $1987-2001$ \\
\hline Norway & $1970-2003$ & $1970-2003$ & $1970-2003$ & 1970-2003 & $1970-2003$ & $1970-2003$ & 1970-2002 \\
\hline Poland & 1992-2002 & 1992-2002 & 1992-2002 & 1992-2002 & 1992-2002 & $1992-2002$ & 1994-2002 \\
\hline Portugal & 1977-1999 & 1977-1999 & 1977-1999 & 1980-1999 & 1980-1999 & 1980-1999 & 1980-1999 \\
\hline Slovak Republic & $1993-2003$ & $1993-2003$ & $1993-2003$ & 1993-2003 & 1993-2003 & $1993-2003$ & $1993-2003$ \\
\hline Spain & 1980-2002 & 1980-2002 & 1980-2002 & 1980-2002 & 1980-2002 & 1980-2002 & 1980-2002 \\
\hline Sweden & 1980-2002 & 1980-2002 & $1980-2002$ & 1993-2002 & 1980-2002 & nd-nd & nd-nd \\
\hline Switzerland & 1990-2002 & 1990-2002 & $1990-2002$ & 1990-2002 & 1990-2002 & 1990-2002 & 1990-2002 \\
\hline United Kingdom & 1970-2002 & 1970-2002 & $1970-2002$ & 1973-2002 & 1978-2002 & $1970-2002$ & nd-nd \\
\hline United States & $1977-2001$ & $1977-2001$ & $1977-2001$ & 1977-2001 & 1977-2001 & $1977-2001$ & 1977-2001 \\
\hline
\end{tabular}


ECO/WKP(2005)14

Appendix 2 The rate of change in sectoral employment patterns ${ }^{1}$ Three-year moving averages, index 1981=1
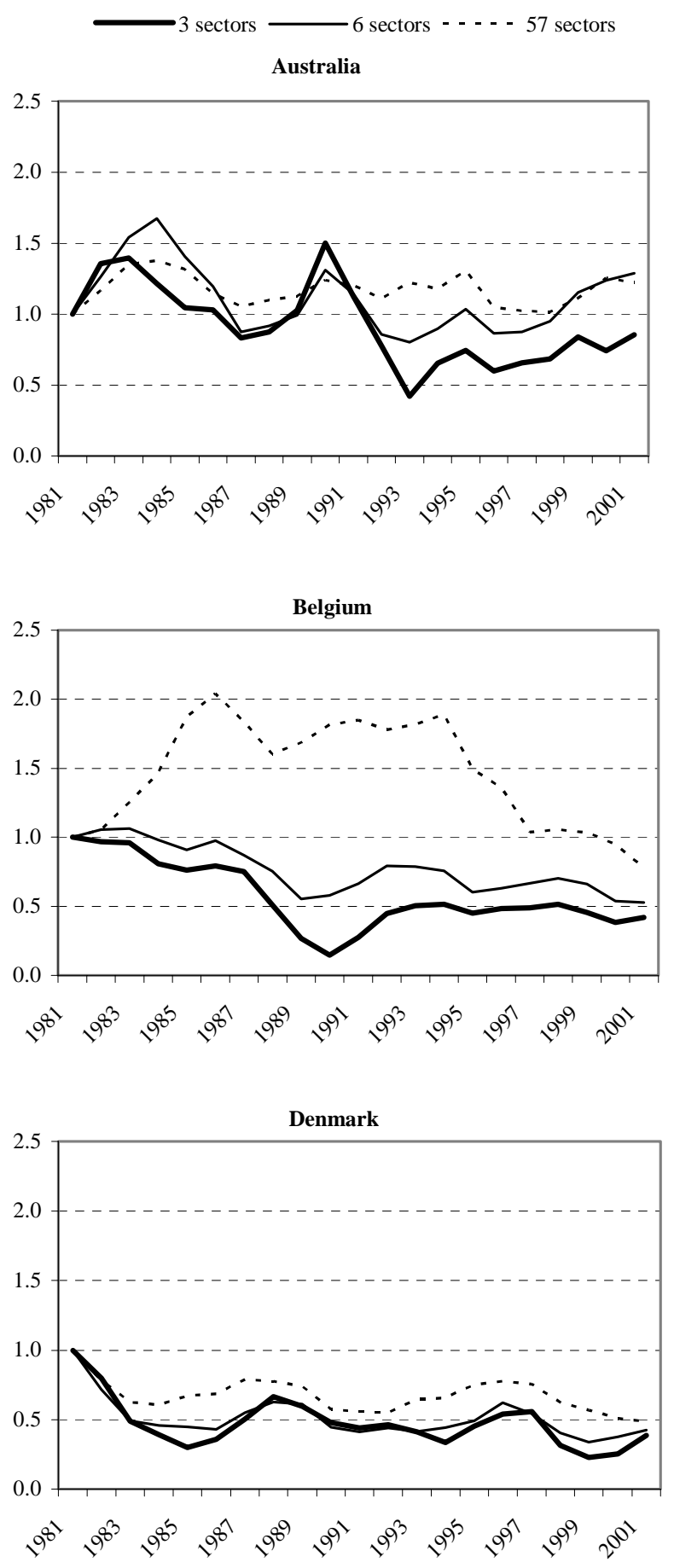
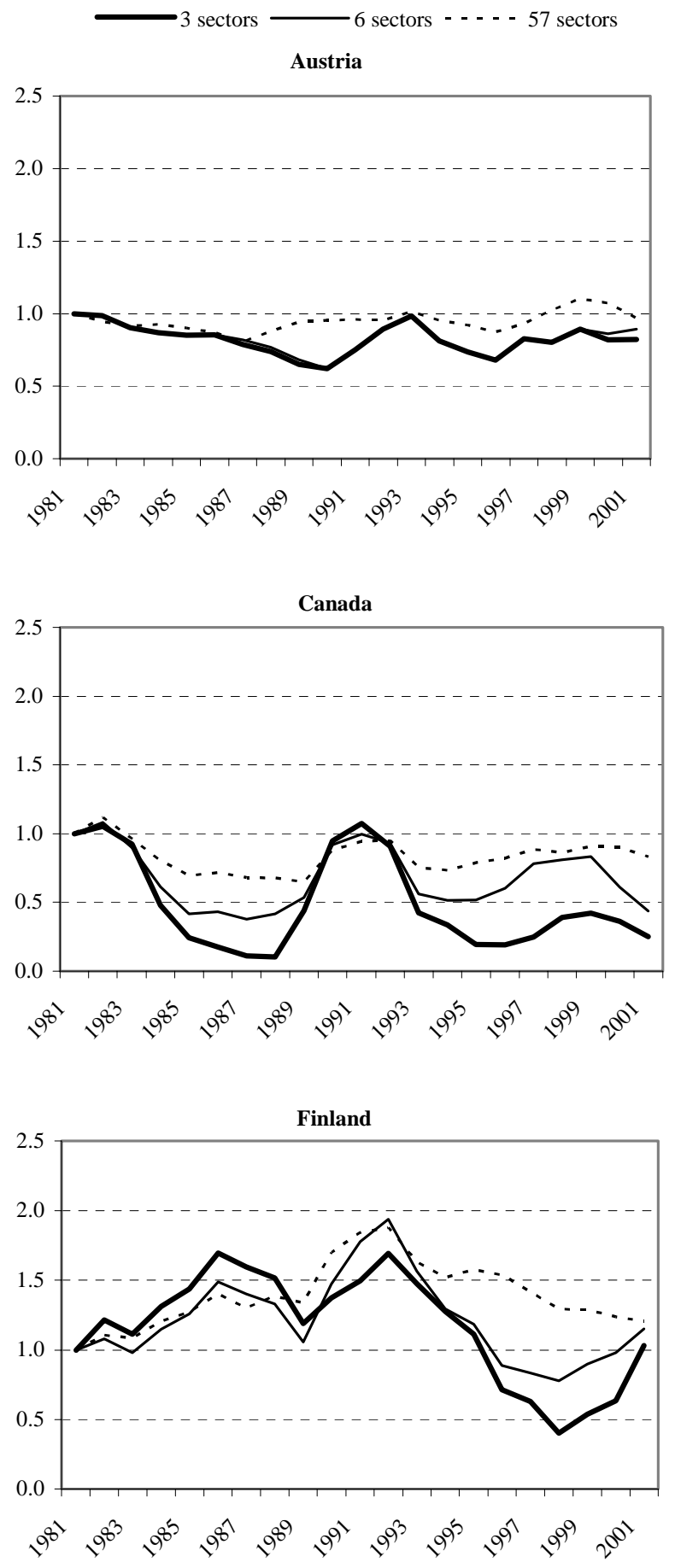

68 
Appendix 2 The rate of change in sectoral employment patterns ${ }^{1}$ (cont.)

Three-year moving averages, index 1981=1

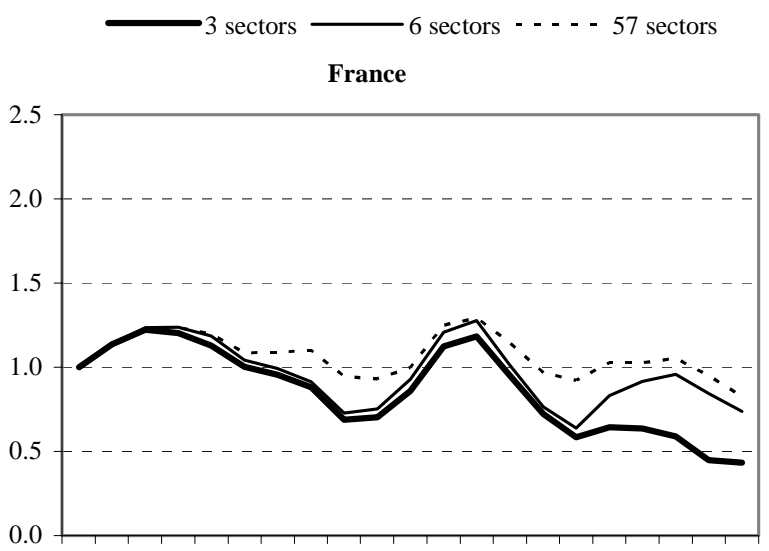

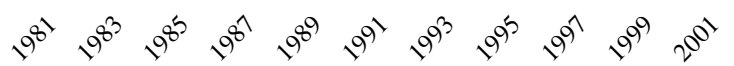

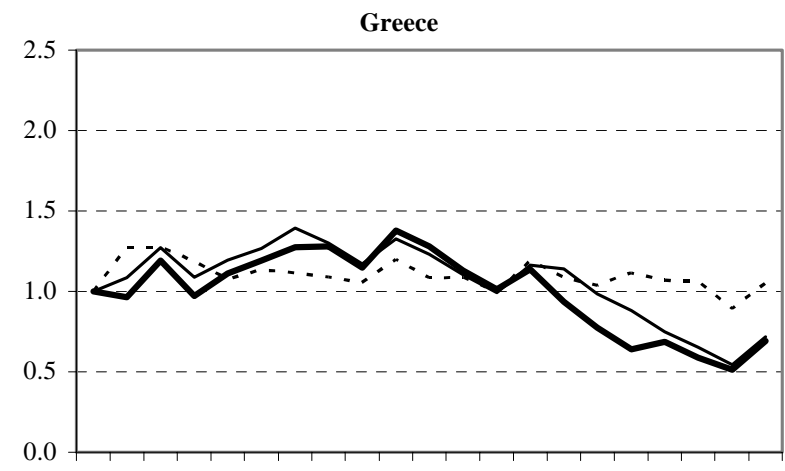

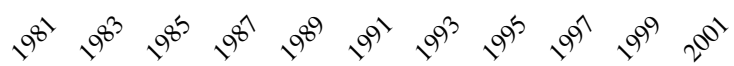

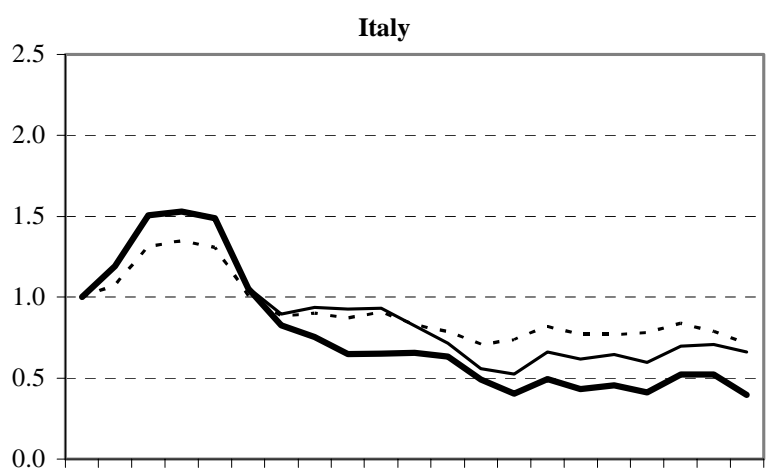

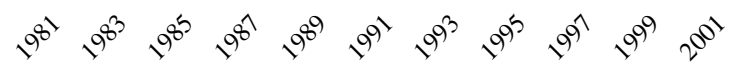
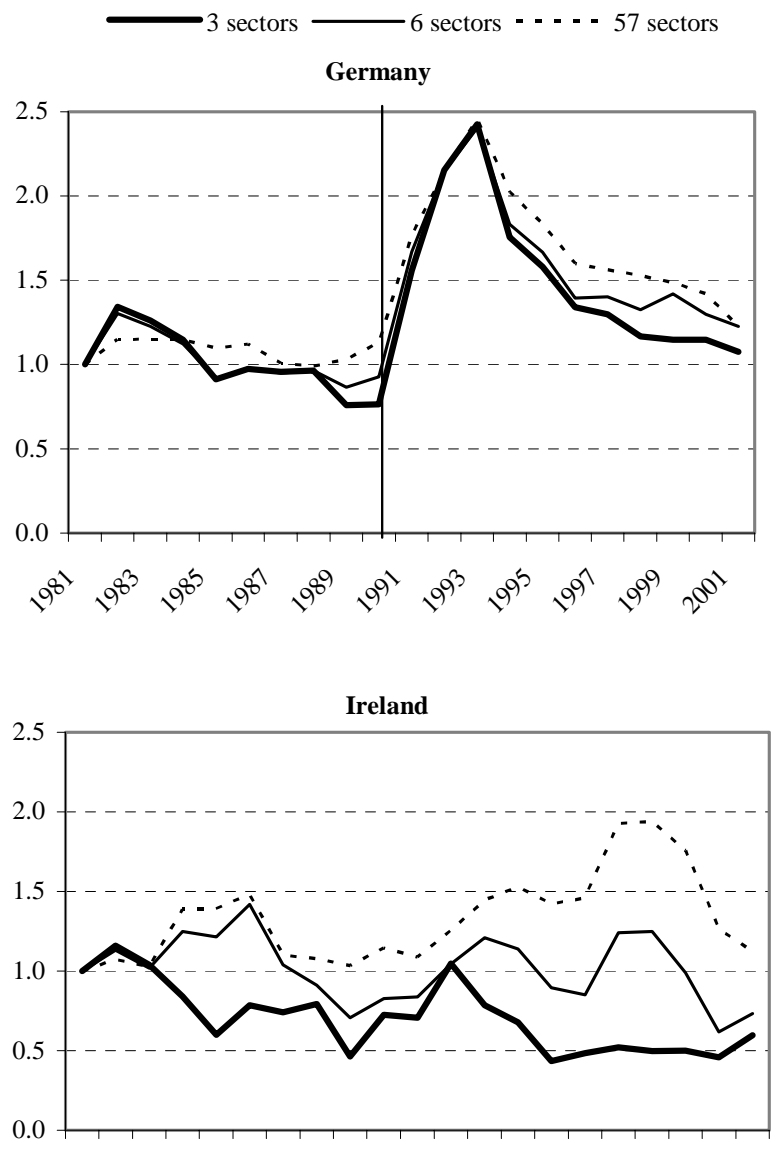

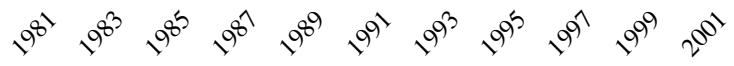

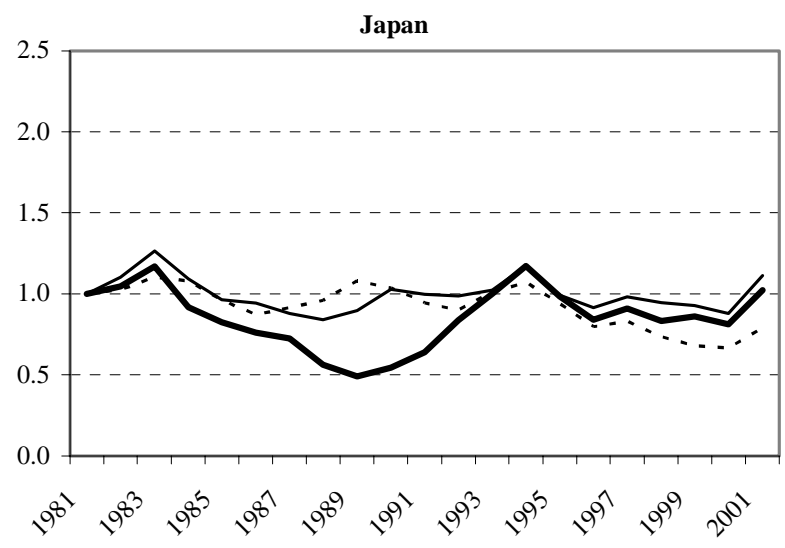


ECO/WKP(2005)14

Appendix 2 The rate of change in sectoral employment patterns ${ }^{1}$ (cont.)

Three-year moving averages, index 1981=1
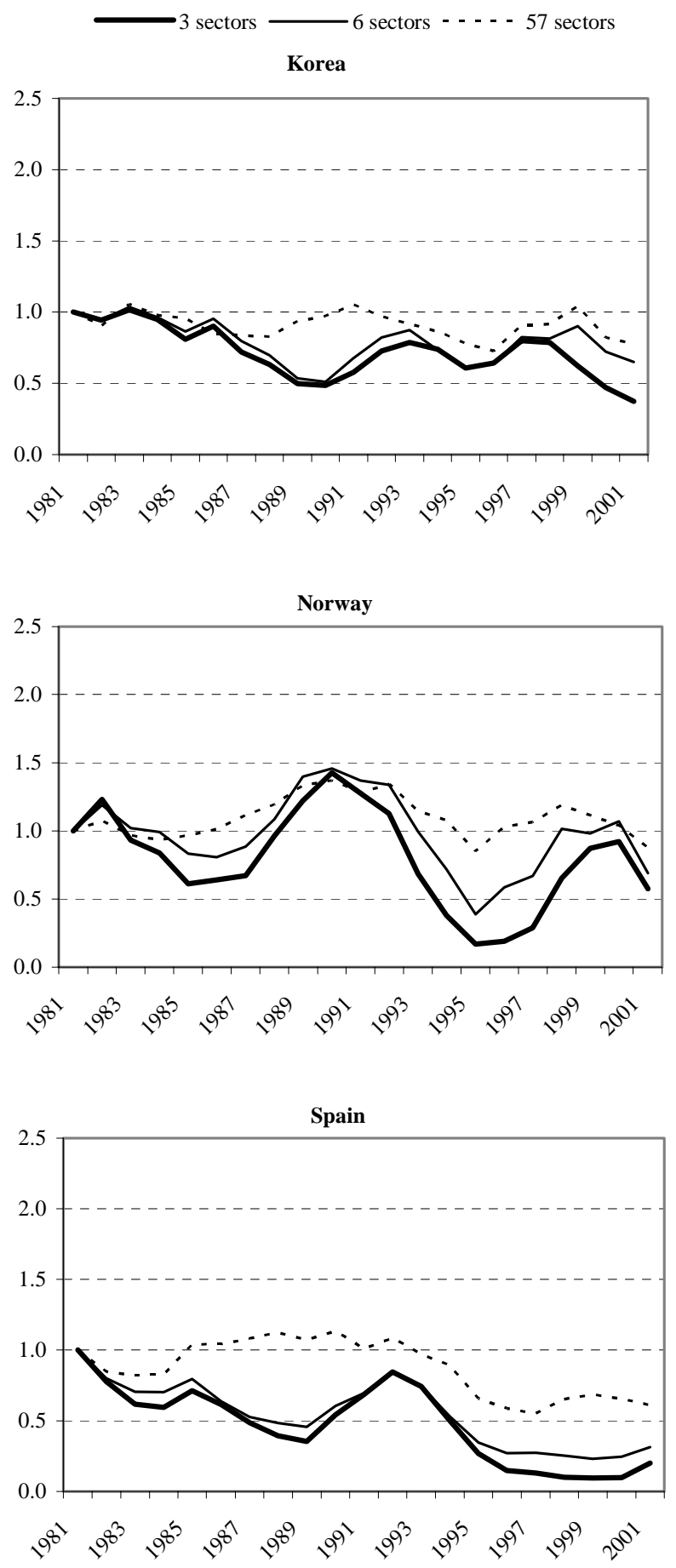

$$
-3 \text { sectors } \longrightarrow \text { sectors - . - } 57 \text { sectors }
$$

Netherlands
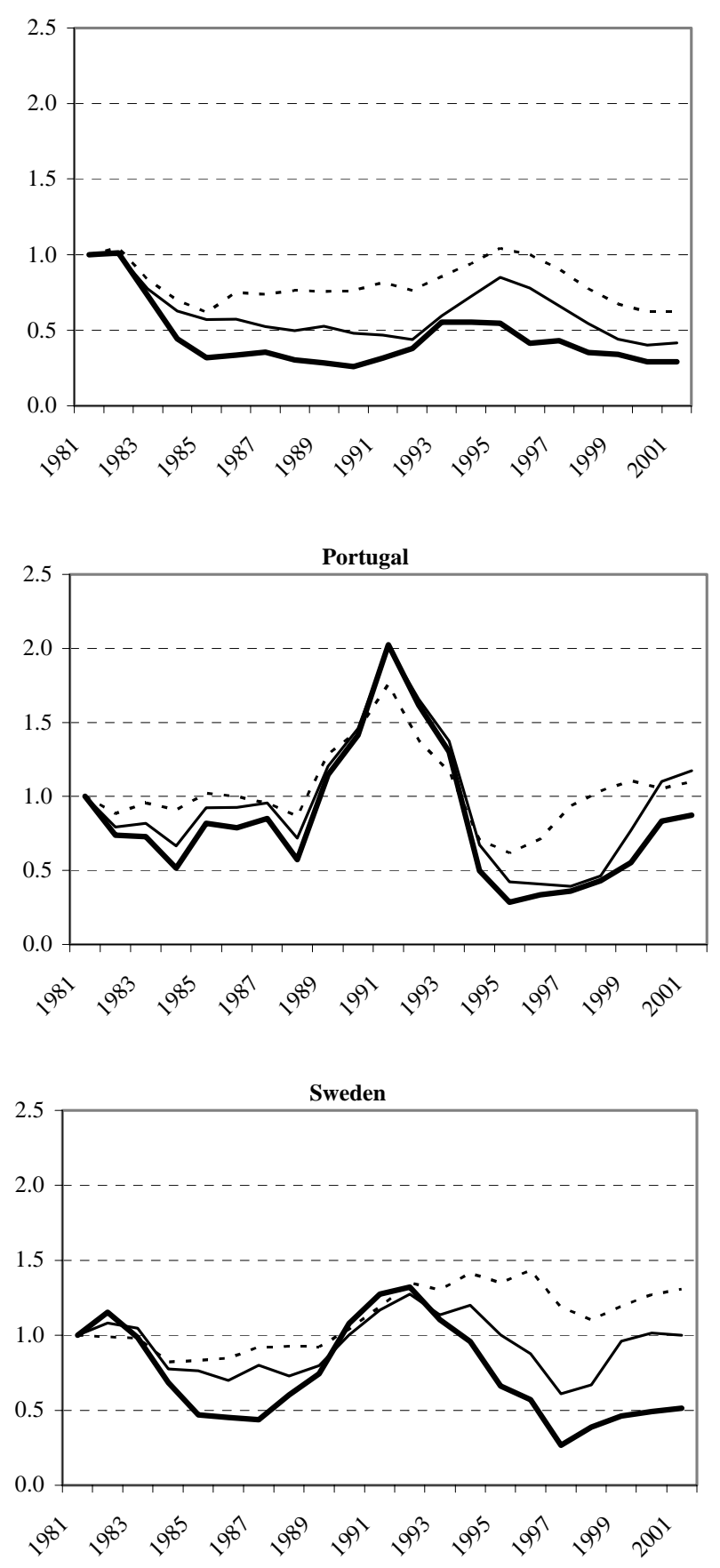

70 
Appendix 2 The rate of change in sectoral employment patterns ${ }^{1}$ (cont.)

Three-year moving averages, index 1981=1
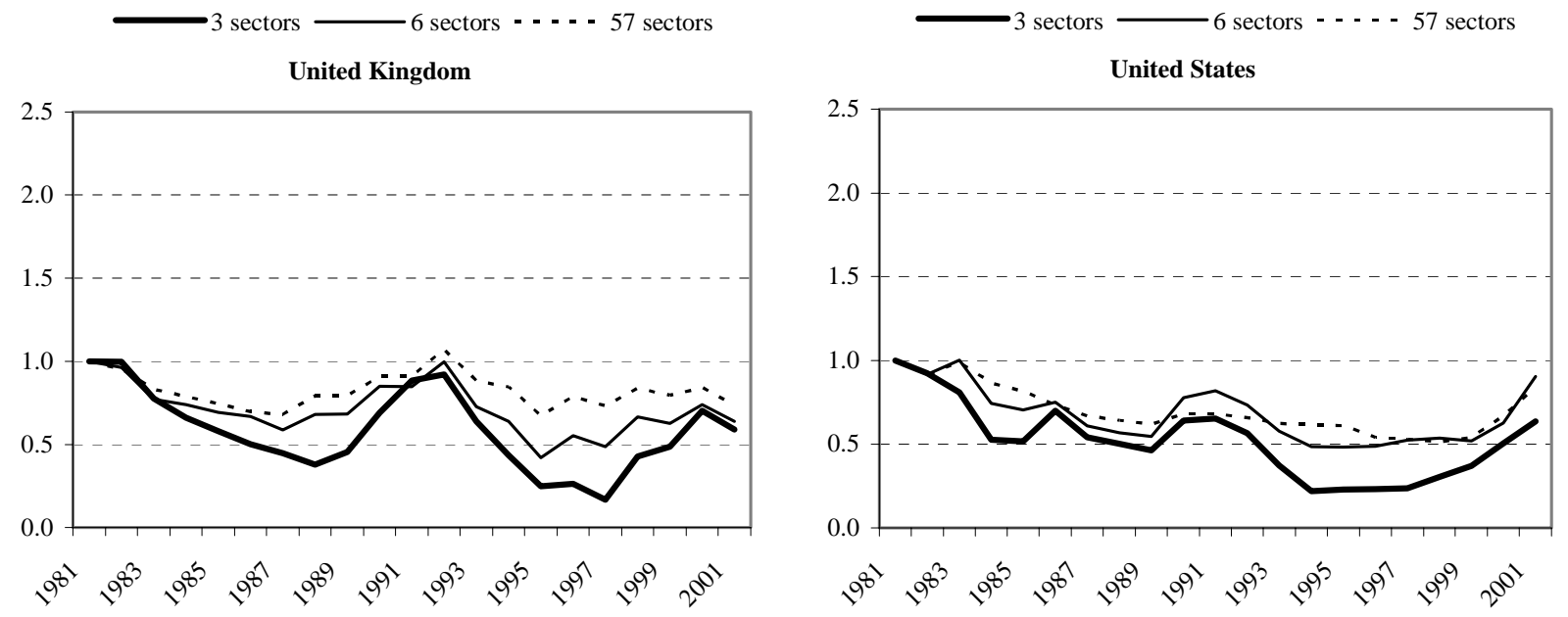

1. The rate of restructuring is calculated as: $0.5 \cdot \sum_{i}\left|N_{i, t}-N_{i, t-1}\right|$, where $\mathrm{N}_{\mathrm{i}, \mathrm{t}}$ denotes the share of sector $\mathrm{i}$ in total employment at time t. An unchanged employment pattern returns an indicator value of zero. The indicator is calculated for three sectors (primary, secondary and tertiary industries), six sectors (dividing services into producer, distributive, social and personal services) and 57 sectors.

Source: The OECD STAN Database for Industrial Analysis and Groningen Growth and Development Centre Database. 
Appendix 3 Gross labor flows between sectors

Per cent of total employment, average 2000-03 ${ }^{1}$

\section{Belgium}

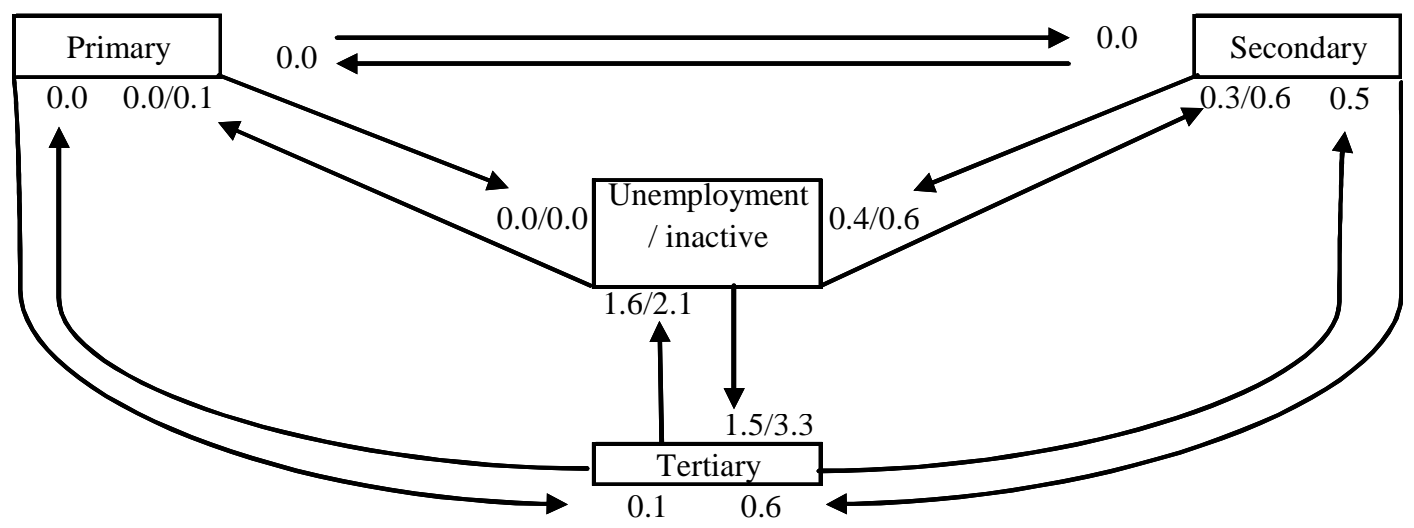

Czech Republic

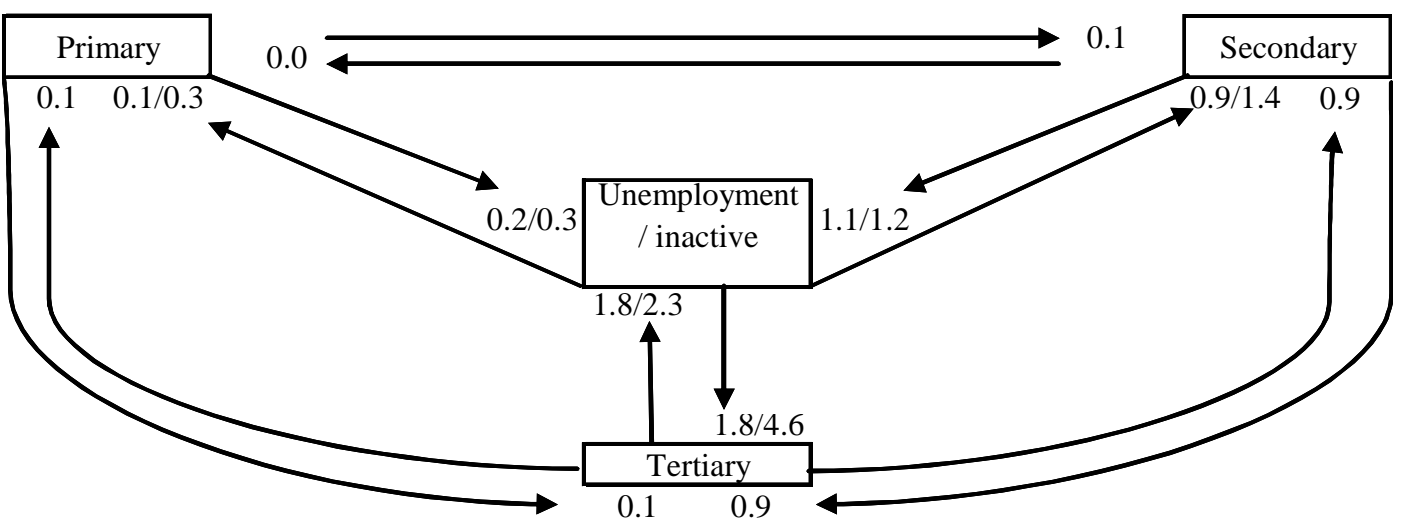

\section{Finland}

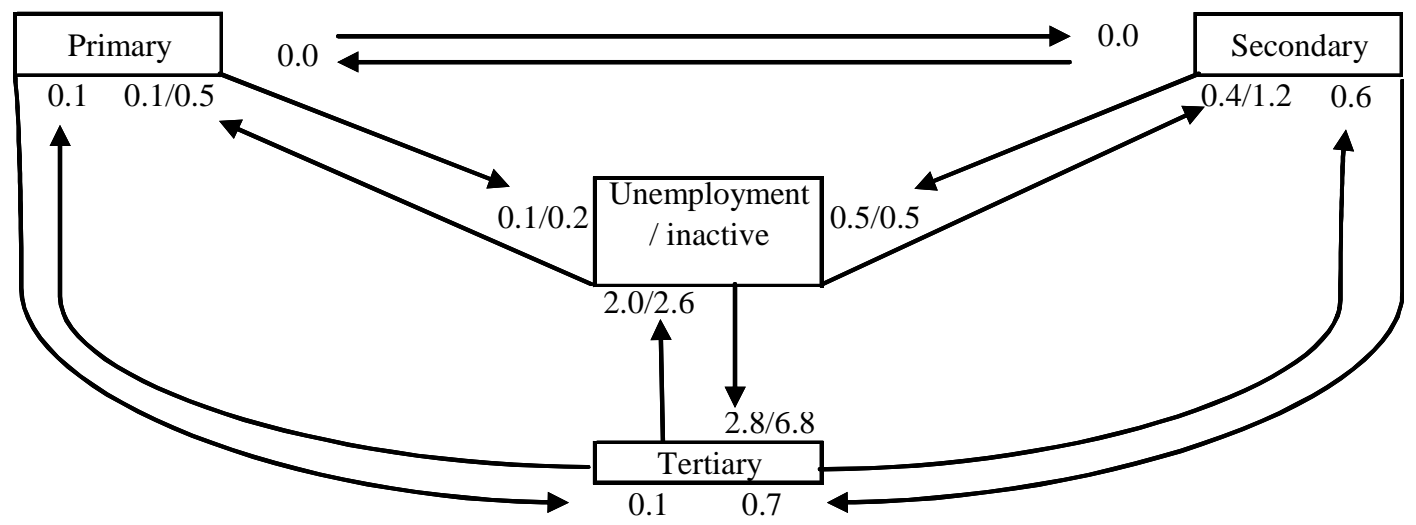




\section{Appendix 3 Gross labor flows between sectors (cont.)}

Per cent of total employment, average 2000-03 ${ }^{1}$

France

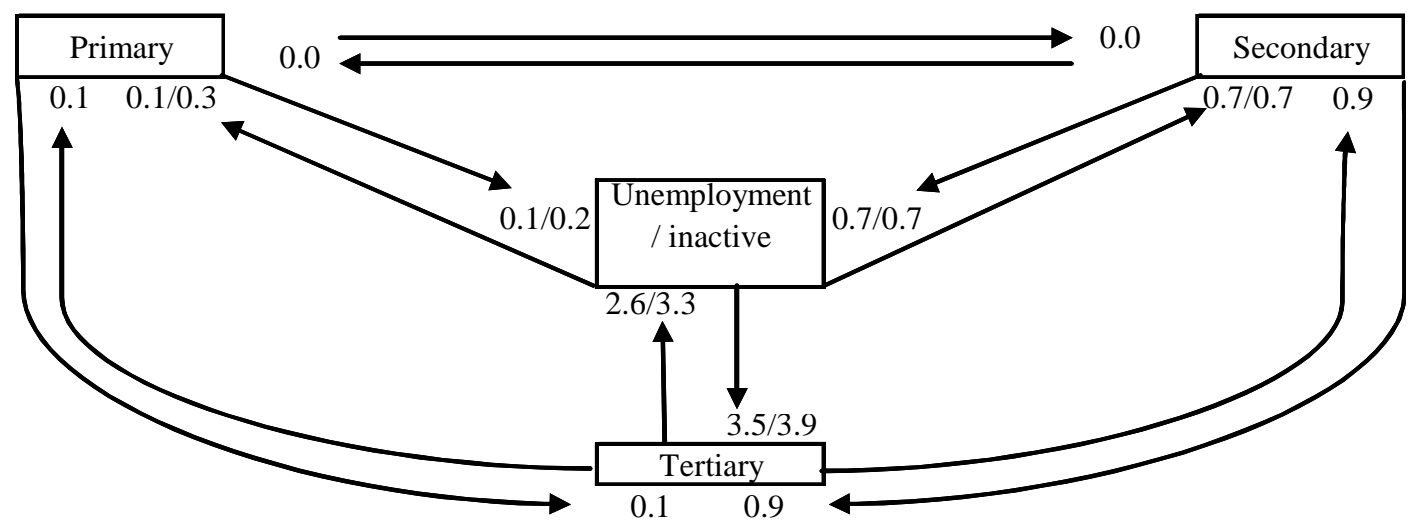

Germany

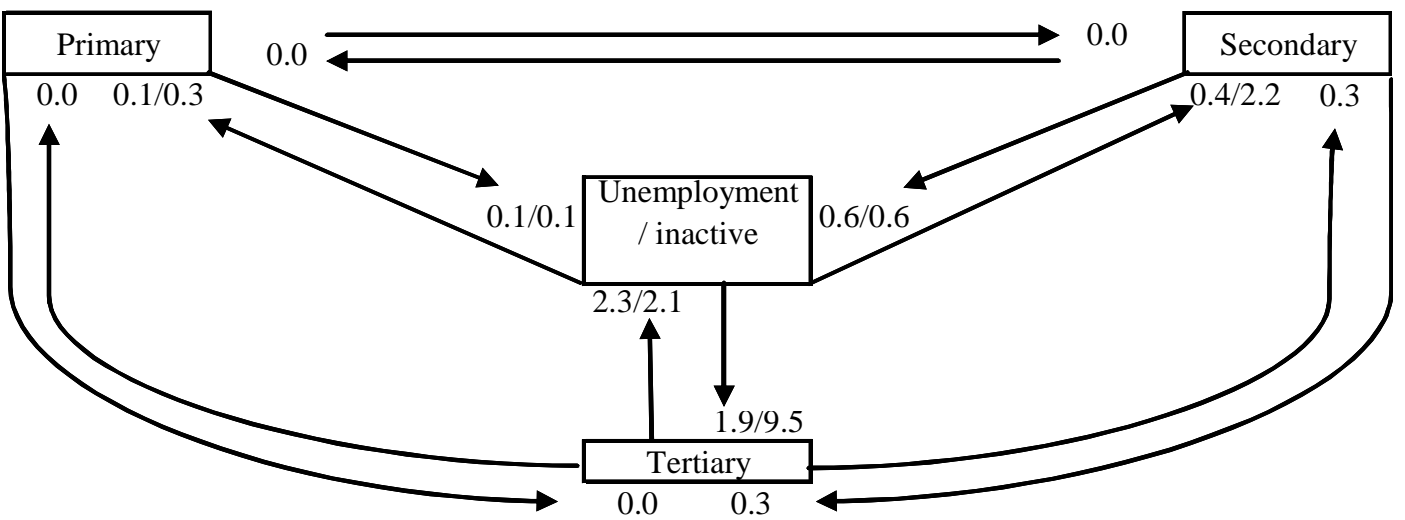

Greece

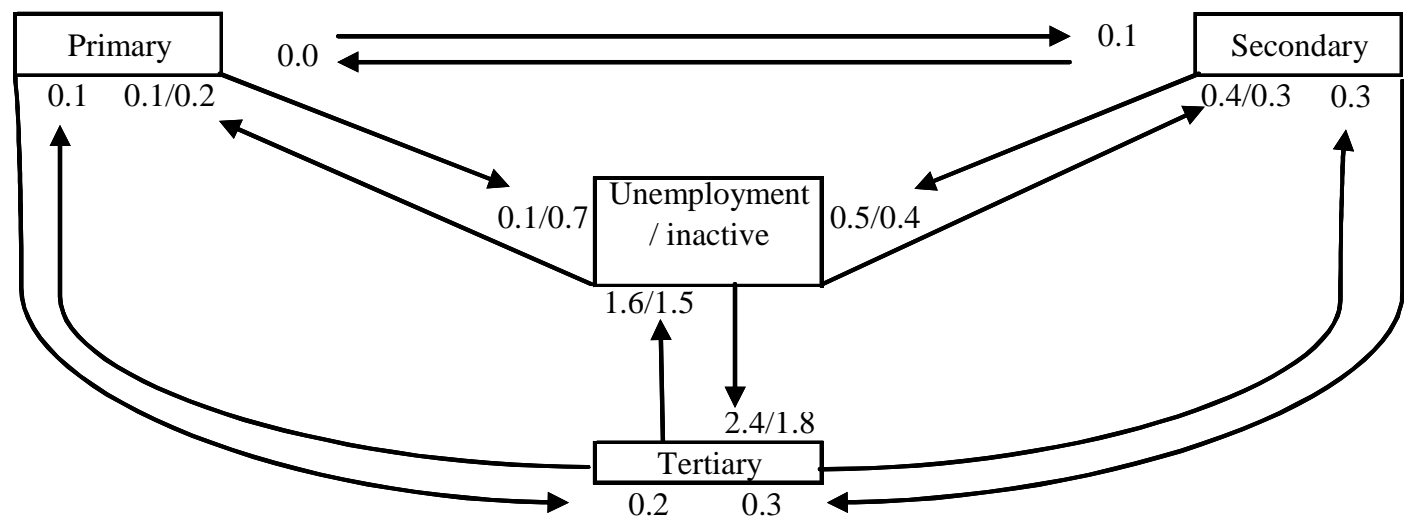


Appendix 3 Gross labor flows between sectors (cont.)

Per cent of total employment, average 2000-03 ${ }^{1}$

\section{Hungary}

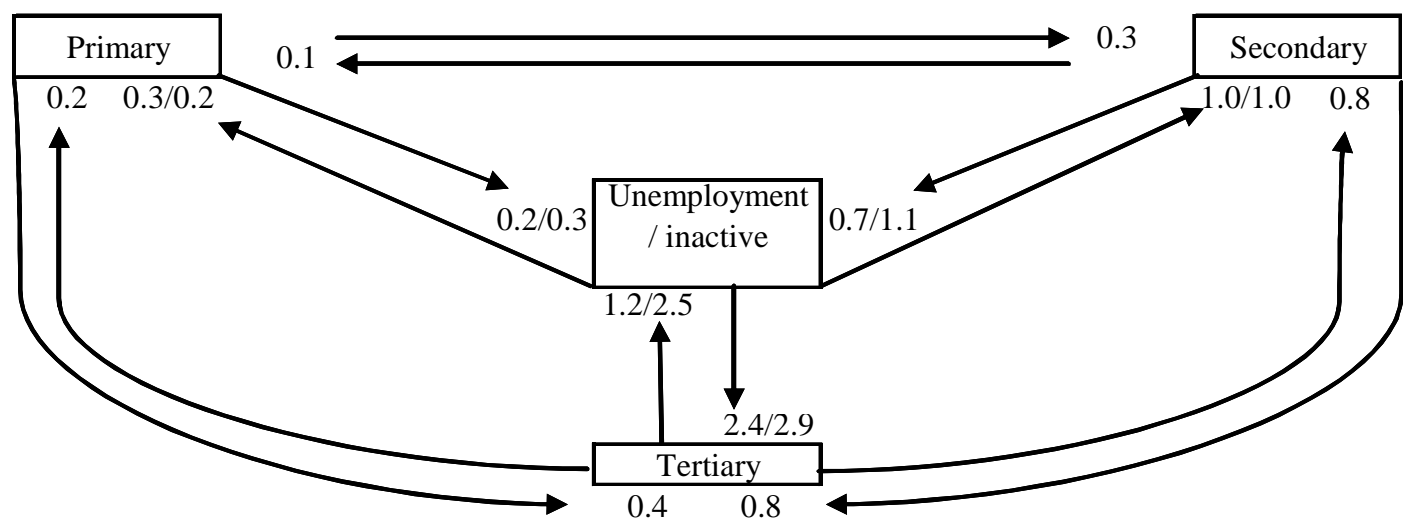

Italy

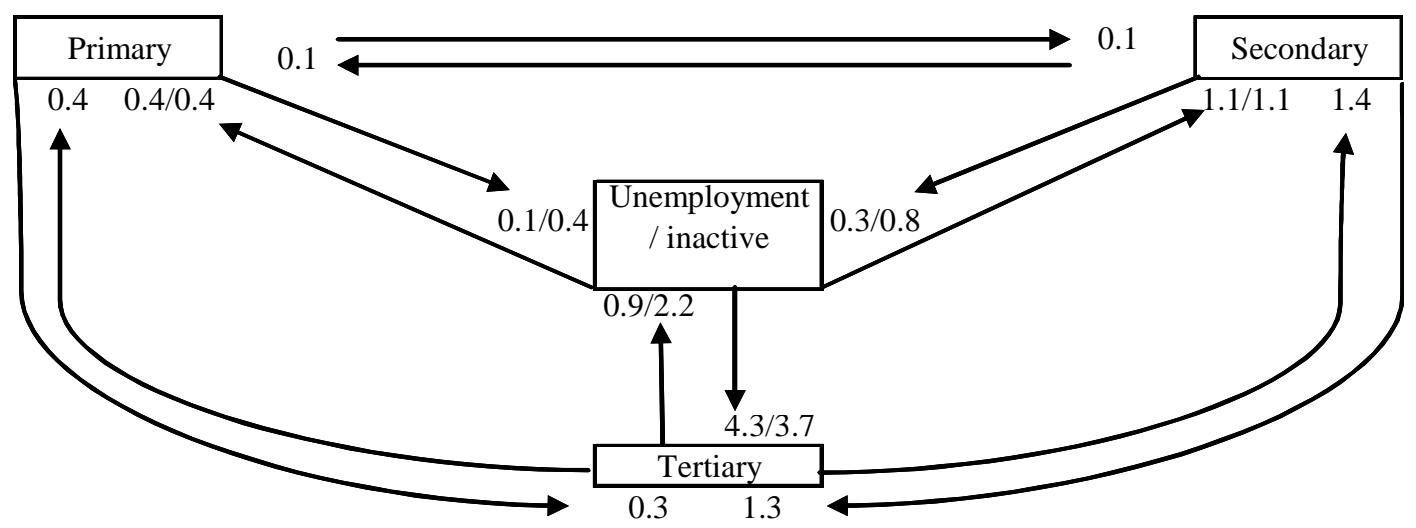

Portugal

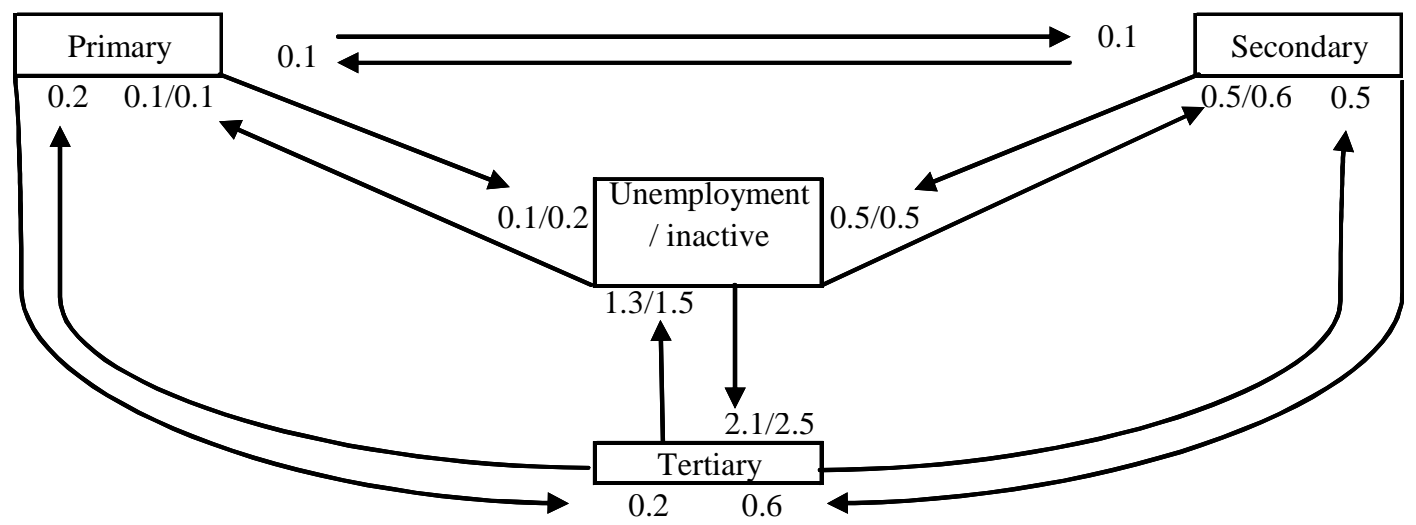




\section{Appendix 3 Gross labor flows between sectors (cont.)}

Per cent of total employment, average 2000-03 ${ }^{1}$

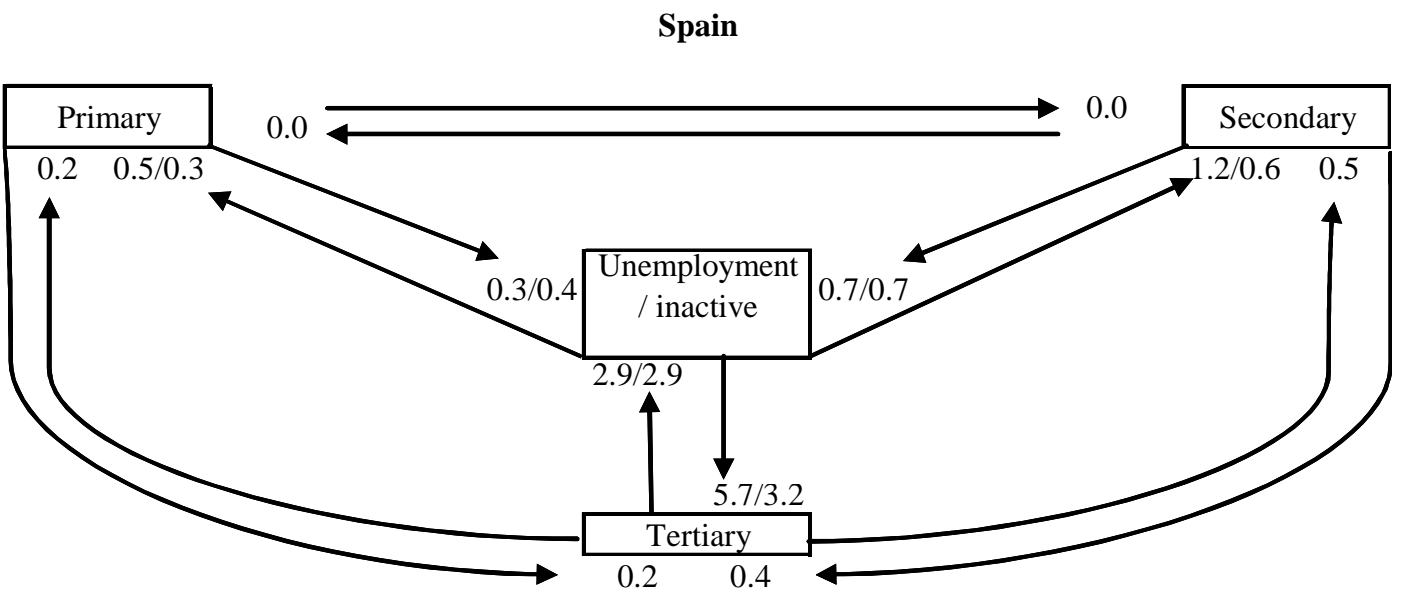

Slovak Republic

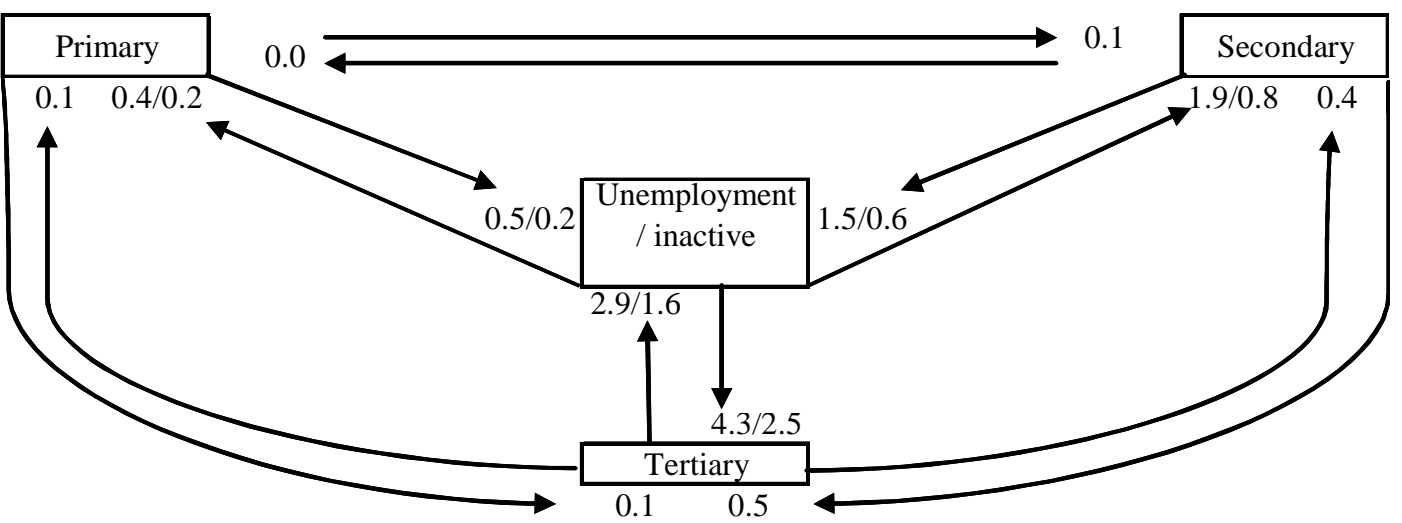

United kingdom

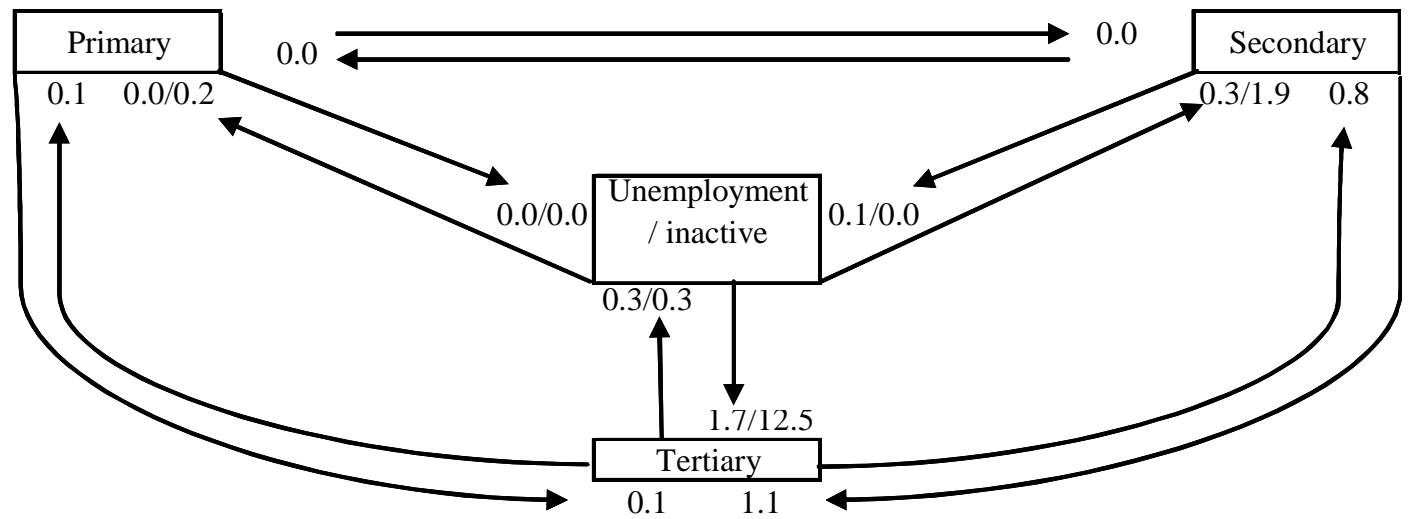

1. Defined as workers employed at the survey date and reported to have worked in a different sector one year earlier. Source: European Labour Force Survey. 


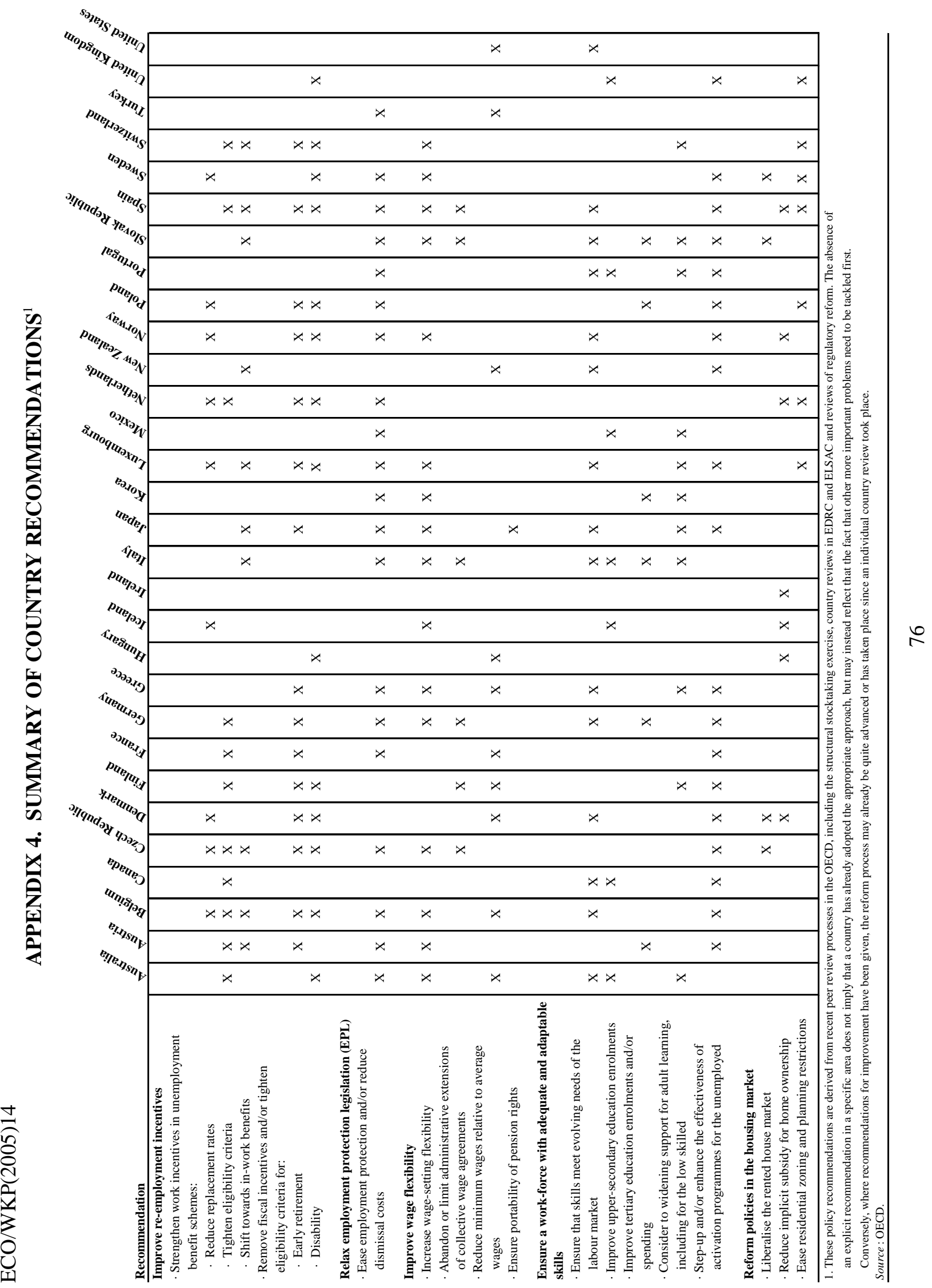




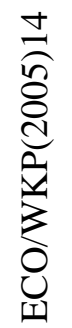

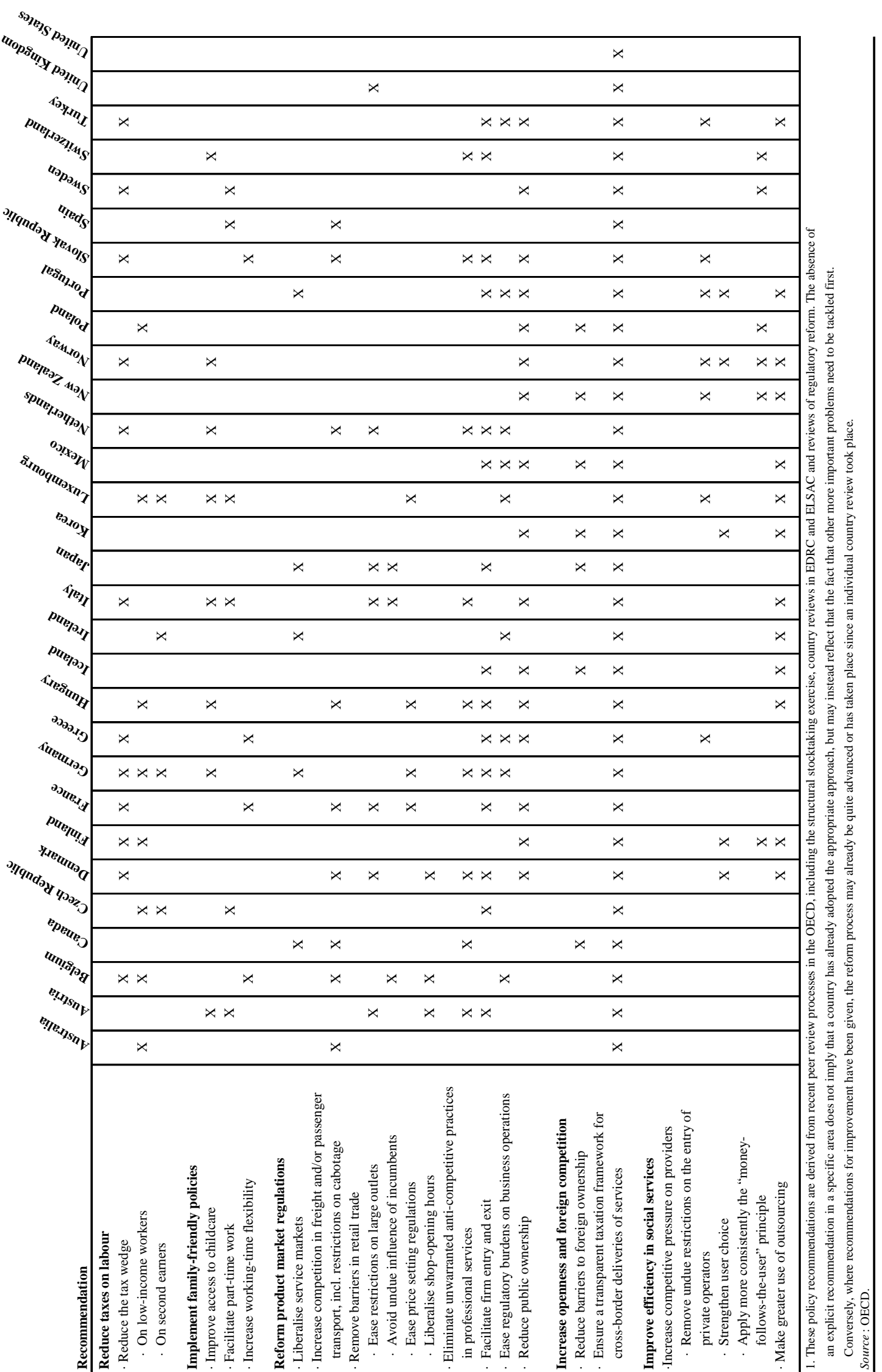

 


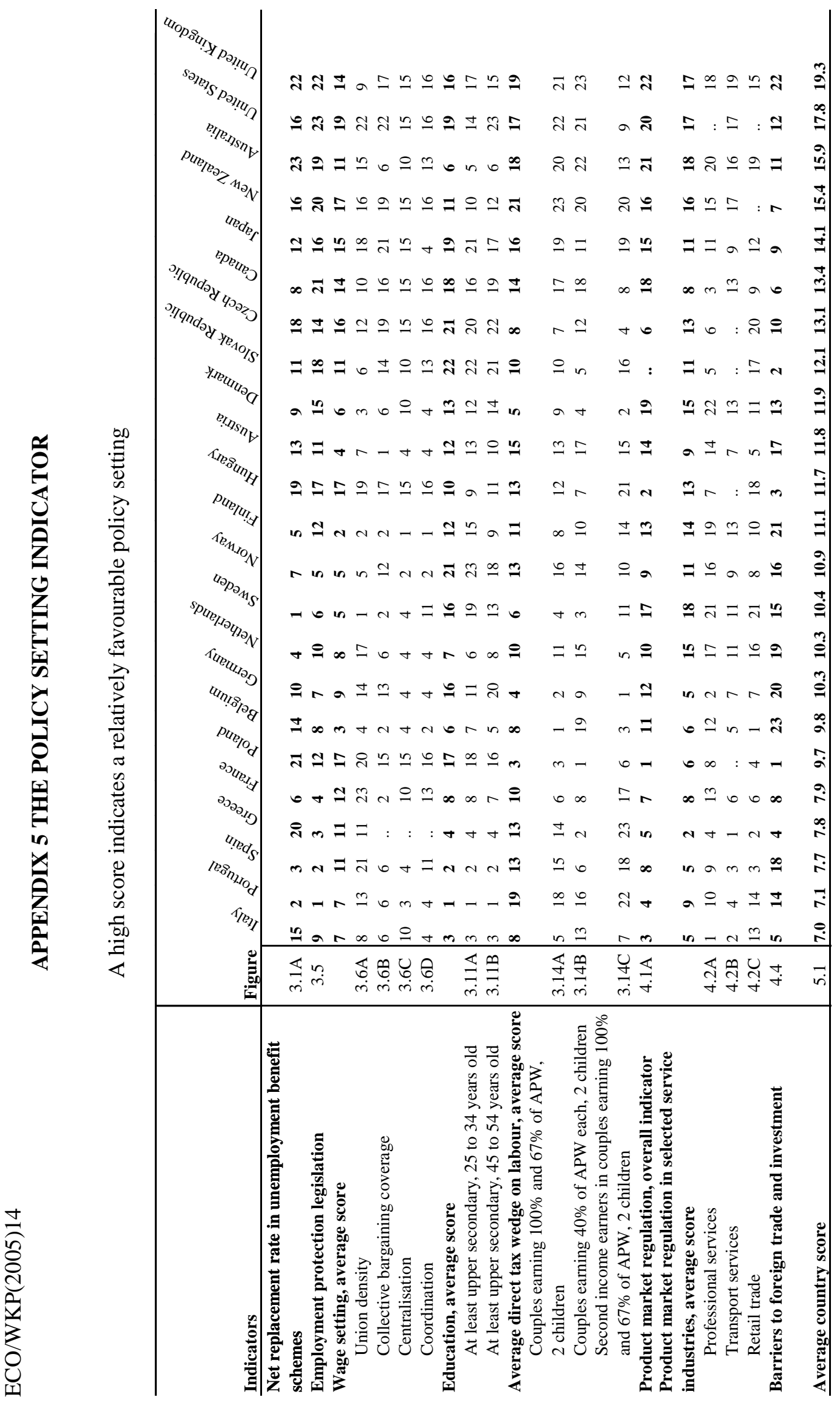


ECO/WKP(2005)14

\section{BIBLIOGRAPHY}

Abowd, J. and F. Kramarz (1997), "The Cost of Hiring and Separations", NBER Working Paper Series, No. 6110, Cambridge, Massachusetts, July.

Alesina, A., S. Ardagna, G. Nicoletti and F. Schiantarelli (2003), "Regulation and Investment", National Bureau of Economic Research Working Paper, No. 9560.

Amable, B. and D. Gatti (2004), "Product Market Competition, Job Security, and Aggregate Employment", Oxford Economic Papers, No. 56.

Amiti, M. and S.-J. Wei (2004), "Fear of Service Outsourcing: Is it Justified?", NBER Working Paper Series, No. 10808.

Barceló, C. (2003), "Housing Tenure and Labour Mobility: A Comparison across European Countries", CEMFI Working Paper, No. 0302, Madrid.

Bartelsman, E., S. Scarpetta and F. Schivardi (2003), "Comparative Analysis of Firm Demographics and Survival: Micro-level Evidence for the OECD Countries", OECD Economics Department Working Papers, No. 348, Paris.

Bassanini, A. and E. Ernst (2002), "Labour Market Institutions, Product Market Regulation, and Innovation: Cross-country Evidence", OECD Economics Department Working Papers, No. 316, Paris.

Baumol, W.J. (1967), "Macroeconomics of unbalanced growth: The anatomy of urban crisis", American Economic Review, Vol. 57.

Bertrand, M. and F. Kramarz (2002), "Does Entry Regulation Hinder Job Creation? Evidence from the French retail industry", The Quarterly Journal of Economics, Vol. 117, No. 4, November.

Blake D. and J.M Orszag (1997), "Portability and Preservation of Pension Rights in the UK", report of the Director-General's Inquiry into Pensions, Vol. 3, Office of Fair Trading.

Blanchard, O. and P. Portugal (2001), "What hides behind an unemployment rate: Comparing Portuguese and US unemployment", American Economic Review, Vol. 91, No. 1.

Blundell, R., and T. MaCurdy (1999), "Labor Supply: A Review of Alternative Approaches," in Orley Ashenfelter and David Card (eds.), Handbook of Labor Economics, Volume 3A, Amsterdam: Elsevier.

Boylaud, O. and G. Nicoletti (2001a), "Regulatory Reform in Retail Distribution", OECD Economic Studies, No. 32, Paris. 
Boylaud, O. and G. Nicoletti (2001b), "Regulatory Reform in Road Freight", OECD Economic Studies, No. 32, Paris.

Brandt, N., J.-M. Burniaux and R. Duval (2005), “Assessing the OECD Jobs Strategy: Past Developments and Reforms", OECD Economics Department Working Papers, forthcoming.

Brodersen, S. (2002), "Big Increase in Do-it-yourself Home Repairs and Improvements", The Rockwool Foundation Research Unit Newsletters, March.

Caballero, R.J., K. Cowan, E.M.R.A. Engel and A. Micco (2004), "Effective Labour Regulation and Microeconomic Flexibility", Massachusetts Institute of Technology (MIT), Department of Economics, Working Paper, No. 04-30.

Cahuc, P. and F. Kramarz (2004), "De la Précarité à la Mobilité: Vers une Sécurité Sociale Professionnelle", Rapport au Ministre de l'Economie, des Finances, et de l'Industrie et au Ministre de l'Emploi, du Travail et de la Cohésion Sociale, 2004.

Calmfors, L. and J. Driffill (1988), "Bargaining Structure, Corporatism and Macroeconomic Performance", Economic Policy, Vol. 6.

Centraal Planbureau (1995), "Economic Effecten van Liberalisering van Winkeltijden in Nederland" (The Economic Effects of Liberalised Shop Opening Hours in the Netherlands), Working Paper, No. 74, The Hague.

Conway, P., V. Janod and G. Nicoletti (2005), "Product Market Regulation in OECD Countries, 19982003”, OECD Economics Department Working Papers, No. 419, Paris.

Copenhagen Economics (2005), "Economic Assessment of the Barriers to the Internal Market for Services", final report, January. www.copenhageneconomics.com

Del Boca, A. and P. Rota (1998), "How Much Does Hiring and Firing Cost? Survey Evidence from a Sample of Italian Firms", Labour: Review of Labour Economics and Industrial Relations, Vol. 12 (3).

Department of Trade and Industry (2004), "The Service Sector in the UK and France: Addressing Barriers to the Growth of Output and Employment", An Anglo-French Report prepared by the French Ministère de l'Économie Des Finances et de l'Industrie and the UK Department of Trade and Industry.

Duval, R. (2003), "The Retirement Effects of Old-age Pension and Early Retirement Schemes in OECD Countries", OECD Economics Department Working Papers, No. 370, Paris.

ECB (2003), "Structural Factors in the EU Housing Markets”, European Central Bank, March.

European Commission (2000), "European Competitiveness Report 2000", Commission Staff Working Paper.

Farber, H.S. (2003), "Job Loss in the United States, 1981-2001", National Bureau of Economic Research, NBER Working Paper Series, No. 9707, May.

Freeman, R.B. and R. Schettkat (2002), "Marketization of Production and the US-Europe Employment Gap", National Bureau of Economic Research Working paper, No. 8797. 
Friedman, E., S. Johnson, D. Kaufmann and P. Zoido-Lobaton (2000), "Dodging the Grabbing Hand: The Determinants of Unofficial Activity in 69 Countries", Journal of Public Economics, Vol. 76.

Fuchs, V.R. (1968), The Service Economy, New York and London: Colombia University Press.

Giorno, C., M. Jimenez and P. Gugler (2004), "Product Market Competition and Economic Performance in Switzerland", OECD Economics Department Working Papers, No. 383.

Global Insight (2004), "The Comprehensive Impact of Offshore IT Software and Services Outsourcing on the U.S. Economy and the IT Industry".

Golub, S.S. (2003), "Measures of Restrictions on Inward Foreign Direct Investment for OECD Countries", OECD Economic Studies, No. 36.

Gómez-Salvador, R., J. Messina and G. Vallanti (2004), "Gross Job Flows and Institutions in Europe", European Central Bank, Working Paper Series, No. 318, March.

Gönenç, R. and G. Nicoletti (2001), "Regulation, Market Structure and Performance in Air Passenger Transportation", OECD Economic Studies, No. 32, Paris.

Gönenç, R., M. Maher and G. Nicoletti (2001), "The Implementation and the Effects of Regulatory Reform: Past Experience and Current Issues", OECD Economic Studies, No. 32, Paris.

Gordon, R.J. (2004), "Why was Europe Left at the Station When America's Productivity Locomotive Departed?", NBER Working Paper Series, No. 10661, Cambridge, Massachusetts, July.

Greenaway, D., R. Upward, and P. Wright (2000), "Sectoral Transformation and Labour Market Flows", Oxford Review of Economic Policy, Vol. 16, No. 3.

Grubb, D. (2003), "Points of Comparison Between Australia's Job Network and the Dutch Market for Reintegration Services", Australian Journal of Labour Economics, Vol. 6, No. 2, June.

Høj, J. and M. Wise (2004), "Product Market Competition and Economic Performance in Japan", OECD Economics Department Working Papers, No. 387, Paris.

Housing Statistics in the European Union (2003), National Agency for Enterprise and Housing, Denmark.

Huber, P. (2004), "Inter-Regional Mobility in Europe: A Note on the Cross-Country Evidence", Austrian Institute for Economic Research, Applied Economics Letters, No. 11.

ILO (2001), World Employment Report 2001, International Labour Organization.

Jacobson, L.S., R.J. LaLonde and D.N. Sullivan (1993), "Earning Losses of Displaced Workers", The American Economic Review, Vol. 83, No. 4, September.

Jaumotte, F. (2003), "Female Labour Force Participation: Past Trends and Main Determinants in OECD Countries", OECD Economics Department Working Papers, No. 376, Paris.

Jean, S. and G. Nicoletti (2002), "Product Market Regulation and Wage Premia in Europe and North America: An Empirical Investigation", OECD Economics Department Working Papers, No. 318, Paris. 


\section{ECO/WKP(2005)14}

Joumard, I., P.M. Kongsrud, Y.-S. Nam and R. Price (2003), "Enhancing the Effectiveness of Public Spending: Experience in OECD Countries", OECD Economic Studies, No. 37, Paris.

Klapper, L., L. Laeven and R. Rajan (2004), "Business Environment and Firm Entry: Evidence from International Data", NBER Working Paper, No. 10380, Cambridge (Massachusetts).

Kletzer, L.G. (1989), "Returns to Seniority after Permanent Job Loss", The American Economic Review, Vol. 79, No. 3, June.

Kletzer, L.G. (2001), "Job Loss from Imports: Measuring the Costs", The Globalisation Balance Sheet Series, Institute for International Economics.

Kox, H. (2004), "The Effects of Policy Heterogeneity on Trade and Investment in Services: Empirical Analysis for the EU", Paper presented to the OECD Working Party on Statistics, Special Session on Globalisation, 18-19 November, Paris,.

Kuhn, P. J. (2002), "Losing Work, Moving on: International Perspectives on Worker Displacement" (ed.), Upjohn Institute for Employment Research.

Lefranc, A. (2003), "Labour Market Dynamics and Wage Losses of Displaced Workers in France and the United States", William Davidson Institute Working Paper, No. 614, September.

Lundsgaard, J. (2002), "Competition and Efficiency in Publicly Funded Services", OECD Economics Studies, No. 35, Paris.

Mann, C.L. (2003), "Globalization of IT Services and White Collar Jobs: The Next Wave of Productivity Growth", Institute for International Economics, International Economics Policy Briefs, December.

Martin, J.P. and D. Grubb (2001), "What Works and for Whom: A Review of OECD Countries Experiences with Active Labour Market Policies", Swedish Economic Policy Review, Vol. 8, No. 2.

McCarthy, J.C. (2002), “3.3 Million U.S. Services Jobs to go Offshore”, Forrester Research, Trends, November 11.

McCarthy, J.C. (2004), "Near-Term Growth of Offshoring Accelerating”, Forrester Research, Trends, May 14.

Messina, J. (2004), "Institutions and Service Employment: A Panel Study for OECD Countries", ECB Working Paper Series, No. 320, March.

Nickell, S., S. Redding and J. Swaffield (2004), "The Uneven Pace of Deindustrialisation in the OECD", paper prepared for OECD Workshop on Services, 15-16 November, Paris.

Nicoletti, G. and S. Scarpetta (2003), "Regulation, Productivity and Growth: OECD Evidence”, Economic Policy, April, Paris.

Nicoletti, G., S. Scarpetta and O. Boylaud (2003), "Summary Indicators of Product Market Regulation with an Extension to Employment Protection Legislation", OECD Economics Department Working Papers, No. 226, Paris.

OECD (1997), Implementing the OECD Jobs Strategy: Member Countries' Experiences, Paris. 
OECD (2000a), "Disparities in Regional Labour Markets”, OECD Employment Outlook 2000, Paris.

OECD (2000b), “Eligibility Criteria for Unemployment Benefits”, OECD Employment Outlook, Paris.

OECD (2000c), "Employment in the Service Economy: A Reassessment”, OECD Employment Outlook, Paris.

OECD (2002a), OECD Economic Surveys: Sweden, Paris.

OECD (2002b), "And the Twain Shall Meet: Cross-Market Effects of Labour and Product Market Policies", OECD Employment Outlook, Paris.

OECD (2003), “Making Work Pay - Making Work Possible”, OECD Employment Outlook, Paris.

OECD (2004a), "Employment Protection Regulation and Labour Market Performance", OECD Employment Outlook, Paris.

OECD (2004b), OECD Economic Surveys: Japan, February, Paris.

OECD (2004c), "Wage Setting Institutions and Outcomes", OECD Employment Outlook, Paris.

OECD (2004d), "Improving Skills for More and Better Jobs: Does Training Make a Difference”, OECD Employment Outlook, Paris.

OECD (2004e), "Informal Employment and Promoting the Transition to a Salaried Economy", OECD Employment Outlook, Paris.

OECD (2004f), Taxing Wages 2002-2003, Paris.

OECD (2004g), OECD Economic Surveys: Netherlands, Paris.

OECD (2004h), "The Application of Consumption Taxes to the Trade in International Services and Intangibles", http://www.oecd.org/dataoecd/56/36/32997184.pdf, Paris.

OECD (2004i), OECD Economic Surveys: Finland, Paris.

OECD (2005a), Trade and Structural Adjustment, Forthcoming, Paris.

OECD (2005b), “Consumption Tax Trends: VAT/GST”, Excise and Environmental Taxes, Paris.

OECD (2005c), "Structural Reform in the Rail Industry: Should Train Operations be Separated from the Provision of the Track Infrastructure?", OECD Roundtable, forthcoming.

Oswald, J.A. (1999), “The Housing Market and Europe's Unemployment: A Non-Technical Paper”.

Parker, A. (2004), “Two-Speed Europe: Why 1 million Jobs Will Move Offshore”, Forrester Research, Trends, August.

Paterson, I., M. Fink and A. Ogus (2003), "Economic Impact of Regulation in the Field of Liberal Professions in Different Member States", Institute for Advanced Studies, Vienna, Study for the European Commission. 
Røed, K. and T. Zhang (2000), "Does Unemployment Compensation Affect Unemployment Duration?", The Economic Journal, Vol. 113.

Rowthorn, R. and J.R. Wells (1987), "De-Industrialization and Foreign Trade", Cambridge: CUP.

Rupert, P. (1994), "Estimating Substitution Elasticities in Household Production Models", Research Department Staff Report, No. 186, Federal Reserve Bank of Minneapolis, December.

Russo, G. and R. Schettkat (2001), "Structural Economic Dynamics: Myth or Reality? Structural Change and the Final Product Concept", in Ten Raa and Schettkat (eds.), The Growth of Service Industries: The Paradox of Exploding Costs and Persistent Demand, Cheltenham: Edward Elgar.

Schettkat, R. and L. Yocarini (2003), "The Shift to Services: A Review of the Literature", Institute for the Study of Labour, IZA DP No. 964.

Strandell, A.-C. (2004), "Multinational Enterprises in Sweden: Impact on Employment, Productivity and R\&D”, paper presented to the OECD Working Party on Statistics, Special Session on Globalisation, Paris, 18-19 November.

Swaim, P. and R.-L. Tejada (2005), "Trade Adjustment Costs in OECD Labour Markets: How Big is the Problem and How Should Policy Makers Respond to It? ”, OECD, Directorate of Employment, Labour and Social Affairs, unpublished paper.

Van Welsum, D. and Vickery, G. (2005), "Potential Offshoring of ICT-Intensive Using Occupations", OECD DSTI Information Economy Working Paper, forthcoming, Paris.

Van Ark, B., R. Inklaar and M. Timmer (2004), "Productivity Differentials in the U.S. and E.U. Distributive Trade Sector: Statistical Myth or Reality", paper presented to an OECD Workshop on services, Paris, 15-16 November 2004.

Van Ark, B., R. Inklaar and R.H. McGuckin (2003), "Changing Gear: Productivity, ICT and Service Industries in Europe and the United States", in J.F. Christensen and P. Maskell (eds.), The industrial Dynamics of the New Digital Economy, Edward Elgar.

Van Ommeren, M. and J. Leuvensteijn (2003), "Do Transaction Costs Impede Mobility in the Netherlands?", CPB Notes, www.cpb.nl/nl/cpbreport/2003_1/s3_1.pdf

Vignoles, A., F. Galindo-Rueda and L. Feinstein (2004), "The Labour Market Impact of Adult Education and Training: A Cohort Analysis", Scottish Journal of Political Economy, Vol. 51, No. 2.

Wölfl, A. (2003), "Productivity Growth in Service Industries: An Assessment of Recent Patterns and the Role of Measurement", OECD STI Working Paper, No. 2003/7.

Wölfl, A. (2005), "The Service Economy in OECD Countries", OECD STI Working Paper, No. 2005/3. 


\section{WORKING PAPERS}

The full series of Economics Department Working Papers can be consulted at www.oecd.org/eco/Working_Papers/

426. Product Market Competition and Economic Performance in Iceland (April 2005) Thomas Laubach and Michael Wise

425. Enhancing Brazil's Regulatory Framework for Network Industries: The Case of Electricity, Oil and Gas, and Water and Sanitation (April 2005) Edmar Almeida and Nanno Mulder

424. Education Attainment in Brazil: The Experience of FUNDEF (April 2005) Luiz de Mello and Mombert Hoppe

423. Estimating a Fiscal Reaction Function: The Case of Debt Sustainability in Brazil (April 2005) Luiz de Mello

422. Product Market Competition and Economic Performance in the Netherlands (April 2005) Maria Maher and Michael Wise

421. Product Market Competition and Economic Performance in Canada (April 2005) Maria Maher and Jay Shaffer

420. The Impact of Ageing on Demand, Factor Markets and Growth (April 2005) Joaquim Oliveira Martins, Frédéric Gonand, Pablo Antolin, Christine de la Maisonneuve and Kwang-Yeol Yoo.

419. Product Market Regulation in OECD Countries: 1998 to 2003

(February 2005) Paul Conway, Véronique Janod and Giuseppe Nicoletti

418. Reforming Turkey's Public Expenditure Management (February 2005) Rauf Gönenç, Willi Leibfritz and Erdal Yilmaz

417. Fiscal Gimmickry in Europe: One-Off Measures and Creative Accounting (February 2005) Vincent Koen and Paul van den Noord

416. Getting the Most out of Public Sector Decentralisation in Japan (January 2005) Isabelle Joumard and Tadashi Yokoyama

415. Structural Policy Reforms and External Imbalances (January 2005) Mike Kennedy and Torsten Sløk

414. The Jobs Challenge in Poland: Policies to Raise Employment (January 2005) Andrew Burns and Przemyslaw Kowalski

413. Product Market Competition and Economic Performance in Finland (December 2004) Jens Høj and Michael Wise

412. Oil Price Developments: Drivers, Economic Consequences and Policy Responses (December 2004) Anne-Marie Brook, Robert Price, Douglas Sutherland, Niels Westerlund and Christophe André

411. Wealth Effects on Money Demand in EMU: Econometric Evidence (November 2004) Laurence Boone, Fanny Mikol and Paul van den Noord

410. Banking Reform in Russia : Problems and Prospects

(November 2004) William Tompson 


\section{ECO/WKP(2005)14}

409. Public Expenditure in France

(November 2004) Andrew Burns and Alessandro Goglio

409 La gestion des dépenses publiques en France

(Novembre 2004) Andrew Burns et Alessandro Goglio

408. Russian Industrial Restructuring: Trends in Productivity, Competitiveness and Comparative Advantage (October 2004) Rudiger Ahrend

407. Improving the Capacity to Innovate in Germany

(October 2004) Andrés Fuentes, Eckhard Wurzel and Margaret Morgan

406. Tax Treatment of Private Pension Savings in OECD Countries and the Net Tax Cost per Unit of Contribution to Tax-Favoured Schemes

(October 2004) Kwang-Yeol Yoo and Alain de Serres

405. The Reform of the Health Care System in Portugal (October 2004) Stéphanie Guichard

404. Accounting for Russia's Post-Crisis Growth (October 2004) Rudiger Ahrend

403. Restructuring Russia's Electricity Sector: Towards Effective Competition or Faux Liberalisation? (October 2004) William Tompson

402. Russia's Gas Sector: The Endless Wait for Reform? (September 2004) Rudiger Ahrend and William Tompson

401. One Money, One Cycle? Making Monetary Union a Smoother Ride (September 2004) Peter Hoeller, Claude Giorno and Christine de la Maisonneuve

400. Modelling Cyclical Divergence in the Euro Area: The Housing Channel (September 2004) Paul van den Noord

399. Product Market Competition and Economic Performance in Korea (August 2004) Yongchun Baek, Randall Jones and Michael Wise

398. Product Market Competition and Economic Performance in the United States (July 2004) Hannes Suppanz, Michael Wise and Michael Kiley

397. Saving Behaviour and the Effectiveness of Fiscal Policy (July 2004) Luiz de Mello, Per Mathis Kongsrud and Robert Price

396. The impact of exchange rate regimes on real exchange rates in South America, 1990-2002 (June 2004) Anne-Laure Baldi and Nanno Mulder

395. How Market Imperfections and Trade Barriers Shape Specialisation: South America vs. OECD (June 2004) Joaquim Oliveira Martins and Tristan Price

394. Housing Markets, Wealth and the Business Cycle (June 2004) Pietro Catte, Nathalie Girouard, Robert Price and Christophe André

393. Long-Term Budgetary Implications of Tax-Favoured Retirement Saving Plans (June 2004) Pablo Antolin, Alain de Serres and Christine de la Maisonneuve

392. Enhancing Income Convergence in Central Europe after EU Accession (June 2004) Patrick Lenain and Lukasz Rawdanowicz 